\title{
Visual outcome and patient satisfaction after corneal and refractive surgery
}

Citation for published version (APA):

Tahzib, N. G. (2008). Visual outcome and patient satisfaction after corneal and refractive surgery.

[Doctoral Thesis, Maastricht University]. Datawyse / Universitaire Pers Maastricht.

https://doi.org/10.26481/dis.20081010nt

Document status and date:

Published: 01/01/2008

DOI:

10.26481/dis.20081010nt

Document Version:

Publisher's PDF, also known as Version of record

\section{Please check the document version of this publication:}

- A submitted manuscript is the version of the article upon submission and before peer-review. There can be important differences between the submitted version and the official published version of record.

People interested in the research are advised to contact the author for the final version of the publication, or visit the DOI to the publisher's website.

- The final author version and the galley proof are versions of the publication after peer review.

- The final published version features the final layout of the paper including the volume, issue and page numbers.

Link to publication

\footnotetext{
General rights rights.

- You may freely distribute the URL identifying the publication in the public portal. please follow below link for the End User Agreement:

www.umlib.nl/taverne-license

Take down policy

If you believe that this document breaches copyright please contact us at:

repository@maastrichtuniversity.nl

providing details and we will investigate your claim.
}

Copyright and moral rights for the publications made accessible in the public portal are retained by the authors and/or other copyright owners and it is a condition of accessing publications that users recognise and abide by the legal requirements associated with these

- Users may download and print one copy of any publication from the public portal for the purpose of private study or research.

- You may not further distribute the material or use it for any profit-making activity or commercial gain

If the publication is distributed under the terms of Article $25 \mathrm{fa}$ of the Dutch Copyright Act, indicated by the "Taverne" license above, 


\section{Visual outcome and patient satisfaction after corneal and refractive surgery}


(C) Copyright NG Tahzib, Maastricht 2008 ISBN: 9789052787510

Cover Design: M. Schreuder en N.G. Tahzib Layout: Datawyse Printed by Datawyse, Universitaire Pers Maastricht 


\title{
Visual outcome and patient satisfaction after corneal and refractive surgery
}

\author{
PROEFSCHRIFT \\ ter verkrijging van de graad van doctor aan de Universiteit \\ Maastricht, op gezag van de Rector Magnificus \\ Prof. Mr. G.P.M.F. Mols volgens het besluit van het College van \\ Decanen, in het openbaar te verdedigen op 10 oktober 2008 \\ om 12:00 uur \\ door \\ Nayyirih Grace Tahzib \\ geboren 31 oktober 1974 te Utrecht
}

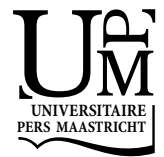




\section{Promotor}

Prof. dr. F. Hendrikse

\section{Copromotor}

Dr. R.M.M.A. Nuijts

\section{Beoordelingscommissie}

Prof. dr. B.W. van de Borne, voorzitter

Dr. C. Budo

Prof. dr. G.P.M. Luyten (Leiden Universitair Medisch Centrum)

Prof. dr. G. van Rij (Erasmus Medisch Centrum, Rotterdam)

Dr. C.A.B. Webers 


\section{CONTENTS}

Chapter 1

Introduction

Chapter 2

Comparison of two pupillometers in determining pupil size for refractive surgery

Bootsma SJ, Tahzib NG, Eggink FAGJ, de Brabander J, Nuijts RMMA.

Acta Ophthalmol Scand. 2007 May;85(3):324-8.

Chapter 3

71

Evaluation of pupil dynamics after implantation of Artisan phakic intraocular lenses

Bootsma SJ, Tahzib NG, Eggink FAGJ, Nuijts RMMA.

J Refract Surg. 2006 Apr;22(4):367-71.

\section{Chapter 4}

Functional outcome and patient satisfaction after laser in situ keratomileusis for correction of myopia Tahzib NG, Bootsma SJ, Eggink FA, Nabar VA, Nuijts RMMA. J Cataract Refract Surg. 2005;31:1943-1951.

\section{Chapter 5}

Functional outcome and patient satisfaction after Artisan phakic intraocular lens implantation for correction of myopia Tahzib NG, Eggink FAGJ, Nuijts RMMA. Am J Ophthalmol. $2006 \mathrm{Jul} ; 142(1): 31-39$.

\section{Chapter 6}

Artisan phakic intraocular lens implantation for correction of moderate to high myopia: 10-year follow-up results Tahzib NG, Nuijts RMMA, Wu WY, Budo CJ. Ophthalmology. 2007 Jun;114(6):1133-42.

\section{Chapter 7}

Three year follow-up analysis of Artisan toric lens implantation for correction of postkeratoplasty ametropia in phakic and pseudophakic eyes

Tahzib NG, Cheng YYY, Nuijts RMMA.

Ophthalmology. 2006 Jun;113(6):976-84. 
Artisan toric aphakic intraocular lens implantation for the correction of severe astigmatism after radial keratotomy Tahzib NG, Eggink FAGJ, Odenthal MTP, Nuijts RMMA. J Cataract Refract Surg. 2007 Mar;33(3):531-5.

\section{Chapter 9}

Recurrent intraocular inflammation after Artiflex phakic intraocular lens implantation for the correction of high myopia Tahzib NG, Eggink FAGJ, Frederik PM, Nuijts RMMA. J Cataract Refract Surg. 2006 Aug;32(8):1388-91.

Chapter 10

Higher order aberrations in iris-fixated rigid and foldable phakic intraocular lenses

Tahzib NG, MacRae SM, Yoon G, Berendschot TTJM, Eggink FAGJ, Hendrikse F, Nuijts RMMA.

$J$ Cataract Refract Surg. In Press.

Chapter 11

General Discussion

Summary

Samenvatting 
Introduction 


\section{INTRODUCTION}

The field of corneal and refractive surgery offers the patient the possibility of becoming independent of spectacles and/or contact lenses. The attainment of this treatment goal is of particular importance to individuals who are restricted in their professional and social life by their contact lens or spectacle intolerance.

The developments and outcome of refractive surgery have received increasing attention in the medical literature and public media, a phenomenon which is mainly related to the numerous success stories and the dramatic changes achieved by correction of the refractive error and the resultant independence of spectacles and contact lenses.

Numerous corneal and refractive surgery techniques have become available for the correction of the refractive error, with the majority of treatments consisting of myopic and myopic-astigmatic corrections. Since the start of excimer laser treatments and surgical implantations of phakic anterior chamber lenses, the field of corneal and refractive surgery has greatly evolved. Refractive surgery techniques have been refined and continually evolving to be more specifically geared towards the individual optical design, which can differ greatly between individuals and depends on various factors, such as the amount of the refractive error and the degree of optical aberrations. In addition, treatments are being refined to more adequately meet the specific aims of the individual patient seeking treatment. Laser ablation techniques have changed from the standard correction of the refractive error to personalized and optimized laser treatments and from broad-beam to scanning-spot or flying-spot devices. These days, the choice of anterior chamber intraocular lenses (IOL) include a range of various phakic lenses, including toric phakic IOLs and foldable phakic IOLs. The role of the appropriate optical zone size in laser ablation treatment, the relevance of pupil size and optical aberrations continue to play an important part in the selection of refractive surgery candidates.

Despite the instant success stories related to the dramatic changes in the refractive error, numerous studies on the initial outcome demonstrated a decreased quality of vision, which may be attributed to contrast sensitivity loss and subsequent optical side effects, such as night vision complaints, glare and halos. The evaluation of patient satisfaction is of paramount importance in the full assessment of corneal and refractive surgery outcome and is gradually receiving a central role in relation to the pre- and postoperative evaluation of the refractive surgery patient. This trend can be seen from the growing amount of medical reports, starting some 25 years ago and vastly increasing throughout the last decade. The main questions related to patient satisfaction are: Is the patient happy with the outcome? Was the goal of treatment reached? Does the clinical outcome correlate with the subjective result? The necessity for a more precise assessment of 
subjective quality of vision and patient satisfaction after refractive surgery has increased with the discovery of several optical side effects, namely night vision complaints, glare and halos. The exact nature of these optical side effects remains difficult and sometimes faces us with challenges and limitations concerning the full attainment of a satisfying refractive and patient outcome. However, optical side effects are also known to decrease within the first 6 months after treatment, which might be the result of a gradual (neural) adaptation to a new condition. This is confirmed by the finding that the majority of patients are very happy with their outcome and would choose the same surgical treatment again, if they had to do it all over again.

Patient questionnaires can assist in the evaluation of patient satisfaction and will continue to play a central role when selecting refractive surgery candidates. It is of vital importance that the eye surgeon adequately assesses the specific needs of the patient, makes a full objective evaluation of the patients' eye and then decides whether or not this individual can be helped by the correction of their refractive error through a surgical intervention.

Various types of questionnaires may then assist in evaluating the outcome of treatment.

\section{Aim and outline of the thesis}

The aims of this thesis are to study the visual outcome and patient satisfaction of various refractive surgery techniques for the correction of the refractive error and to evaluate the significance of various clinical parameters on the selection of refractive surgery candidates.

Chapter 1 is a literature review which discusses the background of the various refractive surgery devices and techniques. It summarizes the available literature on patient satisfaction and questionnaires, including subjective and objective quality of vision. The clinical outcome and potential benefits and drawbacks of various laser refractive techniques, phakic IOL implantations and visual rehabilitation modalities after penetrating keratoplasty are also discussed.

Chapters 2 and 3 describe the role of specifically designed instruments to determine pupil size for refractive surgery and evaluate the effect of iris-fixated phakic IOLs on pupil dynamics and the potential consequences for decision taking in selecting patients for refractive surgery.

Chapter 4 discusses visual outcome and patient satisfaction after laser in situ keratomileusis for the correction of myopia. 
Chapters 5 and 6 discuss the results after Artisan phakic IOL implantation for the correction of myopia. Chapter 5 reports the functional outcome and patient satisfaction after 1 year and chapter 6 reports the results after 10 years.

Chapters 7 and 8 discuss the application of the Artisan toric IOL in patients with aberrations in the corneal shape after corneal transplantation surgery and corneal refractive surgery. Chapter 7 demonstrates a 3-year follow-up analysis of Artisan toric IOL implantation for the correction of post-keratoplasty ametropia in phakic and pseudophakic eyes. Chapter 8 describes 2 case reports of Artisan toric aphakic IOL lens implantation for the correction of severe astigmatism after radial keratotomy.

In chapter 9 a complication and the consequences for the individual patient of implantation of a foldable phakic IOL are described.

Chapters 10 compares in vitro and in vivo differences between a non-foldable polymethyl methacrylate phakic IOL and a recently developed foldable phakic IOL and analyses changes in optical aberrations for the correction of myopia.

\section{PATIENT SATISFACTION}

How can we measure subjective and objective quality of refractive surgery?

With the increasing amounts of new and improved keratorefractive surgery treatments for the correction of the refractive error, the importance of systematic evaluation of the treatment outcome has grown. Until recently, the evaluation and comparison of refractive surgery techniques were mainly focused on the objective, clinical outcome such as the subjective and objective refraction, uncorrected and best-corrected visual acuity (UCVA and BCVA; efficacy), refraction within 1 diopter (D) of the targeted correction (predictability) and the number of Snellen acuity lines lost or gained after the procedure (safety). Formats for reporting these parameters have been suggested in the literature. ${ }^{1,2}$

Patient satisfaction after refractive surgery, however, entails the greater area of quality of life and functional status as self-perceived by the patient. The area of measuring patient satisfaction is complex and multidimensional, since it is influenced by the combination of subjective quality of vision, personal expectations and personality type. ${ }^{3,4}$ It is important that refractive surgeons understand patient motivations for seeking surgery, since this can influence their postoperative satisfaction. 


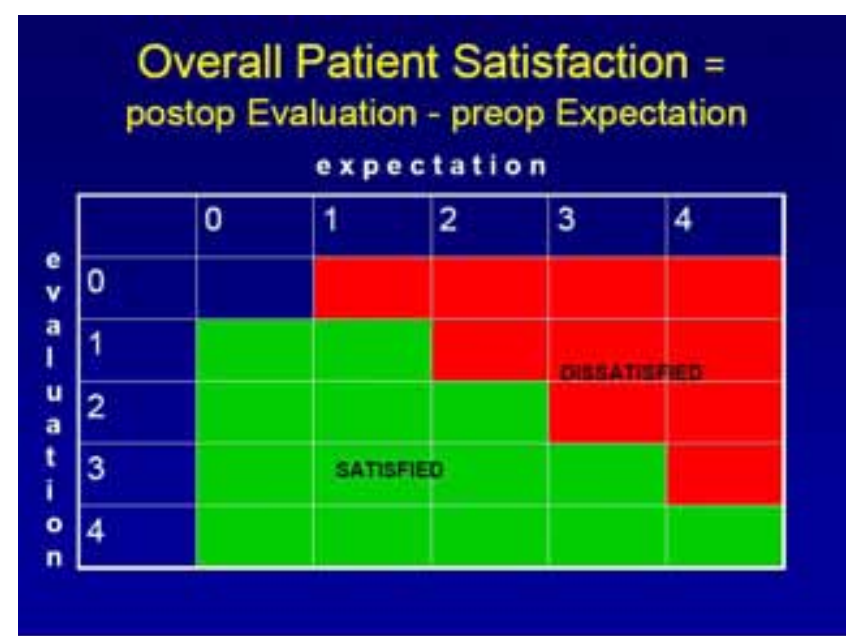

Figure 1. The 'disconformation-of-expectations' model

In order to predict the unhappy patient it is important to:

1. Identify what the expectations and motivations of patients are before undergoing refractive surgery;

2. Describe the population of satisfied and dissatisfied patients;

3. Identify parameters responsible for patient dissatisfaction.

Patient satisfaction can be defined by the difference between the patient's expectation before surgery and the outcome after surgery. An example is the 'disconformation-of-expectations' model (Fig. 1), which explains that if perceived performance is evaluated as worse than the expectation, negative disconfirmation results in dissatisfaction. ${ }^{5,6}$ This model closely adheres to the current theory of "undersell and overdeliver" to achieve satisfied patients in corneal and lenticular refractive surgery.

The importance of consumer satisfaction can also be found in the world of marketing, where firms are advised to develop specified definitions of consumer satisfaction, which will guide the assessment of satisfaction. This measurement process seems to be necessary to move closer to truly understanding customers and to make better managerial decisions. ${ }^{7}$

\section{Patient satisfaction questionnaires}

One of the most effective and efficient ways to study patient expectations and motivations is by using validated questionnaires, which systematically ask patients about their experiences. ${ }^{4,}$ 8-22 Self-administered questionnaires, rather than physician-administered questionnaires, enable a more objective view of patient satisfaction and quality of vision. When a test is administered by a physician, results may be biased and patients might feel compelled to always answer in the 
affirmative. Several studies have used questionnaires for the assessment of patient expectations and satisfaction. Realistic preoperative patient expectations seem to correlate well with postoperative patient satisfaction, meaning that a good understanding of patient motivation for seeking refractive surgery is important. ${ }^{12}$ Primary reasons for seeking refractive surgery such as laser in situ keratomileusis (LASIK) are a desire for freedom from spectacles or contact lenses (32.1\%) and spectacle or contact lens intolerance $(30.4 \%) .{ }^{23,24}$

The questionnaire which we used in our studies is a psychometric instrument that was developed and validated by Brunette et al. and has been previously used for the evaluation of patient satisfaction after photorefractive keratectomy (PRK) and to assess postoperative visual symptoms. ${ }^{9}, 10$ The questionnaire was translated into the Dutch language from the original English. For analysis purposes, the 66 items of the questionnaire were grouped in seven distinct scales which were selfadministered by patients. Scale scores increased with satisfaction, ranging from 1 (very dissatisfied) to 5 (very satisfied). Each of the seven scales covered a specific aspect of quality of vision, including global satisfaction, quality of uncorrected and corrected vision, quality of night vision, glare, daytime driving and night driving.

Several other patient satisfaction questionnaires have been developed in order to assess subjective visual disability and self-rated quality of vision in patients with ocular disease:

The QUOTE Cataract Questionnaire was developed at our institution to measure quality of care from the perspective of cataract patients. The acronym QUOTE stands for "quality of care through the patients' eyes". The questionnaire was developed as a self-administered measure using both qualitative and quantitative research methods. QUOTE questionnaires can be used in quality-assessment studies to evaluate the quality of health care services from the patients' perspective in a very general way. They can also be used in studies whose aim is quality improvement at the level of specific quality aspects. ${ }^{18}$

The Refractive Status and Vision Profile (RSVP) is a questionnaire that consists of eight scales, designed to measure self-reported functioning, symptoms, health perceptions, and expectations in individuals with refractive error. ${ }^{19}$

The VF-14 questionnaire, developed by the Cataract PORT group, has proven test-retest reliability, responsiveness, and international validity in cataract patients specifically. The questionnaire evaluates functional status related to vision and can detect clinically meaningful changes following cataract surgery and provide information related to the outcome of surgery. ${ }^{4,20-22}$

The National Eye Institute-Refractive Error Quality of Life survey (NEI-RQL) includes 13 scales which are designed to assess the impact of refractive error and its correction on daily life. The scales are clarity of vision, expectations, near vision, far vision, diurnal fluctuations, activity limitations, glare, symptoms, 
dependence on correction, worry, suboptimal correction, appearance, and satisfaction with correction. The NEI-RQL questionnaire appears to be useful for comparisons of various surgical and non-surgical methods for the correction of the refractive error. ${ }^{11,16,17}$

\section{OUTCOMES OF CORNEAL REFRACTIVE SURGERY}

Over the years, surgical procedures for the correction of moderate to severe myopia have been developed. These procedures can either involve the cornea (corneal refractive surgery) or the lens (lenticular refractive surgery).

\section{Corneal refractive surgery procedures for treatment of myopia}

Radial keratotomy (RK)

Before the popularity of excimer photoablative refractive surgery, the technique of RK (popularized by Fyodorov) ${ }^{25}$ was among the most widely used surgical techniques for the correction of myopia, being a popular procedure during the eighties and early nineties, especially in Russia and the United States and to a lesser extent in Europe. ${ }^{26-28}$ The method of RK consists of making deep radial incisions in the paracentral and peripheral anterior cornea using a diamond blade knife. The technique results in flattening of the central corneal curvature and steepening of the peripheral area, which reduces the degree of myopia.

The number of RK incisions, diameter of the optic zone and patient age determine the refractive outcome after RK. Incision direction was shown to be another predictor, with the centripetal (versus the centrifugal) incision decreasing myopia to a higher degree.

Although the treatment by RK initially resulted in satisfactory refractive results, it appeared not to be as predictable as current refractive surgery techniques. One common and challenging side effect of RK was the development of secondary and continuing hyperopia. Clinical studies have shown that hyperopic shift after RK occurred with a frequency of $17 \%$ to $43 \%$, with an additional incidence of $1 \%$ to $2 \%$ each year. ${ }^{29-31}$ The Prospective Evaluation of Radial Keratotomy study was a 9-center clinical trial which analyzed the long-term (10-year) effects and stability of myopic RK (with a range of -2.00 to $-8.75 \mathrm{D}$ ). ${ }^{29}$ They showed that $53 \%$ of eyes achieved an UCVA $\geq 20 / 20$, and $85 \% \geq 20 / 40$. They also showed that $38 \%$ of eyes achieved a refraction $\pm 0.50 \mathrm{D}$ and $60 \% \pm 1.0 \mathrm{D}$. Most importantly, they observed a progressive hyperopic shift up to 10 years after RK. This was also shown in another 10-year report, but they suggested that the refractive and acuity changes were mainly normal physiologic changes. ${ }^{32}$ Finally, a different retrospective 10 -year RK study did not observe any significant refractive changes. ${ }^{33}$ 
A less common side effect after RK is the development of irregular astigmatism, which can be induced by the intersection of the incisions with the visual axis or by the eccentricity of the optical zone. ${ }^{34}$ Some other side effects are fluctuating vision and glare. ${ }^{29,35,36}$

Aside from treating myopia, RK has also been used for the correction of astigmatism (also known as arcuate keratotomy), although the predictability of this technique is known to be slightly less than that for correction of myopia. The procedure has been shown to be an effective and safe method for correcting moderate to severe naturally occurring astigmatism. ${ }^{37-40}$

The popularity of RK declined since the approval of the excimer laser in 1995, due to the superior outcomes of PRK and LASIK.

\section{Photorefractive keratectomy (PRK)}

In the late 1980s, the technique of laser and tissue interaction was first described by Trokel and Srinivasan and one of the first clinical results were demonstrated by Seiler et al. ${ }^{41,42}$ They proved that the far-ultraviolet (193-nm) argon fluoride excimer laser could be used for the permanent removal of corneal stromal tissue in a precise manner, with minimal damage to the adjacent corneal tissue. PRK became widely available for the correction of myopia in the early 1990s.

In the early days, PRK was the main treatment for low to moderate myopia. The technique underwent various developments, varying from laser systems, treatment algorithms to the choice of transition and ablation zones. In PRK, before the laser ablation occurs, the corneal epithelium is removed, either manually with a blade or a rotating brush or after alcohol administration.

Short-term problems after PRK are discomfort in the first 24 hours; a delay in visual recovery lasting 3 to 5 days during epithelial healing; and haze lasting weeks to months after the procedure. Previous studies with 1.5 to 6-year followup demonstrated that PRK ablations often show an immediate postoperative hyperopic shift, due to a thinner epithelium. ${ }^{43-46}$ The hyperopic shift is often compensated by a period of regression that stabilizes between 1 and 6 months. Refractive stability after PRK is generally achieved after 6 months to 1 year and maintained for up to a period of 5 years.

Long-term studies on the outcome of PRK found no evidence of progressive time-dependent hyperopic shift or late regression, with trace haze in $0 \%$ to $17.2 \%$ after 12 years. They concluded that corneal haze was transient and generally resolved by 1 year. Finally, they suggested that chronic stromal remodeling and corneal ectasia are unlikely events after PRK. ${ }^{47,48}$

In summary, for treatment of patients with low-to-moderate myopia, PRK has shown to produce stable and predictable results with an excellent safety profile. 
Laser in situ keratomileusis (LASIK)

Barraquer was one of the leaders in the development of the use of lamellar refractive surgery to correct refractive errors by myopic keratomileusis, in which a lenticule was excised from the cornea with a microkeratome and its refractive power was altered by cutting in a cryolathe using freezing techniques. He first described the technique in 1965 and presented the initial clinical results in 1981.49,50 In 1991, Pallikaris first reported on the results of LASIK, which meant a major change in the field of refractive surgery. ${ }^{51}$ The side effects associated with PRK made LASIK treatment to be the leading procedure in refractive surgery. ${ }^{52}$ The popularity of LASIK is probably related to the relatively fast visual recovery time, minimal discomfort immediately after treatment and the minimal incidence of haze. For low to moderate myopia, LASIK has proven to be very effective, predictable and safe, achieving an UCVA of $20 / 40$ or more in $82 \%-100 \%$ of eyes and an UCVA of 20/20 in 54\%-93.9\% of eyes. The technique has shown to achieve a very accurate correction, with $72 \%-96.1 \%$ of eyes achieving a refractive error within $\pm 0.50 \mathrm{D}$ of the intended correction and $87.9 \%-100 \%$ of eyes within $\pm 1.00 \mathrm{D}$ of the intended correction. ${ }^{12,52-70}$ For moderate to high myopia (>-6.0 D), the results show more variation. ${ }^{53,59,68,70-77}$ (Tables 1 and 2)

PRK and LASIK candidates typically have healthy eyes; thus, achieving and maintaining high levels of (subjective) satisfaction after surgery are important. Reports show that patient satisfaction after LASIK seems to range between $82 \%$ and $98 \% .8,12,72,78$ Patients are generally very satisfied with their uncorrected vision, visual recovery and quality of life after LASIK treatment, with the majority of patients reporting that they would have the surgery again (up to $98 \%$ ) and/or recommend the procedure to a friend up to (97\%). $8,12,14,71$, 74, 79

Myopic regression is a condition that can occur after LASIK. The risk of myopic regression increases with the degree of preoperative myopia and patient age. Long-term studies on LASIK for treatment of moderate and extreme myopia showed a trend towards myopic regression, changing from 52\%-96\% of eyes within $\pm 1.0 \mathrm{D}$ of the attempted correction after 1 year to $46 \%-91 \%$ after 5 to 6 years follow-up. ${ }^{57,71,80}$ In contrast, LASIK studies with lower degrees of preoperative myopia $(<-6.0 \mathrm{D})$ have reported refractive stability achieved at 3 to 6 months and sustained to 2 years. ${ }^{55,81}$

Benefits of LASIK as opposed to PRK are diminished discomfort and haze, thus leading to a more rapid visual rehabilitation. ${ }^{52,55}$ 


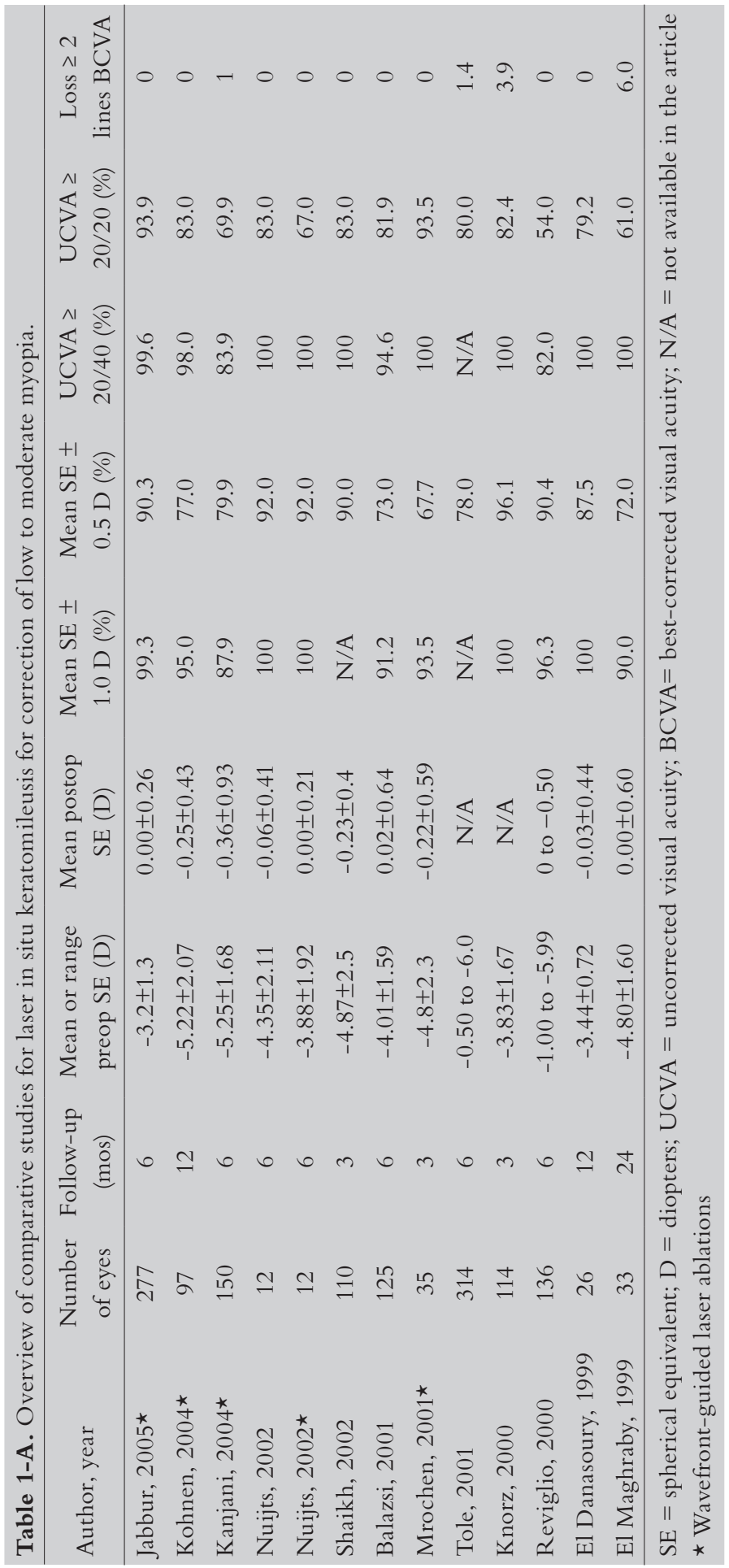




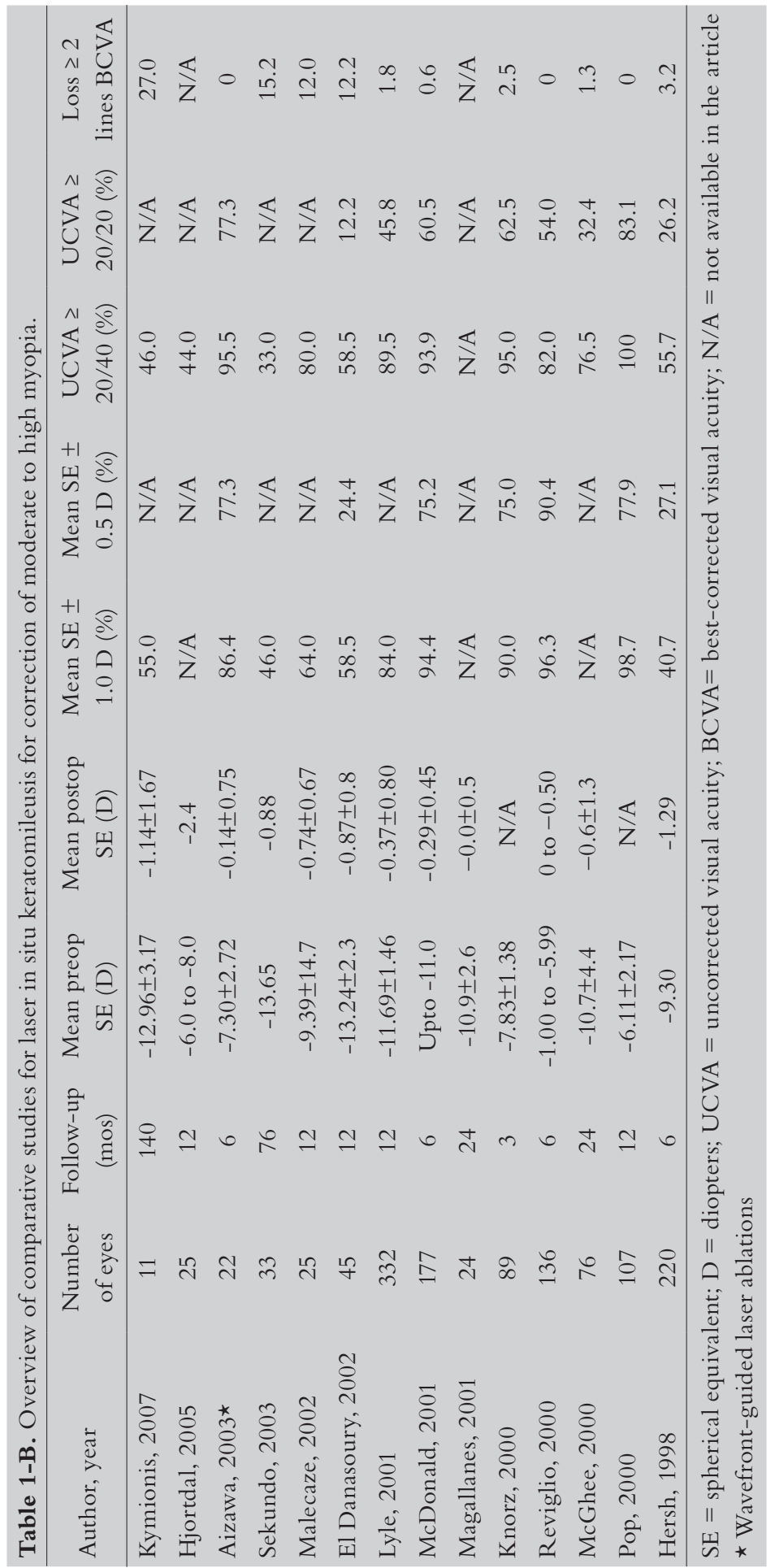


Table 2. Reported factors leading to vision disturbances. ${ }^{8,14,150,156,157}$

\begin{tabular}{lccc}
\hline Factors & $\mathrm{RK}$ & PRK/LASEK & LASIK \\
\hline Large scotopic pupil size & $\mathrm{X}$ & $\mathrm{X}$ & $\mathrm{X}$ \\
Small optical clear zone & $\mathrm{X}$ & $\mathrm{X}$ & $\mathrm{X}$ \\
Haze & & $\mathrm{X}$ & \\
Flap complications & $\mathrm{X}$ & $\mathrm{X}$ \\
Variable corneal steepening & & $\mathrm{X}$ & $\mathrm{X}$ \\
Ectasia & $\mathrm{X}$ & $\mathrm{X}$ \\
Epithelial ingrowth & $\mathrm{X}$ & $\mathrm{X}$ & \\
Extensive scarring & $\mathrm{X}$ & $\mathrm{X}$ & $\mathrm{X}$ \\
Irregular astigmatism & & $\mathrm{X}$ & $\mathrm{X}$ \\
Small ablation diameter & & $\mathrm{X}$ & $\mathrm{X}$ \\
Decentration of ablation zone & & & \\
RK=Radial keratotomy; PRK=Photorefractive keratectomy; LASEK=Laser-assisted sub- \\
epithelial keratectomy; LASIK=Laser in situ keratomileusis.
\end{tabular}

\section{Risks of LASIK}

Although the risks associated with LASIK are considered to be low, intra-operative and postoperative flap-related complications are sight-threatening and have resulted in a permanent loss of BCVA. The overall incidence of intra-operative LASIK flap complications (such as incomplete flaps, buttonholes, free caps, torn flaps) ranges from $0.3 \%$ to $5.7 \% .^{82-100}$

\section{Ectasia post-LASIK}

Another rare, but important complication that can occur after LASIK is postoperative corneal ectasia. The occurrence of iatrogenic keratectasia was first described by Seiler et al, who recommended a residual corneal thickness of the stromal bed of at least 250 microns, based on biochemical considerations. ${ }^{101}$ The ectasia seems to be related to biomechanical changes in the cornea after treatment. Previous

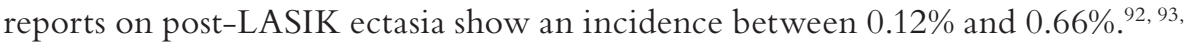
${ }^{102} \mathrm{R}$ isk factors that might contribute to the development of ectasia after LASIK have been suggested to be: high intraocular pressure, irregular topography, thin corneas, thin remaining corneal beds, forme fruste keratoconus, thick corneal flaps, large optical zones, and possible high myopia. $77,92,94-97,101-115$

In summary, LASIK has shown to be effective, predictable and safe, with the advantages of rapid visual recovery and minimal discomfort. Since its advent, LASIK has become the most widely performed refractive surgery technique, with high patient satisfaction. 
Laser-assisted subepithelial keratectomy (LASEK)

LASEK was introduced independently in 1999, ${ }^{116,117}$ and described by several investigators after that. ${ }^{118-122}$ The aim of LASEK is to preserve the original anatomy of the cornea and to avoid potential risks posed by the creation of a LASIK flap. The treatment is in fact a blend of PRK and LASIK, aiming to decrease the potential complications of the two treatments. It avoids the flaprelated complications and reduces the risk of keratectasia associated with LASIK. LASEK does not use a microkeratome to create a stromal flap. In LASEK treatment, diluted ethanol solution is applied to loosen the corneal epithelium, after which the epithelium is partially removed from Bowman's layer, connected only at a hinge. Laser treatment is applied directly to Bowman's layer, and the epithelium is replaced and covered by a bandage contact lens.

One of the main therapeutic advantages of LASEK is that it can be performed in cases in which LASIK may be contraindicated. These include eyes with thin, steep, and flat corneas; epithelial basement membrane dystrophy; large pupils (requiring wider and therefore deeper ablations); higher myopia; deep-set eyes or tight orbits.

Reports have shown that LASEK is a safe, effective and predictable treatment, which can be seen as a good alternative to LASIK for the surgical correction of myopia. These studies showed that $91 \%-94 \%$ of eyes achieved an UCVA $\geq 20 / 40$ and $73 \%-91 \%$ an UCVA of $\geq 20 / 20$. After 2 years follow-up, $62 \%-65.9 \%$ of eyes achieved a refraction within $\pm 0.5 \mathrm{D}$ of the desired refraction and $92 \%-100 \%$ of eyes \pm 1.0 D. Loss of 1 or more lines of BCVA was demonstrated in $14.4 \%-16.3 \%$ of eyes after 1 year follow-up. ${ }^{123-137}$ Comparing LASEK with PRK and LASIK, it has been indicated that the recovery period after LASEK is shorter than after PRK ${ }^{128}$, but might be somewhat slower than after LASIK. Discomfort after LASEK seems to be less than after PRK, which is probably related to the fact that the epithelial flap acts as a biological therapeutic lens that protects the ablated stroma. ${ }^{131}$

Previous reports have shown various incidences of corneal haze after LASEK. ${ }^{24}$, 125, 132, 133, 138, 139 LASEK can be combined with the use of mitomycin-C (MMC), a cytostatic drug known to inhibit proliferating cells and can be used to prevent post-ablation corneal haze in high risk cases. ${ }^{140,141}$ Various studies have shown the clinical use of MMC in other refractive surgery procedures. ${ }^{142-145}$

\section{Epithelial laser in situ keratomileusis (epi-LASIK)}

Epi-LASIK uses a modified microkeratome (epikeratome) to create a thin corneal epithelium flap before surface ablation. The difference between epi-LASIK and LASEK is that the separation of the epithelium is obtained mechanically without alcohol. Epi-LASIK has been proposed as a safe alternative to LASIK and is espe- 
cially suitable for patients with low to moderate myopia and myopic astigmatism, thin corneas, and in individuals with steeper or flatter corneas, where the cutting of a LASIK flap could potentially impose flap-related complications. The healing period and visual recovery tends to be slower than traditional LASIK. ${ }^{146-148}$ Postoperative discomfort usually occurs within the first 48 hours after surgery. A recent study by Pallikaris et al presented the preliminary results of epi-LASIK and stated that this technique is a safe and efficient method for the correction of low myopia, demonstrating that after 3 months follow-up, more than $96 \%$ of 44 treated eyes reach an UCVA of 20/40 or better and 92\% an UCVA of 20/25 or better. All the treated eyes were within $\pm 0.50 \mathrm{D}$ between 1 and 3 months after the procedure. ${ }^{147}$

In comparison with LASEK, it has been suggested that the incidence of haze after ablation of the cornea is less with epi-LASIK. Pallikaris showed that after 3 months follow-up, 56\% of eyes had clear corneas, $41 \%$ had trace haze and $3 \%$ had mild amounts of corneal haze. ${ }^{147}$

Longer-term clinical studies will be needed to confirm these preliminary results on epi-LASIK.

\section{GENERAL SIDE EFFECTS OF LASER REFRACTIVE SURGERY}

Although the many developments in keratorefractive surgery techniques have improved the clinical outcome and shown great success rates, several quality of vision problems have been reported. Qualitative visual disturbances can affect patients' daily activities and include subjective complaints such as glare, halos and difficulty with night driving. These problems have been reported in several clinical studies after refractive surgery, ranging from $12 \%$ to $57 \%$ in patients. 10, 14, 149-151 They are known to often diminish after the first six postoperative months. ${ }^{13-15,36,58,79,150,152-155}$ Glare, halos and night vision complaints (NVC) are among the primary complaints that have been reported by patients, which may be attributed to a loss of contrast sensitivity or low-contrast visual acuity. These complaints have been described after all refractive surgery techniques, varying in degree of incidence. ${ }^{36}$ After RK, the reported incidence of moderate to severe glare disability in the first 3 to 6 months ranges from $50 \%$ to $60 \%$, diminishing to $0-5 \%$ after 1 year and even further after 2 years. ${ }^{36}$

\section{Risk factors for night vision complaints after laser refractive surgery}

Reports on patient satisfaction after LASIK treatment ${ }^{8,13,150}$ showed that predictors for NVC can be:

1. Preoperative level of myopia (more than $5 \mathrm{D}$ )

2. Preoperative uncorrected visual acuity

3. Preoperative contrast sensitivity levels 
4. Increasing age

5. A flatter preoperative corneal curvature

6. Surgical enhancements

7. Optical zones smaller than $6 \mathrm{~mm}$

8. Postoperative residual refractive error higher than $0.5 \mathrm{D}$ from emmetropia

9. Postoperative residual cylinder.

Remarkably, pupil size was not shown to be a significant predictor of NVC in any of these studies. There is variable evidence in the literature on excluding patients with large pupils. ${ }^{8,14,150,156}$ It has been suggested in the past that a large pupil in combination with a small optical zone is a dominant factor leading to increased NVC, but other recent data show that the correlation between pupil size and NVC or between NVC and the pupil-optical zone disparity is much less critical than previously thought. ${ }^{8,10,13,36,150,154,155}$ Pupil size seems to indeed be a significant predictor of glare and halos after LASIK, especially in the first postoperative month, yet it was demonstrated that pupil size is not a significant variable 6 or 12 months after treatment. ${ }^{13,158}$ Postoperative remodeling of the corneal shape by the epithelium may be responsible for these findings.

Other postoperative reasons for dissatisfaction after laser refractive surgery

Common subjective complaints after refractive surgery in dissatisfied patients are blurred distance vision (59\%) and glare and night-vision disturbances (44\%). ${ }^{8}, 14,76$, 85, 150, 159 Common complications are under- and overcorrection (30\%), irregular astigmatism (30\%), dry eyes (4\% to $30 \%$ ), glare (up to $48 \%$ ) and difficulty with night driving (17\%)..$^{74,76,82,85,86,159}$ Common recommendations for management are non-surgical treatments $(68 \%)$ consisting primarily of medication (e.g. miotics) and rigid gas permeable (RGP) contact lenses. ${ }^{85}$, 159-161

\section{WAVEFRONT AND LASER REFRACTIVE SURGERY}

In 2000, the first results of wavefront-guided laser ablation were demonstrated. ${ }^{162}$ Higher order aberrations (HOA) can cause glare and halos and lead to decreased quality of vision. Wavefront technology was developed to categorize and limit the amount of HOA induced by refractive surgery. ${ }^{163}$ Customized corneal ablation combines wavefront sensing and wavefront correction. The wavefront sensor measures defocus, astigmatism and total and individual HOA. Defocus and astigmatism, also known as second-order aberrations, are the most important determinants of the refractive error. An older term for HOA is "irregular astigmatism", which can be somewhat misleading, since most of them have no relation to astigmatism. 
Over the last decade, several clinical reports have studied HOAs in refractive surgery patients, especially in LASIK studies. ${ }^{58,69,164-170}$ Some of these studies have shown an increase in patient satisfaction and reduced night vision complaints after wavefront-guided treatments. ${ }^{165,166,170-175}$ Reports studying changes in the HOA profile after laser refractive surgery suggest that, overall, spherical aberration is induced the most postoperatively, whereas the mean change in trefoil and coma tend to be the least. ${ }^{170,176,177}$

Current problems with wavefront-guided treatments are the lack of predictability for correcting the amount of HOA by the treatment. ${ }^{69,177,178}$ Several studies have indicated the advantages of wavefront-guided over conventional ablations in terms of decreased HOA and subjective complaints, but more and larger good randomized studies are needed to further analyze this. ${ }^{166,170,174,179}$ At the present time it is not very clear whether the excellent results are due to a better postoperative asphericity profile or a consequence of treating the preexistent HOAs.

HOA in symptomatic post-LASIK patients have been shown to be an average of 2.3 times greater in comparison to normal post-LASIK patients. ${ }^{174}$ Recent studies indicate that customized ablation based on corneal topography ("topographyguided ablation") is safe and effective, can lead to fewer NVC and less increase of HOA compared to conventional ablation. ${ }^{180-182}$

\section{Phakic IOLs}

For the past decade, laser refractive surgery techniques such as LASIK have been the preferred surgical procedure for most patients seeking independence of spectacles or contact lenses. For patients with high degrees of ametropia, LASIK is a less desirable procedure. For these patients, phakic IOLs represent a safe alternative for vision correction. Increasing amounts of refractive surgeons perform phakic IOL implantations. With the US Food and Drug Administration (FDA) approving the first phakic IOL in September 2004, the popularity of phakic IOLs has increased tremendously.

Compared to aphakic IOLs, phakic IOLs have a relatively smaller anatomic space in which they are implanted. Proper positioning, with adequate stability, must be achieved between the corneal endothelium and the anterior lens capsule. Over the last decade, there have been continuous improvements in IOL technology, microsurgical techniques, ocular viscosurgical devices, which have made these lenses to become an excellent alternative for the correction of moderate and high refractive errors with excellent levels of efficacy, predictability, and safety.

Phakic IOLs can be grouped into anterior chamber and posterior chamber lenses. Regardless of the location, accurate sizing and positioning are critical for a successful outcome. 
Anterior chamber phakic IOLs

The use of anterior chamber lenses was first described in 1954 and the 5-year results were presented by Barraquer in 1959. In 1975, the Dutchman Binkhorst was the first who described the optical design of anterior chamber IOL implants used in cataract surgery. The lens was studied by several authors. Anterior chamber phakic IOLs can be further grouped into angle-supported and irisfixated lenses.

\section{Angle-supported phakic IOLs}

Rigid anterior chamber angle-supported phakic IOLs were introduced in the 1950s. The first generation of these lenses lead to severe postoperative complications, such as corneal edema, chronic iritis, severe pupil ovalization and pupillary block glaucoma. These complications eventually lead to an abandonment of this first generation of lenses. A second generation of these lenses were reintroduced in the late 1980s by Baikoff. ${ }^{183}$ The results of this second generation of anglesupported lenses showed better visual and refractive outcomes and less postoperative complications, due to substantial improvements in design. ${ }^{183-193}$

Pupil ovalization is a known side-effect of this lens type, which may be caused by inadequate lens sizing (iris traction and consequent retraction). ${ }^{183,184,187,191-194}$ It has also been suggested to have an ischemic component, caused by compression of the iris vascularisation by the lens footplates and resulting in partial atrophy of the iris. ${ }^{187}$ This complication can lead to night glare and halos. The use of foldable lens models were expected to lead to a decrease in this complication. However, in 2007, the French government ordered a recall of 3 types of angle-supported, anterior chamber phakic IOLs, due to alarming concerns about excessive endothelial cell loss 2 to 3 years postoperatively as demonstrated by several cases of explantation of these lens models. The lenses removed from the market were Corneal's Icare and Ioltech/Zeiss Vivarte and NewLife phakic IOLs. The cause of the sudden drop in endothelial cells is not clear. Therefore, ophthalmologists have been strongly recommended caution when performing new phakic IOL implantations and closely monitor patients every 6 to 12 months. This recall will undoubtedly have an important impact on future developments in the field of anterior chamber phakic IOLs.

Coullet et al recently described 3 eyes in which a foldable angle-supported phakic IOL was implanted to correct high myopia, and in which rapid and severe postoperative endothelial cell loss occurred. In this article he attempted to illustrate the importance of accurate sizing of foldable angle-supported anterior chamber phakic IOLs to avoid excessive vaulting. ${ }^{195}$

Retinal complications can also occur, probably related to vitreous instability. One report showed a significant increase in the incidence of retinal detachment after implantation of this lens in eyes with an axial length larger than $30.4 \mathrm{~mm}{ }^{196}$ 
Iris-fixated phakic IOLs

The Artisan toric phakic IOL is composed of non-foldable, inert polymethyl methacrylate (PMMA), which is centered over the pupil with special haptics that are called "claws" which are fixed over the midperipheral iris. The lens was designed by Worst and Fechner in the late 1980s; and described by van der Heijde. It is a rigid lens with a fixed optical zone of 5 or $6 \mathrm{~mm}$, depending on the dioptric power of the lens. The lens has a convex-concave optic with a spherical anterior surface and a sphero-cylindrical posterior surface with a 5 -mm optical zone.

The short-term (up to 3 years) safety and efficacy of iris-fixated phakic IOLs have been demonstrated in many studies (Table 3). ${ }^{59,76,197-208}$ It has been stated that better UCVA, BCVA, contrast sensitivity, quality of vision, and exchangeability are the main advantages of Artisan lens implantation. ${ }^{59,76}$ This might be related to the fact that since the refractive power of phakic IOLs is not dependent on corneal wound healing, these lenses have the potential of offering a more accurate refractive correction than LASIK, especially in high myopes.

A toric version of the iris-fixated phakic IOL exists and can be used for the correction of astigmatism. Toric IOLs are available with the cylinder in line with the haptics or at an angle of $90^{\circ}$ with the haptics. ${ }^{209}$ An IOL with the cylinder in line with the haptics is recommended when the preoperative cylinder is between $0^{\circ}$ and $45^{\circ}$ or between $135^{\circ}$ and $180^{\circ}$. The toric phakic Artisan IOL is available in cylindrical powers up to $7.5 \mathrm{D}$. Recent results of the toric phakic Artisan IOL in eyes with myopia or hyperopia with astigmatism show that $63 \%$ to $73 \%$ of eyes reached $\pm 0.50 \mathrm{D}$ of the predicted refraction with a BCVA improvement in $65.7 \%$ to $70 \%$ of eyes. ${ }^{209-211}$

A foldable version of the spherical Artisan lens, the Artiflex iris-fixated phakic IOL, is a newer development in the area of lenticular refractive surgery for the correction of myopia and is currently being evaluated in a European multi-centre study. Important advantages of the foldable Artiflex lens over the PMMA Artisan lens are the smaller incision size of $3.4 \mathrm{~mm}$ (compared to the 5.5- to 6.5-mm incisions needed for the rigid model), which could reduce surgically induced astigmatism and may lead to a faster visual recovery period. Recent results on the Artiflex lens showed that $70 \%$ of eyes reached $\pm 1.0 \mathrm{D}$ of the targeted refraction, with $66 \%$ of eyes showing an improvement of $\geq 1$ BCVA lines. ${ }^{212}$ Another recent study comparing the Artiflex and the Artisan lens showed that $77.4 \%$ of Artiflextreated patients reached a UCVA of $>20 / 40$ after 1 year, compared to $51.6 \%$ for Artisan-treated eyes. ${ }^{198}$ 


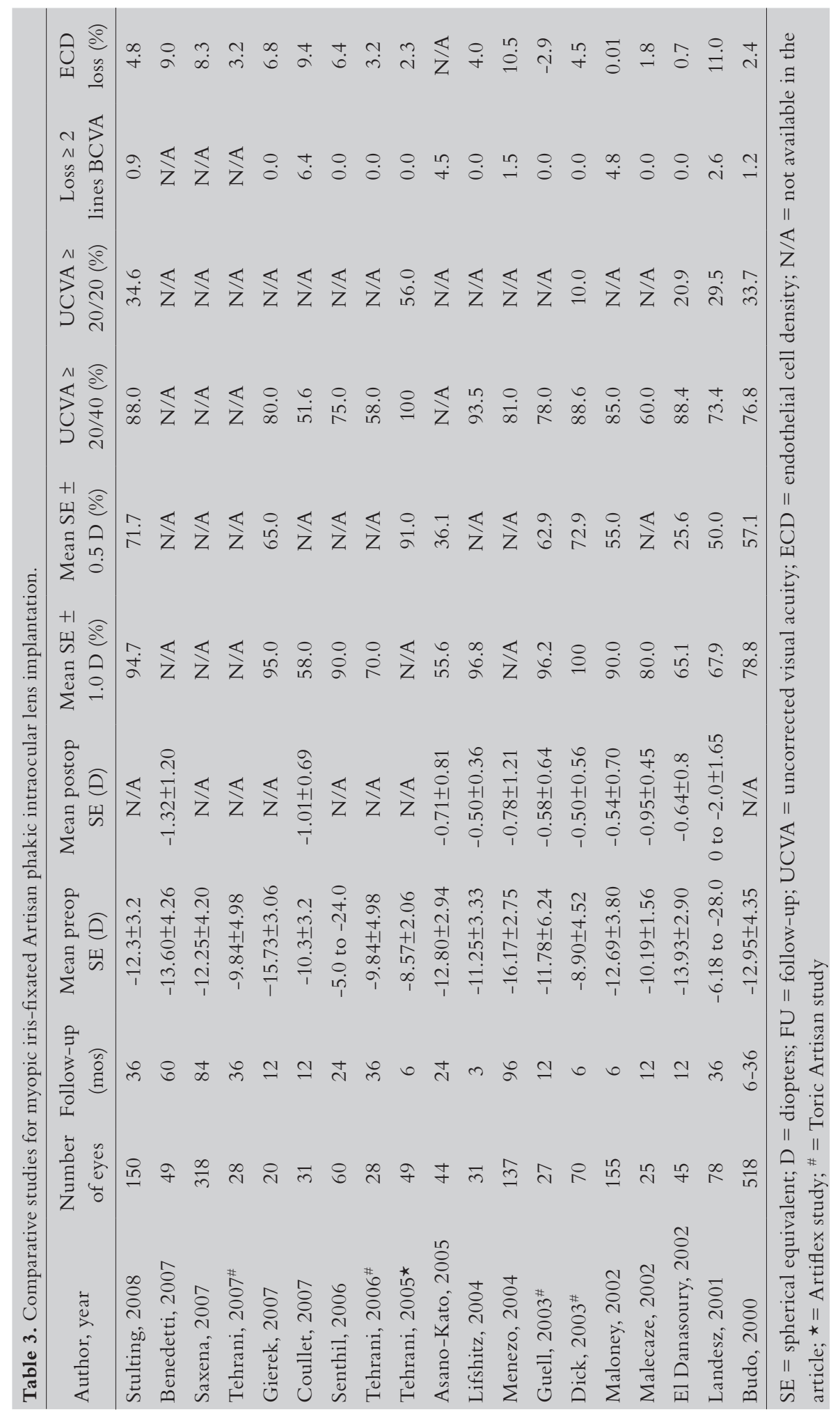


Side effects and complications after iris-fixated phakic IOL implantation

The modernization of these types of IOLs has seen a decrease in the occurrence of postoperative complications, especially in the case of iris-fixated phakic IOLs. Vision-threatening complications are rare with the modern type of Artisan lenses. The risk of complications in phakic hyperopes is greater than in phakic myopes, due to the shallower nature of the anterior chamber depth and less angle space. Complications that can occur after the implantation of iris-fixated phakic IOLs are pupil ovalization ${ }^{213}$, IOL decentration ${ }^{200,214-216}$, low-grade postoperative uveitis $^{217}$ endothelial cell loss ${ }^{59,201,204,218}$, pupil-block glaucoma ${ }^{200,209,219}$, cata$\operatorname{ract}^{200,202}$, endophthalmitis 220,221 , and retinal detachment ${ }^{200,222}$, but are rare. The pupil plays an important role in centration of phakic IOLs, which is important in relation to the optical function of the lens. If the pupil size exceeds the optical zone diameter of the IOL, secondary effects such as glare and HOAs could be markedly increased and decrease visual performance and patient satisfaction. A study by Dick et al showed a reduced postoperative pupil size only under scotopic conditions or medical mydriasis, with a mean scotopic pupil diameter decrease of $1.1 \mathrm{~mm}$ in myopic eyes; the study suggested that the iris-fixated phakic IOL mechanically restricts pupil size changes under low-light conditions and could reduce the incidence of postoperative photic phenomena. ${ }^{213}$ IOL decentration can develop and is often surgeon-dependent, but can also occur after blunt trauma with loosening of the haptic(s). The necessity of re-fixation depends on the amount of decentration, vision, glare complaints and most importantly, the risk of endothelial damage. ${ }^{23,224}$ Chronic inflammation can occur after ArtisanArtiflex IOL implantation. The literature contains a study that showed chronic subclinical inflammation between 1 and 2 years after implantation of this and an angle-supported IOL type. ${ }^{217}$ Two other studies suggested that pigment dispersion and subsequent inflammatory reaction after Artisan phakic IOL implantation may be caused by abnormal pressure on the iris, which can become sandwiched between the crystalline lens and the phakic IOL. ${ }^{223,224}$ In some cases, explantation and exchange of the IOL can be necessary. ${ }^{225}$

\section{Night vision complaints after iris-fixated phakic IOL implantation}

After laser refractive surgery, the chance of experiencing glare and halos increases when treating higher degrees of myopia, since more corneal tissue is removed and the size of the optical zone needs to be smaller to prevent excessively deep ablations. Glare complaints and their relation to night vision and night driving have been described. Laser refractive surgery studies have suggested that the source of glare and halos is the disparity between the pupil size and the optical zone. ${ }^{36}$, ${ }^{226}$ This explanation for glare and halos can probably also be applied in Artisan phakic lens patients, especially when the pupil size exceeds the lens optical zone diameter in dim-light conditions. ${ }^{200,213,227}$ The finding that phakic IOLs decrease 
the horizontal component of dilation more than the vertical component could also explain glare and halos in this patient group. ${ }^{213,228,229}$ The percentage of glare complaints in patients with Artisan phakic IOLs varies between about $14 \%$ to 25\%. 59, 76, 199-201, 203, 204, 207, 209, 211, 214, 218 The Stiles-Crawford effect can be considered as a corrective mechanism, protecting patients with a pupil-optical zone disparity from increased levels of glare after Artisan PIOL implantation, thereby possibly offering a partial explanation for the high satisfaction rates despite reports glare complaints. ${ }^{230}$

\section{Endothelial cell response after iris-fixated phakic IOL implantation}

The endothelial cell density (ECD) is known to decrease over time with a physiologic rate of $0.6 \%$ per year after age $18 .{ }^{231}$ Several short-term and a few recent longer term studies have evaluated corneal ECD loss after Artisan phakic IOL implantation, showing an average ECD loss of $0.7 \%$ to $11.7 \%$ over 3 years time. ${ }^{59}$, 200, 201, 204, 218, 232-234 An anterior chamber depth (measured from the epithelium) of at least $3.0 \mathrm{~mm}$ has been suggested to be an adequate safety measurement for the implantation of the Artisan phakic IOL. ${ }^{200,201,211}$ Surface quality of the Artisan phakic IOL has been shown to be excellent and no contraindications related to surface quality could be found for the implantation of this lens into phakic eyes. $^{235}$

Relative gains in ECD after Artisan phakic IOL implantation have also been shown and can be due to variations in cell density measurements and small study sample sizes. ${ }^{236}$ The corneal endothelial recovery capability after intraocular surgery might be higher than previously assumed; cells in the corneal endothelium might be renewed by stem cells located in a niche at the posterior limbus and increased cell renewal may occur after intraocular surgery. ${ }^{237}$ Both central and peripheral corneal endothelial cells seem to be capable of dividing. ${ }^{236}$ Peripheral corneal ECD seems to be significantly higher than centrally, and function as a physiologic reserve for endothelial cells, which is important for corneal clearness after phakic IOL implantation. Improved endothelial cell morphology after discontinuation of contact lens wear might be another explanation. ${ }^{238}$ Corneal remodeling, rather than ongoing cell loss, following implantation of a phakic posterior chamber IOL, was also presented as an explanation for corneal endothelial cell loss. ${ }^{232,239}$

\section{Cataract after iris-fixated phakic IOL implantation for correction of myopia}

Another concern with phakic IOLs is cataract formation. High myopia in general is known to be associated with cataract formation. ${ }^{240}$ Until now, no clear association has been shown between Artisan phakic IOL implantation and cataract development. Previous studies have shown non-progressive lens vacuoles probably 
caused by intra-operative contact with the crystalline lens or by over-inflation of the anterior chamber with the ocular viscoelastic device. ${ }^{203}$

Studies have reported a low cataract incidence of $1.5 \%$ to $3.0 \%$ after Artisan phakic IOL implantation with a follow-up of up to 4 years. ${ }^{199-201,207}$ An increased incidence of late cataract has not been reported with the Artisan lens. ${ }^{200,202}$

The surgical procedure of phakic IOL implantation and the presence of the phakic IOL in the eye are not assumed to be the only factors resulting in cataract. ${ }^{209,211,}$ 241 The literature suggests that eyes with early changes of the nucleus might promote the development of a clinically significant nuclear cataract after phakic IOL implantation and that pre-cataractous lens changes might be a contraindication for phakic IOL implantation in eyes with high myopia. ${ }^{202}$ Recent studies on the Artisan toric phakic IOL implantation showed no early development of lens opacities. $^{241}$

\section{Higher order aberrations after iris-fixated phakic IOL implantation}

Optical aberrations are optical abnormalities that can occur naturally and after intraocular surgery and play a role in optical quality after refractive surgery. ${ }^{242}$ Optical aberrations may influence postoperative visual outcome and patient satisfaction and need to be included in the preoperative evaluation and selection of refractive surgery candidates.

Most studies on phakic IOLs addressed the refractive outcome, safety profile and complications. Until now, only a few reports have discussed changes in HOA after phakic IOL implantation. An earlier study revealed no tendency toward deterioration of the optical performance after the insertion of an iris-fixated Artisan lens for the treatment of high myopia. ${ }^{242}$ Similar results were demonstrated by a later study with a 12-month follow-up on the foldable iris-fixated Artisan lens which showed no increase in HOA. ${ }^{243}$ Two other recent studies demonstrated a tendency for myopic eyes to show increased amounts of HOA under photopic conditions and in the presence of large pupils. ${ }^{244,245}$

\section{Phakic posterior chamber IOLs}

In 1986, Fyodorov developed a model of a silicone phakic posterior chamber (PPC) IOL for the implantation into phakic eyes with high myopia, meant to be implanted into the ciliary sulcus, immediately in front of the natural crystalline lens. This model initially seemed to lead to good refractive results ${ }^{246,247}$, but eventually appeared to result in a high incidence of cataract formation and high endothelial cell loss. ${ }^{248-256}$ In 1993, Staar Surgical Inc. PPC IOL, the implantable contact lens (ICL), was introduced, which is a modified version of the PPC IOL for the correction of high myopia. Several studies have demonstrated good visual and refractive outcomes, with good efficacy and safety. ${ }^{249,250,254,255,257-259}$ 
However, concerns in relation to increased crystalline lens opacification and cataract formation after PPC IOL implantation remain. The rate of cataract development after PPC IOL implantation has been shown to greatly vary between $9.5 \%$ to $43 \%{ }^{250,258,260-262}$ It is not clear though whether the cataract formation is related to the ICL design itself, to direct surgical trauma, to direct contact between the PPC IOL and the crystalline lens, or to high myopia. Sizing is an important issue for PPC IOLs. ${ }^{250}$ A PPC IOL that is too large would cause undesirable vaulting, and one that is too small could become unstable and decentered, leading to reduced central PPC IOL vaulting over the crystalline lens with an increased risk for lens opacification. ${ }^{258}$ It has been suggested that central vaulting greater than $0.09 \mathrm{~mm}$ protects the crystalline lens from cataract formation. ${ }^{263}$ However, there are reports that do not support this hypothesis. ${ }^{255,256,264-267}$ Improvement of the predictability of PPC IOL vaulting and the choice of lens size has been attempted by measurements of the white-to-white distance, the ciliary sulcus diameter and the posterior chamber width. These measurements did not prove to be helpful, however, due to the lack of correlation between the white-to-white measurements and the ciliary sulcus diameter. ${ }^{268,269}$ Recently, it was suggested that the use of ultrasound biometry is a better method for the prediction of the sulcus-to-sulcus horizontal diameter. ${ }^{270}$

Pigmentary glaucoma and pupillary block glaucoma have also been reported after PPC IOL implantation. ${ }^{255,263}$ The dispersion of pigment could result from continuous contact and friction between the PPC IOL and the pigmented epithelium of the iris occurring during iris movements and accommodation. This liberated pigment and possibly narrowing of the iridocorneal angle can lead to an increase in intraocular pressure.

Endothelial cell loss remains another concern after PPC IOL implantation; reports have shown that endothelial cell loss after PPC IOL implantation varies from $4.41 \%-4.91 \%$ after 6 months to about $12.3 \%$ after 4 years after surgery. ${ }^{239,255}$, 256, 271 The endothelial cell loss is attributed to the traumatic effect of surgery, but it might also be that the PPC IOL itself induces endothelial cell loss as a result of chronic subclinical inflammation. ${ }^{271}$ 


\section{REFRACTIVE SURGERY AFTER CORNEAL SURGERY}

\section{Leading indications and clinical outcome of penetrating keratoplasty (PK)}

Worldwide, PK is one of the most common and successful tissue transplantations. Annually, about 40,000 PK procedures are performed in the US and 750 in the Netherlands. The main goal of PK is the improvement of visual performance. The leading indications for corneal transplantations are bullous keratopathy, Fuchs' dystrophy, keratoconus, corneal scarring, and herpetic disorders. It has been demonstrated that PK is a safe and effective treatment for the corneal diseases commonly transplanted. ${ }^{272-277}$ Few PK studies have reported up to 10-years follow-up, showing the 10-year graft survival rate to be $50 \%$ to $80 \%{ }^{272,275,276,278}$ Reasons for corneal graft failure have been shown to be mainly caused by endothelial failure (in allogeneic PK's the rate of endothelial cell loss is $67 \%$ after 10 years) $)^{273,274}$ and immunologic graft rejection (75\% in less than 2 years and $10 \%$ after 4 years $)^{279}$, but can also be caused by ocular surface disease, increased intraocular pressure $(15 \% \text { higher than } 21 \mathrm{mmHg})^{273}$, suture events ${ }^{279}$ and postoperative astigmatism. ${ }^{280,281}$ In fact, despite the presence of a clear corneal graft, functional vision is often hampered by high levels of post-keratoplasty ametropia and astigmatism.

\section{Post-keratoplasty astigmatism}

High astigmatism is one of the most common and difficult problems after grafting, representing one of the major vision-limiting factors after PK. Some known causes for post-keratoplasty astigmatism are size thickness and shape differences between donor and host eccentric placement, irregular scarring at host junction and asymmetric forces in the cornea resulting in shape alterations. ${ }^{282}$, 283 Despite substantial improvement in visual acuity after PK and a clear graft, significant postoperative astigmatism can remain and limit visual performance and decrease patient satisfaction after successful PK. A thorough study that classified astigmatism patterns after PK found that 24\% showed regular astigmatic patterns and $72 \%$ showed irregular astigmatic patterns. ${ }^{284}$ We know that patients generally do not tolerate more than 3-4 D of anisometropia and/or astigmatism. ${ }^{285}$

\section{Treatment of post-keratoplasty astigmatism}

Currently, there is no standard approach for the management of astigmatism after PK. Treating this type of astigmatism remains a challenge and many techniques can be applied. Various methods have been tried to treat post-keratoplasty astigmatism and include wedge resections, relaxing incisions, customized laser ablation such as PRK, LASIK and LASEK and the implantation of (toric) intraocular lenses. 


\section{Contact lens fitting for treatment of post-PK astigmatism}

Visual rehabilitation after PK usually implies wearing spectacles or contact lenses to correct residual refractive error. Contact lens fitting is usually the first treatment of choice for correcting astigmatism after keratoplasty. They are fitted in $10 \%-30 \%$ of post-keratoplasty patients overall and in post-keratoplasty keratoconus patients this may increase up to $50 \%$. Irregular astigmatism can be corrected by fitting RGP contact lenses or scleral lenses, with varying levels of tolerance. ${ }^{286-290}$ Usually, contact lenses can be worn with sutures in place. However, the higher the post-keratoplasty astigmatism, the more difficult it becomes to correct it and to improve visual performance using contact lenses (e.g. a flat donor corneal flap in combination with a steep recipient). High post-keratoplasty astigmatism can lead to spectacle and contact lens fitting problems, causing quality of life problems such as subjective blur. In cases of contact lens problems (such as dry eye, blepharitis, corneal neovascularization) or contact lens intolerance, a surgical approach may be considered.

\section{Relaxing incisions and compression sutures for treatment of post-keratoplasty astigmatism}

When successful fitting of contact lenses or spectacles is prevented, by excessive regular or irregular post-keratoplasty astigmatism, an attempt can be made to minimize the amount of astigmatism by performing relaxing incisions in the steep corneal meridian and/or, additional compressive sutures in the flat corneal meridian (Table 4). ${ }^{291,292}$ Wedge resections or compression sutures aim to steepen the flat meridian; in this procedure a wedge of tissue is excised from the flat corneal meridian of the recipient or the donor cornea. Relaxing incisions aim to flatten the steep axis. Both procedures result in a "coupling effect": flattening of the steep meridian results in steepening of the flat meridian. These techniques can correct about 4-5 D of astigmatism, with the postoperative astigmatism effect being proportional to the preoperative astigmatism value. ${ }^{293}$ However, relaxing incisions and compression sutures have a low predictability and a minimal effect on the spherical equivalent. ${ }^{280,291-300}$

Recently, the initial results of wedge resections using the femtosecond (FS) laser have shown that the use of the FS laser is a safe and effective alternative for the manual wedge resection techniques, allowing easier, more controlled, and more precise excision of tissue in width, length, and depth, probably leading to improved reproducibility of the technique. ${ }^{301}$ 


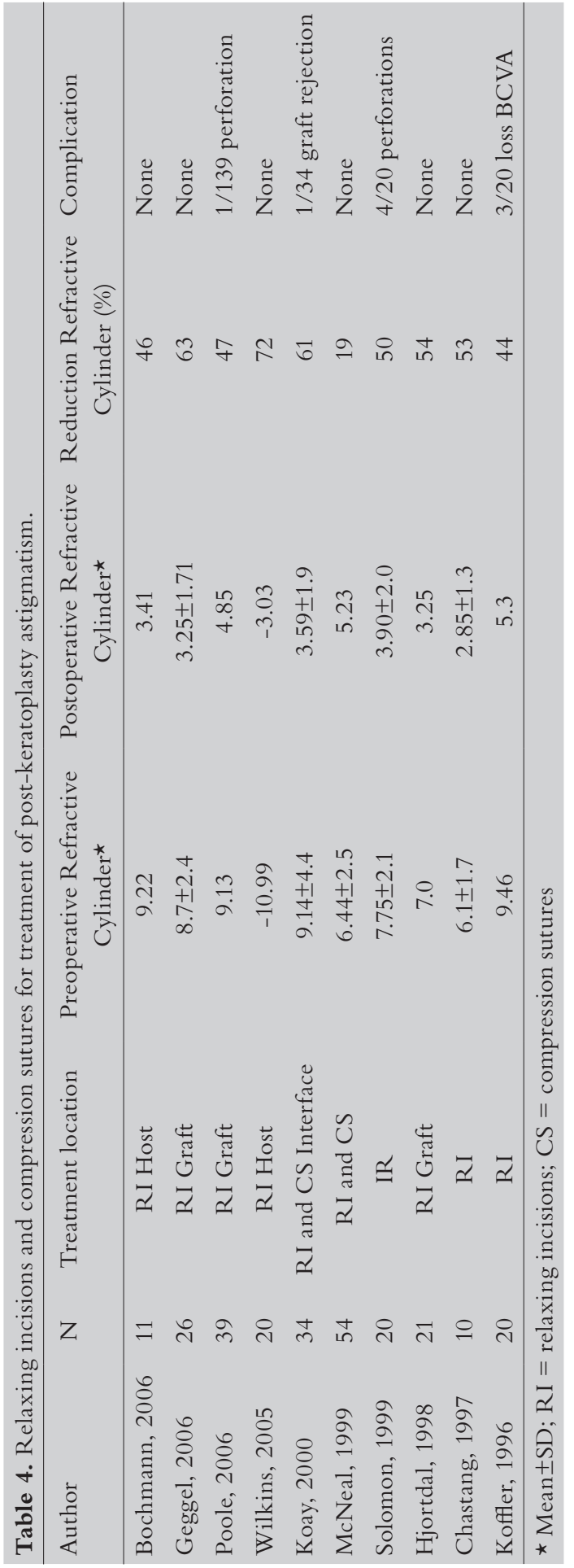


Excimer laser ablations such as PRK, LASIK and LASEK

More recently, excimer laser PRK and LASIK have been used for the correction of post-keratoplasty astigmatism. It is important to note that the goal of therapeutic PRK or LASIK for visual rehabilitation after PK is not by definition the same as for the correction of myopia or astigmatism in virgin eyes and the results are less predictable and less effective.

It should be emphasized that the primary goal of laser ablation treatment of postkeratoplasty astigmatism is the correction of sufficient myopia and astigmatism to allow correction by spectacles or contact lenses.

\section{PRK treatment of post-keratoplasty astigmatism}

The effects of PRK on a corneal transplant may be different to effects of PRK on a virgin eye, due to changes in corneal wound healing in a corneal graft as opposed to normal corneal wound healing. PRK for the treatment of post-PK astigmatism has been shown to lead to a reduction in cylindrical refractive error up to $48 \%$ (Table 5). ${ }^{280,302-308}$ Previous studies show that PRK after PK lead to a higher rate of regression of the refractive effect and that significant corneal haze formation may be more prevalent after PRK for post-PK refractive errors and may lead to irregular astigmatism. PRK using a prophylactic topical application of a diluted MMC solution may prevent corneal haze formation and regression. ${ }^{138,309-311}$

\section{LASIK treatment of post-keratoplasty astigmatism}

LASIK can also be used to treat post-PK astigmatism, being relatively safe and effective, and leading to a reduction in cylindrical refractive error up varying from $48 \%$ to $88 \%$ (Table 6). ${ }^{280,312-326}$ The literature suggests that LASIK may be preferable over PRK for treatment of post-kerastoplasty astigmatism, leading to rapid visual rehabilitation, decreased stromal scarring, minimal risk of regression and the ability to treat greater ranges of refractive error. It has been suggested to wait at least one year after keratoplasty and at least 3 months after suture removal. Adequate wound apposition and sufficient endothelial cell counts are essential in order to avoid interface fluid pockets.

However, there is concern in performing LASIK in eyes with keratoconus, since the lamellar flap is made into an ectatic recipient bed. This may make the patient with preexisting corneal ectasia more likely to develop progressive corneal ectasia and recurrent keratoconus in the graft. Although LASIK can treat higher amounts of post-keratoplasty refractive error, the corneal graft thickness and the amount of ametropia and astigmatism suitable for correction limit the efficacy of the procedure. ${ }^{312,313,318,320,324-326}$ Other drawbacks in performing LASIK after PK are the risk of wound dehiscence due to the high vacuum pressure ${ }^{327-329}$, flap 


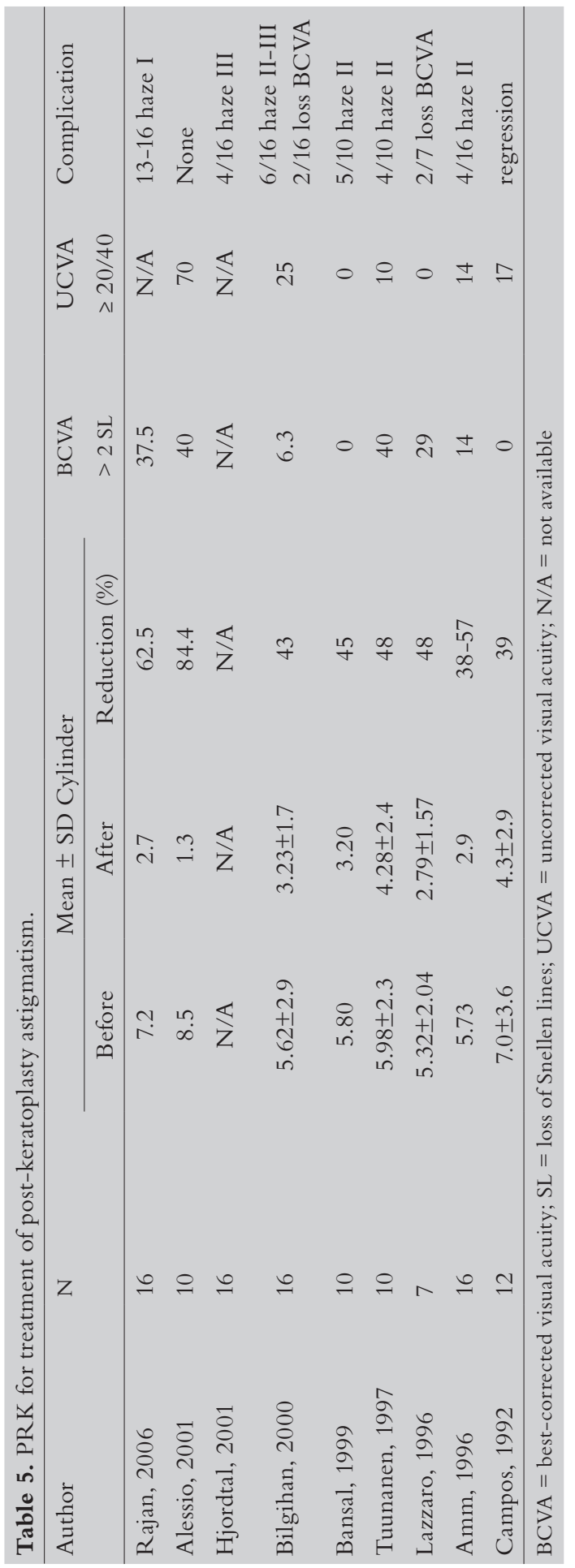




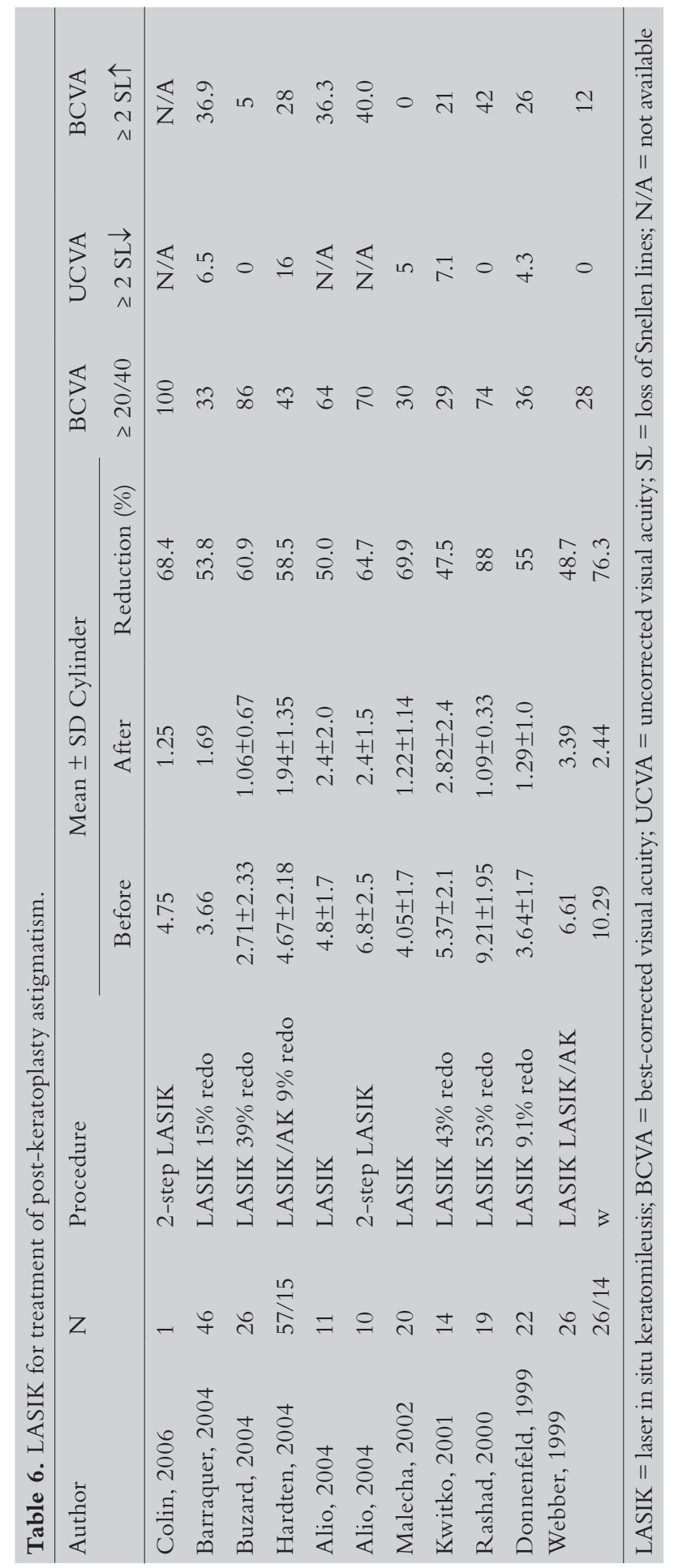


complications in steep corneas ${ }^{312-314,325,329}$, and a high rate of enhancements (upto $53 \%$ of cases). ${ }^{313,318,320,325}$ Other LASIK-related complications like diffuse lamellar keratitis $^{313,314}$, buttonhole flaps ${ }^{330}$, wound dehiscence and epithelial ingrowth have also been reported. ${ }^{313}$

LASIK for treatment of post-keratoplasty can also be carried out as a 2 -step procedure, first to create the corneal flap and some months later to perform excimer laser ablation (Table 6). Because the effect of the flap cut alone may induce a significant reduction of refractive astigmatism in up to $50 \%$ of some patients and because of the high enhancement rate, a 2 -stage LASIK procedure has been proposed. The 2 -step approach could lead to an improved visual outcome in post-PK eyes. Studies have suggested that the 2-step procedure has a better predictability profile than the 1-step procedure in eyes with post-keratoplasty astigmatism, leading to a more precise and better refractive outcome. The appropriate time between the lamellar cut and the laser ablation has not been determined, but it has been shown that a 3 -month period, during which 2 successive corneal topographies performed 1 month apart are stable, is sufficient to improve the outcome of LASIK. ${ }^{331-335}$

\section{Topographically-guided laser ablations for treatment of post-keratoplasty astigmatism}

Topographically-guided laser ablations have been suggested to improve results in eyes with decentered or small optical zones after LASIK or PRK and can be useful in eyes with irregular astigmatism after PK. ${ }^{308,311,336,337}$

\section{LASEK for treatment of post-keratoplasty astigmatism}

A recent study reported on initial results of LASEK with application of MMC for the correction of ametropia and irregular astigmatism after keratoplasty ${ }^{311}$, demonstrating $62.5 \%$ of eyes achieving a SE within $\pm 1 \mathrm{D}$ of the intended correction, with a mean cylinder reduction of $57 \%$ and significant reduction of HOA. There was good refractive stability for over 18 months follow-up. Iatrogenic haze typically occurred, but appeared to be less with adjunctive use of intra-operative MMC. The optimal dose and exposure time for MMC are currently not known; concentration times vary from $0.01 \%$ to $0.02 \%$ and exposure times vary from 12 sec to $120 \mathrm{sec}$. ${ }^{138,338,339}$

Phakic toric IOL implantation for treatment of post-keratoplasty astigmatism

Surgical options for correction of post-keratoplasty astigmatism include the implantation of toric phakic IOLs. The advantage of these surgical techniques is the fact that the implantation requires no direct manipulation or ablation of the donor cornea. 
The iris-fixated toric Artisan IOL has a power range of 7.5 D of cylinder and $-20.5 \mathrm{D}$ of myopia to $+12.0 \mathrm{D}$ of hyperopia and can provide a wide field for correction of post-keratoplasty astigmatism and ametropia. A study by Nuijts et al demonstrated the safety and efficacy of this procedure, showing a $91.0 \%$ reduction of the refractive cylinder, which is higher than LASIK post-PK studies have shown. None of the treated eyes lost BCVA lines and 50\% gained at least 2 lines of BCVA. They also showed that the postoperative refractive error remained stable up to 12 months after the Artisan lens implantation. They reported an endothelial cell loss of reported a cell loss of $7.6 \%$ at 3 months, $21.7 \%$ at 6 months, and $16.6 \%$ at the last follow-up (mean of 8.4 months). ${ }^{340}$ Moshirfar et al have described 2 successful cases of implantation of the iris-fixated phakic IOL for the correction of myopic refractive error after keratoplasty, demonstrating no significant endothelial cell loss. ${ }^{341}$ A more recent study by Moshirfar et all showed 2 cases of Artisan lens implantation post-PK, demonstrating an endothelial cell loss of $25.6 \%$ in one case and $42 \%$ in the other. ${ }^{342}$

After routine $\mathrm{PK}$, the mean annual rate of endothelial cell loss from 3 to 5 years seems to be $7.8 \%$ per year and from 5 to 10 years it seems to be $4.2 \%$ per year. ${ }^{274}$, 275, 343, 344 The corneal endothelium seems to remain relatively stable between 10 and 15 years after PK and it has also been suggested that the rate of endothelial cell loss from 10 to 15 years after surgery may be similar to that of normal corneas. It was hypothesized that late endothelial cell loss may be caused by an aspecific, non-rejection-like inflammation, or perhaps a chronic breakdown of the blood aqueous barrier, but not by an allograft rejection mechanism.

Risk factors that may lead to higher levels of endothelial cell loss after PK are low donor endothelial cell count, older donor age, aphakia, pseudophakia, and older recipient age.

In addition, the implantation of the Artisan lens in post-keratoplasty eyes could be more traumatic for the corneal endothelium, relating to decreased visualisation, as compared to virgin eyes. This could lead to higher endothelial cell loss in the post-keratoplasty group. Endothelial cell loss after Artisan phakic IOL implantation in virgin phakic eyes seems to vary from $0.7 \%$ to $11.7 \%$ over 3 years time. ${ }^{59}$, 76, 199, 202, 204, 207, 211 The higher cell loss in the post-keratoplasty group is probably explained by the increased vulnerability of the corneal graft endothelium that usually has low cell densities and may cause a higher rate of endothelial cell loss. Thus, it cannot be excluded that the implantation of an Artisan iris-fixated IOL after PK with low cell densities may cause a higher rate of endothelial cell loss due to the compromised endothelium. It should be taken into account that accuracy of non-contact specular microscopy for determining endothelial cell density, which is usually around 5\%, is not known in grafts with low cell counts and may introduce bias in the interpretation of our results. Risk factors for endothelial decompensation in corneal grafts with low cell densities have not been clearly defined. 
A potential drawback of implanting an Artisan toric IOL for treatment of postkeratoplasty astigmatism is surgically induced astigmatism, related to the required $5.3 \mathrm{~mm}$ incision size. The biomechanical response of the corneoscleral tissue to the incision may be somewhat unpredictable after PK, and a greater variability in surgically induced astigmatism may be seen. A recent study on implantation of the Artisan toric lens for correction of myopia or hyperopia with astigmatism in virgin non-operated eyes, showed a surgically induced astigmatism of 0.53 D. ${ }^{209}$ However, in a post-keratoplasty astigmatism treatment group a lesser predictability of astigmatism reduction may be acceptable, since the primary goal of treating of astigmatism after PK is the correction of sufficient myopia and astigmatism in order to enable patients to wear spectacles or contact lenses.

Finally, another option is the implantation of a toric pseudophakic posterior chamber IOL to correct post-keratoplasty astigmatism. A few studies have described post-PK eyes in which standard phaco-emulsification and subsequent implantation of this toric IOL were performed. The serrated Z-design haptic of the lens is intended to prevent risk of lens rotation and subsequent change in the angle of the corrective cylinder. These studies suggest that this toric lens can provide a very good refractive outcome for eyes suffering from high degrees of post-keratoplasty astigmatism without significant effects on graft survival. ${ }^{345-348}$ 


\section{REFERENCES}

1. Koch DD, Kohnen T, Obstbaum SA, Rosen ES. Format for reporting refractive surgical data. J Cataract Refract Surg 1998;24:285-7.

2. Kohnen T. Measuring vision in refractive surgery. J Cataract Refract Surg 2001;27:1897-8.

3. Houtman DM. Managing patient expectations. Int Ophthalmol Clin 2000;40:29-34.

4. Nijkamp MD, Nuijts RM, Borne B, Webers CA, van der Horst F, Hendrikse F. Determinants of patient satisfaction after cataract surgery in 3 settings. J Cataract Refract Surg 2000;26:1379-88.

5. Cadotte E, RB. W, Jenkins R. Expectations and norms in models of consumer satisfaction. J Marketing Res 1987;24:305-314.

6. Nijkamp MD. Determinants of patient satsifaction after cataract surgery. Doctoral thesis 2003 .

7. Giese JL, Cote JA. Defining Consumer Satisfaction. Academy of Marketing Science Review 2002;2000:1-24.

8. Bailey MD, Mitchell GL, Dhaliwal DK, Boxer Wachler BS, Zadnik K. Patient satisfaction and visual symptoms after laser in situ keratomileusis. Ophthalmology 2003;110:1371-8.

9. Brunette I, Gresset J, Boivin JF, Boisjoly H, Makni H. Functional outcome and satisfaction after photorefractive keratectomy. Part 1: development and validation of a survey questionnaire. Ophthalmology 2000;107:1783-9.

10. Brunette I, Gresset J, Boivin JF, et al. Functional outcome and satisfaction after photorefractive keratectomy. Part 2: survey of 690 patients. Ophthalmology 2000;107:1790-6.

11. McDonnell PJ, Mangione C, Lee P, et al. Responsiveness of the National Eye Institute Refractive Error Quality of Life instrument to surgical correction of refractive error. Ophthalmology 2003;110:2302-9.

12. McGhee CN, Craig JP, Sachdev N, Weed KH, Brown AD. Functional, psychological, and satisfaction outcomes of laser in situ keratomileusis for high myopia. J Cataract Refract Surg 2000;26:497-509.

13. Schallhorn SC, Kaupp SE, Tanzer DJ, Tidwell J, Laurent J, Bourque LB. Pupil size and quality of vision after LASIK. Ophthalmology 2003;110:1606-14.

14. Hammond SD, Jr., Puri AK, Ambati BK. Quality of vision and patient satisfaction after LASIK. Curr Opin Ophthalmol 2004;15:328-32.

15. Tuan KM. Visual experience and patient satisfaction with wavefront-guided laser in situ keratomileusis. J Cataract Refract Surg 2006;32:577-83.

16. Berry S, Mangione CM, Lindblad AS, McDonnell PJ. Development of the National Eye Institute refractive error correction quality of life questionnaire: focus groups. Ophthalmology 2003;110:2285-91.

17. Hays RD, Mangione CM, Ellwein L, Lindblad AS, Spritzer KL, McDonnell PJ. Psychometric properties of the National Eye Institute-Refractive Error Quality of Life instrument. Ophthalmology 2003;110:2292-301. 
18. Nijkamp MD, Sixma HJ, Afman H, et al. Quality of care from the perspective of the cataract patient: the reliability and validity of the QUOTE-cataract. Br J Ophthalmol 2002;86:840-2.

19. Vitale S, Schein OD, Meinert CL, Steinberg EP. The refractive status and vision profile: a questionnaire to measure vision-related quality of life in persons with refractive error. Ophthalmology 2000;107:1529-39.

20. Pager CK. Expectations and outcomes in cataract surgery: a prospective test of 2 models of satisfaction. Arch Ophthalmol 2004;122:1788-92.

21. Rosen PN, Kaplan RM, David K. Measuring outcomes of cataract surgery using the Quality of Well-Being Scale and VF-14 Visual Function Index. J Cataract Refract Surg 2005;31:369-78.

22. Valderas JM, Rue M, Guyatt G, Alonso J. The impact of the VF-14 index, a perceived visual function measure, in the routine management of cataract patients. Qual Life Res 2005;14:1743-53.

23. Khan-Lim D, Craig JP, McGhee CN. Defining the content of patient questionnaires: reasons for seeking laser in situ keratomileusis for myopia. J Cataract Refract Surg 2002;28:788-94.

24. Tahzib NG, Bootsma SJ, Eggink FA, Nabar VA, Nuijts RM. Functional outcomes and patient satisfaction after laser in situ keratomileusis for correction of myopia. J Cataract Refract Surg 2005;31:1943-51.

25. Fyodorov SN, Durnev VV. Surgical correction of complicated myopic astigmatism by means of dissection of circular ligament of cornea. Ann Ophthalmol 1981;13:115-8.

26. Rowsey JJ, Morley WA. Surgical correction of moderate myopia: which method should you choose? I. Radial keratotomy will always have a place. Surv Ophthalmol 1998;43:147-56.

27. Choi DM, Thompson RW, Jr., Price FW, Jr. Incisional refractive surgery. Curr Opin Ophthalmol 2002;13:237-41.

28. McDonnell PJ. Refractive surgery. Br J Ophthalmol 1999;83:1257-60.

29. Waring GO, 3rd, Lynn MJ, McDonnell PJ. Results of the prospective evaluation of radial keratotomy (PERK) study 10 years after surgery. Arch Ophthalmol 1994;112:1298-308.

30. Deitz MR, Sanders DR, Raanan MG, DeLuca M. Long-term (5- to 12-year) followup of metal-blade radial keratotomy procedures. Arch Ophthalmol 1994;112:614-20.

31. Salz JJ, Salz JM, Salz M, Jones D. Ten years experience with a conservative approach to radial keratotomy. Refract Corneal Surg 1991;7:12-22.

32. Sawelson H, Marks RG. Ten-year refractive and visual results of radial keratotomy. Ophthalmology 1995;102:1892-901.

33. Salamon SA, Hjortdal JO, Ehlers N. Refractive results of radial keratotomy: a ten-year retrospective study. Acta Ophthalmol Scand 2000;78:566-8.

34. McDonnell PJ, Caroline PJ, Salz J. Irregular astigmatism after radial and astigmatic keratotomy. Am J Ophthalmol 1989;107:42-6.

35. Rashid ER, Waring GO, 3rd. Complications of radial and transverse keratotomy. Surv Ophthalmol 1989;34:73-106. 
36. Fan-Paul NI, Li J, Miller JS, Florakis GJ. Night vision disturbances after corneal refractive surgery. Surv Ophthalmol 2002;47:533-46.

37. Krumeich JH, Knulle A, Daniel J. Improved technique of circular keratotomy for the correction of corneal astigmatism. J Refract Surg 1997;13:255-62.

38. Suarez E, Verity SM, Torres FY, Assil KK. Two-incision radial keratotomy for low myopia with astigmatism. J Cataract Refract Surg 1997;23:502-8.

39. Kwitko ML, Jovkar S, Yan H, Rymer S. Arcuate keratotomy to correct naturally occurring astigmatism. J Cataract Refract Surg 1996;22:1439-42.

40. Chavez S, Chayet A, Celikkol L, ParkerJ, Celikkol G, Feldman ST. Analysis of astigmatic keratotomy with a 5.0-mm optical clear zone. Am J Ophthalmol 1996;121:65-76.

41. Seiler T, Wollensak J. Myopic photorefractive keratectomy with the excimer laser. One-year follow-up. Ophthalmology 1991;98:1156-63.

42. Trokel SL, Srinivasan R, Braren B. Excimer laser surgery of the cornea. Am J Ophthalmol 1983;96:710-5.

43. Stephenson CG, Gartry DS, O‘Brart DP, Kerr-Muir MG, Marshall J. Photorefractive keratectomy. A 6-year follow-up study. Ophthalmology 1998;105:273-81.

44. Hamberg-Nystrom H, Fagerholm P, Tengroth B, Sjoholm C. Thirty-six month follow-up of excimer laser photorefractive keratectomy for myopia. Ophthalmic Surg Lasers 1996;27:S418-20.

45. Gartry DS, Kerr Muir MG, Marshall J. Excimer laser photorefractive keratectomy. 18-month follow-up. Ophthalmology 1992;99:1209-19.

46. Epstein D, Fagerholm P, Hamberg-Nystrom H, Tengroth B. Twenty-four-month follow-up of excimer laser photorefractive keratectomy for myopia. Refractive and visual acuity results. Ophthalmology 1994;101:1558-63; discussion 1563-4.

47. Rajan MS, Jaycock P, O'Brart D, Nystrom HH, Marshall J. A long-term study of photorefractive keratectomy; 12-year follow-up. Ophthalmology 2004;111:1813-24.

48. O'Connor J, O'Keeffe M, Condon PI. Twelve-year follow-up of photorefractive keratectomy for low to moderate myopia. J Refract Surg 2006;22:871-7.

49. Barraquer JI. [Autokeratoplasty with optical carving for the correction of myopia (Keratomileusis)]. An Med Espec 1965;51:66-82.

50. Barraquer JI. Keratomileusis for myopia and aphakia. Ophthalmology 1981;88:701-8.

51. Pallikaris IG, Papatzanaki ME, Siganos DS, Tsilimbaris MK. A corneal flap technique for laser in situ keratomileusis. Human studies. Arch Ophthalmol 1991;109:1699-702.

52. Shortt AJ, Bunce C, Allan BD. Evidence for superior efficacy and safety of LASIK over photorefractive keratectomy for correction of myopia. Ophthalmology 2006;113:1897-908.

53. Awwad ST, McCulley JP. Wavefront-guided LASIK: recent developments and results. Int Ophthalmol Clin 2006;46:27-38.

54. Pop M, Payette Y. Photorefractive keratectomy versus laser in situ keratomileusis: a control-matched study. Ophthalmology 2000;107:251-7.

55. Sugar A, Rapuano CJ, Culbertson WW, et al. Laser in situ keratomileusis for myopia and astigmatism: safety and efficacy: a report by the American Academy of Ophthalmology. Ophthalmology 2002;109:175-87. 
56. Lin JM, Tsai YY. Laser in situ keratomileusis for different degrees of myopia. Acta Ophthalmol Scand 2005;83:40-5.

57. Sekundo W, Bonicke K, Mattausch P, Wiegand W. Six-year follow-up of laser in situ keratomileusis for moderate and extreme myopia using a first-generation excimer laser and microkeratome. J Cataract Refract Surg 2003;29:1152-8.

58. Nuijts RM, Nabar VA, Hament WJ, Eggink FA. Wavefront-guided versus standard laser in situ keratomileusis to correct low to moderate myopia. J Cataract Refract Surg 2002;28:1907-13.

59. Malecaze FJ, Hulin H, Bierer P, et al. A randomized paired eye comparison of two techniques for treating moderately high myopia: LASIK and artisan phakic lens. Ophthalmology 2002;109:1622-30.

60. Shaikh NM, Manche EE. Laser in situ keratomileusis for myopia and compound myopic astigmatism using the Technolas 217 scanning-spot laser. J Cataract Refract Surg 2002;28:485-90.

61. Yang CN, Shen EP, Hu FR. Laser in situ keratomileusis for the correction of myopia and myopic astigmatism. J Cataract Refract Surg 2001;27:1952-60.

62. Balazsi G, Mullie M, Lasswell L, Lee PA, Duh YJ. Laser in situ keratomileusis with a scanning excimer laser for the correction of low to moderate myopia with and without astigmatism. J Cataract Refract Surg 2001;27:1942-51.

63. Gimbel HV, van Westenbrugge JA, Penno EE, Ferensowicz M, Feinerman GA, Chen R. Simultaneous bilateral laser in situ keratomileusis: safety and efficacy. Ophthalmology 1999;106:1461-7; discussion 1467-8.

64. Tole DM, McCarty DJ, Couper T, Taylor HR. Comparison of laser in situ keratomileusis and photorefractive keratectomy for the correction of myopia of -6.00 diopters or less. Melbourne Excimer Laser Group. J Refract Surg 2001;17:46-54.

65. Bailey MD, Zadnik K. Outcomes of LASIK for myopia with FDA-approved lasers. Cornea 2007;26:246-54.

66. el Danasoury MA, el Maghraby A, Klyce SD, Mehrez K. Comparison of photorefractive keratectomy with excimer laser in situ keratomileusis in correcting low myopia (from -2.00 to -5.50 diopters). A randomized study. Ophthalmology 1999;106:411-20; discussion 420-1.

67. Reviglio VE, Bossana EL, Luna JD, Muino JC, Juarez CP. Laser in situ keratomileusis for myopia and hyperopia using the Lasersight 200 laser in 300 consecutive eyes. J Refract Surg 2000;16:716-23.

68. Sakimoto T, Rosenblatt MI, Azar DT. Laser eye surgery for refractive errors. Lancet 2006;367:1432-47.

69. Netto MV, Dupps W, Jr., Wilson SE. Wavefront-guided ablation: evidence for efficacy compared to traditional ablation. Am J Ophthalmol 2006;141:360-368.

70. Wilson SE. Clinical practice. Use of lasers for vision correction of nearsightedness and farsightedness. N Engl J Med 2004;351:470-5.

71. O`Doherty M, O'Keeffe M, Kelleher C. Five year follow up of laser in situ keratomileusis for all levels of myopia. Br J Ophthalmol 2006;90:20-3. 
72. Knorz MC, Jendritza B, Liermann A, Hugger P, Liesenhoff H. [LASIK for myopia correction. 2-year follow-up]. Ophthalmologe 1998;95:494-8.

73. Hjortdal JO, Moller-Pedersen T, Ivarsen A, Ehlers N. Corneal power, thickness, and stiffness: results of a prospective randomized controlled trial of PRK and LASIK for myopia. J Cataract Refract Surg 2005;31:21-9.

74. McDonald MB, Carr JD, Frantz JM, et al. Laser in situ keratomileusis for myopia up to -11 diopters with up to -5 diopters of astigmatism with the summit autonomous LADARVision excimer laser system. Ophthalmology 2001;108:309-16.

75. Lyle WA, Jin GJ. Laser in situ keratomileusis with the VISX Star laser for myopia over -10.0 diopters. J Cataract Refract Surg 2001;27:1812-22.

76. El Danasoury MA, El Maghraby A, Gamali TO. Comparison of iris-fixed Artisan lens implantation with excimer laser in situ keratomileusis in correcting myopia between -9.00 and -19.50 diopters: a randomized study. Ophthalmology 2002;109:955-64.

77. Kymionis GD, Tsiklis NS, Astyrakakis N, Pallikaris AI, Panagopoulou SI, Pallikaris IG. Eleven-year follow-up of laser in situ keratomileusis. J Cataract Refract Surg 2007;33:191-6.

78. Marinho A, Pinto MC, Pinto R, Vaz F, Neves MC. LASIK for high myopia: one year experience. Ophthalmic Surg Lasers 1996;27:S517-20.

79. Bailey MD, Mitchell GL, Dhaliwal DK, et al. Reasons patients recommend laser in situ keratomileusis. J Cataract Refract Surg 2004;30:1861-6.

80. Han HS, Song JS, Kim HM. Long-term results of laser in situ keratomileusis for high myopia. Korean J Ophthalmol 2000;14:1-6.

81. Mulhern MG, Condon PI, O'Keefe M. Myopic and hyperopic laser in situ keratomileusis retreatments: indications, techniques, limitations, and results. J Cataract Refract Surg 2001;27:1278-87.

82. Schallhorn SC, Amesbury EC, Tanzer DJ. Avoidance, recognition, and management of LASIK complications. Am J Ophthalmol 2006;141:733-9.

83. Farah SG, Azar DT, Gurdal C, Wong J. Laser in situ keratomileusis: literature review of a developing technique. J Cataract Refract Surg 1998;24:989-1006.

84. Ambrosio R, Jr., Wilson SE. Complications of laser in situ keratomileusis: etiology, prevention, and treatment. J Refract Surg 2001;17:350-79.

85. Melki SA, Azar DT. LASIK complications: etiology, management, and prevention. Surv Ophthalmol 2001;46:95-116.

86. Iskander NG, Peters NT, Penno EA, Gimbel HV. Postoperative complications in laser in situ keratomileusis. Curr Opin Ophthalmol 2000;11:273-9.

87. Dantas PE. Corneal ectasia after refractive surgery. Ophthalmology 2001;108:834-5.

88. Lifshitz T, Levy J, Klemperer I, Levinger S. Late bilateral keratectasia after LASIK in a low myopic patient. J Refract Surg 2005;21:494-6.

89. Dupps WJ, Jr. Biomechanical modeling of corneal ectasia. J Refract Surg 2005;21:186-90. 
90. Reinstein DZ, Srivannaboon S, Archer TJ, Silverman RH, Sutton H, Coleman DJ. Probability model of the inaccuracy of residual stromal thickness prediction to reduce the risk of ectasia after LASIK part II: quantifying population risk. J Refract Surg 2006;22:861-70.

91. Reinstein DZ, Srivannaboon S, Archer TJ, Silverman RH, Sutton H, Coleman DJ. Probability model of the inaccuracy of residual stromal thickness prediction to reduce the risk of ectasia after LASIK part I: quantifying individual risk. J Refract Surg 2006;22:851-60.

92. Pallikaris IG, Kymionis GD, Astyrakakis NI. Corneal ectasia induced by laser in situ keratomileusis. J Cataract Refract Surg 2001;27:1796-802.

93. Rad AS, Jabbarvand M, Saifi N. Progressive keratectasia after laser in situ keratomileusis. J Refract Surg 2004;20:S718-22.

94. Binder PS. Ectasia after laser in situ keratomileusis. J Cataract Refract Surg 2003;29:2419-29.

95. Klein SR, Epstein RJ, Randleman JB, Stulting RD. Corneal ectasia after laser in situ keratomileusis in patients without apparent preoperative risk factors. Cornea 2006;25:388-403.

96. Rabinowitz YS. Ectasia after laser in situ keratomileusis. Curr Opin Ophthalmol 2006;17:421-6.

97. Randleman JB. Post-laser in-situ keratomileusis ectasia: current understanding and future directions. Curr Opin Ophthalmol 2006;17:406-12.

98. Ito M, Hori-Komai Y, Toda I, Tsubota K. Risk factors and retreatment results of intraoperative flap complications in LASIK. J Cataract Refract Surg 2004;30:1240-7.

99. Cheng AC, Wong VW, Rao SK, Lam DS. Repositioning of free cap four days after LASIK. J Refract Surg 2007;23:625-7.

100. Lichter H, Stulting RD, Waring GO, 3rd, Russell GE, Carr J. Buttonholes during LASIK: etiology and outcome. J Refract Surg 2007;23:472-6.

101. Seiler T, Koufala K, Richter G. Iatrogenic keratectasia after laser in situ keratomileusis. J Refract Surg 1998;14:312-7.

102. Reinstein DZ. Risk of ectasia after laser in situ keratomileusis. Invest Ophthal Vis Sc 1999;ARVO abstract 3942.

103. Tabbara KF, Kotb AA. Risk factors for corneal ectasia after LASIK. Ophthalmology 2006;113:1618-22.

104. Guirao A. Theoretical elastic response of the cornea to refractive surgery: risk factors for keratectasia. J Refract Surg 2005;21:176-85.

105. Binder PS, Lindstrom RL, Stulting RD, et al. Keratoconus and corneal ectasia after LASIK. J Cataract Refract Surg 2005;31:2035-8.

106. Binder PS, Lindstrom RL, Stulting RD, et al. Keratoconus and corneal ectasia after LASIK. J Refract Surg 2005;21:749-52.

107. Randleman JB, Russell B, Ward MA, Thompson KP, Stulting RD. Risk factors and prognosis for corneal ectasia after LASIK. Ophthalmology 2003;110:267-75. 
108. Randleman JB, Hewitt SM, Lynn MJ, Stulting RD. A comparison of 2 methods for estimating residual stromal bed thickness before repeat LASIK. Ophthalmology 2005;112:98-103.

109. Rao SN, Epstein RJ. Early onset ectasia following laser in situ keratomileusus: case report and literature review. J Refract Surg 2002;18:177-84.

110. Dupps WJ, Jr., Wilson SE. Biomechanics and wound healing in the cornea. Exp Eye Res 2006;83:709-20.

111. Condon PI, O'Keefe M, Binder PS. Long-term results of laser in situ keratomileusis for high myopia: risk for ectasia. J Cataract Refract Surg 2007;33:583-90.

112. Eggink FA, Beekhuis WH. Contact lens fitting in a patient with keratectasia after laser in situ keratomileusis. J Cataract Refract Surg 2001;27:1119-23.

113. Buhren J, Kuhne C, Kohnen T. Defining subclinical keratoconus using corneal firstsurface higher-order aberrations. Am J Ophthalmol 2007;143:381-9.

114. Randleman JB, Woodward M, Lynn MJ, Stulting RD. Risk Assessment for Ectasia after Corneal Refractive Surgery. Ophthalmology 2007.

115. Salz JJ, Binder PS. Is there a ,magic number“ to reduce the risk of ectasia after laser in situ keratomileusis and photorefractive keratectomy? Am J Ophthalmol 2007;144:284-5.

116. Camellin M. LASEK may offer the advantages of both LASIK and PRK. Ocular Surgery News 1999:28.

117. Camellin M. LASEK technique promising after 1 year of experience. Ocular Surgery News 2000;18:14-17.

118. Vinciguerra P, Camesasca FI. Butterfly laser epithelial keratomileusis for myopia. J Refract Surg 2002;18:S371-3.

119. Lee JB, Seong GJ, Lee JH, Seo KY, Lee YG, Kim EK. Comparison of laser epithelial keratomileusis and photorefractive keratectomy for low to moderate myopia. J Cataract Refract Surg 2001;27:565-70.

120. Kornilovsky IM. Clinical results after subepithelial photorefractive keratectomy (LASEK). J Refract Surg 2001;17:S222-3.

121. Azar DT, Ang RT, Lee JB, et al. Laser subepithelial keratomileusis: electron microscopy and visual outcomes of flap photorefractive keratectomy. Curr Opin Ophthalmol 2001;12:323-8.

122. Dastjerdi MH, Soong HK. LASEK (laser subepithelial keratomileusis). Curr Opin Ophthalmol 2002;13:261-3.

123. Feit R, Taneri S, Azar DT, Chen CC, Ang RT. LASEK results. Ophthalmol Clin North Am 2003;16:127-35, viii.

124. Autrata R, Rehurek J. Laser-assisted subepithelial keratectomy for myopia: two-year follow-up. J Cataract Refract Surg 2003;29:661-8.

125. Taneri S, Feit R, Azar DT. Safety, efficacy, and stability indices of LASEK correction in moderate myopia and astigmatism. J Cataract Refract Surg 2004;30:2130-7.

126. Tobaigy FM, Ghanem RC, Sayegh RR, Hallak JA, Azar DT. A control-matched comparison of laser epithelial keratomileusis and laser in situ keratomileusis for low to moderate myopia. Am J Ophthalmol 2006;142:901-8. 
127. Pirouzian A, Thornton J, Ngo S. One-year outcomes of a bilateral randomized prospective clinical trial comparing laser subepithelial keratomileusis and photorefractive keratectomy. J Refract Surg 2006;22:575-9.

128. Lee HK, Lee KS, Kim JK, Kim HC, Seo KR, Kim EK. Epithelial healing and clinical outcomes in excimer laser photorefractive surgery following three epithelial removal techniques: mechanical, alcohol, and excimer laser. Am J Ophthalmol 2005;139:56-63.

129. Winkler von Mohrenfels C, Huber A, Gabler B, et al. Wavefront-guided laser epithelial keratomileusis with the wavelight concept system 500. J Refract Surg 2004;20:S565-9.

130. Shahinian L, Jr. Laser-assisted subepithelial keratectomy for low to high myopia and astigmatism. J Cataract Refract Surg 2002;28:1334-42.

131. Kim JK, Kim SS, Lee HK, et al. Laser in situ keratomileusis versus laser-assisted subepithelial keratectomy for the correction of high myopia. J Cataract Refract Surg 2004;30:1405-11.

132. Claringbold TV, 2nd. Laser-assisted subepithelial keratectomy for the correction of myopia. J Cataract Refract Surg 2002;28:18-22.

133. Partal AE, Rojas MC, Manche EE. Analysis of the efficacy, predictability, and safety of LASEK for myopia and myopic astigmatism using the Technolas 217 excimer laser. J Cataract Refract Surg 2004;30:2138-44.

134. Yee RW, Yee SB. Update on laser subepithelial keratectomy (LASEK). Curr Opin Ophthalmol 2004;15:333-41.

135. Kaya V, Oncel B, Sivrikaya H, Yilmaz OF. Prospective, paired comparison of laser in situ keratomileusis and laser epithelial keratomileusis for myopia less than -6.00 diopters. J Refract Surg 2004;20:223-8.

136. Vinciguerra P, Camesasca FI, Torres IM. One-year results of custom laser epithelial keratomileusis with the Nidek system. J Refract Surg 2004;20:S699-704.

137. Vinciguerra P, Camesasca FI, Torres IM. Transition zone design and smoothing in custom laser-assisted subepithelial keratectomy. J Cataract Refract Surg 2005;31:39-47.

138. Carones F, Vigo L, Scandola E, Vacchini L. Evaluation of the prophylactic use of mitomycin-C to inhibit haze formation after photorefractive keratectomy. J Cataract Refract Surg 2002;28:2088-95.

139. Carones F, Vigo L, Carones AV, Brancato R. Evaluation of photorefractive keratectomy retreatments after regressed myopic laser in situ keratomileusis. Ophthalmology 2001;108:1732-7.

140. Argento C, Cosentino MJ, Ganly M. Comparison of laser epithelial keratomileusis with and without the use of mitomycin C. J Refract Surg 2006;22:782-6.

141. Camellin M. Laser epithelial keratomileusis with mitomycin C: indications and limits. J Refract Surg 2004;20:S693-8.

142. Azar DT, Jain S. Topical MMC for subepithelial fibrosis after refractive corneal surgery. Ophthalmology 2001;108:239-40.

143. Lacayo GO, 3rd, Majmudar PA. How and when to use mitomycin-C in refractive surgery. Curr Opin Ophthalmol 2005;16:256-9. 
144. Majmudar PA, Raviv T, Dennis RF, Epstein RJ. Subepithelial fibrosis after RK. J Cataract Refract Surg 2000;26:1433-4.

145. Majmudar PA, Forstot SL, Dennis RF, et al. Topical mitomycin-C for subepithelial fibrosis after refractive corneal surgery. Ophthalmology 2000;107:89-94.

146. Matsumoto JC, Chu YS. Epi-LASIK update: overview of techniques and patient management. Int Ophthalmol Clin 2006;46:105-15.

147. Pallikaris IG, Kalyvianaki MI, Katsanevaki VJ, Ginis HS. Epi-LASIK: preliminary clinical results of an alternative surface ablation procedure. J Cataract Refract Surg 2005;31:879-85.

148. Pallikaris IG, Katsanevaki VJ, Kalyvianaki MI, Naoumidi, II. Advances in subepithelial excimer refractive surgery techniques: Epi-LASIK. Curr Opin Ophthalmol 2003;14:207-12.

149. Brown SM, Khanani AM. Night vision complaints after LASIK. Ophthalmology 2004;111:1619-20; author reply 1920.

150. Pop M, Payette Y. Risk factors for night vision complaints after LASIK for myopia. Ophthalmology 2004;111:3-10.

151. Salz JJ, Boxer Wachler BS, Holladay JT, Trattler W. Night vision complaints after LASIK. Ophthalmology 2004;111:1620-1; author reply 1621-2.

152. Lee J, Lee J, Park K, Cho W, Kim JY, Kang HY. Assessing the value of laser in situ keratomileusis by patient-reported outcomes using quality of life assessment. J Refract Surg 2005;21:59-71.

153. Weisinger HS. Assessing the value of LASIK by patient-reported outcomes using quality of life assessment. J Refract Surg 2006;22:14-5; author reply 15.

154. Klyce SD. Night vision after LASIK: the pupil proclaims innocence. Ophthalmology 2004;111:1-2.

155. Probst LE. The problem with pupils. J Cataract Refract Surg 2004;30:2-4.

156. Lee YC, Hu FR, Wang IJ. Quality of vision after laser in situ keratomileusis: influence of dioptric correction and pupil size on visual function. J Cataract Refract Surg 2003;29:769-77.

157. Salz JJ, Trattler W. Pupil size and corneal laser surgery. Curr Opin Ophthalmol 2006;17:373-9.

158. Holladay JT, Dudeja DR, Chang J. Functional vision and corneal changes after laser in situ keratomileusis determined by contrast sensitivity, glare testing, and corneal topography. J Cataract Refract Surg 1999;25:663-9.

159. Jabbur NS, Sakatani K, O‘Brien TP. Survey of complications and recommendations for management in dissatisfied patients seeking a consultation after refractive surgery. $\mathrm{J}$ Cataract Refract Surg 2004;30:1867-74.

160. Eggink FA, Beekhuis WH, Nuijts RM. Rigid gas-permeable contact lens fitting in LASIK patients for the correction of multifocal corneas. Graefes Arch Clin Exp Ophthalmol 2001;239:361-6.

161. Eggink FA, Eggink CA, Beekhuis WH. Postoperative management and follow-up after corneal flap loss following laser in situ keratomileusis. J Cataract Refract Surg 2002;28:175-9. 
162. Mrochen M, Kaemmerer M, Seiler T. Wavefront-guided laser in situ keratomileusis: early results in three eyes. J Refract Surg 2000;16:116-21.

163. MacRae SM, Williams DR. Wavefront guided ablation. Am J Ophthalmol 2001;132:915-9.

164. Carones F, Vigo L, Scandola E. Wavefront-guided treatment of abnormal eyes using the LADARVision platform. J Refract Surg 2003;19:S703-8.

165. Lawless MA, Hodge C, Rogers CM, Sutton GL. Laser in situ keratomileusis with Alcon CustomCornea. J Refract Surg 2003;19:S691-6.

166. Kohnen T, Kuhne C, Buhren J. The future role of wavefront-guided excimer ablation. Graefes Arch Clin Exp Ophthalmol 2006.

167. Porter J, MacRae S, Yoon G, Roberts C, Cox IG, Williams DR. Separate effects of the microkeratome incision and laser ablation on the eye's wave aberration. Am J Ophthalmol 2003;136:327-37.

168. Hiatt JA, Grant CN, Boxer Wachler BS. Establishing analysis parameters for spherical aberration after wavefront LASIK. Ophthalmology 2005;112:998-1002.

169. Mrochen M, Jankov M, Bueeler M, Seiler T. Correlation between corneal and total wavefront aberrations in myopic eyes. J Refract Surg 2003;19:104-12.

170. Kohnen T, Buhren J, Kuhne C, Mirshahi A. Wavefront-guided LASIK with the Zyoptix 3.1 system for the correction of myopia and compound myopic astigmatism with 1-year follow-up: clinical outcome and change in higher order aberrations. Ophthalmology 2004;111:2175-85.

171. Buhren J, Kohnen T. Factors affecting the change in lower-order and higher-order aberrations after wavefront-guided laser in situ keratomileusis for myopia with the Zyoptix 3.1 system. J Cataract Refract Surg 2006;32:1166-74.

172. Chalita MR, Chavala S, Xu M, Krueger RR. Wavefront analysis in post-LASIK eyes and its correlation with visual symptoms, refraction, and topography. Ophthalmology 2004;111:447-53.

173. Kohnen T, Mahmoud K, Buhren J. Comparison of corneal higher-order aberrations induced by myopic and hyperopic LASIK. Ophthalmology 2005;112:1692.

174. McCormick GJ, Porter J, Cox IG, MacRae S. Higher-order aberrations in eyes with irregular corneas after laser refractive surgery. Ophthalmology 2005;112:1699-709.

175. Oshika T, Klyce SD, Applegate RA, Howland HC, El Danasoury MA. Comparison of corneal wavefront aberrations after photorefractive keratectomy and laser in situ keratomileusis. Am J Ophthalmol 1999;127:1-7.

176. Jabbur NS, Kraff C. Wavefront-guided laser in situ keratomileusis using the WaveScan system for correction of low to moderate myopia with astigmatism: 6-month results in 277 eyes. J Cataract Refract Surg 2005;31:1493-501.

177. Kim TI, Yang SJ, Tchah H. Bilateral comparison of wavefront-guided versus conventional laser in situ keratomileusis with Bausch and Lomb Zyoptix. J Refract Surg 2004;20:432-8.

178. Waheed S, Krueger RR. Update on customized excimer ablations: recent developments reported in 2002. Curr Opin Ophthalmol 2003;14:198-202. 
179. Zhou C, Chai X, Yuan L, He Y, Jin M, Ren Q. Corneal higher-order aberrations after customized aspheric ablation and conventional ablation for myopic correction. Curr Eye Res 2007;32:431-8.

180. Du CX, Yang YB, Shen Y, Wang Y, Dougherty PJ. Bilateral comparison of conventional versus topographic-guided customized ablation for myopic LASIK with the NIDEK EC-5000. J Refract Surg 2006;22:642-6.

181. Farooqui MA, Al-Muammar AR. Topography-guided CATz versus conventional LASIK for myopia with the NIDEK EC-5000: A bilateral eye study. J Refract Surg 2006;22:741-5.

182. Kermani O, Schmiedt K, Oberheide U, Gerten G. Topographic- and wavefrontguided customized ablations with the NIDEK-EC5000CXII in LASIK for myopia. J Refract Surg 2006;22:754-63.

183. Baikoff G, Arne JL, Bokobza Y, et al. Angle-fixated anterior chamber phakic intraocular lens for myopia of -7 to -19 diopters. J Refract Surg 1998;14:282-93.

184. Leccisotti A. Traumatic pupillary capture of the haptic of an angle-supported phakic intraocular lens. J Cataract Refract Surg 2006;32:2133-4.

185. Leccisotti A. Iridocyclitis associated with angle-supported phakic intraocular lenses. J Cataract Refract Surg 2006;32:1007-10.

186. Alio JL, Ruiz-Moreno JM, Artola A. Retinal detachment as a potential hazard in surgical correction of severe myopia with phakic anterior chamber lenses. Am J Ophthalmol 1993;115:145-8.

187. Perez-Santonja JJ, Alio JL, Jimenez-Alfaro I, Zato MA. Surgical correction of severe myopia with an angle-supported phakic intraocular lens. J Cataract Refract Surg 2000;26:1288-302.

188. Perez-Santonja JJ, Iradier MT, Sanz-Iglesias L, Serrano JM, Zato MA. Endothelial changes in phakic eyes with anterior chamber intraocular lenses to correct high myopia. J Cataract Refract Surg 1996;22:1017-22.

189. Perez-Santonja JJ, Hernandez JL, Benitez del Castillo JM, Rodriguez-Bermejo C, Zato MA. Fluorophotometry in myopic phakic eyes with anterior chamber intraocular lenses to correct severe myopia. Am J Ophthalmol 1994;118:316-21.

190. Perez-Santonja JJ, Ruiz-Moreno JM, de la Hoz F, Giner-Gorriti C, Alio JL. Endophthalmitis after phakic intraocular lens implantation to correct high myopia. J Cataract Refract Surg 1999;25:1295-8.

191. Alio JL, de la Hoz F, Perez-Santonja JJ, Ruiz-Moreno JM, Quesada JA. Phakic anterior chamber lenses for the correction of myopia: a 7-year cumulative analysis of complications in 263 cases. Ophthalmology 1999;106:458-66.

192. Allemann N, Chamon W, Tanaka HM, et al. Myopic angle-supported intraocular lenses: two-year follow-up. Ophthalmology 2000;107:1549-54.

193. Leccisotti A, Fields SV. Clinical results of ZSAL-4 angle-supported phakic intraocular lenses in 190 myopic eyes. J Cataract Refract Surg 2005;31:318-23.

194. Kohnen T, Baumeister M, Cichocki M. [Intraocular lenses for the correction of refraction errors. Part 1: phakic anterior chamber lenses]. Ophthalmologe 2005;102:1003-7; quiz 1018. 
195. Coullet J, Mahieu L, Malecaze F, et al. Severe endothelial cell loss following uneventful angle-supported phakic intraocular lens implantation for high myopia. J Cataract Refract Surg 2007;33:1477-81.

196. Ruiz-Moreno JM, Alio JL. Incidence of retinal disease following refractive surgery in 9,239 eyes. J Refract Surg 2003;19:534-47.

197. Asano-Kato N, Toda I, Hori-Komai Y, et al. Experience with the Artisan phakic intraocular lens in Asian eyes. J Cataract Refract Surg 2005;31:910-5.

198. Coullet J, Guell JL, Fournie P, et al. Iris-supported phakic lenses (rigid vs foldable version) for treating moderately high myopia: randomized paired eye comparison. Am J Ophthalmol 2006;142:909-16.

199. Maloney RK, Nguyen LH, John ME. Artisan phakic intraocular lens for myopia:shortterm results of a prospective, multicenter study. Ophthalmology 2002;109:1631-41.

200. Budo C, Hessloehl JC, Izak M, et al. Multicenter study of the Artisan phakic intraocular lens. J Cataract Refract Surg 2000;26:1163-71.

201. Landesz M, van Rij G, Luyten G. Iris-claw phakic intraocular lens for high myopia. J Refract Surg 2001;17:634-40.

202. Menezo JL, Peris-Martinez C, Cisneros AL, Martinez-Costa R. Phakic intraocular lenses to correct high myopia: Adatomed, Staar, and Artisan. J Cataract Refract Surg 2004;30:33-44.

203. Menezo JL, Avino JA, Cisneros A, Rodriguez-Salvador V, Martinez-Costa R. Iris claw phakic intraocular lens for high myopia. J Refract Surg 1997;13:545-55.

204. Menezo JL, Cisneros AL, Rodriguez-Salvador V. Endothelial study of iris-claw phakic lens: four year follow-up. J Cataract Refract Surg 1998;24:1039-49.

205. Gierek-Ciaciura S, Gierek-Lapinska A, Ochalik K, Mrukwa-Kominek E. Correction of high myopia with different phakic anterior chamber intraocular lenses: ICARE angle-supported lens and Verisyse iris-claw lens. Graefes Arch Clin Exp Ophthalmol 2007;245:1-7.

206. Senthil S, Reddy KP. A retrospective analysis of the first Indian experience on Artisan phakic intraocular lens. Indian J Ophthalmol 2006;54:251-5.

207. Lifshitz T, Levy J, Aizenman I, Klemperer I, Levinger S. Artisan phakic intraocular lens for correcting high myopia. Int Ophthalmol 2004;25:233-8.

208. Stulting RD, John ME, Maloney RK, Assil KK, Arrowsmith PN, Thompson VM. Three-year results of Artisan/Verisyse phakic intraocular lens implantation. Results of the United States Food And Drug Administration clinical trial. Ophthalmology 2008;115:464-472 e1.

209. Dick HB, Alio J, Bianchetti M, et al. Toric phakic intraocular lens: European multicenter study. Ophthalmology 2003;110:150-62.

210. Alio JL, Mulet ME, Gutierrez R, Galal A. Artisan toric phakic intraocular lens for correction of astigmatism. J Refract Surg 2005;21:324-31.

211. Guell JL, Vazquez M, Malecaze F, et al. Artisan toric phakic intraocular lens for the correction of high astigmatism. Am J Ophthalmol 2003;136:442-7.

212. Tehrani M, Dick HB. Short-term follow-up after implantation of a foldable iris-fixated intraocular lens in phakic eyes. Ophthalmology 2005;112:2189-95. 
213. Dick HB, Aliyeva S, Tehrani M. Change in pupil size after implantation of an irisfixated toric phakic intraocular lens. J Cataract Refract Surg 2005;31:302-7.

214. Benedetti S, Casamenti V, Marcaccio L, Brogioni C, Assetto V. Correction of myopia of 7 to 24 diopters with the Artisan phakic intraocular lens: two-year follow-up. J Refract Surg 2005;21:116-26.

215. Coppens JE, van den Berg TJ, Budo CJ. Biometry of phakic intraocular lens using Scheimpflug photography. J Cataract Refract Surg 2005;31:1904-14.

216. Baumeister M, Buhren J, Kohnen T. Position of angle-supported, iris-fixated, and ciliary sulcus-implanted myopic phakic intraocular lenses evaluated by Scheimpflug photography. Am J Ophthalmol 2004;138:723-31.

217. Kleinmann G, Apple DJ, Mackool RJ. Recurrent iritis after implantation of an irisfixated phakic intraocular lens for the correction of myopia Case report and clinicopathologic correlation. J Cataract Refract Surg 2006;32:1385-7.

218. Pop M, Payette Y. Initial results of endothelial cell counts after Artisan lens for phakic eyes: an evaluation of the United States Food and Drug Administration Ophtec Study. Ophthalmology 2004;111:309-17.

219. Chang DH, Davis EA. Phakic intraocular lenses. Curr Opin Ophthalmol 2006;17:99-104.

220. Diab F, Al-Rashaed S, Al-Motowa S. Endophthalmitis after Artisan phakic intraocular lens implantation for correction of high myopia. J Refract Surg 2006;22:332-3.

221. Moshirfar M, Whitehead G, Beutler BC, Mamalis N. Toxic anterior segment syndrome after Verisyse iris-supported phakic intraocular lens implantation. J Cataract Refract Surg 2006;32:1233-7.

222. Marinho A, Pinto MC, Vaz F. Phakic intraocular lenses: which to choose. Curr Opin Ophthalmol 2000;11:280-8.

223. Alio JL, Mulet ME, Shalaby AM. Artisan phakic iris claw intraocular lens for high primary and secondary hyperopia. J Refract Surg 2002;18:697-707.

224. Baikoff G, Bourgeon G, Jodai HJ, Fontaine A, Lellis FV, Trinquet L. Pigment dispersion and Artisan phakic intraocular lenses: crystalline lens rise as a safety criterion. J Cataract Refract Surg 2005;31:674-80.

225. Tahzib NG, Eggink FA, Frederik PM, Nuijts RM. Recurrent intraocular inflammation after implantation of the Artiflex phakic intraocular lens for the correction of high myopia. J Cataract Refract Surg 2006;32:1388-91.

226. Boxer Wachler BS, Huynh VN, El-Shiaty AF, Goldberg D. Evaluation of corneal functional optical zone after laser in situ keratomileusis. J Cataract Refract Surg 2002;28:948-53.

227. Tahzib NG, Bootsma SJ, Eggink FA, Nuijts RM. Functional outcome and patient satisfaction after artisan phakic intraocular lens implantation for the correction of myopia. Am J Ophthalmol 2006;142:31-39.

228. Moshirfar M, Holz HA, Davis DK. Two-year follow-up of the Artisan/Verisyse irissupported phakic intraocular lens for the correction of high myopia. J Cataract Refract Surg 2007;33:1392-7. 
229. Bootsma SJ, Tahzib NG, Eggink FA, de Brabander J, Nuijts RM. Evaluation of pupil dynamics after implantation of artisan phakic intraocular lenses. J Refract Surg 2006;22:367-71.

230. Atchison DA, Scott DH. The Stiles-Crawford effect and subjective measurement of aberrations. Vision Res 2002;42:1089-102.

231. Bourne WM, Nelson LR, Hodge DO. Central corneal endothelial cell changes over a ten-year period. Invest Ophthalmol Vis Sci 1997;38:779-82.

232. Benedetti S, Casamenti V, Benedetti M. Long-term endothelial changes in phakic eyes after Artisan intraocular lens implantation to correct myopia: five-year study. J Cataract Refract Surg 2007;33:784-90.

233. Saxena R, Boekhoorn SS, Mulder PG, Noordzij B, Rij GV, Luyten GP. Long-term Follow-up of Endothelial Cell Change after Artisan Phakic Intraocular Lens Implantation. Ophthalmology 2007.

234. Tehrani M, Dick HB. Endothelial cell loss after toric iris-fixated phakic intraocular lens implantation: three-year follow-up. J Refract Surg 2007;23:172-7.

235. Kohnen T, Baumeister M, Magdowski G. Scanning electron microscopic characteristics of phakic intraocular lenses. Ophthalmology 2000;107:934-9.

236. Konomi K, Zhu C, Harris D, Joyce NC. Comparison of the proliferative capacity of human corneal endothelial cells from the central and peripheral areas. Invest Ophthalmol Vis Sci 2005;46:4086-91.

237. Whikehart DR, Parikh CH, Vaughn AV, Mishler K, Edelhauser HF. Evidence suggesting the existence of stem cells for the human corneal endothelium. Mol Vis 2005;11:816-24.

238. Odenthal MT, Gan IM, Oosting J, Kijlstra A, Beekhuis WH. Long-term changes in corneal endothelial morphology after discontinuation of low gas-permeable contact lens wear. Cornea 2005;24:32-8.

239. Edelhauser HF, Sanders DR, Azar R, Lamielle H. Corneal endothelial assessment after ICL implantation. J Cataract Refract Surg 2004;30:576-83.

240. Lim R, Mitchell P, Cumming RG. Refractive associations with cataract: the Blue Mountains Eye Study. Invest Ophthalmol Vis Sci 1999;40:3021-6.

241. Tehrani M, Dick HB. Iris-fixated toric phakic intraocular lens: Three-year follow-up. J Cataract Refract Surg 2006;32:1301-6.

242. Brunette I, Bueno JM, Harissi-Dagher M, Parent M, Podtetenev M, Hamam H. Optical quality of the eye with the Artisan phakic lens for the correction of high myopia. Optom Vis Sci 2003;80:167-74.

243. Tehrani M, Dick HB. Changes in higher-order aberrations after implantation of a foldable iris-claw lens in myopic phakic eyes. J Cataract Refract Surg 2006;32:250-4.

244. Chung SH, Lee SJ, Lee HK, Seo KY, Kim EK. Changes in higher order aberrations and contrast sensitivity after implantation of a phakic artisan intraocular lens. Ophthalmologica 2007;221:167-72.

245. Chandhrasri S, Knorz MC. Comparison of higher order aberrations and contrast sensitivity after LASIK, Verisyse phakic IOL, and Array multifocal IOL. J Refract Surg 2006;22:231-6. 
246. Brauweiler PH, Wehler T, Busin M. High incidence of cataract formation after implantation of a silicone posterior chamber lens in phakic, highly myopic eyes. Ophthalmology 1999;106:1651-5.

247. Mastropasqua L, Toto L, Nubile M, Falconio G, Ciancaglini M. Long-term complications of bilateral posterior chamber phakic intraocular lens implantation. J Cataract Refract Surg 2004;30:901-4.

248. Pesando PM, Ghiringhello MP, Tagliavacche P. Posterior chamber collamer phakic intraocular lens for myopia and hyperopia. J Refract Surg 1999;15:415-23.

249. Sanders DR, Vukich JA, Doney K, Gaston M. U.S. Food and Drug Administration clinical trial of the Implantable Contact Lens for moderate to high myopia. Ophthalmology 2003;110:255-66.

250. Zaldivar R, Davidorf JM, Oscherow S. Posterior chamber phakic intraocular lens for myopia of -8 to -19 diopters. J Refract Surg 1998;14:294-305.

251. Brown DC, Grabow HB, Martin RG, et al. Staar Collamer intraocular lens: clinical results from the phase I FDA core study. J Cataract Refract Surg 1998;24:1032-8.

252. Brown DC, Ziemba SL. Collamer intraocular lens: clinical results from the US FDA core study. J Cataract Refract Surg 2001;27:833-40.

253. Assetto V, Benedetti S, Pesando P. Collamer intraocular contact lens to correct high myopia. J Cataract Refract Surg 1996;22:551-6.

254. Uusitalo RJ, Aine E, Sen NH, Laatikainen L. Implantable contact lens for high myopia. J Cataract Refract Surg 2002;28:29-36.

255. Jimenez-Alfaro I, Benitez del Castillo JM, Garcia-Feijoo J, Gil de Bernabe JG, Serrano de La Iglesia JM. Safety of posterior chamber phakic intraocular lenses for the correction of high myopia: anterior segment changes after posterior chamber phakic intraocular lens implantation. Ophthalmology 2001;108:90-9.

256. Pineda-Fernandez A, Jaramillo J, Vargas J, Jaramillo M, Jaramillo J, Galindez A. Phakic posterior chamber intraocular lens for high myopia. J Cataract Refract Surg 2004;30:2277-83.

257. Fink AM, Gore C, Rosen E. Cataract development after implantation of the Staar Collamer posterior chamber phakic lens. J Cataract Refract Surg 1999;25:278-82.

258. Gonvers M, Bornet C, Othenin-Girard P. Implantable contact lens for moderate to high myopia: relationship of vaulting to cataract formation. J Cataract Refract Surg 2003;29:918-24.

259. Lackner B, Pieh S, Schmidinger G, et al. Outcome after treatment of ametropia with implantable contact lenses. Ophthalmology 2003;110:2153-61.

260. Sanchez-Galeana CA, Smith RJ, Sanders DR, et al. Lens opacities after posterior chamber phakic intraocular lens implantation. Ophthalmology 2003;110:781-5.

261. Gonvers M, Othenin-Girard P, Bornet C, Sickenberg M. Implantable contact lens for moderate to high myopia: short-term follow-up of 2 models. J Cataract Refract Surg 2001;27:380-8.

262. Trindade F, Pereira F. Cataract formation after posterior chamber phakic intraocular lens implantation. J Cataract Refract Surg 1998;24:1661-3. 
263. Lackner B, Pieh S, Schmidinger G, et al. Long-term results of implantation of phakic posterior chamber intraocular lenses. J Cataract Refract Surg 2004;30:2269-76.

264. Sanchez-Galeana CA, Zadok D, Montes M, Cortes MA, Chayet AS. Refractory intraocular pressure increase after phakic posterior chamber intraocular lens implantation. Am J Ophthalmol 2002;134:121-3.

265. Garcia-Feijoo J, Hernandez-Matamoros JL, Castillo-Gomez A, et al. Secondary glaucoma and severe endothelial damage after silicone phakic posterior chamber intraocular lens implantation. J Cataract Refract Surg 2004;30:1786-9.

266. Brandt JD, Mockovak ME, Chayet A. Pigmentary dispersion syndrome induced by a posterior chamber phakic refractive lens. Am J Ophthalmol 2001;131:260-3.

267. Smallman DS, Probst L, Rafuse PE. Pupillary block glaucoma secondary to posterior chamber phakic intraocular lens implantation for high myopia. J Cataract Refract Surg 2004;30:905-7.

268. Pop M, Payette Y, Mansour M. Predicting sulcus size using ocular measurements. J Cataract Refract Surg 2001;27:1033-8.

269. Werner L, Izak AM, Pandey SK, Apple DJ, Trivedi RH, Schmidbauer JM. Correlation between different measurements within the eye relative to phakic intraocular lens implantation. J Cataract Refract Surg 2004;30:1982-8.

270. Choi KH, Chung SE, Chung TY, Chung ES. Ultrasound biomicroscopy for determining visian implantable contact lens length in phakic IOL implantation. J Refract Surg 2007;23:362-7.

271. Dejaco-Ruhswurm I, Scholz U, Pieh S, et al. Long-term endothelial changes in phakic eyes with posterior chamber intraocular lenses. J Cataract Refract Surg 2002;28:1589-93.

272. Thompson RW, Jr., Price MO, Bowers PJ, Price FW, Jr. Long-term graft survival after penetrating keratoplasty. Ophthalmology 2003;110:1396-402.

273. Bertelmann E, Pleyer U, Rieck P. Risk factors for endothelial cell loss post-keratoplasty. Acta Ophthalmol Scand 2006;84:766-70.

274. Patel SV, Hodge DO, Bourne WM. Corneal endothelium and postoperative outcomes 15 years after penetrating keratoplasty. Am J Ophthalmol 2005;139:311-9.

275. Ing JJ, Ing HH, Nelson LR, Hodge DO, Bourne WM. Ten-year postoperative results of penetrating keratoplasty. Ophthalmology 1998;105:1855-65.

276. Muraine M, Sanchez C, Watt L, Retout A, Brasseur G. Long-term results of penetrating keratoplasty. A 10-year-plus retrospective study. Graefes Arch Clin Exp Ophthalmol 2003;241:571-6.

277. Price MO, Thompson RW, Jr., Price FW, Jr. Risk factors for various causes of failure in initial corneal grafts. Arch Ophthalmol 2003;121:1087-92.

278. Inoue K, Amano S, Oshika T, Sawa M, Tsuru T. A 10-year review of penetrating keratoplasty. Jpn J Ophthalmol 2000;44:139-45.

279. Jonas JB, Rank RM, Budde WM. Immunologic graft reactions after allogenic penetrating keratoplasty. Am J Ophthalmol 2002;133:437-43.

280. Chang DH, Hardten DR. Refractive surgery after corneal transplantation. Curr Opin Ophthalmol 2005;16:251-5. 
281. Riddle HK, Jr., Parker DA, Price FW, Jr. Management of postkeratoplasty astigmatism. Curr Opin Ophthalmol 1998;9:15-28.

282. van Rij G, Cornell FM, Waring GO, 3rd, Wilson LA, Beekhuis WH. Postoperative astigmatism after central vs eccentric penetrating keratoplasties. Am J Ophthalmol 1985;99:317-20.

283. Kerenyi A, Suveges I. Corneal topographic results after eccentric, biconvex penetrating keratoplasty. J Cataract Refract Surg 2003;29:752-6.

284. Karabatsas CH, Cook SD, Sparrow JM. Proposed classification for topographic patterns seen after penetrating keratoplasty. Br J Ophthalmol 1999;83:403-9.

285. Brooks SE, Johnson D, Fischer N. Anisometropia and binocularity. Ophthalmology 1996;103:1139-43.

286. Eggink FA, Nuijts RM. A new technique for rigid gas permeable contact lens fitting following penetrating keratoplasty. Acta Ophthalmol Scand 2001;79:245-50.

287. Geerards AJ, Vreugdenhil W, Khazen A. Incidence of rigid gas-permeable contact lens wear after keratoplasty for keratoconus. Eye Contact Lens 2006;32:207-10.

288. Pullum K, Buckley R. Therapeutic and ocular surface indications for scleral contact lenses. Ocul Surf 2007;5:40-8.

289. Pullum KW, Whiting MA, Buckley RJ. Scleral contact lenses: the expanding role. Cornea 2005;24:269-77.

290. Visser ES, Visser R, van Lier HJ, Otten HM. Modern scleral lenses part I: clinical features. Eye Contact Lens 2007;33:13-20.

291. Faktorovich EG, Maloney RK, Price FW, Jr. Effect of astigmatic keratotomy on spherical equivalent: results of the Astigmatism Reduction Clinical Trial. Am J Ophthalmol 1999;127:260-9.

292. Seitz B, Naumann GO. Limbus-parallel keratotomies and compression sutures in excessive astigmatism after penetrating keratoplasty. Ger J Ophthalmol 1993;2:42-50.

293. Hardten DR, Lindstrom RL. Surgical correction of refractive errors after penetrating keratoplasty. Int Ophthalmol Clin 1997;37:1-35.

294. Wilkins MR, Mehta JS, Larkin DF. Standardized arcuate keratotomy for postkeratoplasty astigmatism. J Cataract Refract Surg 2005;31:297-301.

295. Poole TR, Ficker LA. Astigmatic keratotomy for post-keratoplasty astigmatism. J Cataract Refract Surg 2006;32:1175-9.

296. Koay PY, McGhee CN, Crawford GJ. Effect of a standard paired arcuate incision and augmentation sutures on postkeratoplasty astigmatism. J Cataract Refract Surg 2000;26:553-61.

297. Hjortdal JO, Ehlers N. Paired arcuate keratotomy for congenital and post-keratoplasty astigmatism. Acta Ophthalmol Scand 1998;76:138-41.

298. Hovding G. Transverse keratotomy in postkeratoplasty astigmatism. Acta Ophthalmol (Copenh) 1994;72:464-8.

299. Belmont SC, Lazzaro DR, Muller JW, Troutman RC. Combined wedge resection and relaxing incisions for astigmatism after penetrating keratoplasty. J Refract Surg 1995;11:472-6. 
300. Troutman RC. Corneal wedge resections and relaxing incisions for postkeratoplasty astigmatism. Int Ophthalmol Clin 1983;23:161-8.

301. Ghanem RC, Azar DT. Femtosecond-laser arcuate wedge-shaped resection to correct high residual astigmatism after penetrating keratoplasty. J Cataract Refract Surg 2006;32:1415-9.

302. Bilgihan K, Ozdek SC, Akata F, Hasanreisoglu B. Photorefractive keratectomy for post-penetrating keratoplasty myopia and astigmatism. J Cataract Refract Surg 2000;26:1590-5.

303. Yoshida K, Tazawa Y, Demong TT. Refractive results of post penetrating keratoplasty photorefractive keratectomy. Ophthalmic Surg Lasers 1999;30:354-9.

304. Amm M, Duncker GI, Schroder E. Excimer laser correction of high astigmatism after keratoplasty. J Cataract Refract Surg 1996;22:313-7.

305. Bansal AK. Photoastigmatic refractive keratectomy for correction of astigmatism after keratoplasty. J Refract Surg 1999;15:S243-5.

306. Lazzaro DR, Haight DH, Belmont SC, Gibralter RP, Aslanides IM, Odrich MG. Excimer laser keratectomy for astigmatism occurring after penetrating keratoplasty. Ophthalmology 1996;103:458-64.

307. Tuunanen TH, Ruusuvaara PJ, Uusitalo RJ, Tervo TM. Photoastigmatic keratectomy for correction of astigmatism in corneal grafts. Cornea 1997;16:48-53.

308. Alessio G, Boscia F, La Tegola MG, Sborgia C. Corneal interactive programmed topographic ablation customized photorefractive keratectomy for correction of postkeratoplasty astigmatism. Ophthalmology 2001;108:2029-37.

309. Vigo L, Scandola E, Carones F. Scraping and mitomycin C to treat haze and regression after photorefractive keratectomy for myopia. J Refract Surg 2003;19:449-54.

310. Solomon R, Donnenfeld ED, Perry HD. Photorefractive keratectomy with mitomycin $\mathrm{C}$ for the management of a LASIK flap complication following a penetrating keratoplasty. Cornea 2004;23:403-5.

311. Rajan MS, O‘Brart DP, Patel P, Falcon MG, Marshall J. Topography-guided customized laser-assisted subepithelial keratectomy for the treatment of postkeratoplasty astigmatism. J Cataract Refract Surg 2006;32:949-57.

312. Webber SK, Lawless MA, Sutton GL, Rogers CM. LASIK for post penetrating keratoplasty astigmatism and myopia. Br J Ophthalmol 1999;83:1013-8.

313. Kwitko S, Marinho DR, Rymer S, Ramos Filho S. Laser in situ keratomileusis after penetrating keratoplasty. J Cataract Refract Surg 2001;27:374-9.

314. Forseto AS, Francesconi CM, Nose RA, Nose W. Laser in situ keratomileusis to correct refractive errors after keratoplasty. J Cataract Refract Surg 1999;25:479-85.

315. Arenas E, Maglione A. Laser in situ keratomileusis for astigmatism and myopia after penetrating keratoplasty. J Refract Surg 1997;13:27-32.

316. Donnenfeld ED, Kornstein HS, Amin A, et al. Laser in situ keratomileusis for correction of myopia and astigmatism after penetrating keratoplasty. Ophthalmology 1999;106:1966-74; discussion 1974-5.

317. Nassaralla BR, Nassaralla JJ. Laser in situ keratomileusis after penetrating keratoplasty. J Refract Surg 2000;16:431-7. 
318. Rashad KM. Laser in situ keratomileusis for correction of high astigmatism after penetrating keratoplasty. J Refract Surg 2000;16:701-10.

319. Lima GdS, Moreira H, Wahab SA. Laser in situ keratomileusis to correct myopia, hypermetropia and astigmatism after penetrating keratoplasty for keratoconus: a series of 27 cases. Can J Ophthalmol 2001;36:391-6; discussion 396-7.

320. Malecha MA, Holland EJ. Correction of myopia and astigmatism after penetrating keratoplasty with laser in situ keratomileusis. Cornea 2002;21:564-9.

321. Barraquer CC, Rodriguez-Barraquer T. Five-year results of laser in-situ keratomileusis (LASIK) after penetrating keratoplasty. Cornea 2004;23:243-8.

322. Cosar CB, Acar S. Topography-guided LASIK with the wavelight laser after penetrating keratoplasty. J Refract Surg 2006;22:716-9.

323. Vajpayee RB, Sharma N, Sinha R, Bhartiya P, Titiyal JS, Tandon R. Laser in-situ keratomileusis after penetrating keratoplasty. Surv Ophthalmol 2003;48:503-14.

324. Donnenfeld ED, Solomon R, Biser S. Laser in situ keratomileusis after penetrating keratoplasty. Int Ophthalmol Clin 2002;42:67-87.

325. Hardten DR, Chittcharus A, Lindstrom RL. Long term analysis of LASIK for the correction of refractive errors after penetrating keratoplasty. Cornea 2004;23:479-89.

326. Guell JL, Gris O, de Muller A, Corcostegui B. LASIK for the correction of residual refractive errors from previous surgical procedures. Ophthalmic Surg Lasers 1999;30:341-9.

327. Solomon R, Donnenfeld ED, Perry HD, Nirankari VS. Post-LASIK corneal flap displacement following penetrating keratoplasty for bullous keratopathy. Cornea $2005 ; 24: 874-8$.

328. Bissen-Miyajima H, Nakamura K, Kaido M, Shimmura S, Tsubota K. Role of the endothelial pump in flap adhesion after laser in situ keratomileusis. J Cataract Refract Surg 2004;30:1989-92.

329. Lee GA, Perez-Santonja JJ, Maloof A, Ficker LA, Dart JK. Effects of lamellar keratotomy on postkeratoplasty astigmatism. Br J Ophthalmol 2003;87:432-5.

330. Ranchod TM, McLeod SD. Wound dehiscence in a patient with keratoconus after penetrating keratoplasty and LASIK. Arch Ophthalmol 2004;122:920-1.

331. Alio JL, Javaloy J, Osman AA, Galvis V, Tello A, Haroun HE. Laser in situ keratomileusis to correct post-keratoplasty astigmatism; 1-step versus 2-step procedure. J Cataract Refract Surg 2004;30:2303-10.

332. Busin M, Zambianchi L, Garzione F, Maucione V, Rossi S. Two-stage laser in situ keratomileusis to correct refractive errors after penetrating keratoplasty. J Refract Surg 2003;19:301-8.

333. Colin J, Abdelkefi A. Two-step laser in situ keratomileusis to correct high astigmatism after corneal autograft. J Cataract Refract Surg 2006;32:1966-7.

334. Mularoni A, Laffi GL, Bassein L, Tassinari G. Two-step LASIK with topographyguided ablation to correct astigmatism after penetrating keratoplasty. J Refract Surg 2006;22:67-74. 
335. Kohnen T, Buhren J. Corneal first-surface aberration analysis of the biomechanical effects of astigmatic keratotomy and a microkeratome cut after penetrating keratoplasty. J Cataract Refract Surg 2005;31:185-9.

336. Knorz MC, Jendritza B. Topographically-guided laser in situ keratomileusis to treat corneal irregularities. Ophthalmology 2000;107:1138-43.

337. Jankov MR, 2nd, Panagopoulou SI, Tsiklis NS, Hajitanasis GC, Aslanides M, Pallikaris G. Topography-guided treatment of irregular astigmatism with the wavelight excimer laser. J Refract Surg 2006;22:335-44.

338. Morales AJ, Zadok D, Mora-Retana R, Martinez-Gama E, Robledo NE, Chayet AS. Intraoperative mitomycin and corneal endothelium after photorefractive keratectomy. Am J Ophthalmol 2006;142:400-4.

339. Rajan MS, O‘Brart DP, Patmore A, Marshall J. Cellular effects of mitomycinC on human corneas after photorefractive keratectomy. J Cataract Refract Surg 2006;32:1741-7.

340. Nuijts RM, Abhilakh Missier KA, Nabar VA, Japing WJ. Artisan toric lens implantation for correction of postkeratoplasty astigmatism. Ophthalmology 2004;111:1086-94.

341. Moshirfar M, Barsam CA, Parker JW. Implantation of an Artisan phakic intraocular lens for the correction of high myopia after penetrating keratoplasty. J Cataract Refract Surg 2004;30:1578-81.

342. Moshirfar M, Feilmeier MR, Kang PC. Implantation of verisyse phakic intraocular lens to correct myopic refractive error after penetrating keratoplasty in pseudophakic eyes. Cornea 2006;25:107-11.

343. Bourne WM, McLaren JW. Clinical responses of the corneal endothelium. Exp Eye Res 2004;78:561-72.

344. Bourne WM, Nelson LR, Hodge DO. Continued endothelial cell loss ten years after lens implantation. Ophthalmology 1994;101:1014-22; discussion 1022-3.

345. Viestenz A, Kuchle M, Seitz B, Langenbucher A. [Toric intraocular lenses for correction of persistent corneal astigmatism after penetrating keratoplasty]. Ophthalmologe 2005;102:148-52.

346. McMullan TF, Goldsmith C, Illingworth CD. Toric posterior chamber (in-the-bag) intraocular lens implantation to correct postpenetrating keratoplasty astigmatism. Eye 2007;21:150-2.

347. Kersey JP, O'Donnell A, Illingworth CD. Cataract surgery with toric intraocular lenses can optimize uncorrected postoperative visual acuity in patients with marked corneal astigmatism. Cornea 2007;26:133-5.

348. Buchwald HJ, Lang GK. [Cataract surgery with implantation of toric silicone lenses for severe astigmatism after keratoplasty]. Klin Monatsbl Augenheilkd 2004;221:489-94. 


\section{Comparison of two pupillometers in determining pupil size for refractive surgery}

Bootsma SJ, Tahzib NG, Eggink FAGJ, Nuijts RMMA.

Acta Ophthalmol Scand. 2007 May;85(3):324-8. 


\section{ABSTRACT}

Purpose: To compare a handheld and a digital pupillometer in determining pupil size in a population of refractive surgery candidates (group 1) and after Artisan phakic intraocular lens (PIOL) implantation for correction of myopia (group 2).

Methods: The pupil size was measured with the Colvard and Procyon pupillometer in 121 eyes of group 1 and in 83 eyes of group 2, respectively.

Pupil sizes measured with Colvard were compared to the scotopic, mesopic-low- and mesopic-high measurements of the Procyon pupillometer in both groups. Analysis of comparison between pupil measurements was performed according to methods described by Bland and Altman.

Results: The mean Colvard scotopic pupil diameter, scotopic, mesopic-low and mesopichigh Procyon pupil diameters were $5.86 \pm .81 \mathrm{~mm}, 6.42 \pm .88 \mathrm{~mm}, 5.55 \pm .95 \mathrm{~mm}$ and $4.21 \pm .73 \mathrm{~mm}$ in group 1 and $5.32 \pm .67 \mathrm{~mm}, 6.14 \pm .81 \mathrm{~mm}, 5.33 \pm .78 \mathrm{~mm}$ and $4.02 \pm$ $.55 \mathrm{~mm}$ in group 2, respectively. The Colvard diameter compared most favourably with the Procyon mesopic-low diameter (group 2, $P=.78$ )

Conclusions: Measurements of pupil diameter with the Colvard pupillometer correlated best with measurements taken by the Procyon pupillometer under standardized mesopic-low light conditions. We believe that digital binocular infrared pupillometry is advantageous for standardized measurement of the pupil size. 


\section{INTRODUCTION}

Pupil size as an influential factor for the development of night vision complaints (NVCs) including halos, starbursts and glare after refractive surgery has been under great discussion lately (Fan-Paul et al. 2002). Although many authors suggest that a disparity between the pupil size measured under dim light conditions and the optical zone size of the laser ablation or the PIOL may be responsible for subjective NVCs, recent reports argue the role of the pupil size in the pathophysiology of NVCs (Bailey et al. 2003; Klyce 2004; Pop \& Payette 2004; Probst 2004; Schallhorn et al. 2003).

Methods for measuring pupil size over the years have included the use of pupil charts, photo cameras, and more recently, digital and handheld infrared pupillometers (Boxer Wachler \& Krueger 2000; Colvard 1998; Kohnen et al. 2003; Pop et al. 2002; Schnitzler et al. 2000). To study potential correlations between pupil size and NVCs the measurement of the pupil size should reflect real-time situations and should be performed under standardized illumination conditions. The two most popular instruments for measuring pupil size under dim light conditions are currently the Colvard pupillometer and the Procyon pupillometer (Colvard 1998; Kohnen et al. 2003; Schnitzler et al. 2000).

The purpose of this study was to compare the Colvard infrared pupillometer and the Procyon pupillometer in determining pupil size in a population of refractive surgery candidates and after Artisan PIOL implantation.

\section{PATIENTS AND METHODS}

The Artisan PIOL has a convex-concave optic with either a 6-mm (for intraocular lens powers up to -15.5 diopters (D)) or a $5-\mathrm{mm}$ (for intraocular lens powers from $-16.0 \mathrm{D}$ up to $-24.0 \mathrm{D}$ ) and is available in $0.50 \mathrm{D}$ steps (Ophtec B.V., Groningen, the Netherlands). This single-piece lens is composed of polymethyl methacrylate. The PIOL is iris claw-fixated.

The study consisted of the comparison of pupil size measurements with the Colvard (Oasis Medical, Glendora, CA) and the Procyon (P2000 SA pupillometer, Procyon Instruments Ltd.) pupillometers in two populations: a population of 121 eyes (group 1) selected randomly out of refractive surgery screening candidates and a population of 83 eyes (group 2) after Artisan PIOL implantation. Patients were enrolled at the Academic Centre for Refractive Surgery, University Hospital Maastricht, the Netherlands. The mean age \pm standard deviation (SD) in years of group 1 was $48.8 \pm 9.1$ (range 27 to 61 years) and $43.8 \pm 8.7$ (range 28 to 56 years) for group 2. This study was conducted in accordance with the Helsinki Declaration and informed consent was obtained from all patients. Investigational review board approval was obtained from the Academic Hospital Maastricht, the Netherlands. 
Postoperative pupil diameters in group 2 were obtained 3 months after surgery. Exclusion criteria included iris abnormalities and systemic diseases that might affect pupil function.

\section{Pupil size measurements}

The handheld Colvard pupillometer uses light amplification technology. The patient is asked to fixate on a red light, produced by an IR-LED inside the device while the examiner is able to focus the iris and pupil by moving the pupillometer slightly forward and back. A millimeter ruler is superimposed by a reticule in the device over the image and allows direct measurement. The examiner was instructed to estimate the horizontal pupil diameter size with a precision of 0.25 $\mathrm{mm}$. Surrounding background room illumination of 0.15 lux was measured with a luxmeter.

The Procyon pupillometer is a digital infrared device for binocular simultaneous measurements of pupil diameter at 3 levels of luminance (scotopic [0.04 lux], mesopic-low [0.4 lux], and mesopic-high [4.0 lux]). Infrared light-emitting diodes illuminate the eyes with long-wave light that does not affect pupil size but is recognized by the charge-coupled device camera in the system. For both eyes, 10 images were acquired at each level of luminance, and stored into a computer. The patient looks into the device and fixates on a black spot at a virtual distance of $10 \mathrm{~m}$. Rubber eyecups prevent the illumination level to rise above the adjusted level. The examiner could view the acquired images immediately and distorted images were removed. The mean and SD, and range of scotopic, mesopic-low, and mesopic-high pupil diameters were assessed by the software and displayed as a diagram.

Before each measurement with the Colvard and Procyon devices, a one-minute dark adaptation was taken into account. All Colvard and Procyon measurements were taken by one experienced examiner. Colvard measurements were taken prior to the objective Procyon measurements to minimize influence on readings.

Definitions on scotopic and mesopic levels of illumination were used according to the International Commission on Illumination, with scotopic being less than 0.05 lux, and mesopic between 0.05 and 50 lux (National Physical Laboratory, London, United Kingdom) (Rosen et al. 2002).

Pupil sizes measured with Colvard were compared to each level of illuminance used during the Procyon measurement procedure, in both groups, to compare these devices. Differences between pupil sizes were calculated by subtracting the Procyon measured pupil sizes from the Colvard measured values.

In measuring the pupil size via the cornea and the anterior chamber, one should realize that not the natural pupil is seen, but its image, which is called the entrance pupil. Since in this study we are interested in comparing measured pupil sizes, it is appropriate to use the size of the entrance pupil. However, postoperatively the 
size of the entrance pupil is also changed by the Artisan PIOL since the PIOL is positioned in front of the pupil entrance. Optically, the natural pupil is first imaged by the Artisan PIOL and secondly by the cornea / anterior chamber system. The distance from pupil to lens is given by the back surface sagittal depth called the vault by the manufacturer $(0.799 \mathrm{~mm}$ for powers up to -15.5 $\mathrm{D}$ and $0.733 \mathrm{D}$ for powers $>-15.5 \mathrm{D})$. Since the Artisan PIOL is placed in the anterior chamber fluid (refractive index $=1.336$ ) and is very close to the pupil, the object vergence is very high compared to the effective power of the Artisan PIOL, resulting in a smaller than $1 \%$ change in pupil size. Nevertheless, we have compensated our measured pupil size data for the influence of the Artisan PIOL using the following formula (Obstfeld 1982):

Corrected Entrance Pupil $=\left(1-\frac{\text { vault of Artisan PIOL in mm } \times \text { Dioptric power of Artisan PIOL }}{1336}\right) \times$ Measured pupil size inmm

Statistical analysis

All data were expressed as mean \pm SD. Measured pupil diameters were distributed normally (Kolmogorov-Smirnov test). Paired samples t-tests, and the method of Bland and Altman (Bland \& Altman 1986; Bland \& Altman 2003) were used for analysis. This method compares 2 methods by plotting their means against their differences. P-values less than 0.05 were considered statistically significant.

\section{RESULTS}

In group 1 , the mean \pm SD pupil diameter measured with the Colvard pupillometer and the Procyon pupillometer under scotopic, mesopic-low and mesopichigh light conditions were $5.86 \pm .81 \mathrm{~mm}$, and $6.42 \pm .88 \mathrm{~mm}, 5.55 \pm .95 \mathrm{~mm}$ and $4.21 \pm .73 \mathrm{~mm}$, respectively. For all three light conditions of the Procyon pupillometer there was a significant difference with the Colvard measurements. The lowest mean difference was $.31 \pm .60 \mathrm{~mm}$ for the mesopic-low light condition (Table 1.1, Figures 1.1-1.2).

After Artisan PIOL implantation (group 2) pupil diameters measured with the Colvard pupillometer and the Procyon pupillometer were $5.32 \pm .67 \mathrm{~mm}$ and $6.14 \pm .81 \mathrm{~mm}, 5.33 \pm .78 \mathrm{~mm}$ and $4.02 \pm .55 \mathrm{~mm}$, respectively. Analysis of the mean difference in pupil size after Artisan PIOL implantation, measured with the Colvard and the Procyon pupillometer, showed comparable measurements between Colvard and Procyon under mesopic-low conditions $(-.02 \pm .59 \mathrm{~mm}$, $P=.78)$ 
Table 1.1 Differences in pupil size measured with the Colvard versus the Procyon pupillometer under three light conditions in a population of refractive surgery screening candidates $(\mathrm{n}=121$, group 1$)$

\begin{tabular}{lccc}
\hline Illumination level & $\begin{array}{c}\text { Mean Difference } \\
\pm \mathrm{SD}(\mathrm{mm})\end{array}$ & $\begin{array}{c}\text { 95\% CI^ Mean Differ- } \\
\text { ence Lower/Upper }\end{array}$ & $\begin{array}{c}\text { Significance } \\
(2 \text {-tailed })\end{array}$ \\
\hline Colvard vs. Scotopic & $-0.56 \pm 0.40$ & $-0.63 /-0.49$ & $\mathrm{P}<0.05$ \\
Colvard vs. Mesopic-low & $0.31 \pm 0.60$ & $0.20 / 0.42$ & $\mathrm{P}<0.05$ \\
Colvard vs. Mesopic-high & $1.65 \pm 0.65$ & $1.53 / 1.77$ & $\mathrm{P}<0.05$
\end{tabular}

Table 1.2 Differences in pupil size measured with the Colvard versus the Procyon pupillometer under three light conditions in a population after Artisan PIOL ${ }^{\star}$ implantation $(\mathrm{n}=83$, group 2)

\begin{tabular}{lccc}
\hline Illumination level & $\begin{array}{c}\text { Mean Difference } \\
\pm \mathrm{SD}(\mathrm{mm})\end{array}$ & $\begin{array}{c}95 \% \mathrm{CI}^{\dagger} \text { Mean Differ- } \\
\text { ence Lower/Upper }\end{array}$ & $\begin{array}{c}\text { Significance } \\
(2 \text {-tailed })\end{array}$ \\
\hline Colvard vs. Scotopic & $-0.48 \pm 0.58$ & $-0.97 /-0.71$ & $\mathrm{P}<0.05$ \\
Colvard vs. Mesopic-low & $-0.02 \pm 0.59$ & $-0.15 / 0.11$ & $\mathrm{P}=0.78$ \\
Colvard vs. Mesopic-high & $1.30 \pm 0.66$ & $1.16 / 1.45$ & $\mathrm{P}<0.05$ \\
\hline ^PIOL: Phakic Intraocular Lens; ${ }^{\dagger} \mathrm{CI}$ : Confidence Interval &
\end{tabular}

According to the 95\% Confidence Interval, the systematic difference is less than $0.15 \mathrm{~mm}$ under mesopic-low conditions in group 2. In the first group, this systematic difference is the smallest $(0.42 \mathrm{~mm})$ in the mesopic-low condition as well. Accordingly, Colvard systematically measures $0.63 \mathrm{~mm}$ (group 1) to 0.97 $\mathrm{mm}$ (group 2) less than Procyon scotopic, and $1.45 \mathrm{~mm}$ (group 2) to $1.77 \mathrm{~mm}$ (group 1) more than Procyon mesopic-high.

Considering the other mean differences and 95\% CI's (Tables 1.1 and 1.2), we may conclude that the Colvard measurements correlated favourably to mesopiclow conditions in the Procyon device. 


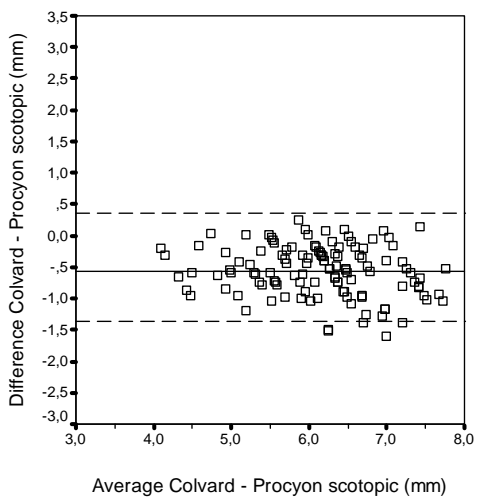

Figure 1.1 Agreement of measurements between the Colvard and the Procyon pupillometer under scotopic illumination in a population of refractive surgery candidates. A solid line represents mean value; an interrupted line represents mean $\pm 2 \mathrm{SD}$

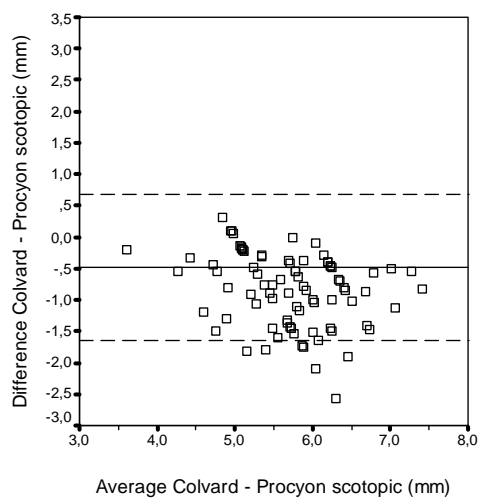

Figure 1.3 Agreement of measurements between the Colvard and the Procyon pupillometer under scotopic illumination in a population after Artisan PIOL implantation. A solid line represents mean value; an interrupted line represents mean $\pm 2 \mathrm{SD}$

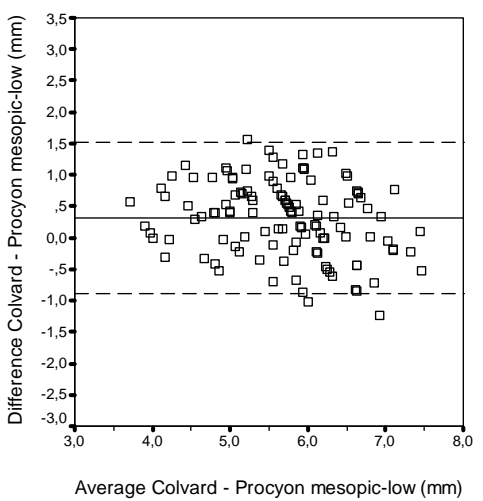

Figure 1.2 Agreement of measurements between the Colvard and the Procyon pupillometer under mesopic-low illumination in a population of refractive surgery candidates. A solid line represents mean value; an interrupted line represents mean $\pm 2 \mathrm{SD}$

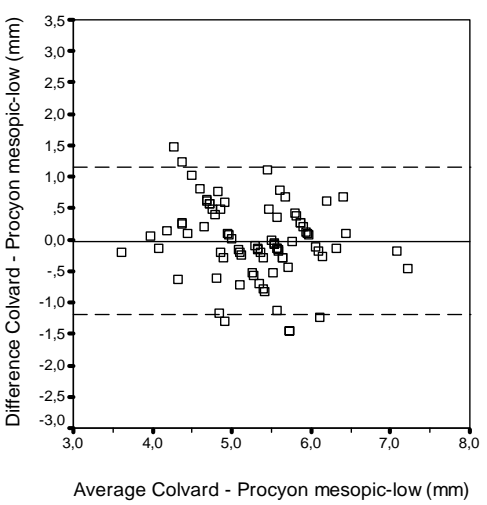

Figure 1.4 Agreement of measurements between the Colvard and the Procyon pupillometer under mesopic-low illumination in a population after Artisan PIOL implantation. A solid line represents mean value; an interrupted line represents mean $\pm 2 \mathrm{SD}$ 


\section{DISCUSSION}

Recently, the measurement of the scotopic pupil size and its relation with NVCs after refractive surgery has become a very important topic in corneal and lenticular refractive surgery (Fan-Paul et al. 2002). Although it is generally believed that a large scotopic pupil size may put patients at an increased risk for NVCs after refractive surgery (Holladay et al. 1991; Martinez et al. 1998; O'Brart et al. 1995; Roberts \& Koester 1993), more recent research argues the importance of the scotopic pupil size (Bailey et al. 2003; Klyce 2004; Pop \& Payette 2004; Probst 2004; Schallhorn et al. 2003).

In addition, in a recent patient satisfaction study after LASIK for correction of myopia, no significant correlation was found between pupil size or pupil-optical zone disparity and NVCs or glare scores (Tahzib et al. 2005). In another patient satisfaction study after implantation of Artisan PIOL for correction of myopia, risk factors such as scotopic and mesopic-low pupil size, pupil-optical zone disparity and decentration of the PIOL were investigated and related to satisfaction scores of glare, night vision and night driving. Correlation was found between glare scores and these risk factors. In contrast, no correlation was found between pupil size and night vision or night driving scores (Tahzib et al. 2006). However, most authors agree that a standardized measurement of pupil size under defined light conditions with good repeatability is of utmost importance for screening patients eligible for refractive surgery (Kohnen et al. 2003; Rosen et al. 2002). It has been shown that the digital Procyon pupillometer has a low variation in measuring pupil size and has good interrater repeatability (Kohnen et al. 2003; Spadea et al. 2005).

The variation in scotopic pupil size measured with different devices emphasizes the need for an objective measurement method. In addition, well-defined illumination conditions enhance comparison of future studies on pupillometry. Therefore, we compared the measurements between the more subjective handheld Colvard pupillometer and the digital Procyon device under defined illuminance levels. The mean differences in the pupil diameters measured by the Colvard and the Procyon devices for the scotopic and mesopic-low illuminance levels were comparable as has been described before (Kohnen et al. 2003; Schmitz et al. 2003). Measurements with the Procyon device under mesopic-low conditions compared most favourably to measurements of the Colvard device in a group of refractive surgery screening candidates as well as in a group of patients after Artisan PIOL implantation. On average, the Colvard measurement was 0.31 $\mathrm{mm}$ larger than the Procyon mesopic-low measurement in the refractive surgery screening group, while in the Artisan PIOL group the Procyon mesopic-low measurement was $0.02 \mathrm{~mm}$ larger than the Colvard measurement.

Despite the fact that pupil size measurements with the Colvard pupillometer have been classified as scotopic pupil size measurements, the results show more correlation with the Procyon measurements under mesopic-low light conditions 
as compared to the Procyon measurements under scotopic conditions. This states the fact that ambient light conditions are of utmost importance in measuring a scotopic pupil size for refractive surgery when using the Colvard pupillometer. The measurements with the Colvard pupillometer are monocular and subject to fluctuations in room illumination. In addition, the relevance of the binocular measured pupil size under well-defined illumination levels has to be related to illumination levels for specific activities in real life, e.g. during driving at night. Binocular measurements may imitate the patient's life conditions more realistically (Kurz et al. 2004). Therefore, we believe that digital binocular infrared pupillometry is advantageous for standardized measurement of the pupil size since it approximates real life conditions more closely. Hence, these standardized measurements may facilitate a more robust evaluation of the relationship between night vision complaints and pupil size under various light conditions. Better predictability of possible visual disturbances may be established and thereby diminish the incidence of glare or possible night vision disturbances after refractive surgery. 


\section{REFERENCES}

1. Bailey MD, Mitchell GL, Dhaliwal DK, Boxer Wachler BS, Zadnik K (2003): Patient satisfaction and visual symptoms after laser in situ keratomileusis. Ophthalmology;110:1371-1378.

2. Bland JM, Altman DG (1986): Statistical methods for assessing agreement between two methods of clinical measurement. Lancet;1:307-310.

3. Bland JM, Altman DG (2003): Applying the right statistics: analyses of measurement studies. Ultrasound Obstet Gynecol;22:85-93.

4. Boxer Wachler BS, Krueger RR (2000): Agreement and repeatability of pupillometry using videokeratography and infrared devices. J Cataract Refract Surg;26:35-40.

5. Colvard M (1998): Preoperative measurement of scotopic pupil dilation using an office pupillometer. J Cataract Refract Surg;24:1594-1597.

6. Fan-Paul NI, Li J, Miller JS, Florakis GJ (2002): Night vision disturbances after corneal refractive surgery. Surv Ophthalmol;47:533-546.

7. Holladay JT, Lynn MJ, Waring GO, 3rd, Gemmill M, Keehn GC, Fielding B (1991): The relationship of visual acuity, refractive error, and pupil size after radial keratotomy. Arch Ophthalmol;109:70-76.

8. Klyce SD (2004): Night vision after LASIK: the pupil proclaims innocence. Ophthalmology;111:1-2.

9. Kohnen T, Terzi E, Buhren J, Kohnen EM (2003): Comparison of a digital and a handheld infrared pupillometer for determining scotopic pupil diameter. J Cataract Refract Surg;29:112-117.

10. Kurz S, Krummenauer F, Pfeiffer N, Dick HB (2004): Monocular versus binocular pupillometry. J Cataract Refract Surg;30:2551-2556.

11. Martinez CE, Applegate RA, Klyce SD, McDonald MB, Medina JP, Howland HC (1998): Effect of pupillary dilation on corneal optical aberrations after photorefractive keratectomy. Arch Ophthalmol;116:1053-1062.

12. O'Brart DP, Corbett MC, Lohmann CP, Kerr Muir MG, Marshall J (1995): The effects of ablation diameter on the outcome of excimer laser photorefractive keratectomy. A prospective, randomized, double-blind study. Arch Ophthalmol;113:438-443.

13. Obstfeld H. Optics in vision, 2nd ed. London: Butterworths, 1982:318-321.

14. Pop M, Payette Y (2004): Risk factors for night vision complaints after LASIK for myopia. Ophthalmology;111:3-10.

15. Pop M, Payette Y, Santoriello E (2002): Comparison of the pupil card and pupillometer in measuring pupil size. J Cataract Refract Surg;28:283-288.

16. Probst LE (2004): The problem with pupils. J Cataract Refract Surg;30:2-4.

17. Roberts CW, Koester CJ (1993): Optical zone diameters for photorefractive corneal surgery. Invest Ophthalmol Vis Sci;34:2275-2281.

18. Rosen ES, Gore CL, Taylor D, Chitkara D, Howes F, Kowalewski E (2002): Use of a digital infrared pupillometer to assess patient suitability for refractive surgery. J Cataract Refract Surg;28:1433-1438. 
19. Schallhorn SC, Kaupp SE, Tanzer DJ, Tidwell J, Laurent J, Bourque LB (2003): Pupil size and quality of vision after LASIK. Ophthalmology;110:1606-1614.

20. Schmitz S, Krummenauer F, Henn S, Dick HB (2003): Comparison of three different technologies for pupil diameter measurement. Graefes Arch Clin Exp Ophthalmol;241:472-477.

21. Schnitzler EM, Baumeister M, Kohnen T (2000): Scotopic measurement of normal pupils: Colvard versus Video Vision Analyzer infrared pupillometer. J Cataract Refract Surg;26:859-866.

22. Spadea L, Giammaria D, Ferrante R, Balestrazzi E (2005): Pre-excimer laser and post-excimer laser refractive surgery measurements of scotopic pupil diameter using 2 pupillometers. Ophthalmology;112:1003-1008.

23. Tahzib NG, Bootsma SJ, Eggink FAGJ, Nuijts RMMA (2006): Functional outcome and patient satisfaction after Artisan phakic intraocular lens implantation for correction of myopia. American Journal of Ophthalmology (In Press).

24. Tahzib NG, Bootsma SJ, Eggink FA, Nabar VA, Nuijts RM (2005): Functional outcomes and patient satisfaction after laser in situ keratomileusis for correction of myopia. J Cataract Refract Surg;31:1943-1951. 
Chapter 2 


\section{Evaluation of pupil dynamics after implantation of Artisan phakic intraocular lenses}

Bootsma SJ, Tahzib NG, Eggink FAGJ, Nuijts RMMA.

J Refract Surg. 2006 Apr;22(4):367-71. 


\section{ABSTRACT}

Purpose: To compare preoperative and postoperative horizontal and vertical pupil diameters after horizontal Artisan phakic intraocular lens (PIOL) implantation for correction of myopia.

Materials and Methods: The preoperative and postoperative scotopic pupil diameters measured by the Colvard pupillometer were compared in 71 eyes after Artisan PIOL implantation (Artisan Colvard group). Analysis of pupil shape (vertical vs. horizontal diameter, V/H ratio) after horizontal Artisan PIOL implantation was performed with the Procyon pupillometer in 121 eyes (Artisan Procyon group) under scotopic, mesopic-low and mesopic-high conditions and compared to an age and refraction matched control group of 121 eyes of refractive surgery candidates (Procyon control group).

Results: After horizontal Artisan PIOL implantation, the mean horizontal pupil diameter decreased from $6.23 \pm .70 \mathrm{~mm}$ preoperatively to $5.34 \pm .68 \mathrm{~mm}$ after surgery in the Artisan Colvard group $(P<.01)$. The mean horizontal scotopic diameter was $5.60 \pm .66$ $\mathrm{mm}$, the mesopic-low diameter was $4.94 \pm .71 \mathrm{~mm}$ and the mesopic-high diameter was $3.98 \pm .54 \mathrm{~mm}$ for the Artisan Procyon group. The mean horizontal scotopic diameter was $6.29 \pm .91 \mathrm{~mm}$, the mesopic-low diameter was $5.40 \pm .96 \mathrm{~mm}$, and the mesopic-high diameter was $4.16 \pm .80$ in the Procyon control group. There was a significant increase in $\mathrm{V} / \mathrm{H}$ ratio under scotopic, mesopic-low and mesopic-high conditions from 1.02, 1.02 and 1.01 in the Procyon control group to 1.17, 1.12 and 1.06 in the Artisan Procyon group $(P<.01)$.

Conclusions: Horizontal pupil size was significantly decreased after horizontal Artisan PIOL implantation and might be attributed to a mechanical restriction of the iris in the horizontal meridian. 


\section{INTRODUCTION}

Pupil size as an influential factor for the development of night vision complaints (NVCs) including halos, starbursts and glare after corneal refractive surgery has been under great discussion lately. ${ }^{1}$ Although many authors suggest that a disparity between the pupil size measured under dim light conditions and the optical zone size of the laser ablation or the phakic intraocular lens (PIOL) ${ }^{2}$ may be responsible for subjective NVCs, recent reports argue the role of the pupil size in the pathophysiology of NVCs. ${ }^{3-7}$ Implantation of Artisan myopia PIOLs has been proven a successful method for correction of moderate to high myopia over the recent years. ${ }^{8-13}$ Changes in pupil size like pupil ovalization after anterior chamber angle supported lens implantation have not been described after implantation of the Artisan iris-fixated PIOL. ${ }^{2,}{ }^{14}$ Recently, a change in pupil size has been described after iris-fixated toric PIOL. ${ }^{15}$ However, the effect of the Artisan iris-fixated PIOL on the pupil dynamics has not been evaluated.

Methods for measuring pupil size over the years have included the use of pupil charts, photo cameras, and more recently, digital and handheld infrared pupillometers. ${ }^{16-20}$ To study potential correlations between pupil size and NVCs the measurement of the pupil size should reflect real-time situations and should be performed under standardized illumination conditions. The two most popular instruments for measuring pupil size under dim light conditions are currently the Colvard pupillometer and the Procyon pupillometer. ${ }^{17,}$ 19, 20 The measurements with the Colvard pupillometer are monocular and subject to fluctuations in room illumination, while with the Procyon pupillometer the measurements are binocular and the levels of illumination are prefixed and standardized. Therefore, Procyon pupillometer measurements may reflect patient's real life conditions, e.g. driving at night, more realistically. ${ }^{21}$

The purpose of this study was to evaluate the effect of horizontal implantation of the Artisan PIOL on the size and shape of the pupil.

\section{MATERIALS AND METHODS}

The Artisan PIOL was designed by Professor J. Worst and was formerly known as the Worst-Fechner claw lens. ${ }^{22}$ The lens has a convex-concave optic with either a $6-\mathrm{mm}$ (for intraocular lens powers up to -15.5 diopters (D)) or a $5-\mathrm{mm}$ (for intraocular lens powers from $-16.0 \mathrm{D}$ up to $-24.0 \mathrm{D}$ ) and is available in 0.50 D steps (Ophtec B.V., Groningen, the Netherlands). This single-piece lens is composed of polymethyl methacrylate. The PIOL is iris claw-fixated. Patients were enrolled at the Academic Centre for Refractive Surgery, University Hospital Maastricht, the Netherlands and were operated for myopia by the same surgeon (RN). The Artisan PIOL was enclavated at the $0-180^{\circ}$ meridian in all patients. 
In the first part of the study, maximal horizontal pupil diameters were measured in 71 eyes of 37 patients (Artisan Colvard group) before and after the horizontal Artisan PIOL implantation, using the handheld Colvard (Oasis Medical, Glendora, CA) pupillometer.

The second part of the study, consisted of the pupil size measurements with the Procyon (P2000 SA pupillometer, Procyon Instruments Ltd.) pupillometer in two populations: a population of 121 eyes of 62 patients (Artisan Procyon group) after horizontal Artisan PIOL implantation and a population of 121 eyes selected out of refractive surgery candidates (Procyon control group) which was matched for age and refraction. The Artisan Procyon and the Procyon control group were compared to evaluate differences in the horizontal and vertical pupil diameters. Postoperative pupil diameters were obtained 3 months after surgery. Exclusion criteria included iris abnormalities and systemic diseases that might affect pupil function. Gonioscopy was used to exclude patients with a plateau iris or a convex iris configuration.

\section{Pupil size measurements}

The handheld Colvard pupillometer uses light amplification technology. The patient is asked to fixate on a red light, produced by an IR-LED inside the device while the examiner is able to focus the iris and pupil by moving the pupillometer slightly forward and back. A millimeter ruler is superimposed by a reticule in the device over the image and allows direct measurement. The examiner was instructed to estimate the horizontal pupil diameter size with a precision of 0.25 $\mathrm{mm}$, while covering the contralateral eye with the other hand.

The Procyon pupillometer is a digital infrared device for binocular simultaneous measurements of pupil diameter at 3 levels of luminance (scotopic [0.04 lux], mesopic-low [0.4 lux], and mesopic-high [4.0 lux]). Infrared light-emitting diodes illuminate the eyes with long-wave light that does not affect pupil size but is recognized by the charge-coupled device camera in the system. For both eyes, 10 images were acquired at each level of luminance, and stored into a computer. The patient looks into the device and fixates on a black spot at a virtual distance of $10 \mathrm{~m}$. Rubber eyecups prevent the illumination level to rise above the adjusted level. The examiner could view the acquired images immediately and distorted images were removed. The mean and standard deviation (SD), and range of scotopic, mesopic-low, and mesopic-high pupil diameters were assessed by the software and displayed as a diagram.

Before each measurement, a one-minute dark adaptation was taken into account. Surrounding room illumination was measured no more than 0.15 lux. Definitions on scotopic and mesopic levels of illumination were used according to the International Commission on Illumination as scotopic being less than 0.05 lux and mesopic between 0.05 and 50 lux (National Physical Laboratory, London, 


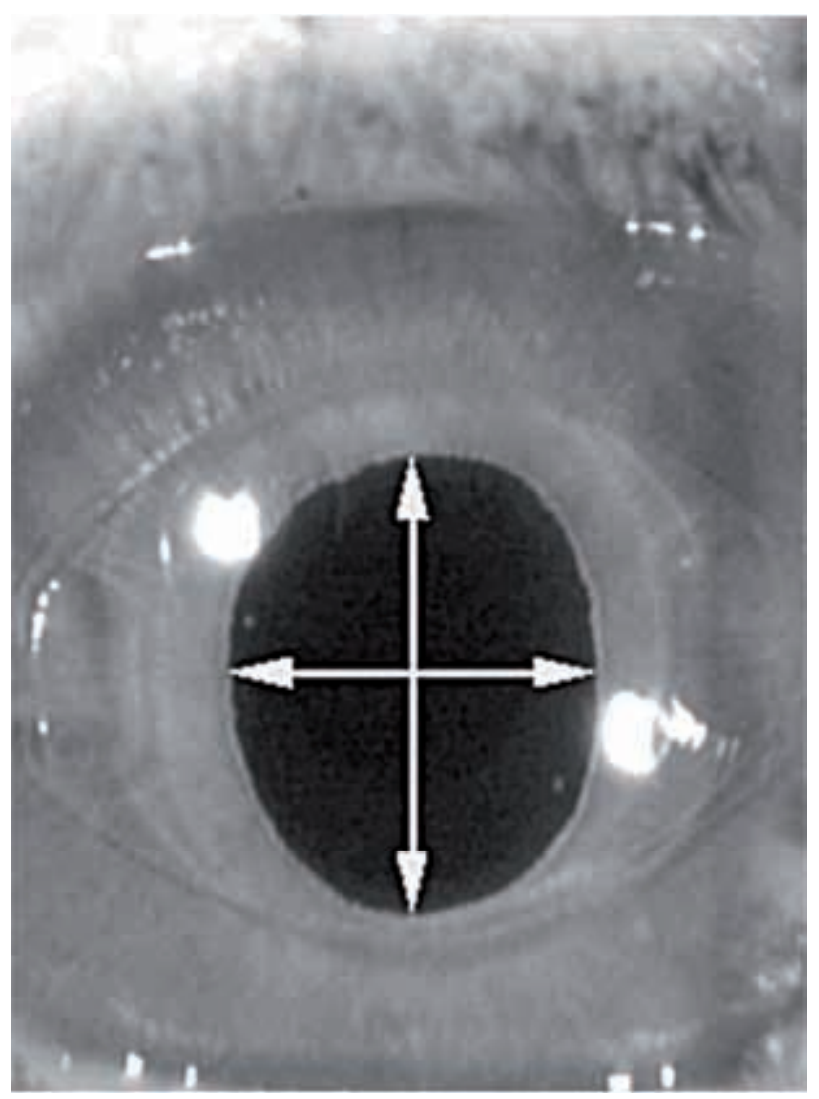

Figure 1. Ovalization of the pupil after Artisan Phakic IntraOcular Lens implantation under mesopic-low light conditions using Procyon pupillometry.

United Kingdom). ${ }^{23}$ All Colvard and Procyon measurements were taken by one experienced examiner.

Digital images from the Procyon measurements were converted to Adobe Photoshop 5.0 software program (1989-1998 Adobe systems Inc.). Horizontal and vertical diameters were obtained using the measurement tool inside the program (Figure 1). The ratio between the vertical and horizontal pupil diameters, the so-called V/H ratio, was calculated from measurements with the Procyon device under all three light conditions. A ratio of 1.00 represents a perfect circular pupil shape.

In measuring the pupil size via the cornea and the anterior chamber one should realize that not the natural pupil is seen, but its image which is called the entrance pupil. Since in this study we are interested in comparing measured pupil sizes, it is appropriate to use the size of the entrance pupil. However, postoperatively the size of the entrance pupil is also changed by the Artisan PIOL since the PIOL 
is positioned in front of the pupil entrance. Optically, the natural pupil is first imaged by the Artisan PIOL and secondly by the cornea / anterior chamber system. The distance from pupil to lens is given by the back surface sagittal depth called the vault by the manufacturer $(0.799 \mathrm{~mm}$ for powers up to -15.5 $\mathrm{D}$ and $0.733 \mathrm{D}$ for powers $<-15.5 \mathrm{D})$. Since the Artisan PIOL is placed in the anterior chamber fluid (refractive index $=1.336$ ) and is very close to the pupil, the object vergence is very high compared to the effective power of the Artisan PIOL, resulting in a smaller than $1 \%$ change in pupil size. Nevertheless, we have adjusted our measured pupil size data for the influence of the Artisan PIOL using the following formula ${ }^{24}$ :

Corrected Entrance Pupil $=\left(1-\frac{\text { vault of Artisan PIOL in mm } \times \text { Dioptric power of Artisan PIOL }}{1336}\right) \times$ Measured pupilsize inmm

Statistical analysis

All data were expressed as mean \pm SD. Measured pupil diameters were distributed normally (Kolmogorov-Smirnov test). Independent and paired-samples t-tests were used for analysis. P-values less than 0.05 were considered statistically significant (SPSS for Windows, SPSS Inc., Chicago, IL).

\section{RESULTS}

The mean \pm SD horizontal pupil diameter measured with the Colvard pupillometer (Artisan Colvard group) after horizontal Artisan PIOL implantation decreased from $6.23 \pm .70 \mathrm{~mm}$ preoperatively to $5.34 \pm .68 \mathrm{~mm}$ after surgery $(\mathrm{P}$ $<$.01) (Table 1). This is a mean reduction of $13.8 \pm 10.6 \%$ in horizontal pupil diameter after implantation.

Horizontal pupil diameters measured with the Procyon device after horizontal Artisan PIOL implantation (Artsian Procyon group) were $5.60 \pm .66 \mathrm{~mm}$ (scotopic), $4.94 \pm .71 \mathrm{~mm}$ (mesopic-low) and $3.98 \pm .54 \mathrm{~mm}$ (mesopic-high). In the Procyon control group, the mean \pm SD horizontal pupil diameter measured with the Procyon pupillometer was $6.29 \pm .91 \mathrm{~mm}$ (scotopic), $5.40 \pm .96 \mathrm{~mm}$ (mesopic-low) and $4.16 \pm .80 \mathrm{~mm}$ (mesopic-high) (Table 1 and Table 2).

There was a decrease in the horizontal pupil diameter after horizontal Artisan PIOL implantation under all three light conditions $(\mathrm{P}<.01)$. In contrast, no change occurred in the vertical axis (Table 2). In the Procyon control group, the mean $\mathrm{V} / \mathrm{H}$ ratio for scotopic, mesopic-low and mesopic-high light conditions was 1.02, 1.02 and 1.01. After horizontal Artisan PIOL implantation (Artisan Procyon group) the mean V/H-ratio significantly increased to $1.17,1.12$ and 1.06 (Table 2, Figure 2). 
Table 1. Horizontal pupil diameter in millimeter for all three groups. A V/H-ratio ${ }^{\star}$ has been given for the Artisan Procyon and the Procyon control groups. The Procyon diameters represent scotopic conditions

\begin{tabular}{|c|c|c|c|}
\hline & & Horizontal diameter $\left[\mathrm{SD}^{\dagger}\right]$ & V/H-ratio \\
\hline \multirow[t]{2}{*}{ Artisan Colvard group } & before implantation & $6.23[0.70]$ & \\
\hline & after implantation & $5.34[0.68]$ & \\
\hline Artisan Procyon group & after implantation & $5.60[0.66]$ & 1.17 \\
\hline Procyon control group & & $6.29[0.91]$ & 1.02 \\
\hline
\end{tabular}

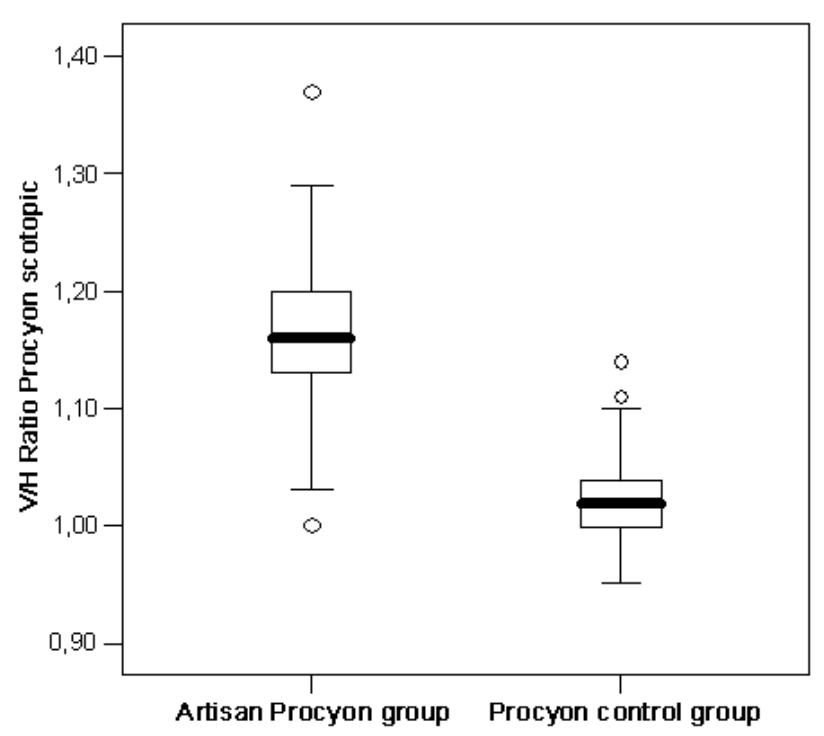

Figure 2. Box-plot showing the range of Vertical/Horizontalratios measured in the post-Artisan Phakic Intraocular Lens implantation group (Artisan Procyon group) and the refractive surgery screening group (Procyon control group) under scotopic condition ( $\mathrm{n}=121$ for both groups). The difference between the groups is significant $(P<.01)$. 


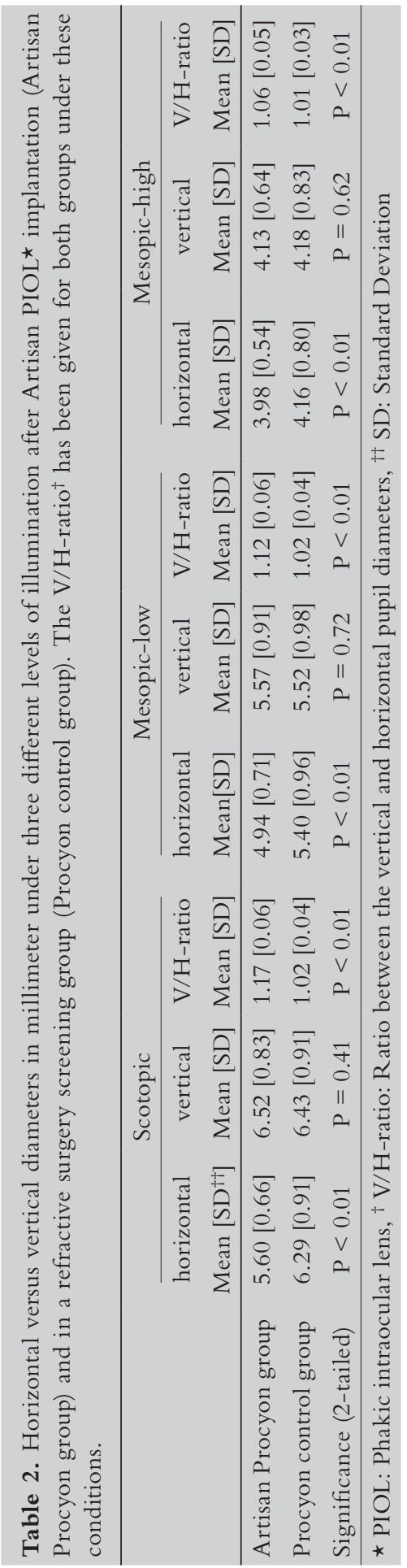




\section{DISCUSSION}

Recently, the measurement of the scotopic pupil size and its relation with NVCs after refractive surgery has become a very important topic in corneal and lenticular refractive surgery. ${ }^{1}$ Although it is generally believed that a large scotopic pupil size may put patients at an increased risk for NVCs after refractive surgery ${ }^{25-28}$, more recent research argues the importance of the scotopic pupil size. ${ }^{3-7}$ However, most authors agree that a standardized measurement of pupil size under defined light conditions with good repeatability is of utmost importance for screening patients eligible for refractive surgery. ${ }^{20,23}$ In addition, the relevance of the binocular measured pupil size under well-defined illumination levels has to be related to illumination levels for specific activities in real life, e.g. during driving at night. Binocular measurements may imitate the patient's life conditions more realistically. ${ }^{21}$ It has been shown that the digital Procyon pupillometer has a low variation in measuring pupil size and has good interrater repeatability. ${ }^{20}$ The variation in scotopic pupil size measured with different devices emphasizes the need for an objective measurement method. In addition, well-defined illumination conditions enhance comparison of future studies on pupillometry.

After implantation of PIOLs, especially with anterior chamber angle-fixated lenses, progressive changes like pupil ovalization and atrophy of iris stroma due to infarction of iris vessels in the chamber angle have been reported. ${ }^{2,}{ }^{14,29}$ It has been suggested that the Artisan PIOL has no influence on pupil dynamics because of the enclavation of the haptics in the mid-periphery of the iris, far away from the vulnerable chamber angle structures. ${ }^{30}$ Consequently, the implantation of iris-fixated PIOLs has become increasingly popular and has been proven successful for the correction of moderate to high refractive errors. For Artisan PIOLs with a 6-mm optical zone, the manufacturer prefers that the Artisan PIOL lenses not be implanted in eyes with a scotopic pupil size over $6 \mathrm{~mm}$. This is stated because of the presumed correlation between NVCs including contrast sensitivity loss, glare, and halos and a disparity of the optical lens zone with the pupil diameter. However, we do not know the methods and illumination levels that have been used by the manufacturer to formulate this advice. To evaluate the effect of the iris fixation mechanism of the Artisan lens on pupil dynamics, we measured the horizontal scotopic pupil size with the Colvard device before and after horizontal Artisan PIOL implantation. In addition, we calculated the ratio between the vertical and horizontal pupil diameter after horizontal Artisan lens implantation ( $\mathrm{V} / \mathrm{H}$ ratio). After horizontal Artisan lens implantation, the horizontal pupil diameter decreased on average by $13.8 \%$. The relation between individual vertical and horizontal pupil diameters in normal subjects was recently investigated and provided comparable results to our findings, e.g. a ratio of 1.01 to $1.03 .{ }^{31}$ Dick et al. ${ }^{15}$ described a change in pupil size after implantation of toric PIOLs using pharmacological mydriasis and flash slit lamp photography. 
Our study demonstrates a restriction in the dilation of pupils in the horizontal axis after horizontal Artisan myopia PIOL implantation under physiological light conditions. A possible explanation for this restriction could be the mechanically induced prevention of pupil dilatation by the iris claw. It seems unlikely that the function of the dilator pupillae muscle is impaired by the induction of ischemia by the enclavation of the iris claw itself, since this has not been supported by fluorescein angiography studies in the past. ${ }^{30}$

The main finding of this study was the detection of a decreased horizontal meridian of the pupil after horizontal Artisan PIOL implantation, as compared to the vertical meridian, at all 3 levels of illuminance, i.e. scotopic, mesopic-low and mesopic-high. The postoperative constriction in the horizontal axis and subsequent smaller scotopic pupil diameter may have implications for the inclusion criteria for implantation, since a relatively larger proportion of patients would fit the currently formulated inclusion criteria where the optical zones should be at least as large as the scotopic pupil size.

In summary, horizontal pupil size is diminished after horizontal Artisan PIOL implantation and a significant change in $\mathrm{V} / \mathrm{H}$ ratio was measured under three levels of illumination leading to a vertical ovalization of the pupil. The decrease in the postoperative pupil area could be beneficial for reduction of aberrations and thereby diminish the incidence of night vision disturbances. A digital infrared pupillometer not only is advantageous for standardized measurement of the horizontal pupil diameter, but also may give insight into the mechanical effects of PIOLs on pupillary dynamics. 


\section{REFERENCES}

1. Fan-Paul NI, Li J, Miller JS, Florakis GJ. Night vision disturbances after corneal refractive surgery. Surv Ophthalmol. 2002;47:533-546.

2. Alio JL, de la Hoz F, Perez-Santonja JJ, Ruiz-Moreno JM, Quesada JA. Phakic anterior chamber lenses for the correction of myopia: a 7-year cumulative analysis of complications in 263 cases. Ophthalmology. 1999;106:458-466.

3. Pop M, Payette Y. Risk factors for night vision complaints after LASIK for myopia. Ophthalmology. 2004;111:3-10.

4. Klyce SD. Night vision after LASIK: the pupil proclaims innocence. Ophthalmology. 2004;111:1-2.

5. Bailey MD, Mitchell GL, Dhaliwal DK, Boxer Wachler BS, Zadnik K. Patient satisfaction and visual symptoms after laser in situ keratomileusis. Ophthalmology. 2003;110:1371-1378.

6. Probst LE. The problem with pupils. J Cataract Refract Surg. 2004;30:2-4.

7. Schallhorn SC, Kaupp SE, Tanzer DJ, Tidwell J, Laurent J, Bourque LB. Pupil size and quality of vision after LASIK. Ophthalmology. 2003;110:1606-1614.

8. Maloney RK, Nguyen LH, John ME. Artisan phakic intraocular lens for myopia:shortterm results of a prospective, multicenter study. Ophthalmology. 2002;109:1631-1641.

9. Budo C, Hessloehl JC, Izak M, et al. Multicenter study of the Artisan phakic intraocular lens. J Cataract Refract Surg. 2000;26:1163-1171.

10. Hardten DR. Phakic iris claw artisan intraocular lens for correction of high myopia and hyperopia. Int Ophthalmol Clin. 2000;40:209-221.

11. Landesz M, van Rij G, Luyten G. Iris-claw phakic intraocular lens for high myopia. J Refract Surg. 2001;17:634-640.

12. El Danasoury MA, El Maghraby A, Gamali TO. Comparison of iris-fixed Artisan lens implantation with excimer laser in situ keratomileusis in correcting myopia between -9.00 and -19.50 diopters: a randomized study. Ophthalmology. 2002;109:955-964.

13. Malecaze FJ, Hulin H, Bierer P, et al. A randomized paired eye comparison of two techniques for treating moderately high myopia: LASIK and artisan phakic lens. Ophthalmology. 2002;109:1622-1630.

14. Allemann N, Chamon W, Tanaka HM, et al. Myopic angle-supported intraocular lenses: two-year follow-up. Ophthalmology. 2000;107:1549-1554.

15. Dick HB, Aliyeva S, Tehrani M. Change in pupil size after implantation of an irisfixated toric phakic intraocular lens. J Cataract Refract Surg. 2005;31:302-307.

16. Boxer Wachler BS, Krueger RR. Agreement and repeatability of pupillometry using videokeratography and infrared devices. J Cataract Refract Surg. 2000;26:35-40.

17. Colvard M. Preoperative measurement of scotopic pupil dilation using an office pupillometer. J Cataract Refract Surg. 1998;24:1594-1597.

18. Pop M, Payette Y, Santoriello E. Comparison of the pupil card and pupillometer in measuring pupil size. J Cataract Refract Surg. 2002;28:283-288. 
19. Schnitzler EM, Baumeister M, Kohnen T. Scotopic measurement of normal pupils: Colvard versus Video Vision Analyzer infrared pupillometer. J Cataract Refract Surg. 2000;26:859-866.

20. Kohnen T, Terzi E, Buhren J, Kohnen EM. Comparison of a digital and a handheld infrared pupillometer for determining scotopic pupil diameter. J Cataract Refract Surg. 2003;29:112-117.

21. Kurz S, Krummenauer F, Pfeiffer N, Dick HB. Monocular versus binocular pupillometry. J Cataract Refract Surg. 2004;30:2551-2556.

22. Worst JG, van der Veen G, Los LI. Refractive surgery for high myopia. The WorstFechner biconcave iris claw lens. Doc Ophthalmol. 1990;75:335-341.

23. Rosen ES, Gore CL, Taylor D, Chitkara D, Howes F, Kowalewski E. Use of a digital infrared pupillometer to assess patient suitability for refractive surgery. J Cataract Refract Surg. 2002;28:1433-1438.

24. Obstfeld H. Optics in vision, 2nd ed. London: Butterworths, 1982:318-321.

25. Holladay JT, Lynn MJ, Waring GO, 3rd, Gemmill M, Keehn GC, Fielding B. The relationship of visual acuity, refractive error, and pupil size after radial keratotomy. Arch Ophthalmol. 1991;109:70-76.

26. Roberts CW, Koester CJ. Optical zone diameters for photorefractive corneal surgery. Invest Ophthalmol Vis Sci. 1993;34:2275-2281.

27. O'Brart DP, Corbett MC, Lohmann CP, Kerr Muir MG, Marshall J. The effects of ablation diameter on the outcome of excimer laser photorefractive keratectomy. A prospective, randomized, double-blind study. Arch Ophthalmol. 1995;113:438-443.

28. Martinez CE, Applegate RA, Klyce SD, McDonald MB, Medina JP, Howland HC. Effect of pupillary dilation on corneal optical aberrations after photorefractive keratectomy. Arch Ophthalmol. 1998;116:1053-1062.

29. Perez-Santonja JJ, Alio JL, Jimenez-Alfaro I, Zato MA. Surgical correction of severe myopia with an angle-supported phakic intraocular lens. J Cataract Refract Surg. 2000;26:1288-1302.

30. Menezo JL, Avino JA, Cisneros A, Rodriguez-Salvador V, Martinez-Costa R. Iris claw phakic intraocular lens for high myopia. J Refract Surg. 1997;13:545-555.

31. Khanani AM, Archer SM, Brown SM. Horizontal versus vertical dark-adapted pupil diameters in normal individuals. J Cataract Refract Surg. 2004;30:2557-2558. 


\section{Functional outcome and patient satisfaction after laser in situ keratomileusis for correction of myopia}

Tahzib NG, Bootsma SJ, Eggink FA, Nabar VA, Nuijts RM.

J Cataract Refract Surg. 2005;31:1943-1951. 


\section{ABSTRACT}

Purpose: To determine subjective patient satisfaction and self-perceived quality of vision after laser in situ keratomileusis (LASIK) to correct myopia and myopic astigmatism.

Setting: Department of Ophthalmology, Academic Hospital Maastricht, the Netherlands.

Methods: A validated questionnaire consisting of 66 items was self-administered by 142 consecutive patients. Seven scales covering a specific aspect of quality of vision were formulated including global satisfaction, quality of uncorrected and corrected vision, quality of night vision, glare, daytime driving and night driving. Main outcome measures were responses to individual questions and scale scores and correlations with clinical parameters including refractive outcome, uncorrected visual acuity (UCVA) and best-corrected visual acuity (BCVA), ablation depth, and scotopic pupil-optical zone disparity were obtained.

Results: The mean score for the overall satisfaction was $4.1 \pm 0.71$ (scale 0 to 5.0 ). $92.2 \%$ of patients were satisfied or very satisfied with their surgery, $93.6 \%$ considered their main goal of surgery achieved and $92.3 \%$ would choose to undergo LASIK surgery again. Satisfaction with uncorrected vision was $3.03 \pm 0.71$. The mean score for glare was 3.0 \pm 0.9 . At night, glare from lights was believed to be more important than before surgery by $47.2 \%$. Glare from oncoming car headlights after surgery was reported by $58.4 \%$, and was believed to be more bothersome for night driving than before surgery by $52.8 \%$. Night driving was rated more difficult by $39.4 \%$ than before surgery, while $59.3 \%$ had less difficulty driving at night. There was a significant correlation between uncorrected vision score and postoperative spherical equivalent $(\mathrm{SE})(\mathrm{r}=.245)$ and postoperative astigmatism $(\mathrm{r}=.265)$, respectively. There was no correlation between the glare or night vision scores and the degree of correction, the amount of ablation depth or the disparity between the scotopic pupil and the optical zone.

Conclusion: Self-perceived uncorrected vision after LASIK surgery for the correction of myopia and myopic astigmatism appears to be very good and is related to the postoperative residual error. Although the majority of patients postoperatively experienced glare, particularly with driving at night, this was not related to the pupil-optical zone disparity or degree of correction. 


\section{INTRODUCTION}

Studies of the medical outcome of laser refractive surgery for the treatment of ametropia, including myopia and astigmatism have shown great success. ${ }^{1,2}$ Likewise, patient satisfaction after laser in situ keratomileusis (LASIK) reportedly ranges from $82 \%$ to $98 \% .^{3-6}$

Despite the high success rate, quality of vision problems after refractive surgery techniques such as photorefractive keratectomy (PRK) and LASIK have been reported in many clinical studies. ${ }^{6-13}$ Glare and halos and subsequent night vision complaints (NVCs) are among the prime complaints reported by patients. These problems may be attributed to a loss of contrast sensitivity or low-contrast visual acuity. $6,14,15$ Reports have linked the relationship between the ablation zone and the dim light pupil size to NVCs early postoperatively after refractive surgery. ${ }^{8}$ Many surgeons in the past have recommended that LASIK should not be performed on patients whose pupil size is larger than the treatment optical zone. $^{16,17}$ For a long time, pupil size has been suspected to be a direct cause of NVCs, a role that has been assigned hypothetically based on optical theory. ${ }^{10}$ Recent studies show that pupil size is indeed a significant predictor of glare and halos after LASIK, especially in the first postoperative month, yet they demonstrate that pupil size is not a significant variable 6 or 12 months after treatment. ${ }^{8}$ It appears that pupil size only partially explains the differences in reports about quality of vision after LASIK. ${ }^{8-13}$

The necessity for a more precise assessment of subjective quality of vision and patient satisfaction after refractive surgery has increased with the discovery of persistent NVCs. The aim of our study was to determine subjective patient satisfaction and self-perceived outcome after LASIK surgery for the correction of myopia and myopic astigmatism. We investigated possible determinants of postoperative visual complaints such as refractive status, the ablation depth, the pupil size and the disparity between pupil size and the optical zone.

\section{METHODS}

The questionnaire used in our study is a psychometric instrument that was developed and validated by Brunette et al. and has been previously used for the evaluation of patient satisfaction after PRK and to assess postoperative visual symptoms. ${ }^{1,2}$ The questionnaire was translated into the Dutch language from the original English. The instrument has proven to be reliable by a high level of internal consistency with Cronbach's alpha coefficients superior or equal to 0.83 . For analysis purposes, the 66 items of the questionnaire were grouped in seven distinct scales which were self-administered by patients. Scale scores increased with satisfaction, ranging from 1 (very dissatisfied) to 5 (very satisfied). Each of the seven scales covered a specific aspect of quality of vision, including global 
satisfaction, quality of uncorrected and corrected vision, quality of night vision, glare, daytime driving and night driving. The entry of all data from the questionnaires was performed by one independent physician (N.T.), not involved in the treatment or follow-up of the patients.

All treatments were performed by a single surgeon (R.N.) at the Academic Center for Refractive Surgery, University Eye Clinic of Maastricht. Patients had either standard LASIK (PlanoScan, Bausch \& Lomb, Munich, Germany) or wavefrontguided LASIK (Zyoptix, Bausch \& Lomb, Munich, Germany). Included patients had at least stable myopia for 2 years and were examined preoperatively and at day 1 , week 1 , month 1 , month 3 , month 6 , and from then at 6 months intervals. Preand postoperatively, subjective and objective refraction, slit-lamp microscopy, applanation tonometry, fundus examination and corneal topography (Orbtek Orbscan II, version 3.10.31, Bausch \& Lomb, Munich, Germany) were assessed. Scotopic (dim light) pupil size was measured with the handheld Colvard pupillometer (Oasis Medical, Glendora, CA) ${ }^{16,18}$ It is said to use light amplification technology, that enables the examiner to focus the iris and pupil by moving the pupillometer slightly forward and back. Patients had a one-minute dark adaptation before measurements and were then asked to fixate on an infrared lightemitting diode, which emits red light at very low levels. A millimeter ruler was superimposed by a reticle in the device. The largest horizontal scotopic pupil diameter was estimated with a precision of $0.1 \mathrm{~mm}$. Illumination conditions were no more than 0.15 lux throughout the examination room. The pupil-optical zone disparity, which is defined as the difference between the scotopic pupil size and the optical zone of the laser treatment, was calculated.

Patients who were treated within the period January 2001 to December 2003 received a questionnaire by regular mail, including a brief accompanying letter indicating the aim of the study. Patients with a minimum of 4 months of followup and a stable postoperative refraction were included in the study. Investigational review board approval was obtained from the Academic Hospital Maastricht, the Netherlands.

For statistical purposes, uncorrected and corrected visual acuity in logMAR of the best eye was used for calculations, which means the lower the value, the better the vision. Correlations between the scale scores and clinical parameters were assessed with the Pearson $r$ coefficient of correlation and the Spearman rank correlation (SPSS for Windows, SPSS Inc., Chicago, IL). The strength of the correlation between two variables was defined as strong $(r \geq .60)$, moderate $(.30 \leq \mathrm{r}<.60)$, or weak $(.10 \leq \mathrm{r}<.30)$. All values in the text are mean \pm standard deviation (SD).

As to the surgical technique, in a first step, a flap with a diameter of $9.5 \mathrm{~mm}$ and a thickness of $160 \mu \mathrm{m}$ was created with a superior hinge with a Hansatome microkeratome (Bausch \& Lomb, Munich, Germany). The ablation was performed

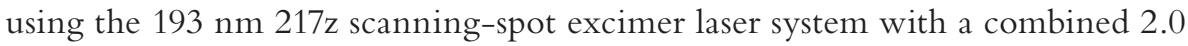
$\mathrm{mm}$ and $1.0 \mathrm{~mm}$ spot in the Zyoptix group. The PlanoScan was treated with 
a $2.0 \mathrm{~mm}$ scanning spot. The PlanoScan and Zyoptix software programs were used for the standard and wavefront-guided treatments, respectively. Before each treatment, the laser was calibrated by a fluence test and the eye-tracking system was tested. The radiant exposure was $0.2 \mathrm{~J} / \mathrm{cm}^{2}$ in the treatment plan and the repetition frequency of the laser was $120 \mathrm{~Hz}$. After the photoablation, the lamella was repositioned and the interface floated with a balanced salt solution. Ofloxacin $0.3 \%$ (Trafloxal $^{\circledR}$, Tramedico, Weesp, the Netherlands) and fluoromethalone $0.1 \%$ (FML Liquifilm ${ }^{\circledR}$, Allergan, Co. Mayo, Ireland) drops were used 4 times daily for 2 days. Sodium hyaluronate $0.18 \%$ drops $\left(V_{\text {Vislube }}{ }^{\circledR}\right.$, TRB Chemedica, Newcastle under Lyme, United Kingdom) were given 4 times daily for 1 week.

\section{RESULTS}

A total of 142 patients were included in our study. Population characteristics are listed in Table 1 . The mean patient age was $43 \pm 10.0$ years (SD) (range 21-67 years). The mean follow-up time for the medical outcome was $11 \pm 4.29$ months (range 4-36 months). Tables 2 to 7 show the scores for all seven quality of vision scales. The mean time interval for the self-administration of the questionnaire was $24.06 \pm 11.01$ months (range $4-36$ months). Of our patients, $48.6 \%$ selfadministered the questionnaire within the first 2 years and $51.4 \%$ within the third year after surgery.

\section{Patient satisfaction and self-perceived outcome}

The most frequently reported motivations for desiring surgical correction were to be less dependent on glasses (12.5\%), intolerance to contact lens wear $(8.3 \%)$ and problems in handling contact lenses (7.2\%).

Global satisfaction. The mean score for the overall satisfaction was $4.10 \pm 0.71$ (5 meaning totally satisfied). The majority of patients (93.6\%) reported that their main goal had been achieved and would be willing to have the surgery done again if they could do it over (92.3\%). Global satisfaction did not show a correlation with patient age.

Quality of daytime vision without correction. The mean score for all patients was $3.03 \pm 0.71$; Uncorrected distance vision was characterized as slightly or much better than preoperative corrected vision by $40 \%$ of patients.

Symptoms reported to be more frequent than before surgery included blurred vision (33.1\%), sensitivity to smoke (27.4\%) and distortion of fine details $(21.8 \%)$, a double outline of images (7.7\%), and ghost images (7.0\%).

Uncorrected near vision was characterized as slightly or much better than the preoperative corrected near vision by $9.3 \%$ of patients.

Quality of daytime vision with correction. The mean score for patients wearing glasses for quality of daytime vision was $2.95 \pm 1.08$. Wearing glasses 
Table 1. Population Characteristics

\begin{tabular}{|c|c|c|c|}
\hline Characteristics & $\begin{array}{l}\text { Mean } \pm \mathrm{SD} \\
\text { or } \% \text { patients }\end{array}$ & Median & Range \\
\hline Age (yrs) & $43.0 \pm 10.0$ & 42.0 & 21.0 to 67.0 \\
\hline Follow-up time medical outcome (mos) & $10.5 \pm 4.29$ & 12.0 & 4.0 to 36.0 \\
\hline \multicolumn{4}{|l|}{ Before surgery $(n=142)$} \\
\hline Mean SE (diopters [D]) & $-4.96 \pm 2.15$ & -5.0 & -9.13 to -0.50 \\
\hline \multicolumn{4}{|l|}{ Simulated keratometry values (D) } \\
\hline Steep meridian & $44.10 \pm 1.73$ & & \\
\hline Flat meridian & $42.78 \pm 1.66$ & & \\
\hline Mean BCVA 20/20 or better & $80 \%$ & & \\
\hline BCVA between $20 / 20$ and 20/40 & $100 \%$ & & \\
\hline BCVA $20 / 40$ or worse & $0 \%$ & & \\
\hline Mean pupil diameter $(\mathrm{mm})$ & $5.9 \pm 0.84$ & 6.0 & 3.1 to 7.50 \\
\hline \multicolumn{4}{|l|}{ At the last follow-up ( $\mathrm{n}=142)$} \\
\hline \multicolumn{4}{|l|}{ Visual acuity in the best eye $(n=142)$} \\
\hline UCVA $20 / 20$ or better & $73 \%$ & & \\
\hline UCVA between $20 / 20$ and $20 / 40$ & $99.3 \%$ & & \\
\hline UCVA $20 / 40$ or worse & $0.7 \%$ & & \\
\hline Loss of 1 line of BCVA & $11.3 \%$ & & \\
\hline Loss of 2 lines of BCVA & $1.4 \%$ & & \\
\hline \multicolumn{4}{|l|}{ Refraction $(n=142)$} \\
\hline Mean SE (D) & $-0.17 \pm 0.36$ & 0.0 & -1.0 to 0.75 \\
\hline Mean SE within $1.00 \mathrm{D}$ of emmetropia & $97 \%$ & & \\
\hline Mean SE within $0.5 \mathrm{D}$ of emmetropia & $86.8 \%$ & & \\
\hline \multicolumn{4}{|l|}{ Simulated keratometry values (D) } \\
\hline Steep meridian & $40.0 \pm 2.05$ & & \\
\hline Flat meridian & $39.1 \pm 2.01$ & & \\
\hline
\end{tabular}

$\mathrm{BCVA}=$ best-corrected visual acuity; $\mathrm{SE}=$ spherical equivalent; $\mathrm{UCVA}=$ uncorrected visual acuity.

Table 2. Global Satisfaction Scale Score

\begin{tabular}{lcc}
\hline Global Satisfaction & Mean $\pm \mathrm{SD} \star$ or $\%$ & Range \\
\hline Mean score & $4.1 \pm 0.7$ & $1.2-5.0$ \\
Main goal achieved & 93.6 & \\
Satisfied with result & 92.2 & \\
Surgery was good choice & 92.3 & \\
Would do the surgery again & 92.3 & \\
Expected quality of vision achieved & 88.0 & \\
Independence of correction considered & 76.1 & \\
best result & 27.2 & \\
Improved quality of life at work & 37.0 & \\
Improved quality of social life & 23.3 & \\
Improved quality of family life &
\end{tabular}

*Scores 0-5 (5 meaning totally satisfied). 
Table 3. Uncorrected Vision Scale Score

\begin{tabular}{lcc}
\hline Uncorrected Vision & Mean \pm SD ${ }^{\star}$ or $\%$ & Range \\
\hline $\begin{array}{l}\text { Mean score } \\
\text { Uncorrected distance vision better than preoperative } \\
\text { corrected vision }\end{array}$ & $4.1 \pm 0.7$ & $1.1-5.0$ \\
$\begin{array}{l}\text { Uncorrected distance vision same as preoperative } \\
\text { corrected vision }\end{array}$ & 29.3 \\
$\begin{array}{l}\text { Uncorrected distance vision worse than preoperative } \\
\text { corrected vision }\end{array}$ & 30.7 \\
$\begin{array}{l}\text { Uncorrected near vision better than preoperative } \\
\text { corrected vision }\end{array}$ & 9.3 \\
$\begin{array}{l}\text { Uncorrected near vision same as preoperative } \\
\text { corrected vision } \\
\begin{array}{l}\text { Uncorrected near vision worse than preoperative } \\
\text { corrected vision }\end{array}\end{array}$ \\
$\begin{array}{l}\text { Newspaper headlines more easily read without } \\
\text { correction after surgery }\end{array}$ & 37.1 \\
$\begin{array}{l}\text { Computer screen more easily read without correc- } \\
\text { tion after surgery }\end{array}$ & 9.3 \\
\hline
\end{tabular}

* Scores 0-5 (5 meaning totally satisfied).

Table 4. Corrected Vision Scale Score

\begin{tabular}{lcc}
\hline Uncorrected Vision & Mean $\pm \mathrm{SD}$ * or \% & Range \\
\hline Mean score & $2.95 \pm 1.08$ & $1.0-5.0$ \\
Wearing glasses for distance vision on a regular basis & 13.4 & \\
Wearing contactlenses for distance vision on a & 1.4 & \\
regular basis & 23.2 & \\
Wearing near vision correction on a regular basis & & \\
* Scores 0-5 (5 meaning totally satisfied). &
\end{tabular}

Table 5. Night Vision Scale Score

\begin{tabular}{lcc}
\hline Uncorrected Vision & Mean $\pm \mathrm{SD}^{\star}$ or $\%$ & Range \\
\hline Mean score & $3.1 \pm 0.7$ & $1.4-4.5$ \\
Night vision considered same or better than before & 66.2 & \\
surgery & \\
Night vision considered worse or much worse than & 33.8 \\
before surgery & $28.1 / 52.8$ \\
Halos (before/after) & $18.3 / 30.2$ \\
Perception of stars around lights (before/after) & $18.3 / 26.0$ \\
Distortion of details (before/after) & $6.3 / 9.1$ \\
Double outline of images (before/after) & $4.2 / 5.6$ & \\
Ghost images (before/after) & & \\
^Scores 0-5 (5 meaning totally satisfied). &
\end{tabular}


Table 6. Glare Scale Score

\begin{tabular}{lcc}
\hline Uncorrected Vision & Mean $\pm \mathrm{SD}$ or $\%$ & Range \\
\hline $\begin{array}{l}\text { Mean score } \\
\text { Glare from lights at night increased compared to before }\end{array}$ & $3.0 \pm 0.9$ & $1.1-4.9$ \\
surgery & 47.2 & \\
$\begin{array}{l}\text { Glare from oncoming headlights considered bothersome } \\
\text { before surgery }\end{array}$ & 40.9 \\
$\begin{array}{l}\text { Glare from oncoming headlights considered bothersome } \\
\text { after surgery }\end{array}$ & 58.4 \\
$\begin{array}{l}\text { Glare after surgery considered more bothersome than } \\
\text { before surgery }\end{array}$ & 52.8 \\
* Scores $0-5$ ( 5 meaning totally satisfied). &
\end{tabular}

Table 7. Daytime and Night Driving Driving Scale Score

\begin{tabular}{lcc}
\hline Uncorrected Vision & Mean $\pm \mathrm{SD}$ or $\%$ & Range \\
\hline Mean score & $3.0 \pm 0.9$ & $1.1-4.9$ \\
Driving permit & 96.5 & \\
Daytime driving score of 5 (totally satisfied) & 62.3 & \\
Night driving score of 5 (totally satisfied) & 8.0 & \\
More difficulty with night driving than before surgery & 40.9 & \\
Less difficulty with night driving than before surgery & 51.0 & \\
*Scores 0-5 (5 meaning totally satisfied). & &
\end{tabular}

Correlations between satisfaction scales and clinical parameters.

Visual acuity. The mean postoperative logMAR UCVA in the best eye at the time of the questionnaire was $-.027 \pm .11$ and showed a correlation with overall satisfaction, the uncorrected vision score, the night vision score and the driving scores (Table 8).

Refraction. The mean postoperative spherical equivalent (SE) was $-0.17 \pm 0.36$ D. In the population, $86.8 \%$ was within $\pm 0.5 \mathrm{D}$, and $97.0 \%$ was within $\pm 1.0 \mathrm{D}$ from emmetropia, respectively. There was no correlation between the satisfaction scores and the degree of preoperative SE. A significant correlation was found between the SE at the last follow-up (LFU) and the uncorrected vision score and the driving scores (Figure 1). The mean refractive astigmatism value at the LFU showed a correlation with the uncorrected vision score (Figure 2) and the driving scores.

The mean preoperative and postoperative simulated keratometry values of the steep and flat meridians were $44.10 \mathrm{D} \pm 1.73$ and $42.78 \mathrm{D} \pm 1.66$, and $40.0 \mathrm{D} \pm 2.05$ and $39.1 \mathrm{D} \pm 2.01$, respectively. There were no significant associations between these keratometry values and the satisfaction scores. The mean preoperative and 


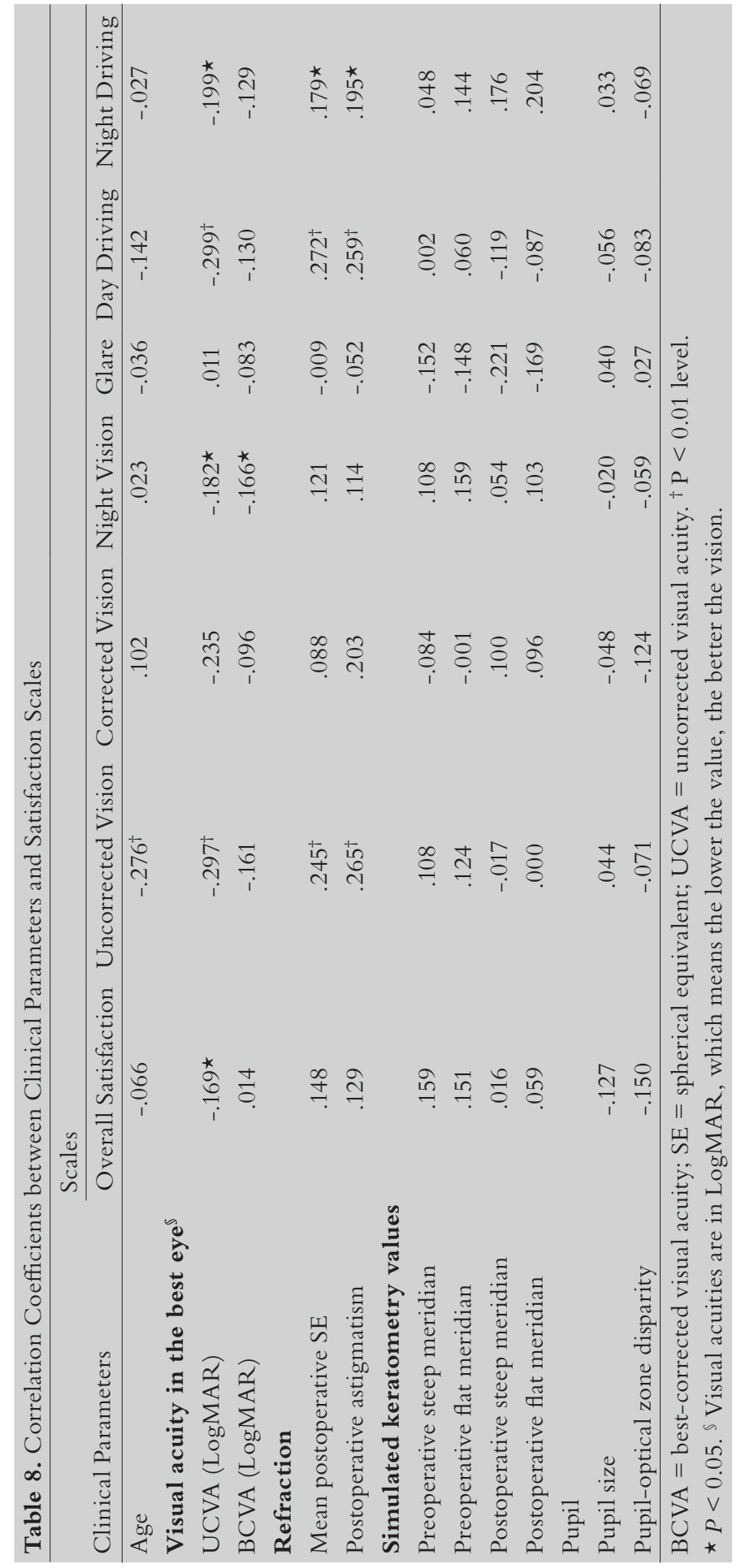


postoperative topographical astigmatism values did not correlate with the glare or night vision scores.

Ablation depth. The mean ablation depth used during surgery was $90.7 \pm 37.0$ $\mu \mathrm{m}$. No significant correlation was observed between the night vision score and the ablation depth $(\mathrm{r}=-.55, P=.515)$ nor between the glare score and the ablation depth $(\mathrm{r}=.083, P=.328)$.

Pupil size and pupil-optical zone disparity. Mean scotopic pupil sizes were $6.0 \pm .83 \mathrm{~mm}$. No significant correlation was found between the scotopic pupil size or the pupil-optical zone disparity and any of the satisfaction scores (Figures 3 and 4).

\section{Wavefront-guided LASIK group}

For the separate small group of 11 binocular wavefront-guided LASIK patients, the mean postoperative logMAR UCVA in the best eye at the time of the questionnaire was $-0.072 \pm .08$. The mean postoperative SE was $-0.11 \pm 0.24 \mathrm{D}$ and showed a correlation with the global satisfaction score $(r=.66, P=.026)$. The mean preoperative and postoperative simulated keratometry values of the steep and flat meridians were 43.96 D \pm 2.24 and $42.57 \mathrm{D} \pm 2.37$, and $38.81 \mathrm{D} \pm 1.98$ and $38.01 \mathrm{D} \pm 2.04$, respectively. No correlation was found between the glare or night vision scores and the degree of correction, the ablation depth or the pupil-optical zone disparity. 


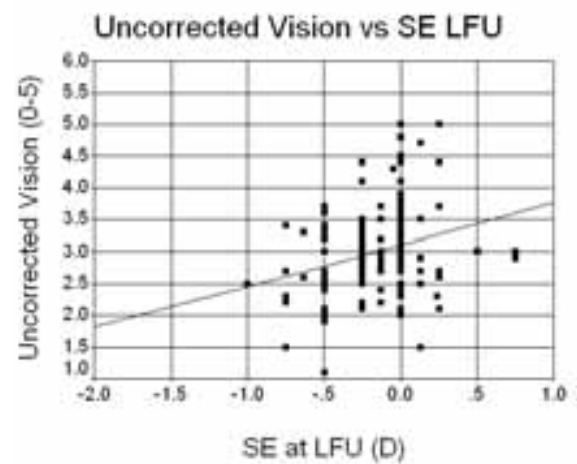

Figure 1. Uncorrected vision score versus postoperative spherical equivalent (SE) at last follow-up (LFU); $\mathrm{r}=.245, P=.003$

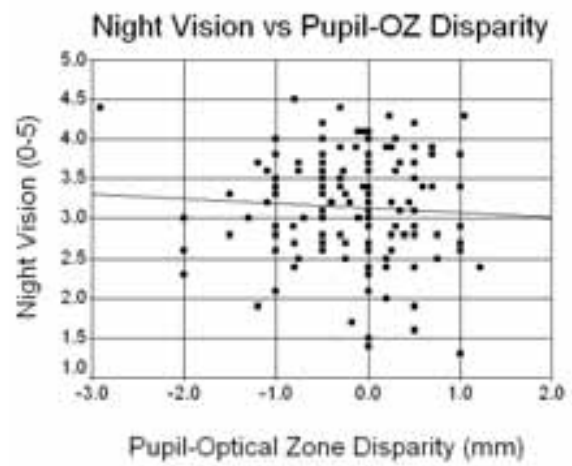

Figure 3. Night vision score versus the pupil-optical zone (OZ) disparity; $\mathrm{r}=-.059, P=.488$

\section{Uncorrected Vision vs Cylinder LFU}

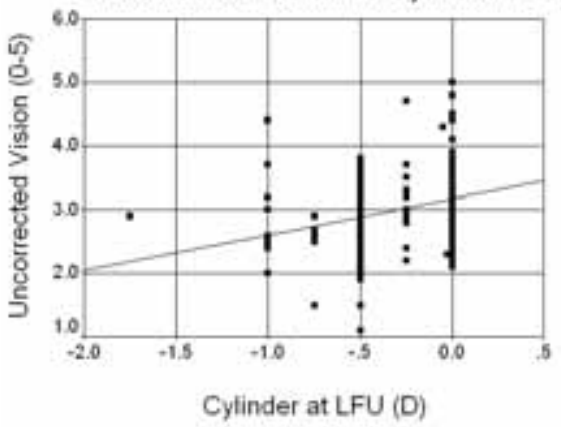

Figure 2. Uncorrected vision score versus postoperative astigmatism value at last follow-up (LFU); $\mathrm{r}=.284, P=.001$

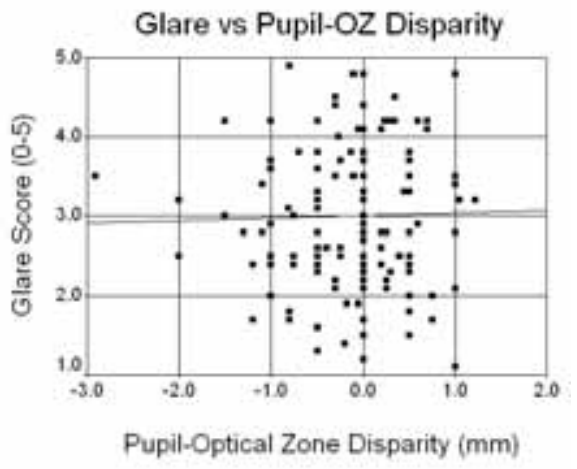

Figure 4. Glare score versus the pupiloptical zone (OZ) disparity; $\mathrm{r}=.027, P=.753$ 


\section{DISCUSSION}

Overall, many reports have shown excellent medical outcome in terms of predictability, efficacy and safety after LASIK. ${ }^{6,19-25}$ Consequently, this has led to high patient satisfaction rates which range from $82 \%$ to $98 \%$ in recent studies. ${ }^{3-6}$ Patient satisfaction has been shown to remain high, also beyond the initial 6-month follow-up period. ${ }^{26}$

Our study likewise showed an excellent medical outcome with a good predictability and $86.8 \%$ of eyes within $\pm 0.5 \mathrm{D}$ and $97.0 \%$ within $\pm 1.0 \mathrm{D}$ from emmetropia. The mean score for the overall satisfaction was $4.10 \pm 0.71$ on a scale of 0 to 5 (a score of 5 meaning that the patient was totally satisfied). More than $90 \%$ of patients felt that their main goal of surgery had been achieved and would make the same decision if they could do it all over again. We observed direct correlations between subjective quality of vision scale scores and clinical parameters. The uncorrected vision score was directly correlated with the mean postoperative SE and the mean postoperative refractive astigmatism. In general, patients were more satisfied with a postoperative SE close to emmetropia. Similar findings have been shown in a previous study. ${ }^{1,2}$

Our study did not show a relation between increased age and decreased overall satisfaction. However, similar to previous studies, there was a relation between increased age and lower uncorrected vision scores. . $^{4,10}$

Despite excellent medical outcome results and high patient satisfaction, quality of vision problems such as NVCs, glare and halos remain a problem. These problems have been reported in many clinical studies after refractive surgery, ranging from $12 \%$ to $57 \%$ in patients. $2,6,10,11,27,28$ NVCs and problems from glare often diminish after the first six postoperative months. ${ }^{8}{ }^{10}$ In our study patients also appeared to have significant NVCs presenting as glare and affecting night driving. But, despite the high score of NVCs, $92.3 \%$ of patients reported that they would choose the same type of surgery again if they had to make their choice a second time. A possible explanation is that this is the result of a gradual adaptation to a new condition. Patients who wore rigid gas-permeable contact lenses and glasses before surgery might show an easier acceptance and an increased level of tolerance to glare and halos (57\% of patients reported to have worn rigid gas permeable contact lenses at least six months preoperatively). ${ }^{2}$ Another hypothesis is that patients get used to their altered night vision, with a consequential decrease in reported NVCs as shown in a previous study, which showed that NVCs decreased significantly over the first postoperative year. ${ }^{10}$

Our study used a questionnaire which was self-administered by our patients, after they were sent to them by an independent physician, without verbal encouragement. We feel that self-administered tests, rather than physician-administered tests, enable a more objective view of patient satisfaction and quality of vision. When a test is administered by a physician, results may be biased and patients might feel compelled to always answer in the affirmative. ${ }^{2}$ 
A limitation in our study was the lack of a more uniform postoperative interval for administering the questionnaire to our patients. Patient perception changes over time, due to both psychological factors and corneal healing. In addition to this, a longer follow up time makes it more difficult for a patient to accurately compare his / her preoperative and current quality of vision. A more proper analysis would have been made through administering the questionnaire preoperatively and again at a uniform postoperative interval.

Previous studies have designated the pupil size as a significant predictor of glare and halos after LASIK, especially in the first postoperative month. ${ }^{8,17,29}$ However, at six months postoperatively pupil size was not found to be a significant predictor anymore. ${ }^{8}$ Large pupils tend to increase the exposure of corneal aberrations, which can reduce visual acuity in LASIK patients and untreated patients as well. ${ }^{30,31}$ Smaller pupils have been associated with improved vision in patients after refractive surgery and in untreated patients. ${ }^{32}$ Although a thorough literature review on PRK and LASIK strongly suggests that a large pupil in combination with a small optical zone is a dominant factor leading to increased NVCs, ${ }^{33}$ recent data show that the correlation between pupil size and NVCs or between NVCs and the pupil-optical zone disparity is much less critical than previously thought. ${ }^{2,6}$, $8-10,12,33$ Similar to these studies, our study of primarily conventional treatments and a small subset of wavefront-guided treatments, also showed no significant correlation between pupil size and glare or NVCs.

Therefore, we feel that the precise role of pupil size and its exact relation to NVCs still remains unknown and controversial. Although pupil size quantification has been previously described by various authors, further development and standardization of preoperative pupil size measurements is imperative to better define the exact role of pupil size in NVCs. ${ }^{2,9,10,16,18,33-35}$ Objective quantification of NVCs also needs further elaboration, which remains difficult and faces us with challenges and limitations concerning the precise analysis of its nature. Previous authors have questioned whether the risk of NVCs is really attributable to LASIK or whether the general population has the same prevalence of NVCs. Questions have also arisen as to the possible roles of changes in the transition zone and of central neural adaptation in the slow decrease of NVCs. ${ }^{2,}{ }^{36}$ Finally, the contribution of flap size and centration issues related to NVCs have been questioned. ${ }^{6,9,10,12}$

In contrast to an earlier study, we found no correlation between the glare or night vision scores and the preoperative and postoperative corneal curvatures. ${ }^{6} \mathrm{We}$ did show a correlation between the uncorrected vision score and the postoperative SE and refractive astigmatism values: the lower the postoperative residual refractive error was, the happier our patients were with their self-perceived uncorrected vision.

Interestingly, our results show that the mean score for patients wearing glasses for quality of daytime vision $(2.95 \pm 1.08)$ was slightly lower than the mean score for night vision for all patients $(3.1 \pm 0.7)$. This might be partially explained by the fact that these patients' expectations were not fulfilled, i.e. to be spectacle- 
independent postoperatively, and therefore rated their satisfaction with their daytime vision as less.

In conclusion, our study demonstrates high patient satisfaction after LASIK surgery for the correction of myopia and myopic astigmatism. We show that this can be achieved when we aim for a postoperative SE close to emmetropia in combination with low residual postoperative astigmatism. No relation was found between the glare or night vision scores and the degree of correction, ablation depth or pupil-optical zone disparity. We agree with previous authors that further investigation needs to be done as to the objective quantification of pupil size and the assessment of NVCs. 


\section{REFERENCES}

1. Brunette I, Gresset J, Boivin JF, et al. Functional outcome and satisfaction after photorefractive keratectomy. Part 1: development and validation of a survey questionnaire. Ophthalmology 2000;107(9):1783-9.

2. Brunette I, Gresset J, Boivin JF, et al. Functional outcome and satisfaction after photorefractive keratectomy. Part 2: survey of 690 patients. Ophthalmology 2000;107(9):1790-6.

3. Marinho A, Pinto MC, Pinto R, et al. LASIK for high myopia: one year experience. Ophthalmic Surg Lasers 1996;27(5 Suppl):S517-20.

4. McGhee CN, Craig JP, Sachdev N, et al. Functional, psychological, and satisfaction outcomes of laser in situ keratomileusis for high myopia. J Cataract Refract Surg 2000;26(4):497-509.

5. Knorz MC, Wiesinger B, Liermann A, et al. Laser in situ keratomileusis for moderate and high myopia and myopic astigmatism. Ophthalmology 1998;105(5):932-40.

6. Bailey MD, Mitchell GL, Dhaliwal DK, et al. Patient satisfaction and visual symptoms after laser in situ keratomileusis. Ophthalmology 2003;110(7):1371-8.

7. Nuijts RM, Nabar VA, Hament WJ, Eggink FA. Wavefront-guided versus standard laser in situ keratomileusis to correct low to moderate myopia. J Cataract Refract Surg 2002;28(11):1907-13.

8. Schallhorn SC, Kaupp SE, Tanzer DJ, et al. Pupil size and quality of vision after LASIK. Ophthalmology 2003;110(8):1606-14.

9. Probst LE. The problem with pupils. J Cataract Refract Surg 2004;30(1):2-4.

10. Pop M, Payette Y. Risk factors for night vision complaints after LASIK for myopia. Ophthalmology 2004;111(1):3-10.

11. Hammond SD, Jr., Puri AK, Ambati BK. Quality of vision and patient satisfaction after LASIK. Curr Opin Ophthalmol 2004;15(4):328-32.

12. Klyce SD. Night vision after LASIK: the pupil proclaims innocence. Ophthalmology 2004;111(1):1-2.

13. Lee YC, Hu FR, Wang IJ. Quality of vision after laser in situ keratomileusis: influence of dioptric correction and pupil size on visual function. J Cataract Refract Surg 2003;29(4):769-77.

14. Perez-Santonja JJ, Sakla HF, Alio JL. Contrast sensitivity after laser in situ keratomileusis. J Cataract Refract Surg 1998;24(2):183-9.

15. Mutyala S, McDonald MB, Scheinblum KA, et al. Contrast sensitivity evaluation after laser in situ keratomileusis. Ophthalmology 2000;107(10):1864-7.

16. Kohnen T, Terzi E, Buhren J, Kohnen EM. Comparison of a digital and a handheld infrared pupillometer for determining scotopic pupil diameter. J Cataract Refract Surg 2003;29(1):112-7.

17. Holladay JT, Dudeja DR, Chang J. Functional vision and corneal changes after laser in situ keratomileusis determined by contrast sensitivity, glare testing, and corneal topography. J Cataract Refract Surg 1999;25(5):663-9. 
18. Colvard M. Preoperative measurement of scotopic pupil dilation using an office pupillometer. J Cataract Refract Surg 1998;24(12):1594-7.

19. Pallikaris IG, Siganos DS. Excimer laser in situ keratomileusis and photorefractive keratectomy for correction of high myopia. J Refract Corneal Surg 1994;10(5):498-510.

20. Perez-Santonja JJ, Bellot J, Claramonte P, et al. Laser in situ keratomileusis to correct high myopia. J Cataract Refract Surg 1997;23(3):372-85.

21. Tsai RJ. Laser in situ keratomileusis for myopia of -2 to -25 diopters. J Refract Surg 1997;13(5 Suppl):S427-9.

22. Pesando PM, Ghiringhello MP, Tagliavacche P. Excimer laser in situ keratomileusis for myopia. J Refract Surg 1997;13(6):521-7.

23. Lindstrom RL, Hardten DR, Chu YR. Laser In Situ keratomileusis (LASIK) for the treatment of low moderate, and high myopia. Trans Am Ophthalmol Soc 1997;95:285-96; discussion 96-306.

24. Hersh PS, Brint SF, Maloney RK, et al. Photorefractive keratectomy versus laser in situ keratomileusis for moderate to high myopia. A randomized prospective study. Ophthalmology 1998;105(8):1512-22, discussion 22-3.

25. Yang CN, Shen EP, Hu FR. Laser in situ keratomileusis for the correction of myopia and myopic astigmatism. J Cataract Refract Surg 2001;27(12):1952-60.

26. Bailey MD, Mitchell GL, Dhaliwal DK, et al. Reasons patients recommend laser in situ keratomileusis. J Cataract Refract Surg 2004;30(9):1861-6.

27. Brown SM, Khanani AM. Night vision complaints after LASIK. Ophthalmology 2004;111(8):1619-20; author reply 920.

28. Salz JJ, Boxer Wachler BS, Holladay JT, Trattler W. Night vision complaints after LASIK. Ophthalmology 2004;111(8):1620-1; author reply 1-2.

29. el Danasoury MA. Prospective bilateral study of night glare after laser in situ keratomileusis with single zone and transition zone ablation. J Refract Surg 1998;14(5):512-6.

30. Moreno-Barriuso E, Lloves JM, Marcos S, et al. Ocular aberrations before and after myopic corneal refractive surgery: LASIK-induced changes measured with laser ray tracing. Invest Ophthalmol Vis Sci 2001;42(6):1396-403.

31. Boxer Wachler BS, Huynh VN, El-Shiaty AF, Goldberg D. Evaluation of corneal functional optical zone after laser in situ keratomileusis. J Cataract Refract Surg 2002;28(6):948-53.

32. Wachler BS, Hiatt D, Chou B, Christie JP. Reduction of pupil size and halos with minus lenses after laser in situ keratomileusis. J Refract Surg 2004;20(2):149-54.

33. Fan-Paul NI, Li J, Miller JS, Florakis GJ. Night vision disturbances after corneal refractive surgery. Surv Ophthalmol 2002;47(6):533-46.

34. Colvard M. Defining mesopic and scotopic. J Cataract Refract Surg 2003;29(1):6-7.

35. Periman LM, Ambrosio R, Jr., Harrison DA, Wilson SE. Correlation of pupil sizes measured with a mesopic infrared pupillometer and a photopic topographer. J Refract Surg 2003;19(5):555-9.

36. Wilson SE. Wave-front analysis: are we missing something? Am J Ophthalmol 2003;136(2):340-2. 
Functional outcome and patient satisfaction after Artisan phakic intraocular lens implantation for
correction of myopia

Tahzib NG, Eggink FAGJ, Nuijts RMMA.

Am J Ophthalmol. 2006 Jul;142(1):31-39. 


\section{ABSTRACT}

Purpose: To determine patient satisfaction after Artisan phakic intraocular lens (PIOL) implantation to correct myopia.

Design: Non-comparative prospective case-series.

Methods: One hundred and twenty eyes of 60 patients who had undergone Artisan PIOL implantation to correct myopia were analyzed. A validated questionnaire consisting of 66 satisfaction items were self-administered by patients 12 months after surgery. Clinical parameters (PIOL decentration, the difference between pupil size and PIOL optical zone and optical aberrations) were measured. Main outcome measures were satisfaction scale scores (global satisfaction, quality of uncorrected and corrected vision, night vision, glare, day and night driving) and were analyzed. Correlations with clinical parameters were obtained.

Results: After surgery, $98.3 \%$ of patients were satisfied and $73.3 \%$ considered their night vision to be the same or better; $44.1 \%$ reported more bothersome glare. The night vision score correlated with spherical aberration $(\mathrm{r}=-0.303, P=0.020)$. The glare score correlated with the difference between scotopic pupil size and PIOL optical zone $(r=-0.280$, $P=0.030)$ and vertical coma $(\mathrm{r}=-0.337, P=0.009)$. The night driving score correlated with postoperative spherical equivalent $(\mathrm{r}=0.375, P=0.009)$, total root mean square aberrations $(\mathrm{RMS})(\mathrm{r}=-0.337, \mathrm{P}=0.017)$, higher order RMS $(\mathrm{r}=-0.313, P=0.027)$ and vertical coma $(\mathrm{r}=-0.297, P=0.036)$.

Conclusion: Overall satisfaction after Artisan PIOL implantation for myopia is excellent. The quality of night vision and night driving were related to scotopic pupil size, individual higher order aberrations and residual refractive error. 


\section{INTRODUCTION}

In general, high levels of patient satisfaction are reported after refractive surgery including photorefractive keratectomy (PRK), laser assisted in situ keratomileusis (LASIK) $)^{1-8}$ and phakic intraocular lens implantation (PIOL). ${ }^{9}{ }^{10}$ However, numerous studies have outlined a decreased quality of vision after refractive surgery which may be attributed to contrast sensitivity loss and subsequent night vision complaints (NVCs). Proposed mechanisms for this decrease in quality of vision have been the use of small optical zones in patients with large preoperative scotopic pupil sizes and highly oblate corneal profiles after laser surgery., ${ }^{2,114}$ After corneal laser surgery it may be difficult to determine the exact effective optical zone size due to variations in the transition zones of current excimer lasers. Therefore, it is often difficult to establish the disparity between the optical zone size and the scotopic pupil size. In addition, in contrast to previous assumptions, several recent reports show that a large pupil size is probably not a major risk factor for NVCs after LASIK surgery., ${ }^{4,14,15}$

The purpose of this study was to assess patient satisfaction and to determine possible risk factors for the development of NVCs after Artisan PIOL implantation. The Artisan PIOL is a lens with a fixed optical zone of 5 or $6 \mathrm{~mm}$, depending on the dioptric power of the lens, and is used for the correction of moderate to severe myopia. The risk factors that were investigated included the preoperative pupil size under dim light conditions, the disparity between the pupil size and the optical zone of the PIOL and the decentration of the PIOL. The presence of postoperative higher order aberrations (HOAs) was also assessed.

\section{PATIENTS AND METHODS}

\section{Questionnaire and study design}

The study and data accumulation were carried out with approval from the Institutional Review Board from the Academic Hospital Maastricht, the Netherlands. The questionnaire used in our study was developed and validated by Brunette et al. and has been previously used for the evaluation of patient satisfaction after PRK and to assess postoperative visual symptoms., 16 The questionnaire was translated into the Dutch language from the original English without changes to the contents and construction of the original questionnaire. Later it was translated back into English, after which original and backtranslated versions were compared and minor inconsistencies were corrected. The instrument has proven to be reliable by a high level of internal consistency with Cronbach's alpha coefficients superior or equal to $0.83 .5,16$ In the questionnaire, 66 items were selfadministered by the patients 12 months after the PIOL implantation procedure. For analysis purposes, these items were reformulated by applying factor analysis 
into seven distinct scales. ${ }^{16}$ Scale scores increased with satisfaction, ranging from 1 (very dissatisfied) to 5 (very satisfied). Each of the seven scales covered a specific aspect of quality of vision, including global satisfaction, quality of uncorrected and corrected vision, quality of night vision, glare, daytime driving and night driving.

Before the routine examination, the questionnaire was provided to the patient by an independent employee who had no interest or involvement with the patient and whom requested him / her to fill in the questionnaire. Patients were informed about the study procedure and provided informed consent.

\section{Surgical procedure}

All treatments were performed by a single surgeon (R.N.) at the Academic Center for Refractive Surgery, University Eye Clinic of Maastricht.

Exclusion criteria were a preoperative best-corrected visual acuity (BCVA) < 20/50, an anterior chamber depth $<3.0 \mathrm{~mm}$ (determined by immersion A-scan biometry method), an endothelial cell count lower than 2000 cells $/ \mathrm{mm}^{2}$ (Noncon ROBO Pachy SP-9000, Konan Medical Inc, Tokyo, Japan), glaucoma and retinal pathology.

The Artisan iris claw-fixated PIOL has a convex-concave polymethyl methacrylate optic with either a $6-\mathrm{mm}$ (for intraocular lens powers up to $-15.5 \mathrm{D}$ ) or a $5-\mathrm{mm}$ (for intraocular lens powers from $-16.0 \mathrm{D}$ up to $-24.0 \mathrm{D}$ ) and is available in 0.50 D steps (Ophtec B.V., Groningen, the Netherlands). Refractive error, refractive cylinder power, anterior chamber depth, and topographically derived keratometric dioptric values (Orbtek Orbscan II, version 3.10.31, Bausch \& Lomb, Munich, Germany) were inserted into the Van der Heijde formula to calculate the dioptric power of the lens. ${ }^{17}$ The power of the lens was chosen to obtain emmetropia. When the emmetropic lens was not available, the power of the lens was estimated for a slight residual myopia.

Surgery was performed under general anaesthesia. A two-plane 6.3 or $5.3 \mathrm{~mm}$ corneoscleral incision was centered at 12-o'clock. Two stab-incisions were performed at 2 and 10 o'clock and directed towards the enclavation sites. After an intracameral injection of acetylcholine and the insertion of a viscoelastic substance (Healon GV, Pharmacia, Uppsala, Sweden), the lens was introduced with a Budo forceps (Duckworth and Kent, Ltd, Baldock Herts, England). After subtle rotation of the lens, it was fixated in the horizontal axis with the use of a disposable enclavation needle (Ophtec BV, Groningen, Netherlands). A slit iridotomy was performed at 12 o'clock to avoid pupillary block glaucoma. The viscoelastic substance was exchanged for balanced salt solution (Alcon, Fort Worth, Texas). The wound was sutured with 3 to 5 interrupted 10-0 nylon sutures (Alcon, Fort Worth, Texas). Postoperatively, topical tobramycin 0.3\% combined with dexamethasone $0.1 \%$ (Tobradex, Alcon, Couvreur, Belgium) and ketorolactrometamol 0.5\% (Acular, Westport Co., Mayo, Ireland) were used four 
times daily for 3 weeks in a tapered schedule and three times daily for 1 week, respectively. Selective suture removal was performed depending on the subjective refraction.

A surgical delay of one month between both eyes was established for all patients. Included patients showed a stable postoperative refraction and were examined preoperatively and at day 1 , week 1 , month 1 , month 3 , month 6 , and from then at 6-month intervals. The routine examination consisted of the measurement of the Snellen UCVA and BCVA using subjective and manifest refraction, corneal topography, and intraocular pressure measurement with Goldmann applanation tonometry. Because no binocular visual acuity measurement was available, the UCVA and BCVA of the best eye were used for all calculations. When scales such as night vision, glare and night driving were assessed, the UCVA and BCVA of the worst eye were used.

\section{Pupil and wavefront measurements}

The scotopic and mesopic-low pupil size was measured with a digital infrared pupillometer (P2000 SA pupillometer, Procyon Instruments Ltd., London, UK). This device performs binocular simultaneous measurements of the pupil diameter at 3 illuminance levels (scotopic [0.04 lux], mesopic-low [0.4 lux], and mesopichigh [4.0 lux]). At each illuminance level, a sequence of 10 images is acquired within 2 seconds and stored in a portable computer. ${ }^{18}$

Wavefront measurements were performed with a Hartmann-Shack wavefront sensor (Zywave aberrometer, software version 3.21, Bausch \& Lomb-Technolas, Munich, Germany). The Zywave aberrometer uses a wavelength of $780 \mathrm{~nm}$ and an array of approximately 70 to 75 lenslets. Three Zywave measurements were taken under standardized mesopic light conditions after installation of phenylephrine 5\% (Bournonville Pharma BV, the Hague, the Netherlands) and analyzed using the provided software. To avoid instrument accommodation, the eye is fogged about 1.0 diopter (D) during measurements. Wavefront errors were described using Zernike polynomials for a virtual pupil diameter of $6 \mathrm{~mm}$ that resembles pupil size under mesopic conditions. The Zywave measurements allow a Zernike approximation from second order to fifth order for 6-mm pupils. The aberrations used in this study are classified in terms of total root mean square aberrations (total RMS) of the wavefront error and higher-order aberrations (HOAs), including total higher order root mean square (total HO-RMS) of the wavefront error, horizontal coma $\left(Z_{3}{ }^{1}\right)$, vertical coma $\left(Z_{3}{ }^{-1}\right)$, trefoil-x $\left(Z_{3}{ }^{3}\right)$, trefoil-y $\left(Z_{3}{ }^{-3}\right)$ and spherical aberration $(\mathrm{SA})\left(\mathrm{Z}_{4}{ }^{0}\right) \cdot{ }^{19-21}$

Data analysis

LogMAR values of the UCVA and the BCVA of the best eye were used for calculations. 
The amount of decentration of the PIOL was determined by measuring the deviation of the center of the PIOL from the center of the pupil using the digital photography mode within the Zywave aberrometer. The pupil-optical zone disparity, which is defined as the disparity between the pupil size and the optical zone of the PIOL, was calculated by subtracting the optical zone of the PIOL from the scotopic and mesopic-low pupil size as measured by the Procyon

pupillometer. For parameters expected to have an adverse effect in relation to glare and NVCs, such as preoperative pupil size, the pupil-optical zone disparity, and the decentration of the PIOL, the greatest value of both eyes were taken for analysis. Wavefront analysis was performed for pupil diameters of $6.0 \mathrm{~mm}$. Zernike coefficients up to the 4th order are currently included in the measurements. Calculations were performed using total RMS, total HO-RMS, horizontal coma, vertical coma, trefoil-x, trefoil-y and SA. Changes in the quality of vision scale scores were determined by defining correlations with total HOAs and individual HOAs.

For statistical analyses, results from the wavefront examinations were transformed into absolute values and Snellen visual acuities were transformed to LogMAR values.

Correlations between the scale scores and clinical parameters were performed for data obtained at the 12 month follow-up examination and assessed with the Pearson $r$ coefficient of correlation and the Spearman rank correlation (SPSS for Windows, SPSS Inc., Chicago, IL). The Mann-Whitney test was used to compare satisfaction score differences between spectacle and non-spectacle or contact lens wearers before or after surgery. The ANOVA test was used to compare differences between patient age and the satisfaction scales. All values in the text are mean \pm standard deviation (SD).

\section{RESULTS}

A total of a hundred and twenty eyes of 60 consecutive patients were included in this study. The patient group consisted of 39 females (65\%) and 21 males (35\%). Population characteristics and scale scores are listed in Tables 1 and 2. Data were provided only for patients subjected to the particular condition.

Patient satisfaction and self-perceived outcome. Before surgery, $71.7 \%$ of patients wore contact lenses on a regular basis. The most frequently reported motivations for desiring surgical correction were a general dislike of handling glasses $(33.9 \%)$, intolerance to contact lens wear (18.6\%), to be less dependent on glasses $(15.3 \%)$, and a dislike of handling contact lenses $(6.8 \%)$.

Global satisfaction. The mean overall satisfaction score was $4.22 \pm .56$ (5 meaning totally satisfied). The majority of patients $(96.7 \%)$ reported that their main goal of surgery had been achieved; $98.3 \%$ of patients were satisfied or very satisfied with the result of surgery; $98.3 \%$ reported that the surgery had been a 
Table 1. Characteristics of Patient Population who received Artisan Phakic Intraocular Lens Implantation for the Correction of Myopia.

\begin{tabular}{|c|c|c|c|}
\hline Characteristics & $\begin{array}{c}\text { Mean } \pm \text { SD } \\
\text { or } \% \text { of patients }\end{array}$ & Median & Range \\
\hline Age (yrs) & $44.3 \pm 8.7$ & 45.0 & 26 to 63 \\
\hline Female & $65.0 \%$ & & \\
\hline \multicolumn{4}{|l|}{ Before surgery ( $n=120$ eyes of 60 patients) } \\
\hline Mean sphere $(\mathrm{D})$ & $-11.14 \pm 3.99$ & -10.50 & -24.50 to -4.75 \\
\hline Mean cylinder (D) & $-0.97 \pm 0.89$ & -0.75 & -4.25 to 0.75 \\
\hline Mean SE (D) & $-12.09 \pm 4.09$ & -10.88 & -5.63 to -27.25 \\
\hline$-12.00 \leq \mathrm{SE}<-5.63$ & $61.7 \%$ & & \\
\hline$-18.00 \leq \mathrm{SE}<-12.00$ & $30.0 \%$ & & \\
\hline$-27.25 \leq \mathrm{SE}<-18.00$ & $8.3 \%$ & & \\
\hline BCVA $20 / 20$ or better & $44.0 \%$ & & \\
\hline BCVA between 20/20 and 20/40 & $39.9 \%$ & & \\
\hline BCVA $20 / 40$ or worse & $16.1 \%$ & & \\
\hline Mean pupil diameter (mm) (scotopic) & $6.2 \pm 0.79$ & 6.2 & 4.6 to 7.6 \\
\hline \multicolumn{4}{|c|}{ At 12 months FU ( $\mathrm{n}=120$ eyes of 60 patients) } \\
\hline UCVA $20 / 20$ or better & $25.8 \%$ & & \\
\hline UCVA between $20 / 20$ and $20 / 40$ & $42.5 \%$ & & \\
\hline UCVA $20 / 40$ or worse & $31.7 \%$ & & \\
\hline Loss of 1 Snellen line of BCVA & $5.8 \%$ & & \\
\hline Loss of 2 Snellen lines of BCVA & $0.8 \%$ & & \\
\hline Gain of 2 Snellen lines or more of BCVA & $23.3 \%$ & & \\
\hline \multicolumn{4}{|c|}{ At 12 months FU ( $n=120$ eyes of 60 patients) } \\
\hline \multicolumn{4}{|l|}{ Refractive outcome } \\
\hline Mean SE (D) & $-0.60 \pm 0.78$ & -0.50 & -3.50 to 0.75 \\
\hline Mean SE $\pm 0.50 \mathrm{D}$ of emmetropia & $62.4 \%$ & & \\
\hline Mean SE $\pm 1.00 \mathrm{D}$ of emmetropia & $81.5 \%$ & & \\
\hline
\end{tabular}

Table 2. Scale Scores Descriptives after Artisan Phakic Intraocular Lens Implantation for the Correction of Myopia.

\begin{tabular}{lcc}
\hline Scale & Mean $\pm \mathrm{SD}^{\star}$ & Range \\
\hline Global satisfaction & $4.2 \pm 0.56$ & $1.9-5.0$ \\
Uncorrected daytime vision & $3.2 \pm 0.87$ & $1.6-5.0$ \\
Corrected daytime vision & $3.5 \pm 0.90$ & $2.0-5.0$ \\
Night vision & $3.2 \pm 0.65$ & $1.6-4.4$ \\
Glare & $3.0 \pm 0.84$ & $1.4-5.0$ \\
Daytime driving & $4.7 \pm 0.87$ & $1.0-5.0$ \\
Night driving & $3.2 \pm 1.31$ & $1.0-5.0$ \\
\hline
\end{tabular}

*Scores 0-5 (5 meaning totally satisfied). SD $=$ standard deviation. 
good choice for them; $93.3 \%$ postoperatively experienced a quality of vision as they had expected; for $70.0 \%$ of patients, the best consequence of surgery was that they no longer felt dependent on their glasses or contact lenses. After surgery, no significant difference in global satisfaction was shown between patients wearing spectacles or contact lenses for distance vision $(4.12 \pm 0.64, \mathrm{n}=36)$ and those who did not wear any type of correction $(4.35 \pm 0.44, \mathrm{n}=24)$ before surgery.

Quality of daytime vision without correction. The mean score was 3.20 $\pm 0.87 ; 50.0 \%$ of patients reported that after surgery their self-perceived uncorrected vision for distance was slightly or much better than their preoperative corrected vision, $21.7 \%$ of patients considered it the same and $28.3 \%$ of patients reported it as being slightly or much worse.

Uncorrected near vision was characterized as slightly or much better than the preoperative corrected near vision by $28.3 \%$ of patients, the same by $37.3 \%$ of patients and slightly or much worse by $35.0 \%$ of patients.

Quality of daytime vision with correction. The majority of patients (73.3\%) wore contact lenses before surgery; $26.7 \%$ of patients wore spectacles. After surgery, regular use of glasses for distance vision and near vision and of contact lenses was reported by $38.3 \%(n=23)$ and $38.3 \%(n=23)$, and $1.7 \%(n=1)$ of patients, respectively. The mean score for patients wearing glasses for quality of daytime vision was $3.47 \pm 0.90$. There was no correlation between the corrected vision score and patient age $(\mathrm{r}=-0.289, P=0.087)$.

Quality of night vision. The mean night vision score was $3.16 \pm 0.65$. After surgery, $58.4 \%$ of patients were satisfied with their night vision. In comparison to before surgery, $73.3 \%$ of patients considered their night vision after surgery to be the same or better; $26.7 \%$ of patients considered it to be worse or much worse. NVCs after surgery included perception of stars around lights (41.7\%), halos, fog, or haze around street lights (48.4\%), double outline of images (6.7\%), ghost images $(8.3 \%)$, and distortion of details $(33.3 \%)$. Patients recalled such symptoms before surgery in $33.3 \%, 35.0 \%, 6.6 \%, 6.7 \%$ and $21.6 \%$ of cases, respectively.

Glare. The mean glare score was $3.02 \pm 0.84$. Only one patient $(1.7 \%)$ showed a score of 5 for the glare scale (totally satisfied). Patients reported glare or light sensitivity on sunny days, snowy weather conditions, foggy conditions, or when going from dim to bright light conditions in 50.8\%, 42.6\%, 12.5\% and $35.0 \%$, respectively. After surgery, daytime glare and glare from lights at night were considered more bothersome than before surgery by $32.8 \%$ and $44.1 \%$ of patients, respectively. Glare from oncoming car headlights was reported by $68.4 \%$ and believed to be more bothersome for night driving than before surgery by $55.8 \%$.

Driving. A total of 51 patients (85.0\%) reported driving a car. The mean daytime driving score was $4.66 \pm 0.87$. The mean night driving score was $3.22 \pm 1.31$. A daytime and night driving score of 5 was reported by $80.4 \%$ and $15.7 \%$ of patients, respectively. 
After surgery, $51 \%$ of patients reported to experience night driving problems, while $39.2 \%$ of patients reported having more difficulty during night driving than before surgery and $56.9 \%$ of patients reported having less difficulty.

\section{Correlations between Satisfaction Scales and Clinical Parameters.}

Visual acuity. At the 12 month follow-up, 25.8\% of eyes had an UCVA of $20 / 20$ or better and $76.6 \%$ had a UCVA of $20 / 40$ or better (Table 1). Preoperatively, $44.0 \%$ had a BCVA of better than 20/20 and $90.6 \%$ had a BCVA of 20/40 or better. There was a loss of 1 Snellen line of BCVA in $5.0 \%$ of eyes and a loss of 2 Snellen lines of BCVA in $0.8 \%$ of eyes. In addition, there was a gain of at least 2 Snellen lines of BCVA in $23.3 \%$ of eyes.

The mean LogMAR UCVA of the best eye at the time of the questionnaire was $0.14 \pm 0.17$ and showed a correlation with the uncorrected vision score $(\mathrm{r}=$ $-0.346, P=0.007$ ) (Table 3) (Figure 1). The mean preoperative LogMAR BCVA of the best eye was $0.07 \pm 0.12$ and did not correlate with any of the satisfaction scales. The mean difference between the preoperative LogMAR BCVA and the postoperative LogMAR UCVA was $0.07 \pm 0.15$ and showed a negative correlation with the uncorrected vision score $(r=-0.419, P=0.001)$. The mean difference between the pre- and postoperative LogMAR BCVA was $-0.09 \pm 0.09$.

Refraction. Surgery was aimed at the correction of myopia. Preoperatively, the mean spherical equivalent (SE) was $-12.09 \pm 4.09 \mathrm{D}$. After surgery, the mean SE was $-0.60 \pm 0.78 \mathrm{D}$. In the population, $62.4 \%$ was within $\pm 0.5 \mathrm{D}$, and $81.5 \%$ was within $\pm 1.0 \mathrm{D}$ from emmetropia, respectively. The postoperative sphere and SE showed a positive correlation with night driving $(\mathrm{r}=0.309, P=0.034$ and $\mathrm{r}=0.375, P=0.009$, respectively). The postoperative cylinder showed a positive correlation with the uncorrected vision score $(\mathrm{r}=0.417, P=0.001)$. The difference in the postoperative SE between eyes was $0.08 \pm 0.63 \mathrm{D}$ and showed a negative correlation with global satisfaction and night driving $(\mathrm{r}=-0.336, P=$ 0.009 and $\mathrm{r}=-0.351, P=0.012$ respectively). There was no correlation between night vision and the preoperative dioptric power $(\mathrm{r}=0.060, P=0.659)$ or the PIOL optical zone size ( $\mathrm{r}=-0.041, P=0.754)$.

Lens decentration. The mean \pm SD amount of decentration of the PIOL was $0.36 \pm 0.14 \mathrm{~mm}$ (range $0.14 \mathrm{~mm}$ to $0.74 \mathrm{~mm}$ ). Considering the centration of the PIOL on the center of the pupil, $86.4 \%$ was placed within $0.5 \mathrm{~mm}$, and $100 \%$ was within $0.75 \mathrm{~mm}$ from the center, respectively. The amount of PIOL decentration showed a weak positive correlation with glare $(\mathrm{r}=0.267, P=0.041)$. There was no correlation between HOAs and the amount of decentration of the PIOL.

Pupil size and pupil-IOL optical zone disparity. Mean scotopic and mesopic-low pupil sizes for all eyes were $6.2 \pm 0.79 \mathrm{~mm}$ (range, 4.6 to $7.6 \mathrm{~mm}$ ) and $5.2 \pm 0.79 \mathrm{~mm}$ (range, 3.5 to $7.2 \mathrm{~mm}$ ), respectively. The scotopic and the mesopic-low pupil size showed a positive correlation with the uncorrected vision score $(\mathrm{r}=0.273, P=0.035$ and $\mathrm{r}=0.276, P=0.033$, respectively). The scotopic 
and mesopic-low pupil-optical zone disparity showed a positive correlation with the uncorrected vision score $(\mathrm{r}=0.340, P=0.008$ and $\mathrm{r}=0.325, P=0.011$, respectively) and the corrected vision score $(r=0.362, P=0.030$ and $\mathrm{r}=0.389, P$ $=0.019$, respectively). The scotopic pupil size and the scotopic pupil-optical zone disparity showed a weak negative correlation with glare $(\mathrm{r}=-0.256, P=0.049$ and $\mathrm{r}=-0.280, P=0.030$, respectively) (Figure 2 ). There was no correlation between pupil size and night vision or night driving scores (Table 3).

Aberrations. All aberration measurements for the eye with the best UCVA and quality of vision scale scores are shown in Tables 4 and 5 . The night vision score showed a positive correlation with spherical aberration $\left(\mathrm{SA}, \mathrm{Z}_{4}{ }^{0}\right)(\mathrm{r}=0.303, P=$ 0.020). The glare score showed a negative correlation with total HO-RMS and vertical coma $(\mathrm{r}=-0.284, P=0.029 ; \mathrm{r}=-0.337, P=0.009)$ (Figure 3$)$. The night driving score showed a negative correlation with total RMS, HO-RMS and vertical coma $(\mathrm{r}=-0.337, P=0.017 ; \mathrm{r}=-0.313, P=0.027 ; \mathrm{r}=-0.297, P=0.036$, respectively) (Figure 4). The mesopic-low pupil size showed a positive correlation with vertical coma $(\mathrm{r}=0.274, P=0.036)$. The amount of PIOL decentration showed a positive correlation with horizontal coma $(\mathrm{r}=0.298, P=0.022)$. 


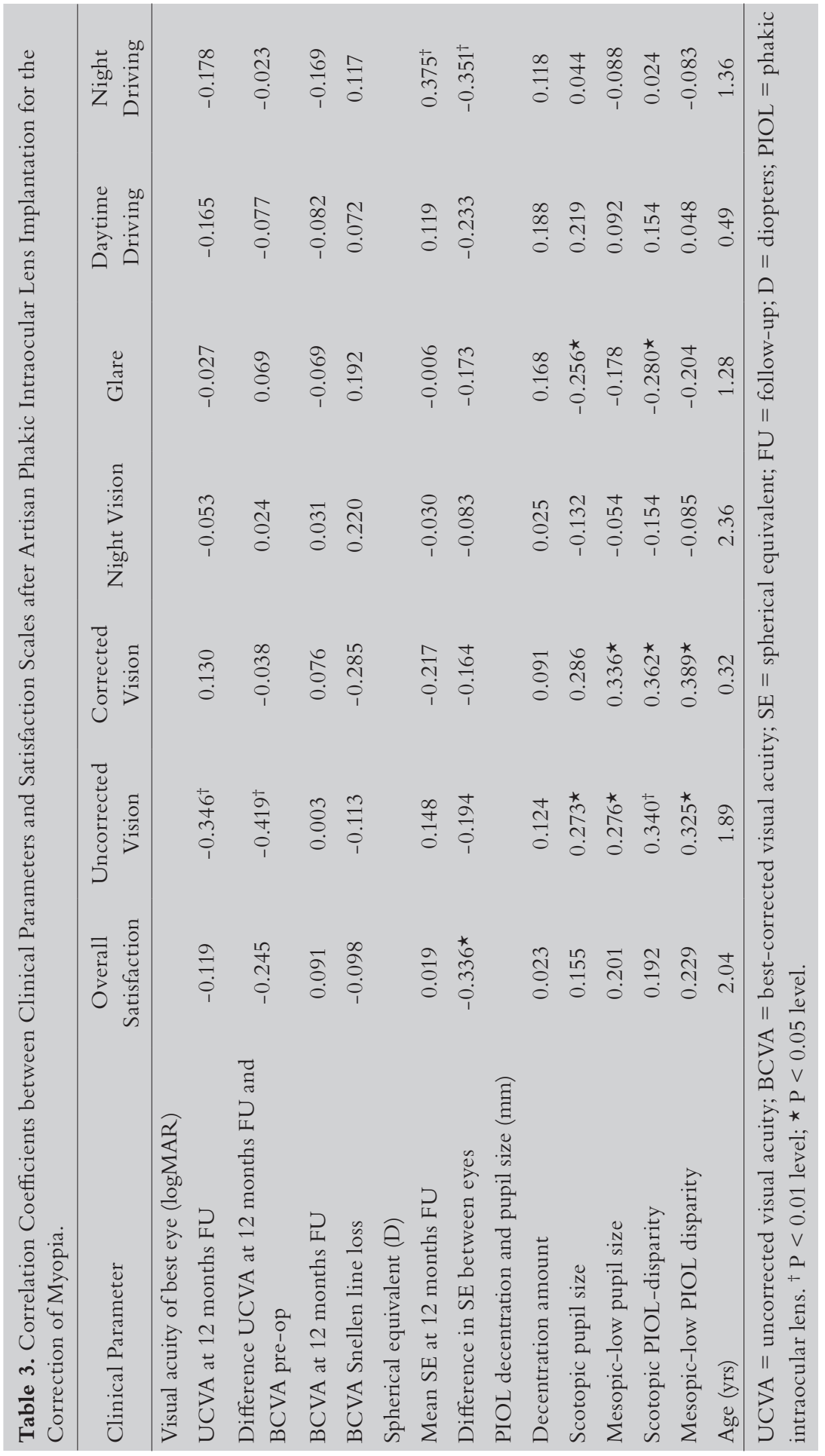


Table 4. Aberration Descriptives after Artisan Phakic Intraocular Lens Implantation for the Correction of Myopia.

\begin{tabular}{lcc}
\hline Type $(\mu \mathrm{m})$ & Mean $\pm \mathrm{SD}$ & Range \\
\hline Total RMS & $3.73 \pm 1.73$ & $1.32-7.77$ \\
Total HO-RMS & $1.05 \pm 0.52$ & $0.35-3.34$ \\
Horizontal coma $\left(\mathrm{Z}_{3}{ }^{1}\right)$ & $0.48 \pm 0.34$ & $0.01-2.30$ \\
Vertical coma $\left(\mathrm{Z}_{3}^{-1}\right)$ & $0.36 \pm 0.36$ & $0.00-2.45$ \\
Trefoil-x $\left(\mathrm{Z}_{3}{ }^{3}\right)$ & $0.29 \pm 0.19$ & $0.02-0.89$ \\
Trefoil-y $\left(\mathrm{Z}_{3}^{-3}\right)$ & $0.28 \pm 0.26$ & $0.01-0.82$ \\
$\mathrm{SA}\left(\mathrm{Z}_{4}{ }^{0}\right)$ & $0.64 \pm 0.33$ & $0.13-1.89$ \\
SD $=$ standard deviation; RMS = root mean square of the wavefront error; HO-RMS = \\
higher order root mean square of the wavefront error; SA = spherical aberration.
\end{tabular}

Table 5. Correlation Coefficients between Aberrations and Night Vision, Glare, Night Driving and Clinical Parameters after Artisan Phakic Intraocular Lens Implantation for the Correction of Myopia.

\begin{tabular}{|c|c|c|c|c|c|c|c|}
\hline & Total RMS & HO-RMS & $\mathrm{Z}_{3}{ }^{1}$ & $\mathrm{Z}_{3}^{-1}$ & $\mathrm{Z}_{3}{ }^{3}$ & $\mathrm{Z}_{3}^{-3}$ & $\mathrm{Z}_{4}{ }^{0}$ \\
\hline Night Vision & -0.208 & -0.189 & 0.003 & -0.179 & 0.067 & 0.013 & $-0.303 \star$ \\
\hline Glare & -0.180 & $-0.284^{\star}$ & -0.029 & $-0.337^{\dagger}$ & -0.060 & $-0.285^{\star}$ & -0.228 \\
\hline Night Driving & $-0.337 \star$ & $-0.313^{\star}$ & -0.211 & $-0.297 \star$ & -0.073 & -0.186 & -0.257 \\
\hline Scotopic pupil (mm) & 0.049 & 0.058 & -0.033 & 0.181 & -0.033 & 0.125 & 0.048 \\
\hline $\begin{array}{l}\text { Mesopic-low pupil } \\
(\mathrm{mm})\end{array}$ & 0.071 & 0.068 & -0.066 & $0.274 \star$ & -0.057 & 0.124 & -0.016 \\
\hline $\begin{array}{l}\text { Scotopic PIOL } \\
\text { disparity }(\mathrm{mm})\end{array}$ & 0.097 & -0.010 & -0.112 & -0.132 & 0.074 & 0.088 & -0.066 \\
\hline $\begin{array}{l}\text { Mesopic-low PIOL } \\
\text { disparity }(\mathrm{mm})\end{array}$ & 0.110 & -0.007 & -0.140 & 0.203 & 0.043 & 0.079 & -0.121 \\
\hline $\begin{array}{l}\text { Decentration PIOL } \\
(\mathrm{mm})\end{array}$ & -0.057 & 0.103 & $0.298^{\star}$ & -0.014 & 0.130 & -0.053 & 0.035 \\
\hline
\end{tabular}

RMS = root mean square; HO-RMS = higher order root mean square; $Z_{3}{ }^{1}=$ horizontal coma; $\mathrm{Z}_{3}{ }^{-1}=$ vertical coma; $\mathrm{Z}_{3}{ }^{3}=$ trefoil-x; $\mathrm{Z}_{3}{ }^{-3}=$ trefoil-y; $\mathrm{Z}_{4}{ }^{0}=$ spherical aberration; PIOL $=$ phakic intraocular lens. ${ }^{\dagger} P<0.01$ level; $\star{ }^{\star} P<0.05$. 


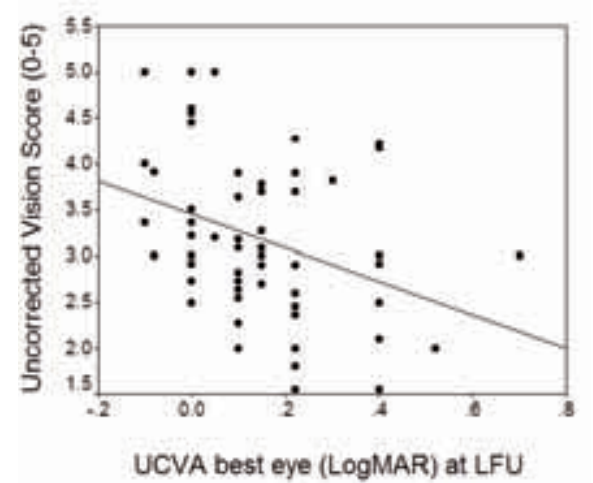

Figure 1. Uncorrected vision score versus uncorrected visual acuity (UCVA) (LogMAR) at 12 months follow-up (LFU) after Artisan Phakic Intraocular Lens Implantation;

$\mathrm{r}=-0.346, P=0.007$

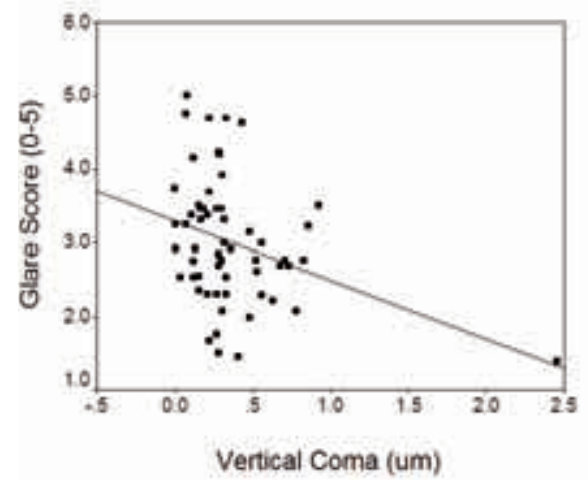

Figure 3. Glare score versus vertical coma $\left(Z_{3}{ }^{-1}\right)$ after Artisan Phakic Intraocular Lens Implantation;

$\mathrm{r}=-0.337, P=0.009$

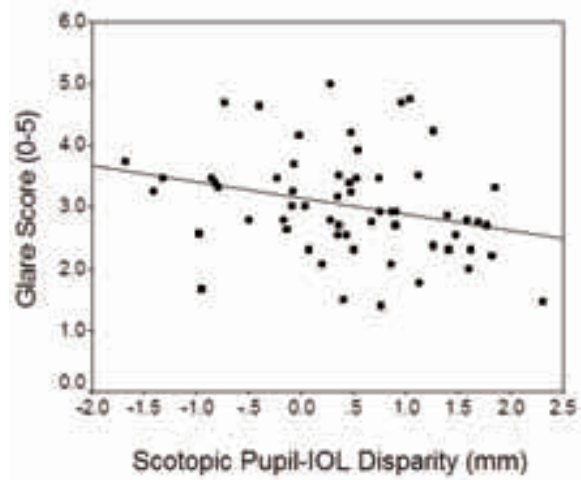

Figure 2. Glare score versus scotopic pupil-optical zone disparity after Artisan Phakic Intraocular Lens Implantation; $\mathrm{r}=-0.280, P=0.030$

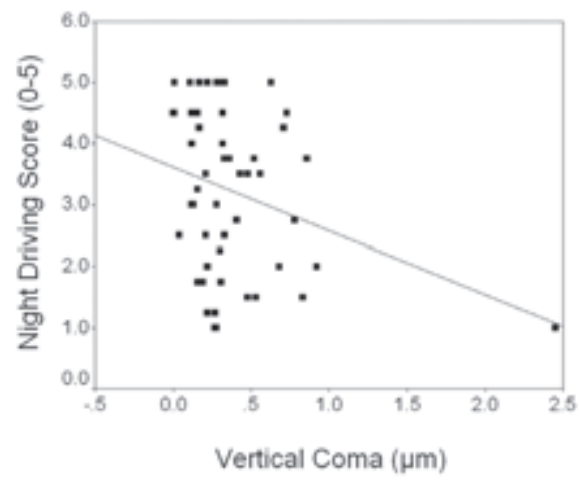

Figure 4. Night driving score versus vertical coma $\left(Z_{3}{ }^{-1}\right)$ after Artisan Phakic Intraocular Lens Implantation; $\mathrm{r}=-0.297, P=0.036$ 


\section{DISCUSSION}

In this study we analysed patient satisfaction and self-perceived quality of vision after Artisan phakic intraocular lens (PIOL) implantation for the correction of moderate to high myopia.

For this purpose, a self-administered validated questionnaire was applied, which represented the quantification of perceived quality of vision after refractive surgery. The study demonstrated that overall patient satisfaction after the Artisan PIOL implantation procedure was excellent and showed comparable results to previous PIOL studies. 9, 10,22 The results were also comparable to laser refractive surgery studies, 1, 3-5, 10, 22 which was unexpected, since it is well known that the predictability of satisfaction after refractive surgery decreases when higher levels of myopia are treated. ${ }^{3}$

Functional outcome results considering uncorrected visual acuity (UCVA), spherical equivalent (SE), and the amount of decentration of the PIOL $(86.4 \%$ had a decentration $<0.5 \mathrm{~mm}$ ) were comparable to previous reports regarding anterior chamber PIOLs for the correction of myopia (Table 6). ${ }^{10,22-25}$

Our results showed a negative correlation between the quality of vision without correction and the difference between the postoperative LogMAR UCVA and the pre-operative LogMAR BCVA. In addition, better scores for quality of vision without correction were correlated to higher postoperative UCVA values. Similar findings have also been reported in two recent patient satisfaction studies after laser in situ keratomileusis (LASIK) surgery for the correction of myopia., ${ }^{4,5}$ We report that after surgery, 23 patients (38.3\%) regularly wore glasses for distance vision. We do not believe that this finding is a suboptimal result, since most patients aimed to be less dependent on their high power spectacles, instead of being totally spectacle-free.

Secondary effects such as decreased night vision and glare remain the main downsides after refractive surgery. Our study showed that after surgery night vision decreased and glare increased in $26.7 \%$ and $44.1 \%$ of patients. Despite these complaints, overall patient satisfaction remained high with more than $90 \%$ of patients reporting to be generally satisfied after surgery. This value is consistent with several other published reports on satisfaction levels after refractive surgery techniques. ${ }^{2,4-6,11-15,24,26}$

Recently, night vision complaints (NVCs) occurring after laser refractive surgery have been correlated to the scotopic and/or mesopic-low pupil-optical zone disparity. Presumably, a wider optical zone or a transition zone would decrease the incidence of NVCs. ${ }^{27,28}$ The disparity between the pupil size and the optical zone is considered to be the main source of halos, starbursts and glare. This study demonstrated a weak negative correlation between the scotopic pupil-optical zone disparity and the glare score, but not with the "real-life" mesopic-low pupil size. Our study also showed that the scotopic and mesopic-low pupil-optical zone disparity correlated with the uncorrected and corrected vision score. These 
Table 6. Comparison of Clinical Outcome Measures Between This Study and Previous Studies on Artisan Phakic Intraocular Lens Implantation for the Correction of Myopia.

\begin{tabular}{|c|c|c|c|c|}
\hline \multirow[b]{2}{*}{ Clinical Outcome } & \multicolumn{4}{|l|}{ Studies } \\
\hline & $\begin{array}{l}\text { El Danasoury et al. } \\
2002\end{array}$ & $\begin{array}{c}\text { Maloney et al. } \\
2002\end{array}$ & $\begin{array}{l}\text { Malecaze et } \\
\text { al. } 2002\end{array}$ & Our Study \\
\hline Number of eyes & 90 & 155 & 25 & 120 \\
\hline $\begin{array}{l}\text { Mean preoperative } \\
\text { SE (D) }\end{array}$ & $-13.93 \pm 2.9$ & $-12.69 \pm 3.80$ & $-10.19 \pm 1.56$ & $-12.09 \pm 4.09$ \\
\hline FU (mos) & 12 & 6 & 12 & 12 \\
\hline UCVA $\geq 20 / 40(\%)$ & 88.4 & 85.0 & 60 & 76.6 \\
\hline $\begin{array}{l}\text { Mean SE } \pm 1.0 \mathrm{D} \\
\text { of emmetropia (\%) }\end{array}$ & 65.1 & 90.0 & 60.0 & 81.7 \\
\hline $\begin{array}{l}\text { Mean SE } \pm 0.5 \mathrm{D} \\
\text { of emmetropia (\%) }\end{array}$ & 25.6 & 48.0 & $\mathrm{n} / \mathrm{a}$ & 62.4 \\
\hline
\end{tabular}

correlations may be explained by the fact that in eyes with a larger pupil size, more light energy was directed through the corrected optical zone of the PIOL. This finding could indicate a possible beneficial consequence of larger pupils in reference to postoperative vision after refractive surgery. $4,15,29$ In addition, the Stiles-Crawford effect probably protects patients with a pupil-optical zone disparity from increased levels of glare after Artisan PIOL implantation. ${ }^{30}$ These issues emphasize the importance of standardized preoperative pupil size measurement.

The average PIOL decentration value was $0.36 \pm 0.14 \mathrm{~mm}$. In contrast to expectations, higher levels of PIOL decentration did not lead to increased glare, showing that PIOL centration on the pupil center was not a significant predictor of postoperative glare levels. This might be related to the fact that the pupillary axis is known not to coincide with the visual axis in eyes with high myopia. ${ }^{31}$ Wavefront aberrations can objectively measure the optical quality after corneal laser surgery. Several studies have reported on induced aberrations after corneal laser surgery. ${ }^{21,28,32-34}$ A recent case series demonstrated no tendency towards deterioration of the optical performance after the insertion of an Artisan lens for the treatment of high myopia. ${ }^{35}$ Our study demonstrated a correlation between the three satisfaction scales night vision, glare and night driving, and the total root mean square (RMS), higher-order RMS, vertical coma, trefoil-y and spherical aberration. Correlations were also seen between the mesopic-low pupil size and vertical coma and between the amount of PIOL decentration and horizontal coma. However, this did not lead to increased glare complaints in our patient population. These findings are most probably explained by the proposed change 
in pupil dynamics after PIOL implantation, resulting in a larger vertical than horizontal pupil diameter after pupil dilation, ${ }^{36}$ thereby increasing the amount of vertical coma and other aberrations. A limitation in our study was the lack of preoperative wavefront measurement data, which would have enabled us to objectively determine the effect of PIOL implantation on wavefront aberrations. However, the wavefront aberrometer used in this study cannot accurately measure aberrations in eyes with a myopic SE of more than $-12.0 \mathrm{D}$, while the average SE in our patient group was $-12.09 \mathrm{D}$ (range, -5.63 to $-27.25 \mathrm{D}$ ).

In conclusion, patient satisfaction after Artisan PIOL implantation for myopia is excellent, despite the occurrence of NVCs. We feel that accurate measurements of the "real-life" pupil size under dim light conditions remain vital when selecting suitable refractive surgery candidates. Future research and PIOL design modifications should aim to limit higher order aberrations and PIOL decentration effects to optimize night vision and minimize glare. Until the outcome of refractive surgery is fully predictable, patients should be educated on the potential side effects of PIOL implantation. 


\section{REFERENCES}

1. Brunette I, Gresset J, Boivin JF, et al. Functional outcome and satisfaction after photorefractive keratectomy. Part 2: survey of 690 patients. Ophthalmology 2000;107:1790-1796.

2. Hadden OB, Ring CP, Morris AT, Elder MJ. Visual, refractive, and subjective outcomes after photorefractive keratectomy for myopia of 6 to 10 diopters using the Nidek laser. J Cataract Refract Surg 1999;25:936-942.

3. Knorz MC, Wiesinger B, Liermann A, Seiberth V, Liesenhoff H. Laser in situ keratomileusis for moderate and high myopia and myopic astigmatism. Ophthalmology 1998;105:932-940.

4. Bailey MD, Mitchell GL, Dhaliwal DK, Boxer Wachler BS, Zadnik K. Patient satisfaction and visual symptoms after laser in situ keratomileusis. Ophthalmology 2003;110:1371-1378.

5. Tahzib NG, Bootsma SJ, Eggink FA, Nabar VA, Nuijts RM. Functional outcomes and patient satisfaction after laser in situ keratomileusis for correction of myopia. J Cataract Refract Surg 2005;31:1943-1951.

6. Hammond SD, Jr., Puri AK, Ambati BK. Quality of vision and patient satisfaction after LASIK. Curr Opin Ophthalmol 2004;15:328-332.

7. McGhee CN, Craig JP, Sachdev N, Weed KH, Brown AD. Functional, psychological, and satisfaction outcomes of laser in situ keratomileusis for high myopia. J Cataract Refract Surg 2000;26:497-509.

8. McDonald MB, Carr JD, Frantz JM, et al. Laser in situ keratomileusis for myopia up to -11 diopters with up to -5 diopters of astigmatism with the summit autonomous LADARVision excimer laser system. Ophthalmology 2001;108:309-316.

9. Dick HB, Aliyeva S, Tehrani M. Change in pupil size after implantation of an irisfixated toric phakic intraocular lens. J Cataract Refract Surg 2005;31:302-307.

10. El Danasoury MA, El Maghraby A, Gamali TO. Comparison of iris-fixed Artisan lens implantation with excimer laser in situ keratomileusis in correcting myopia between -9.00 and -19.50 diopters: a randomized study. Ophthalmology 2002;109:955-964.

11. Ghaith AA, Daniel J, Stulting RD, Thompson KP, Lynn M. Contrast sensitivity and glare disability after radial keratotomy and photorefractive keratectomy. Arch Ophthalmol 1998;116:12-18.

12. Hersh PS, Brint SF, Maloney RK, et al. Photorefractive keratectomy versus laser in situ keratomileusis for moderate to high myopia. A randomized prospective study. Ophthalmology 1998;105:1512-1522, discussion 1522-1513.

13. Waring GO, 3rd. Quality of vision and freedom from optical correction after refractive surgery. J Refract Surg 1997;13:213-215.

14. Schallhorn SC, Kaupp SE, Tanzer DJ, Tidwell J, Laurent J, Bourque LB. Pupil size and quality of vision after LASIK. Ophthalmology 2003;110:1606-1614.

15. Pop M, Payette Y. Risk factors for night vision complaints after LASIK for myopia. Ophthalmology 2004;111:3-10. 
16. Brunette I, Gresset J, Boivin JF, Boisjoly H, Makni H. Functional outcome and satisfaction after photorefractive keratectomy. Part 1: development and validation of a survey questionnaire. Ophthalmology 2000;107:1783-1789.

17. van der Heijde GL, Fechner PU, Worst JG. [Optical consequences of implantation of a negative intraocular lens in myopic patients]. Klin Monatsbl Augenheilkd 1988;193:99-102.

18. Kohnen T, Terzi E, Kasper T, Kohnen EM, Buhren J. Correlation of infrared pupillometers and CCD-camera imaging from aberrometry and videokeratography for determining scotopic pupil size. J Cataract Refract Surg 2004;30:2116-2123.

19. Hament WJ, Nabar VA, Nuijts RM. Repeatability and validity of Zywave aberrometer measurements. J Cataract Refract Surg 2002;28:2135-2141.

20. Mirshahi A, Buhren J, Gerhardt D, Kohnen T. In vivo and in vitro repeatability of Hartmann-Shack aberrometry. J Cataract Refract Surg 2003;29:2295-2301.

21. Porter J, MacRae S, Yoon G, Roberts C, Cox IG, Williams DR. Separate effects of the microkeratome incision and laser ablation on the eye's wave aberration. Am J Ophthalmol 2003;136:327-337.

22. Malecaze FJ, Hulin H, Bierer P, et al. A randomized paired eye comparison of two techniques for treating moderately high myopia: LASIK and artisan phakic lens. Ophthalmology 2002;109:1622-1630.

23. Budo C, Hessloehl JC, Izak M, et al. Multicenter study of the Artisan phakic intraocular lens. J Cataract Refract Surg 2000;26:1163-1171.

24. Benedetti S, Casamenti V, Marcaccio L, Brogioni C, Assetto V. Correction of myopia of 7 to 24 diopters with the Artisan phakic intraocular lens: two-year follow-up. J Refract Surg 2005;21:116-126.

25. Maloney RK, Nguyen LH, John ME. Artisan phakic intraocular lens for myopia:shortterm results of a prospective, multicenter study. Ophthalmology 2002;109:1631-1641.

26. Rajan MS, Jaycock P, O'Brart D, Nystrom HH, Marshall J. A long-term study of photorefractive keratectomy; 12-year follow-up. Ophthalmology 2004;111:1813-1824.

27. Fan-Paul NI, Li J, Miller JS, Florakis GJ. Night vision disturbances after corneal refractive surgery. Surv Ophthalmol 2002;47:533-546.

28. Boxer Wachler BS, Huynh VN, El-Shiaty AF, Goldberg D. Evaluation of corneal functional optical zone after laser in situ keratomileusis. J Cataract Refract Surg 2002;28:948-953.

29. Klyce SD. Night vision after LASIK: the pupil proclaims innocence. Ophthalmology 2004;111:1-2.

30. Atchison DA, Scott DH. The Stiles-Crawford effect and subjective measurement of aberrations. Vision Res 2002;42:1089-1102.

31. Mandell RB. Locating the corneal sighting center from videokeratography. J Refract Surg 1995;11:253-259.

32. Hiatt JA, Grant CN, Boxer Wachler BS. Establishing analysis parameters for spherical aberration after wavefront LASIK. Ophthalmology 2005;112:998-1002.

33. Mrochen M, Jankov M, Bueeler M, Seiler T. Correlation between corneal and total wavefront aberrations in myopic eyes. J Refract Surg 2003;19:104-112. 
34. Kohnen T, Buhren J, Kuhne C, Mirshahi A. Wavefront-guided LASIK with the Zyoptix 3.1 system for the correction of myopia and compound myopic astigmatism with 1-year follow-up: clinical outcome and change in higher order aberrations. Ophthalmology 2004;111:2175-2185.

35. Brunette I, Bueno JM, Harissi-Dagher M, Parent M, Podtetenev M, Hamam H. Optical quality of the eye with the Artisan phakic lens for the correction of high myopia. Optom Vis Sci 2003;80:167-174.

36. Bootsma SJ, Tahzib NG, Eggink FAGJ, Brabander de J, Nuijts RMMA. Evaluation of Pupil Dynamics after Implantation of Artisan Phakic Intraocular Lenses. J Refract Surg 2006; Forthcoming. 
hapter 5 
A long-term study of Artisan phakic intraocular lens implantation for the correction of moderate to high myopia:

10-Year Follow-Up Results

Tahzib NG, Nuijts RMMA, Wu WY, Budo CJ.

Ophthalmology. 2007 Jun;114(6):1133-42. 


\section{ABSTRACT}

Purpose: To determine the long-term performance of the Artisan phakic intraocular lens (PIOL) for the correction of myopia.

Design: A long-term (10 years) retrospective follow-up study.

Participants: Eighty-nine eyes of 49 patients who underwent Artisan PIOL implantation for the correction of myopia.

Methods: Comparisons were made between preoperative clinical data and the clinical data at 1, 6 and 10 years after surgery.

Main Outcome Measures: Refractive stability, refractive predictability, safety, efficacy, best-corrected visual acuity (BCVA), uncorrected visual acuity (UCVA), intraocular pressure, intra-operative problems, corneal endothelial cell density (ECD), corneal endothelial cell loss and glare levels were evaluated.

Results: The mean spherical equivalent (SE) after 10 years was $-0.70 \pm 1.00 \mathrm{D}$ (range, -4.00 to $2.00 \mathrm{D}$ ), with no significant change in mean SE between 1, 6, and 10 years. At 10 years, $68.8 \%$ of all eyes were within $1.0 \mathrm{D}$ of the intended correction. At 10 years, $31.2 \%(n=24)$ gained 1 or more Snellen lines of BCVA and 2.6\% $(n=2)$ lost more than 2 Snellen lines of BCVA; $93.3 \%$ reached a BCVA of 20/40 or better and $82.0 \%$ reached a UCVA of $20 / 40$ or better. The mean intraocular pressure remained stable and was $15.5 \pm$ $3.5 \mathrm{mmHg}$ (range, 7 to $25 \mathrm{mmHg}$ ) at 10 years. The mean endothelial cell loss was $-8.86 \%$ \pm 16.01 (range, -51.69 to $34.43 \%$ ) at 10 years.

Conclusion: Long-term results demonstrate that the implantation of an Artisan PIOL for the correction of moderate to high myopia is a stable, predictable and safe method when strict inclusion criteria for surgery are applied. There was no significant loss of corneal endothelial cells and no long-term glare reports. 


\section{INTRODUCTION}

To be able to evaluate the results of any corneal refractive surgical technique, it is essential to monitor the long-term refractive stability, refractive predictability, safety and efficacy of that particular procedure. Several published clinical reports have demonstrated the excellent short-term performance of the Artisan phakic intraocular lens (PIOL). ${ }^{1-10}$ When evaluating surgical results of PIOL implantations, the assessment of corneal endothelial cell loss over time is an additional important factor in determining the long-term safety.

The long-term accuracy of excimer laser refractive surgery is known to decline with higher levels of myopia. ${ }^{11-13}$ Additionally, secondary effects such as glare and halos are common downsides after excimer laser treatment for moderate to high myopia, because more corneal tissue is removed and the optical zone needs to be smaller to prevent excessively deep ablations. ${ }^{14-16}$ The surgical implantation of PIOLs offer advantages in the correction of high myopia in that they provide the best chance of maintaining the best-corrected visual acuity (BCVA). ${ }^{3,17}$ Specific concerns related to the implantation of PIOLs are the safety of the surgical procedure for the corneal endothelium, the stability of the refractive results and the long-term biocompatibility with the ocular tissue.7,10

Implantations of PIOLs have been at the center of scientific interest for the surgical correction of moderate to high myopia, for example in patients who are intolerant to contact lenses and/or spectacles. Of the three currently existing phakic lens models (iris-fixated, angle-supported and posterior chamber), we evaluated the Artisan iris-fixated convex-concave PIOL.

Since PIOLs are implanted in healthy and phakic eyes, it is required that the implanted device provides a long-term tolerance by the ocular tissues. A lack of reports on the long-term stability and predictability of these types of refractive surgery procedures remains an important issue among eye surgeons. The implantation of the lens leading to chronic stress on the corneal endothelium with a concomitant corneal endothelial cell loss is of particular concern. Short-term clinical reports have demonstrated that corneal endothelial cell loss after Artisan PIOL implantation varies from $0.7 \%$ to $2.4 \%$ after 1 year and $0.7 \%$ to $11.7 \%$ after 3 years. ${ }^{1-3,5,6,8-10}$

The purpose of this study was to assess the long-term (10-year) performance of the Artisan PIOL for the correction of moderate to severe myopia. The Artisan PIOL is a lens with a fixed optical zone of 5.0 or $6.0 \mathrm{~mm}$, depending on the dioptric power of the lens. The main outcome measures that were investigated included refractive stability, refractive predictability, safety, efficacy, BCVA, uncorrected visual acuity (UCVA), intraocular pressure, intra-operative problems and corneal endothelial cell loss over a period of 10 years. 


\section{METHODS}

\section{Patient population and study design}

Patients were originally identified and had surgery in 1991. The initial study group consisted of 177 eyes of 89 patients who had undergone surgical implantation of an Artisan PIOL for the correction of moderate to high myopia. Of the original group of 177 eyes of 89 patients, a group of 89 eyes of 49 patients were evaluated 1, 6 and 10 years after the surgical procedure. Data from the remaining 88 eyes were excluded from analyses in the study, because of differing time points of clinical evaluation.

Comparisons of pre- and postoperative clinical data were made for all eyes. Institutional Review Board approval was obtained from the Academic Hospital Maastricht.

\section{Inclusion criteria}

Included patients had a stable refraction during the previous 2 years, an anterior chamber depth of $3.0 \mathrm{~mm}$ or more; an endothelial cell density (ECD) count of 2000 cells $/ \mathrm{mm}^{2}$ or more, a normal pupil and iris configuration; no history of glaucoma, no pre-existent corneal, lenticular or retinal pathology likely to alter vision and no history of chronic or recurrent uveitis.

\section{Clinical evaluation}

Pre- and postoperatively, subjective and objective refraction was determined by measurement of the Snellen UCVA and BCVA. Slit-lamp microscopy, Goldmann applanation tonometry and fundus examination were performed. Pupil sizes were measured under mesopic conditions using the Goldmann visual field analyzer (Haag Streit, Bern, Switzerland).

\section{Endothelial cell density}

All ECD counts were performed by one independent employee. ECD counts were determined by manual counting before and after surgery using a specular microscope (Topcon SP-1000 and SP-2000P Non-Contact Specular Microscope, Topcon Corp., Tokyo, Japan). During measurements, three consecutive endothelial images were obtained. The estimated ECD for each eye was measured using the mean value of the three consecutive ECD measurements. ECD loss was defined as the decrease in cell density between the preoperative examination and the postoperative (e.g. 1, 6 and 10 year) examination, expressed as a percentage of the preoperative ECD. 
Surgical procedure

All surgical treatments were performed by one surgeon (C.B.) in a private clinic in St. Truiden, Belgium. The power of the PIOL was calculated using the Van der Heijde formula, which uses the mean corneal curvature $(\mathrm{K})$, adjusted anterior chamber depth (ACD) (= ACD - $0.8 \mathrm{~mm}$ ), and SE of the patient's spectacle correction at a $12.0 \mathrm{~mm}$ vertex. ${ }^{18}$ The Artisan iris-fixated PIOL has a convexconcave polymethyl methacrylate optic which is available with an optic of either a $6-\mathrm{mm}$ (for intraocular lens powers up to $-15.5 \mathrm{D}$ ) or $5-\mathrm{mm}$ (for intraocular lens powers from -16.0 D up to -24.0 D) (Ophtec B.V., Groningen, the Netherlands). For this study, only the Artisan myopia 5-mm optic lens (model 206) was used. The lens is $8.5 \mathrm{~mm}$ in overall length and has a vault of $0.8 \mathrm{~mm}$, and is available in powers from -5.0 to -20.0 D. Before 1997 , the lens was available in only 1.0 $\mathrm{D}$ power increments; since 1997, it has been available in $0.5 \mathrm{D}$ increments. The Artisan PIOL is positioned in the anterior chamber and held in place by fixation to the midperipheral iris stroma, creating a bridge over the optical axis.

For all cases, surgery was performed under general anaesthesia. All eyes received identical surgical treatment. A two-plane $6.3 \mathrm{~mm}$ corneoscleral incision was centered at 12-o'clock. Two paracenteses were placed at 2- and 10 o'clock and directed towards the enclavation sites. Miosis was achieved through preoperative instillation of pilocarpine (Isopto ${ }^{\circledR}$ Carpine, Alcon, Fort Worth, Texas) and a peroperative intracameral injection of acetylcholine 1.0\% (Miochol ${ }^{\circledR}$, Bournonville Pharma, The Hague, Netherlands) in order to prepare the iris for PIOL fixation, reduce the risk of lens-touch during implantation, and facilitate centration of the PIOL. A viscoelastic substance (Healon GV $^{\circledR}$, Pharmacia, Uppsala, Sweden) was inserted through the paracenteses and primary incision to maintain sufficient ACD, protect the endothelium, and facilitate adjusting the PIOL within the eye during fixation. The PIOL was introduced with a Budo forceps (Duckworth and Kent, Ltd, Baldock Herts, England). After subtle rotation of the PIOL, it was fixated in the horizontal axis with the use of a disposable enclavation needle (Ophtec BV, Groningen, Netherlands). A slit iridotomy was performed at 12 o'clock to avoid pupillary block glaucoma. The viscoelastic substance was exchanged for balanced salt solution (Alcon, Fort Worth, Texas). The wound was sutured with 3 to 5 interrupted 10-0 nylon sutures (Alcon, Fort Worth, Texas). Postoperatively, topical tobramycin $0.3 \%$ combined with dexamethasone 0.1\% (Tobradex ${ }^{\circledR}$, Alcon, Couvreur, Belgium) and ketorolactrometamol 0.5\% $\left(\right.$ Acular $^{\circledR}$, Westport Co., Mayo, Ireland) were used four times daily for 3 weeks in a tapered schedule and three times daily for 1 week, respectively.

\section{Glare}

Glare levels were assessed using a questionnaire that has been previously used for the evaluation of patient satisfaction after refractive surgery. ${ }^{16,18-20}$ The instrument 
has proven to be reliable by a high level of internal consistency with Cronbach's alpha coefficients superior or equal to 0.83 . Glare scale scores ranged from 1 (high glare levels) to 5 (no glare).

\section{Statistical analysis}

BCVA in LogMAR was used for data reports, meaning, the lower the value the better the vision. Statistical analysis and comparisons between preoperative and postoperative data and between individual postoperative years were performed by paired students t-tests $(P<0.05$ being significant) (SPSS for Windows, SPSS Inc., Chicago, IL). All values in the text are mean \pm standard deviation (SD). Data from clinical evaluations at postoperative years 1, 6 and 10 years were used for analysis.

A linear decrease of $0.6 \%$ physiologic loss per year was applied for the preoperative ECD value, after which paired t-tests were used to compare postoperative ECD values with the preoperative ECD values.

\section{RESULTS}

\section{Patient population}

Thirty-four patients were female and 15 were male. The mean preoperative age for all patients was $38.3 \pm 10.5$ years (range, 19 to 61 years). Population characteristics are listed in Table 1.

The baseline parameters for all 89 eyes were a mean sphere of $-9.78 \pm 4.43 \mathrm{D}$ (range, -3.50 to $-25.00 \mathrm{D}$ ), a mean refractive cylinder of $-1.26 \pm 1.40 \mathrm{D}$ (range -6.75 to $0 \mathrm{D}$ ) and a mean baseline SE of $-10.36 \pm 4.69 \mathrm{D}$ (range, -3.75 to -25.25 D).

The mean baseline LogMAR BCVA was $0.16 \pm 0.23$ (range, 0 to 1 ). The mean anterior chamber depth was $3.30 \pm 0.28 \mathrm{~mm}$ (range, 3.00 to $4.20 \mathrm{~mm}$ ) and the mean intraocular pressure was $14.7 \pm 2.8 \mathrm{mmHg}$ (range, 8.0 to $19.0 \mathrm{mmHg}$ ). The mean baseline ECD was $2817 \pm 359$ cells $/ \mathrm{mm}^{2}$ (range, 2100 to 3900 cells/ $\mathrm{mm}^{2}$ ). The mean power of the implanted PIOL was $-12.60 \pm 4.20 \mathrm{D}$ (range, -7.0 to $-20.0 \mathrm{D}$ ). The preoperative pupil size was $4.5 \pm 0.9 \mathrm{~mm}$ (range, 3.0 to $7.0 \mathrm{~mm}$ ), with a pupil size larger than $5.0 \mathrm{~mm}$ in $9.5 \%$ of eyes.

\section{Refractive stability}

After 1,6 and 10 years, the mean SE was $-0.70 \pm 0.97 \mathrm{D}$ (range, -4.88 to $1.75 \mathrm{D}$ ), $-0.71 \pm 0.99 \mathrm{D}$ (range, -4.50 to $2.00 \mathrm{D}$ ) and $-0.70 \pm 1.00 \mathrm{D}$ (range, -4.00 to 2.00 $D)$, respectively. No significant change in mean SE was found between the 1, 6, and 10 years after surgery $(P=0.94$ and $P=0.71)$ (Table 2) (Fig 1). 
Table 1. Summary of population characteristics and preoperative data.

\begin{tabular}{|c|c|c|c|}
\hline Variable & Mean \pm SD & Rang & \\
\hline Mean patient age (yrs) & $38.35 \pm 10.50$ & $19-61$ & \\
\hline Number of females & 34 & & \\
\hline Number of eyes & 89 & & \\
\hline Right eyes & 44 & & \\
\hline Left eyes & 45 & & \\
\hline Sphere (D) & $-9.78 \pm 4.43$ & -3.50 to & -25.00 \\
\hline Cylinder (D) & $-1.26 \pm 1.40$ & -6.75 to & 0.00 \\
\hline $\mathrm{SE}(\mathrm{D})$ & $-10.36 \pm 4.69$ & -3.75 to & -25.25 \\
\hline $\mathrm{ACD}(\mathrm{mm})$ & $3.30 \pm 0.28$ & 3.00 to & 4.20 \\
\hline $\mathrm{IOP}(\mathrm{mmHg})$ & $14.7 \pm 2.8$ & 8.0 to & 19.0 \\
\hline $\mathrm{ECD}\left(\right.$ cells $\left./ \mathrm{mm}^{2}\right)$ & $2817 \pm 359$ & 2100 to & 3900 \\
\hline Implanted lens power (D) & $-12.60 \pm 4.20$ & -7.00 to & -20.0 \\
\hline
\end{tabular}

Table 2. Mean \pm SD spherical equivalent before and after Artisan phakic intraocular lens implantation for the correction of moderate to high myopia.

\begin{tabular}{|c|c|c|c|c|}
\hline & Mean $\pm \mathrm{SD}$ & Number of eyes & Range & $P$ value ${ }^{\star}$ \\
\hline Before surgery & $-10.37 \pm 4.67$ & 89 & -25.25 to -3.75 & \\
\hline \multicolumn{5}{|l|}{ After surgery } \\
\hline 1 year & $-0.70 \pm 0.97$ & 89 & -4.88 to 1.75 & - \\
\hline 6 years & $-0.71 \pm 0.99$ & 89 & -4.50 to 2.0 & 0.94 \\
\hline 10 years & $-0.70 \pm 1.00$ & 89 & -4.00 to 2.0 & 0.71 \\
\hline
\end{tabular}

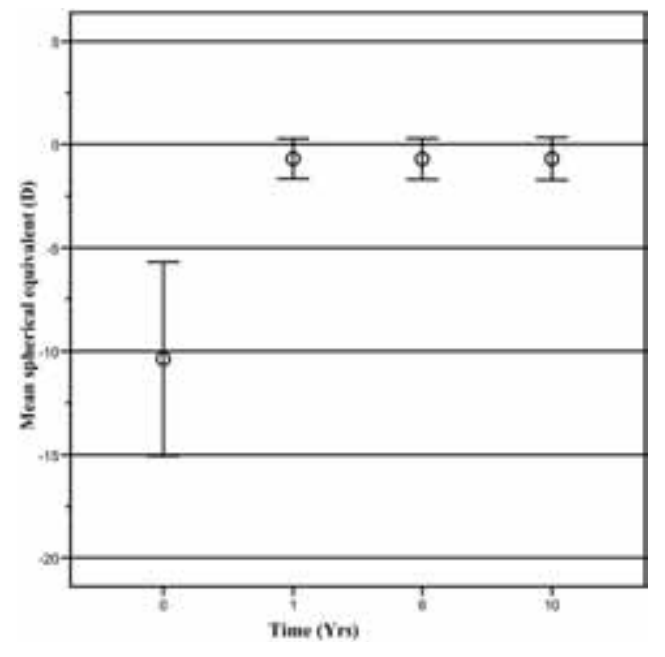

Figure 1. Graph demonstrating the stability of postoperative spherical equivalent after Artisan phakic intraocular lens implantation for the correction of moderate to high myopia. Mean \pm standard deviation spherical equivalent before implantation (-10.36 $\pm 4.69, \mathrm{n}=89)$ and after 1 year $(-0.70$ $\pm 0.97, \mathrm{n}=89), 6$ years $(-0.71 \pm 0.99$, $\mathrm{n}=89)$ and 10 years $(-0.70 \pm 1.02$, $\mathrm{n}=69)$ are demonstrated $(P>0.05)$. $\mathrm{D}=$ diopters 
Table 3. Overview of refractive predictability after Artisan phakic intraocular lens implantation for the correction of moderate to high myopia.

$\begin{array}{lll}\text { Year } 1 & \text { Year } 6 & \text { Year } 10\end{array}$

Refractive Predictability Number of eyes (\%) Number of eyes (\%) Number of eyes (\%)

\begin{tabular}{llll} 
& $(\mathrm{n}=89)$ & $(\mathrm{n}=89)$ & $(\mathrm{n}=89)$ \\
\hline $\pm 0.5 \mathrm{D}$ & $38.3(32)$ & $50.5(45)$ & $43.8(39)$ \\
$\pm 1.0 \mathrm{D}$ & $74.2(66)$ & $65.1(58)$ & $68.8(61)$ \\
$\pm 2.0 \mathrm{D}$ & $94.4(84)$ & $93.3(83)$ & $93.3(83)$ \\
\hline $\mathrm{D}=$ diopter. & &
\end{tabular}

$\mathrm{D}=$ diopter.

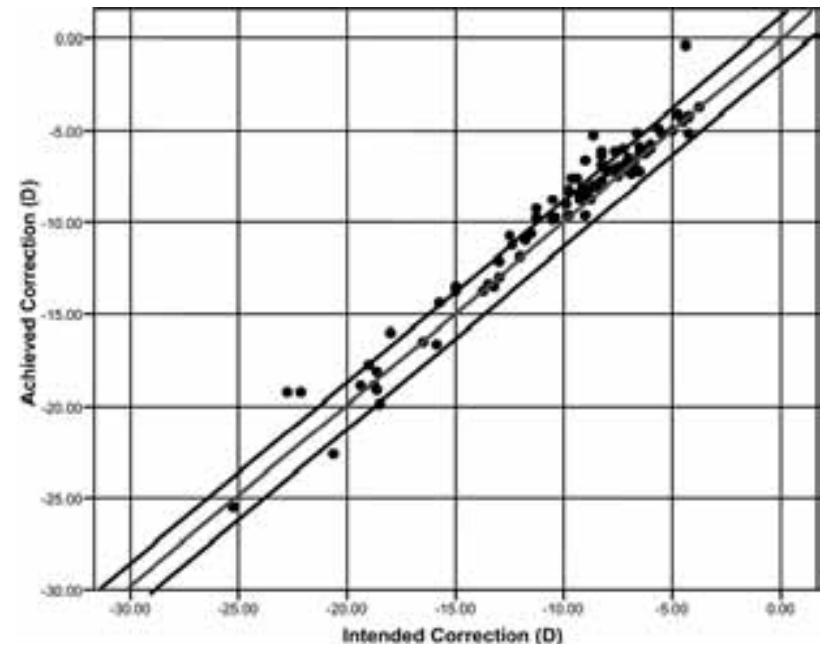

Figure 2. Scatterplot demonstrating the refractive predictability of the spherical equivalent 10 years after Artisan phakic intraocular lens implantation for the correction of moderate to high myopia; $65.2 \%(\mathrm{n}=45)$ were within \pm 1.0 diopter $(\mathrm{D})$ of the desired refraction. The red line is the line where the intended correction equals the achieved correction.

\section{Refractive predictability-spherical equivalent}

The deviation of the achieved SE correction from the calculated (intended) refractive SE correction was calculated. After 1, 6 and 10 years, 38.3\% $(n=34)$, $50.5 \%(n=45)$ and $43.8 \%(n=39)$ of eyes were within $\pm 0.5 \mathrm{D}$ of the desired refraction, respectively. After 1, 6 and 10 years, $74.2 \%(n=66), 65.1 \%(n=58)$ and $68.8 \%(\mathrm{n}=61)$ of eyes were within $\pm 1.0 \mathrm{D}$ of the desired refraction, respectively. After 1, 6 and 10 years, 94.4\% $(\mathrm{n}=84), 93.3 \%(\mathrm{n}=83)$ and $93.3 \%(\mathrm{n}=83)$ of eyes were within $\pm 2.0 \mathrm{D}$ of the desired refraction, respectively (Table 3 ) (Fig 2). 
Table 4. Overview of refractive cylinder values after Artisan phakic intraocular lens implantation for the correction of moderate to high myopia.

\begin{tabular}{lccc}
\hline & Mean \pm SD & Range & Number of eyes \\
\hline Before surgery & $-1.26 \pm 1.40$ & -6.75 to 0.0 & 89 \\
After surgery & & & \\
Year 1 & $-1.02 \pm 0.85$ & -4.0 to 0.0 & 89 \\
Year 6 & $-1.0 \pm 0.90$ & -4.0 to 0.0 & 89 \\
Year 10 & $-0.94 \pm 0.79$ & -4.0 to 0.0 & 89 \\
\hline SD = standard deviation. & & &
\end{tabular}

\section{Refractive predictability-astigmatic correction}

After 1,6 and 10 years, the mean refractive cylinder was $-1.02 \pm 0.85 \mathrm{D}$ (range, -4.00 to $0 \mathrm{D}, \mathrm{n}=89),-1.00 \pm 0.90 \mathrm{D}$ (range, -4.00 to $0 \mathrm{D}, \mathrm{n}=89$ ) and $-0.94 \pm 0.79$ $\mathrm{D}$ (range, -4.00 to $0 \mathrm{D}, \mathrm{n}=89$ ), respectively. A postoperative refractive cylinder of more than $1.5 \mathrm{D}$ was found in $15.7 \%(\mathrm{n}=14), 20.2 \%(\mathrm{n}=18)$ and $12.4 \%(\mathrm{n}=11)$ after 1,6 and 10 years, respectively (Table 4 ).

Safety

The mean preoperative LogMAR BCVA for all 89 eyes was $0.16 \pm 0.23$ (range, 0 to 1). After 1, 6 and 10 years, the mean LogMAR BCVA was $0.07 \pm 0.09$ (range, -0.08 to 0.30 ), $0.12 \pm 0.17$ (range, -0.08 to 1.30 ) and $0.12 \pm 0.21$ (range, -0.08 to 1.30 ), respectively. A BCVA of $20 / 40$ or better was found in $100 \%, 96.6 \%$ and $93.3 \%$ of eyes after 1,6 and 10 years, respectively. A BCVA of 20/20 or better was found in $70.8 \%, 50.6 \%$ and $52.8 \%$ of eyes after 1,6 and 10 years, respectively. After 1,6 and 10 years, $40.3 \%(n=31), 26.0 \%(n=20)$ and $31.2 \%(n=24)$ gained 1 or more Snellen lines of BCVA, respectively. After 1,6 and 10 years, $1.3 \%(n=1)$, $2.6 \%(n=2)$ and $2.6 \%(n=2)$ of eyes lost more than 2 Snellen lines of BCVA, respectively (Fig. 3). The safety index (meaning, the ratio of the mean postoperative BCVA to the mean preoperative BCVA) was 1.12, 1.10 and 1.10 after 1, 6 and 10 years, respectively.

\section{Efficacy}

After 1, 6 and 10 years, the mean LogMAR UCVA for all 89 eyes was $0.16 \pm$ 0.16 (range, -0.08 to 0.60 ), $0.24 \pm 0.23$ (range, 0 to 1.30 ) and $0.27 \pm 0.29$ (range, -0.08 to 1.30 ), respectively. A UCVA of $20 / 40$ or better was found in $86.5 \%$, $78.7 \%$ and $82.0 \%$ of eyes after 1,6 and 10 years, respectively. The efficacy index (meaning, the mean post-operative UCVA to mean pre-operative BCVA) was $0.96,0.83$ and 0.80 after 1,6 and 10 years, respectively. 


\section{Intraocular pressure}

The mean preoperative intraocular pressure for all 89 eyes was $14.7 \pm 2.8 \mathrm{mmHg}$ (range, 8 to $19 \mathrm{mmHg}$ ) and changed to $15.3 \pm 3.3 \mathrm{mmHg}$ (range, 9 to $26 \mathrm{mmHg}$ ), $15.6 \pm 3.8 \mathrm{mmHg}$ (range, 9 to $24 \mathrm{mmHg}$ ) and $15.5 \pm 3.5 \mathrm{mmHg}$ (range, 7 to 25 $\mathrm{mmHg}$ ) at 1,6 and 10 years after surgery.

\section{Endothelial cell density and endothelial cell loss}

After 1, 6 and 10 years, the mean \pm SD postoperative ECD was $2928 \pm 351$ cells/ $\mathrm{mm}^{2}$ (range, 2200 to 3900 cells $/ \mathrm{mm}^{2}$ ) ( $\left.\mathrm{n}=87\right), 2734 \pm 360$ cells $/ \mathrm{mm}^{2}$ (range, 2163 to 4500 cells $\left./ \mathrm{mm}^{2}\right)(\mathrm{n}=89)$ and $2800 \pm 292$ cells $/ \mathrm{mm}^{2}$ (range, 1849 to 3850 cells $\left./ \mathrm{mm}^{2}\right)(\mathrm{n}=89)$, respectively (Fig 4$)$. In order to compare preoperative values with postoperative values, we assumed a linear decrease of $0.6 \%$ physiologic loss per year for the preoperative value. After this adjustment, we found a mean decrease of $-9.39 \% \pm 18.56$ (range, -57.47 to $17.36 \%)(P=0.002),-3.26 \% \pm$ 18.96 (range, -72.89 to $27.62 \%)(P=0.494)$ and $-8.86 \% \pm 16.01$ (range, -51.69 to $34.43 \%)(P=0.001)$ at 1,6 and 10 years follow-up, respectively (Tables 5 and 6 ). For the relative standard deviation we found a within-subjects variation of $4 \%$. The coefficient of repeatability was 344. ${ }^{21-23}$ No significant correlation was found between the preoperative anterior chamber depth and endothelial cell changes after 10 years $(\mathrm{r}=-0.050, P=0.747$, respectively).

Intra-operative problems and adverse events

There were no intra-operative problems. Throughout all follow-up years, a total of 5 eyes of 3 patients demonstrated a loss of more than 2 Snellen lines of BCVA. For follow-up year $1(n=1)$, the loss was caused by the development of a myopic maculopathy. For follow-up years $6(n=2)$ and year $10(n=2)$ the loss in Snellen lines was due to the development of a corneal guttata dystrophy and due to a visually significant cataract and were the same eyes in both years.

\section{Glare}

After 10 years follow-up, the scores for three optical side effects for all 49 patients were assessed. The mean score for perception of stars around lights, distortion of details and double outline of images were $4.49 \pm 0.65,4.69 \pm$, 0.59, $4.69 \pm 0.62$, respectively (Table 7 ).

\section{Secondary surgical intervention}

To correct a significant postoperative undercorrection, 1 eye underwent an uneventful additional excimer photorefractive keratectomy procedure 4 months 
Table 5. Mean \pm SD endothelial cell density counts before and after Artisan phakic intraocular lens implantation for the correction of moderate to high myopia.

\begin{tabular}{|c|c|c|c|c|c|}
\hline & $\begin{array}{l}\text { Number } \\
\text { of eyes }\end{array}$ & $\begin{array}{c}\mathrm{ECD} \pm \mathrm{SD} \text { (range) } \\
\text { in cells } / \mathrm{mm}^{2}\end{array}$ & Range & $\begin{array}{c}\text { ECD loss } \pm \\
\text { SD }(\%)\end{array}$ & $\mathrm{P}$ value \\
\hline Before surgery & 89 & $2817 \pm 359$ & $2100-3900$ & & \\
\hline \multicolumn{6}{|l|}{ After surgery } \\
\hline 1 years & 89 & $2928 \pm 351$ & $2200-3900$ & $-9.39 \pm 18.56$ & 0.002 \\
\hline 6 years & 89 & $2734 \pm 360$ & $2163-4500$ & $-3.26 \pm 18.96$ & 0.494 \\
\hline 10 years & 89 & $2800 \pm 292$ & $1849-3850$ & $-8.86 \pm 16.01$ & 0.001 \\
\hline
\end{tabular}

Table 6. Comparison between previous studies and our study.

\begin{tabular}{|c|c|c|c|c|c|}
\hline & Studies & & & & \\
\hline & $\begin{array}{l}\text { Menezo } \\
\text { et al. }\end{array}$ & $\begin{array}{l}\text { Budo } \\
\text { et al. }\end{array}$ & $\begin{array}{c}\text { El Danasoury } \\
\text { et al. }\end{array}$ & $\begin{array}{l}\text { Pop } \\
\text { et al. }\end{array}$ & Our study \\
\hline Number of eyes & 111 & 518 & 43 & 765 & 89 \\
\hline FU (mos) & $6-48$ & $6-36$ & 12 & $6-24$ & $12-144$ \\
\hline $\begin{array}{l}\text { Mean patient } \\
\text { age (yrs) }\end{array}$ & 34.9 & 36.4 & N/A & N/A & 38.3 \\
\hline Lens power (D) & -8.0 to -20.0 & -5.0 to -20.0 & -9.0 to -19.0 & -5.0 to -24.0 & -7.0 to -20.0 \\
\hline ECD change (\%) & & & & & \\
\hline - 1 year FU & $6.59 \pm 2.93$ & $2.4 \pm 1.0$ & $0.7 \pm 1.1$ & $-0.87 \pm 16.35$ & $-9.39 \pm 18.56$ \\
\hline-3 years FU & $11.68 \pm 4.18$ & $0.7 \pm 1.0$ & N/A & N/A & $-8.86 \pm 16.01^{\star}$ \\
\hline
\end{tabular}

Table 7. Glare scores 10 years after Artisan phakic intraocular lens implantation for the correction of moderate to high myopia $(n=49)$.

\begin{tabular}{lcc}
\hline & Mean $\pm \mathrm{SD} \star$ & Range \\
\hline Perception of stars around lights & $4.49 \pm 0.65$ & $3-5$ \\
Distortion of details & $4.69 \pm 0.59$ & $3-5$ \\
Double outline of images & $4.69 \pm 0.62$ & $3-5$ \\
\hline
\end{tabular}

*Scores 0-5 (0 meaning high glare levels, 5 meaning no glare).

after the surgical implantation. Due to a visually significant age-related cataract which developed 6 years after surgery, 2 eyes underwent explantation of the Artisan PIOL with subsequent phaco-emulsification and the implantation of a posterior chamber intraocular lens. 


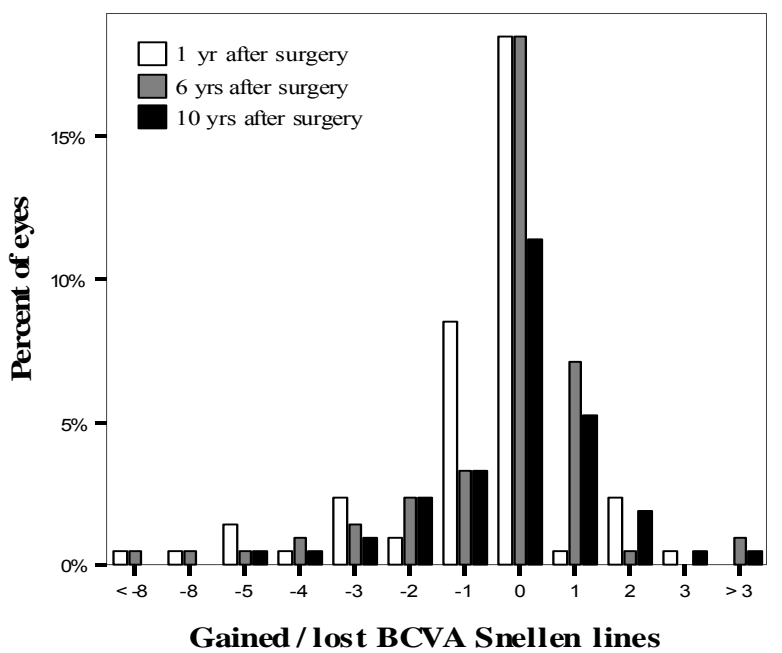

Figure 3. Bar graph demonstrating the lost and gained Snellen lines of best-corrected visual acuity (BCVA) after Artisan phakic intraocular lens implantation for the correction of moderate to high myopia. After 1, 6, and 10 years, 1.3\% $(\mathrm{n}=1), 2.6 \%(\mathrm{n}=2)$, and $3.6 \%(n=2)$ of eyes lost more than 2 Snellen lines of BCVA, respectively.

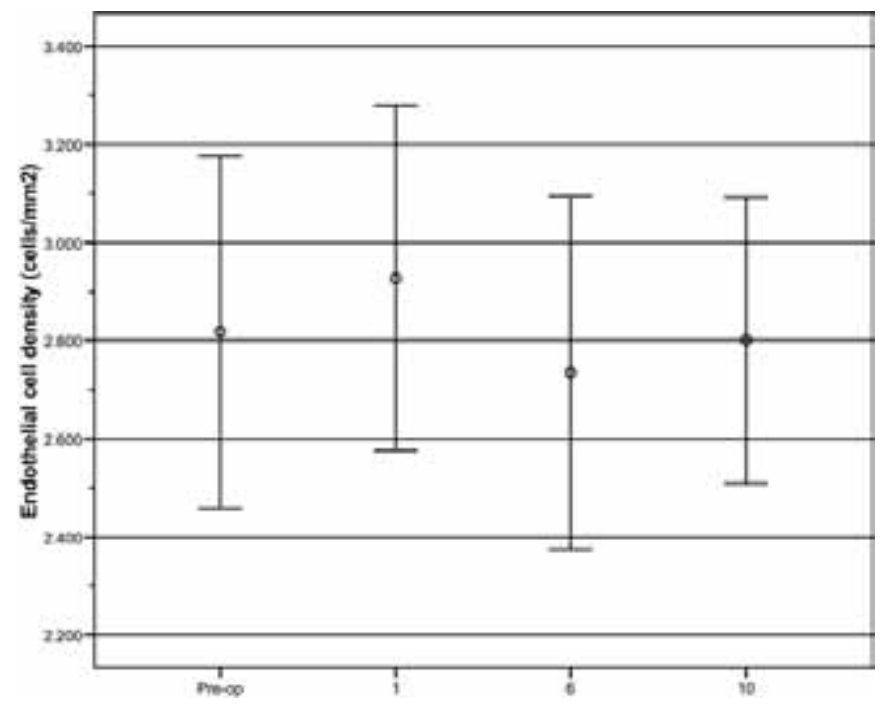

Figure 4. Graph demonstrating the mean \pm standard deviation endothelial cell density before Artisan phakic intraocular lens implantation for the correction of moderate to high myopia (2817 \pm $359, \mathrm{n}=89)$ and after 1 year $(2928 \pm 351, \mathrm{n}=89), 6$ years $(2734 \pm$ $360, \mathrm{n}=89)$ and 10 years $(2776 \pm 321, \mathrm{n}=69)$. 


\section{DISCUSSION}

The purpose of this retrospective study was to evaluate the long-term (10 year) refractive stability, refractive predictability, safety and efficacy of the Artisan phakic intraocular lens (PIOL) for the correction of moderate to high myopia and to monitor changes in corneal endothelial cell density (ECD) over time. A potential drawback of long-term studies in the field of refractive surgery is the variation in follow-up time. In our study, out of the 177 eyes of 89 patients who initially had undergone Artisan PIOL implantation, we were able to include 89 eyes of 49 patients in the study, in order to perform a paired comparative analysis between the individual follow-up years 1, 6 and 10. Data from the excluded 88 eyes were measured at different time points, and therefore not suitable for the intended comparative analysis. However, none of these eyes had lost 2 or more lines of BCVA at their last follow-up visit.

\section{Long-term refractive stability}

The short-term results of Artisan PIOL implantation have been demonstrated in several clinical reports with a follow-up time of up to 4 years., 3-7, 9, 10, 24 These reports demonstrate that stabilisation of the postoperative refraction occurs within the first few years after surgery with more than $90 \%$ of eyes that achieve a refraction within 1 diopter (D) of the intended correction and a high safety index.

The long-term data demonstrated in this study showed comparable results to the above-mentioned short-term studies on refractive stability. Ten years after Artisan PIOL implantation for the correction of moderate to high myopia, the mean \pm standard deviation (SD) spherical equivalent (SE) was $-0.70 \pm 1.00$ $\mathrm{D}$ (range, -4.00 to $2.00 \mathrm{D}$ ) and remained stable over time. This finding is in accordance with the short-term literature, which demonstrated stabilisation of the postoperative refraction within the first few years after surgery (see above). The mean SE values of $-0.7 \mathrm{D}$ after 1,6 and 10 years indicate a slight average undercorrection. The SE was aimed at slight myopia, since the lens was available in only 1.0 D power increments before 1997 (since 1997, the lens has been available in $0.5 \mathrm{D}$ increments) and care was taken to avoid a postoperative hyperopic overcorrection that certainly would decrease patient satisfaction in our highly myopic group of patients. In addition, we believe that a mean postoperative SE of $-0.7 \mathrm{D}$ in this highly myopic group with a preoperative SE of -10.36 is an acceptable result.

At 10 years postoperative, $65.2 \%$ and $92.8 \%$ of eyes were within $\pm 1.0 \mathrm{D}$ and \pm 2.0 $\mathrm{D}$ of the desired refraction with an excellent stability of the postoperative refractive cylinder; the mean $\pm \mathrm{SD}$ refractive cylinder being $-0.99 \pm 0.81 \mathrm{D}$ (range, -4.00 to $0 \mathrm{D}$ ) at 10 years. 
Visual outcome and visual complications

Short-term data showed that after Artisan PIOL implantation, over $85 \%$ of eyes demonstrated a best-corrected visual acuity (BCVA) of 20/40 or better and more than $60 \%$ of eyes gained 2 or more Snellen lines of BCVA. 1, 3-7, 9, 10, 24

Our long-term data show great similarity to the short-term data. After 10 years, patients reached a BCVA of $20 / 40$ or better in $92.5 \%$ of eyes and a UCVA of $20 / 40$ or better in $79.7 \%$ of eyes. With respect to safety, we showed that after 10 years, 3.6\% $(n=2)$ of eyes lost more than 2 Snellen lines of BCVA. Throughout all follow-up years, 5 eyes in total demonstrated a loss of more than 2 Snellen lines of BCVA. For year $1(n=1)$, the loss was caused by the development of a myopic maculopathy. For follow-up year $6(n=2)$ and $10(n=2)$, the loss in one eye of the same patient was due to the development of a corneal guttata dystrophy without preexistent signs of corneal guttata or a low endothelial cell count and in the eye of a another patient by a visually significant cataract. We believe that the loss of visual acuity was not related to the implantation of the PIOL but to the nature of myopic eye disease and earlier development of cataract in myopia. In the eye with cornea guttata it is unclear whether the cornea guttata had developed in the 6 years after the surgical procedure, or whether they were actually present at the time of patient inclusion which may have escaped diagnosis. Endothelial cell counts of greater than 2000 cells $/ \mathrm{mm}^{2}$ may be possible in patients with cornea guttata, due to the variations in regional endothelial cell density. ${ }^{25}$

From 1 to 10 years after surgery there was a slight decrease in the safety index and a larger decrease in the efficacy index of the Artisan procedure. After 10 years we found a safety index of 1.10 as compared to 1.12 at one year. The efficacy index decreased from 0.96 at one year to 0.80 after 10 years. We believe that this decrease is not related to the surgical procedure, but to the development of ageand high myopia related changes, like earlier development of lens opacities and maculopathy in this group of highly myopic patients whose average patient age after 10 years was 48.3 years., ${ }^{1,26-28}$. It can be expected that a sample size of about 100 cases can detect unanticipated severe adverse events (SAE) to occur about

$3 \%$ of the time. Our study sample demonstrated unanticipated SAE to occur at a rate of less than $5 \%$.

Long-term endothelial cell loss

Several short-term studies evaluated corneal ECD after Artisan PIOL implantation (Table 6). ${ }^{1,3-10,24,29}$ In 1998, Menezo et $\mathrm{al}^{9}$ showed data of 111 eyes with an Artisan PIOL with subsequent ECD loss of $11.7 \%$ at 3 years follow-up. In 2000, Budo et $\mathrm{al}^{1}$ reported 3 -year follow-up data of 518 patients which demonstrated a relatively low amount of ECD loss and stabilization over time (2.4\% after 1 year and $0.7 \%$ after 3 years). In 2004, Pop et a $1^{10}$ reported data which did not show any statistically significant postoperative endothelial cell loss for up to 2 years after 
Artisan PIOL implantation. No strong evidence can be found in the literature for concerns on the long-term safety of the current Artisan PIOL design. In 2000, an experimental study used scanning electron microscopy to analyse the surface quality of the Artisan lens. ${ }^{30}$ The study stated that the surface quality of this lens is excellent and that no contraindications related to surface quality could be found for the implantation of these lenses into phakic eyes. In addition, reports that have studied changes in ECD in healthy emmetropic eyes, demonstrate a correlation between patient age and ECD. With age, the number of cells decreases, with a physiologic rate of $0.6 \%$ per year after age $18 .{ }^{31}$ This means that after 10 years, a loss of about $6 \%$ could be found. In the present study, however, we could not find an endothelial cell loss of this magnitude. Our data demonstrated that there was no long-term corneal endothelial cell loss over time with a relative gain in ECD after year 1 (gain of 8.73\% \pm 18.45 ) and year 10 (gain of $3.62 \% \pm 16.97$ ) follow-up. No correlation was found between endothelial cell loss at 10 years and the preoperative anterior chamber depth, which supports the hypothesis that an anterior chamber depth of at least $3.0 \mathrm{~mm}$ is an adequate safety measure for the implantation of the Artisan PIOL. ${ }^{10}$ Previous studies have also attempted to explain the gain in ECD after Artisan PIOL implantation, among which a large variation in cell density measurements and small sample sizes which enabled the large variations. ${ }^{4,5}$ Specular microscopy measurements have been reported to be reproducible within $7 \%$, of which approximately one third is the result of the precision of the technique and the remaining two thirds is the result of the variance of the ECD population within each eye. ${ }^{10,31,32}$ Another report stated that ECD assessment may be considered less valid when evaluating corneal endothelial cell loss caused by a surgical technique. ${ }^{33}$ In the present study, ECD was measured with the Topcon 1000 specular microscope until 2002, after which measurements were taken with the Topcon 2000-P. The Topcon 1000 has been mentioned in several studies ${ }^{33-36}$, although no studies have compared this specular microscope to the newer Topcon 2000-P. A small comparative study in our department showed a high correlation for endothelial cell density between the two microscopes (unpublished data). Therefore, we do not expect that the switch in these instruments significantly contributed to a bias in ECD measurements.

Another explanation for a relative gain in ECD after implantation could be that the recovery capability of the corneal endothelium after intraocular surgery might be higher than previously assumed. A recent report by Whikehart et al. ${ }^{37}$ suggested that cells in the corneal endothelium might be renewed by stem cells located in a niche at the posterior limbus and that increased cell renewal may occur after mechanical trauma, such as intraocular surgery. Data reported by Konomi et al. ${ }^{38}$ indicated that both central and peripheral corneal endothelial cells are capable of dividing and that age had a greater influence on proliferative capacity than relative position of the cells. Data by Amann et al. ${ }^{25}$ demonstrated that the ECD in the peripheral cornea is significantly higher than in the central cornea, which plays an important role in the wound healing response of the corneal endothe- 
lium after PIOL implantation, since the peripheral cornea provides a physiologic reserve for endothelial cells. Published data of a clinical study using a different type of PIOL (the Implantable Contact Lens) suggested that corneal endothelial cell loss between the first and third postoperative years is explained by prolonged corneal ECD remodeling following the surgical procedure rather than ongoing cell loss. ${ }^{39}$

Finally, a trend toward improvement and recovery of the corneal endothelial cell morphology after discontinuation of contact lens wear has been previously reported ${ }^{40}$, including an improvement in endothelial morphology parameters after photorefractive keratectomy $(\mathrm{PRK})^{41,42}$ and laser in situ keratomileusis (LASIK $^{43,44}$. This improvement was attributed to the discontinuation of contact lens and/or switching to spectacle-wear. This might be another explanation for the relative gain in ECD after the implantation in our study, since many of our patients were long-term contact lens wearers prior to the implantation and many discontinued wearing their contact lenses postoperatively. Unfortunately, due to insufficient data, we were not able to analyze the relation between preoperative contact lens or spectacle use and postoperative endothelial cell values.

\section{Comparison to other long-term studies of refractive surgery}

Recently, a study was published on the long-term (12-year) results of patients who underwent myopic photorefractive keratectomy for the correction of myopia. The range of the preoperative SE was -1.5 to $-17.5 \mathrm{D}$. Seventy-five percent of patients who underwent a $-2 \mathrm{D}$ correction and $65 \%$ of patients who received a $-3 \mathrm{D}$ correction were within $1 \mathrm{D}$ of intended correction at 12 years. Fifty-seven percent of the $-4 \mathrm{D}$ group and $50 \%$ of the $-5 \mathrm{D}$ group were within $1 \mathrm{D}$, and this was further reduced to $25 \%$ and $22 \%$ in the $-6 \mathrm{D}$ and $-7 \mathrm{D}$ groups, respectively. In our study of Artisan PIOL implantation, $65.2 \%$ and $92.8 \%$ of patients were within $\pm 1.0 \mathrm{D}$ and $\pm 2.0 \mathrm{D}$ of the desired refraction after 10 years. The PRK study demonstrated that after 12 years, 94\% had a BCVA better than or equal to the preoperative BCVA. A loss of 1 Snellen line of BCVA was shown in $4.0 \%$ and of 2 Snellen lines of BCVA in 1.4\% of patients. Our data at 10 years showed a BCVA of $20 / 40$ or better in $92.5 \%$ of patients and a loss of more than 2 Snellen lines of BCVA in $3.6 \% .^{13}$

\section{Late complications}

No intra-operative or postoperative complications occurred in the patient group. Previous studies on Artisan PIOL implantation have discussed intra- and postoperative complications ${ }^{1,5,9,24}$ These studies demonstrated that intraoperative problems that can occur are usually minimal and typically related to the learning curve required to master the special implantation technique for the Artisan lens. We believe that the 2 eyes which developed a visually significant cataract 6 years 
after surgery were age- and high myopia related and not caused by the surgical implantation of the Artisan PIOL.

\section{Glare}

Glare levels were evaluated after 10 years follow-up. For this purpose, a validated questionnaire was applied, which represented the quantification of glare levels after the surgical procedure. ${ }^{16,18,19}$ The results demonstrated that glare levels after the Artisan PIOL implantation procedure were low and showed comparable results to previous PIOL studies. ${ }^{1,20}$

In conclusion, this study has demonstrated that after the implantation of Artisan PIOLs for the treatment of moderate to high myopia, refractive stability was maintained for up to 10 years. There was no evidence of late-onset complications or long-term endothelial cell loss. However, to achieve these results, a meticulous surgical technique of PIOL implantation by an adequately trained surgeon is needed and strict inclusion criteria must be applied. 


\section{REFERENCES}

1. Budo C, Hessloehl JC, Izak M, et al. Multicenter study of the Artisan phakic intraocular lens. J Cataract Refract Surg 2000;26:1163-71.

2. Dick HB, Alio J, Bianchetti M, et al. Toric phakic intraocular lens: European multicenter study. Ophthalmology 2003;110:150-62.

3. El Danasoury MA, El Maghraby A, Gamali TO. Comparison of iris-fixed Artisan lens implantation with excimer laser in situ keratomileusis in correcting myopia between -9.00 and -19.50 diopters: a randomized study. Ophthalmology 2002;109:955-64.

4. Guell JL, Vazquez M, Malecaze F, et al. Artisan toric phakic intraocular lens for the correction of high astigmatism. Am J Ophthalmol 2003;136:442-7.

5. Landesz M, van Rij G, Luyten G. Iris-claw phakic intraocular lens for high myopia. J Refract Surg 2001;17:634-40.

6. Malecaze FJ, Hulin H, Bierer P, et al. A randomized paired eye comparison of two techniques for treating moderately high myopia: LASIK and Artisan phakic lens. Ophthalmology 2002;109:1622-30.

7. Maloney RK, Nguyen LH, John ME. Artisan phakic intraocular lens for myopia: shortterm results of a prospective, multicenter study. Ophthalmology 2002;109:1631-41.

8. Menezo JL, Avino JA, Cisneros A, et al. Iris claw phakic intraocular lens for high myopia. J Refract Surg 1997;13:545-55.

9. Menezo JL, Cisneros AL, Rodriguez-Salvador V. Endothelial study of iris-claw phakic lens: four year follow-up. J Cataract Refract Surg 1998;24:1039-49.

10. Pop M, Payette Y. Initial results of endothelial cell counts after Artisan lens for phakic eyes: an evaluation of the United States Food and Drug Administration Ophtec Study. Ophthalmology 2004;111:309-17.

11. el Danasoury MA, Waring GO III, el Maghraby A, Mehrez K. Excimer laser in situ keratomileusis to correct compound myopic astigmatism. J Refract Surg 1997;13:511-20.

12. Knorz MC, Wiesinger B, Liermann A, et al. Laser in situ keratomileusis for moderate and high myopia and myopic astigmatism. Ophthalmology 1998;105:932-40.

13. Rajan MS, Jaycock P, O’Brart D, et al. A long-term study of photorefractive keratectomy; 12-year follow-up. Ophthalmology 2004;111:1813-24.

14. Hersh PS, Brint SF, Maloney RK, et al. Photorefractive keratectomy versus laser in situ keratomileusis for moderate to high myopia: a randomized prospective study. Ophthalmology 1998;105:1512-22, discussion 1522-3.

15. Pop M, Payette Y. Risk factors for night vision complaints after LASIK for myopia. Ophthalmology 2004;111:3-10.

16. Tahzib NG, Bootsma SJ, Eggink FA, et al. Functional outcomes and patient satisfaction after laser in situ keratomileusis for correction of myopia. J Cataract Refract Surg 2005;31:1943-51.

17. Benedetti S, Casamenti V, Marcaccio L, et al. Correction of myopia of 7 to 24 diopters with the Artisan phakic intraocular lens: two-year follow-up. J Refract Surg $2005 ; 21: 116-26$. 
18. Brunette I, Gresset J, Boivin JF, et al. Functional outcome and satisfaction after photorefractive keratectomy. Part 1: development and validation of a survey questionnaire. Ophthalmology 2000;107:1783-9.

19. Brunette I, Gresset J, Boivin JF, et al. Functional outcome and satisfaction after photorefractive keratectomy. Part 2: survey of 690 patients. Ophthalmology 2000;107:1790-6.

20. Tahzib NG, Bootsma SJ, Eggink FA, Nuijts RM. Functional outcome and patient satisfaction after Artisan phakic intraocular lens implantation for correction of myopia. Am J Ophthalmol 2006;142:31-9.

21. Chinn S. The assessment of methods of measurement. Stat Med 1990;9:351-62.

22. Bland JM, Altman DG. Applying the right statistics: analyses of measurement studies. Ultrasound Obstet Gynecol 2003;22:85-93.

23. Bland JM, Altman DG. Statistical methods for assessing agreement between two methods of clinical measurement. Lancet 1986;1:307-10.

24. Lifshitz T, Levy J, Aizenman I, et al. Artisan phakic intraocular lens for correcting high myopia. Int Ophthalmol 2004;25:233-8.

25. Amann J, Holley GP, Lee SB, Edelhauser HF. Increased endothelial cell density in the paracentral and peripheral regions of the human cornea. Am J Ophthalmol 2003;135:584-90.

26. Lim R, Mitchell P, Cumming RG. Refractive associations with cataract: the Blue Mountains Eye Study. Invest Ophthalmol Vis Sci 1999;40:3021-6.

27. Midelfart A, Kinge B, Midelfart S, Lydersen S. Prevalence of refractive errors in young and middle-aged adults in Norway. Acta Ophthalmol Scand 2002;80:501-5.

28. Wang Q, Klein BE, Klein R, Moss SE. Refractive status in the Beaver Dam Eye Study. Invest Ophthalmol Vis Sci 1994;35:4344-7.

29. Guell JL, Vazquez M, Gris O, et al. Combined surgery to correct high myopia: iris claw phakic intraocular lens and laser in situ keratomileusis. J Refract Surg 1999;15:529-37.

30. Kohnen T, Baumeister M, Magdowski G. Scanning electron microscopic characteristics of phakic intraocular lenses. Ophthalmology 2000;107:934-9.

31. Bourne WM, Nelson LR, Hodge DO. Central corneal endothelial cell changes over a ten-year period. Invest Ophthalmol Vis Sci 1997;38:779-82.

32. Schnitzer JI, Krachmer JH. A specular microscopic study of families with endothelial dystrophy. Br J Ophthalmol 1981;65:396-400.

33. van Schaick W, van Dooren BT, Mulder PG, Volker-Dieben HJ. Validity of endothelial cell analysis methods and recommendations for calibration in Topcon SP-2000P specular microscopy. Cornea 2005;24:538-44.

34. Vecchi M, Braccio L, Orsoni JG. The Topcon SP 1000 and Image-NET systems: a comparison of four methods for evaluating corneal endothelial cell density. Cornea 1996;15:271-7.

35. Landesz M, Kamps A, Slart R, et al. Morphometric analysis of the corneal endothelium with three different specular microscopes. Doc Ophthalmol 1995;90:15-28.

36. Erickson P, Doughty MJ, Comstock TL, Cullen AP. Endothelial cell density and contact lens-induced corneal swelling. Cornea 1998;17:152-7. 
37. Whikehart DR, Parikh CH, Vaughn AV, et al. Evidence suggesting the existence of stem cells for the human corneal endothelium. Mol Vis 2005;11:816-24.

38. Konomi K, Zhu C, Harris D, Joyce NC. Comparison of the proliferative capacity of human corneal endothelial cells from the central and peripheral areas. Invest Ophthalmol Vis Sci 2005;46:4086-91.

39. Edelhauser HF, Sanders DR, Azar R, Lamielle H, ICL in Treatment of Myopia Study Group. Corneal endothelial assessment after ICL implantation. J Cataract Refract Surg 2004;30:576-83.

40. Odenthal MT, Gan IM, Oosting J, et al. Long-term changes in corneal endothelial morphology after discontinuation of low gas-permeable contact lens wear. Cornea 2005;24:32-8.

41. Trocme SD, Mack KA, Gill KS, et al. Central and peripheral endothelial cell changes after excimer laser photorefractive keratectomy for myopia. Arch Ophthalmol 1996;114:925-8.

42. Stulting RD, Thompson KP, Waring GO III, Lynn M. The effect of photorefractive keratectomy on the corneal endothelium. Ophthalmology 1996;103:1357-65.

43. Perez-Santonja JJ, Sahla HF, Alio JL. Evaluation of endothelial cell changes 1 year after excimer laser in situ keratomileusis. Arch Ophthalmol 1997;115:841-6.

44. Collins MJ, Carr JD, Stulting RD, et al. Effects of laser in situ keratomileusis (LASIK) on the corneal endothelium 3 years postoperatively. Am J Ophthalmol 2001;131:1-6. 
Three year follow-up analysis of Artisan toric lens implantation for correction of postkeratoplasty ametropia in phakic and pseudophakic eyes

Tahzib NG, Cheng YYY, Nuijts RMMA.

Ophthalmology. 2006 Jun;113(6):976-84. 


\section{ABSTRACT}

Purpose: To determine the three year follow-up of efficacy and safety of Artisan toric iris-fixated lens implantation after penetrating keratoplasty to correct high ametropia and astigmatism.

Design: Prospective, noncomparative case series with a minimal follow-up of 1 year.

Participants: Artisan toric lens implantation was performed in 36 eyes of 35 patients who were contact lens intolerant or unable to wear glasses due to anisometropia and/or high astigmatism.

Intervention: Thirty-six eyes of 35 consecutive patients received Artisan toric lens implantation for postkeratoplasty astigmatism and/or anisometropia.

Main Outcome Measures: Manifest refraction, uncorrected and spectacle-corrected visual acuity (UCVA and BCVA), and corneal topography were performed before surgery, and at 3, 6, 12 months and yearly intervals up to 4 years after surgery. Efficacy, safety, percent reduction of refractive astigmatism, anisometropia of defocus and the astigmatism correction index were determined. A patient satisfaction questionnaire and specular microscopy were assessed.

Results: The mean \pm standard deviation of preoperative refractive cylinder was $-7.06 \pm$ 2.01 (range -3.0 to -11.0 ) diopters (D), which was reduced to $-1.73 \pm 1.25 \mathrm{D},-1.69 \pm$ $1.15 \mathrm{D},-1.94 \pm 1.68 \mathrm{D},-2.02 \pm 1.93 \mathrm{D}$ and $-2.00 \pm 1.53 \mathrm{D}$ at 6 months $(\mathrm{n}=36), 1$ year $(n=36), 2$ years $(n=29), 3$ years $(n=15)$ and the last follow-up examination $(28.5 \pm 12.5$ months, $\mathrm{n}=36)$, respectively $(P<0.001$ for all time points, paired t-test). The spherical equivalent was reduced from $-3.19 \pm 4.31 \mathrm{D}$ (range, +5.5 to $-14.25 \mathrm{D}$ ) preoperatively to $-1.03 \pm 1.20 \mathrm{D}$ (range, +1.0 to $-5.25 \mathrm{D}$ ) at the last follow-up. The UCVA and BCVA were $\geq 20 / 40$ in $31.6 \%$ and $80.6 \%$, respectively. There was a loss of BCVA of greater than 2 lines in $8.3 \%$ of eyes and a gain of at least 2 lines in $8.3 \%$ of eyes. The percent reduction in refractive astigmatism and anisometropia of defocus were $88.8 \pm 29.5 \%$ and $77.8 \pm$ $19.3 \%$, respectively. The astigmatism correction index was $96.0 \pm 24.2 \%$. Satisfaction increased from 3.6 to 8.0 (scale 0 to 10 ) post-implantation. The endothelial cell loss as compared to preoperatively was $13.8 \pm 18.7 \%(n=34), 21.2 \pm 21.8 \%(n=33), 29.6 \pm 27.3 \%$ $(\mathrm{n}=26), 30.4 \pm 32.0 \%(\mathrm{n}=18)$, and $34.8 \pm 26.3 \%(\mathrm{n}=6)$ at 6 months $(P=0.001), 1$ year $(P<0.001), 2$ years $(P<0.001), 3$ years $(P=0.001)$, and 4 years postoperatively $(P=0.1)$, respectively. In two patients irreversible graft rejections occurred and in one patient gradual endothelial decompensation occurred.

Conclusion: Artisan toric lens implantation after penetrating keratoplasty was effective for reduction of refractive astigmatism and ametropia. All patients were suitable for spectacle correction after implantation. There was a continuing endothelial cell loss from 6 months to 3 years postoperatively. In 3 cases corneal graft failure developed. 


\section{INTRODUCTION}

The purpose of the present study was to determine the three year efficacy and safety of toric iris-fixated intraocular lens (IOL) implantation for the reduction of anisometropia and astigmatism to allow spectacle wear in patients with contact lens intolerance after keratoplasty. Although visual function may show substantial improvement after keratoplasty ${ }^{1}$, report significant astigmatism of 4 to 5 diopters. ${ }^{2-5}$ It is well-known that patients do not tolerate spectacle correction for more than 3 to 4 diopters (D) of astigmatism or anisometropia. Therefore, contact lenses are fitted in 10\% to $30 \%$ of postkeratoplasty patients overall and in postkeratoplasty keratoconus patients this may increase up to $50 \% .^{6,7}$ Contact lenses may be effective in $80 \%$ of cases but contact lens intolerance in the postkeratoplasty population may be high due to ocular problems such as topographical abnormalities, blepharitis and dry eye, poor manual dexterity, occupational problems and lack of motivation. Surgical correction of postkeratoplasty astigmatism has been performed by corneal relaxing incisions ${ }^{8,9}$, wedge resections ${ }^{10}$, and IOL exchange or piggy-back implantation. ${ }^{11}, 12$ Recently, excimer laser photorefractive keratectomy (PRK) and laser in situ keratomileusis (LASIK) have been used for corneal tissue ablation. However, PRK causes significant haze in corneal grafts and induces irregular astigmatism and regression although recent adjunctive use of mitomycin C may prevent these side effects. ${ }^{13-16}$ LASIK surgery is able to treat a greater range of postkeratoplasty refractive error but the corneal graft thickness and the amount of ametropia and astigmatism suitable for correction limit the efficacy of the procedure. In addition, wound dehiscence due to the high vacuum pressure, flap complications in steep corneas and a high rate of retreatments may occur. ${ }^{17-25}$ Recently, we published the short-term preliminary results of Artisan toric lens implantation for the correction of postkeratoplasty refractive error. ${ }^{26}$ The present series provides the results with respect to safety and efficacy in a larger series with a follow-up up to 4 years.

\section{PATIENTS AND METHODS}

\section{Patient population}

The thirty-six eyes of 35 consecutive patients included in this study could not be corrected by spectacle wear because of anisometropia, the magnitude of refractive cylinder and/or were contact lens intolerant. Exclusion criteria were as follows: a preoperative spectacle best-corrected visual acuity (BCVA) worse than 20/60, an anterior chamber depth less than $3.0 \mathrm{~mm}$, glaucoma, retinal pathology likely to alter vision, or an endothelial cell count lower than 500 cells $/ \mathrm{mm}^{2}$. Investigational review board approval was obtained from the Academic Hospital Maastricht. 


\section{Examination findings}

Patients were examined preoperatively and at day 1 , week 1 , month 1 , month 3 , month 6, and from then at 6 months intervals. Preoperatively, uncorrected visual acuity (UCVA) and BCVA with subjective refraction, cycloplegic refraction, slit-lamp microscopy, applanation tonometry, corneal topography (Alcon Eyemap EH-290, Alcon, Fort Worth, TX), dilated fundus examination and pupil size measurement at dim illumination with the Colvard pupillometer (Oasis, Glendora, CA) were performed. On postoperative day 1, UCVA and BCVA and biomicroscopic examination with registration of intraocular pressure were performed. Thereafter, UCVA and BCVA with subjective refraction, slit-lamp microscopy, applanation tonometry, and corneal topography were assessed. The simulated keratometry values of the steep and flat meridians were used for calculation of the topographically induced surgical astigmatism. Preoperatively and at 6 months, 1 year, 2 years, and 3 years postoperatively, specular microscopy of the corneal endothelium using a noncontact specular microscope (Konan Noncon Robo, SP 8000, Konan, Hyogo, Japan) was performed. ${ }^{27,}{ }^{28}$ Preoperatively and at 6 months postoperatively, the patients were asked to rate the quality of vision of the eye with their present correction on a visual analog scale of 1 to 10 (1 is very poor, 10 is excellent), based on a previously validated questionnaire. ${ }^{29}$

\section{Surgical technique}

The Artisan toric IOL has a convex-concave toric optic with a spherical anterior surface and a sphero-cylindrical posterior surface (Ophtec B.V., Groningen, the Netherlands). This single-piece lens is composed of polymethyl methacrylate and is manufactured using compression molding technology. The toric lens is iris claw-fixated and has a $5-\mathrm{mm}$ optical zone (Figure 1). Refractive error, refractive cylinder power, anterior chamber depth, and topographically derived keratometric dioptric values were inserted into the Van der Heijde ${ }^{30}$ formula to calculate the dioptric power of the lens for two meridians. The axis of the cylinder identified by the subjective refraction was used to determine the axis of surgical enclavation. The power of the lens was chosen to obtain emmetropia $(n=30)$ or a postoperative spherical equivalent of $-1.0 \mathrm{D}(\mathrm{n}=4),-2.0 \mathrm{D}(\mathrm{n}=1)$ or $+1.0 \mathrm{D}(\mathrm{n}=1)$ to match the ametropia in the untreated eyes. The IOL is available in dioptric powers of -3.0 to $-20.5 \mathrm{D},+2.0$ to $+12.0 \mathrm{D}$ and in cylindrical powers of 2.0 to $7.5 \mathrm{D}$. The cylinder is in line with the haptics or at an angle of $90^{\circ}$ with the haptics. In 9 of 37 eyes the cylinder dioptric power of the toric lens was less than $75 \%$ of the calculated power required for full correction of the cylinder. The surgical techniques for lens implantation and the postoperative medical treatment have been described previously. ${ }^{16}$ 


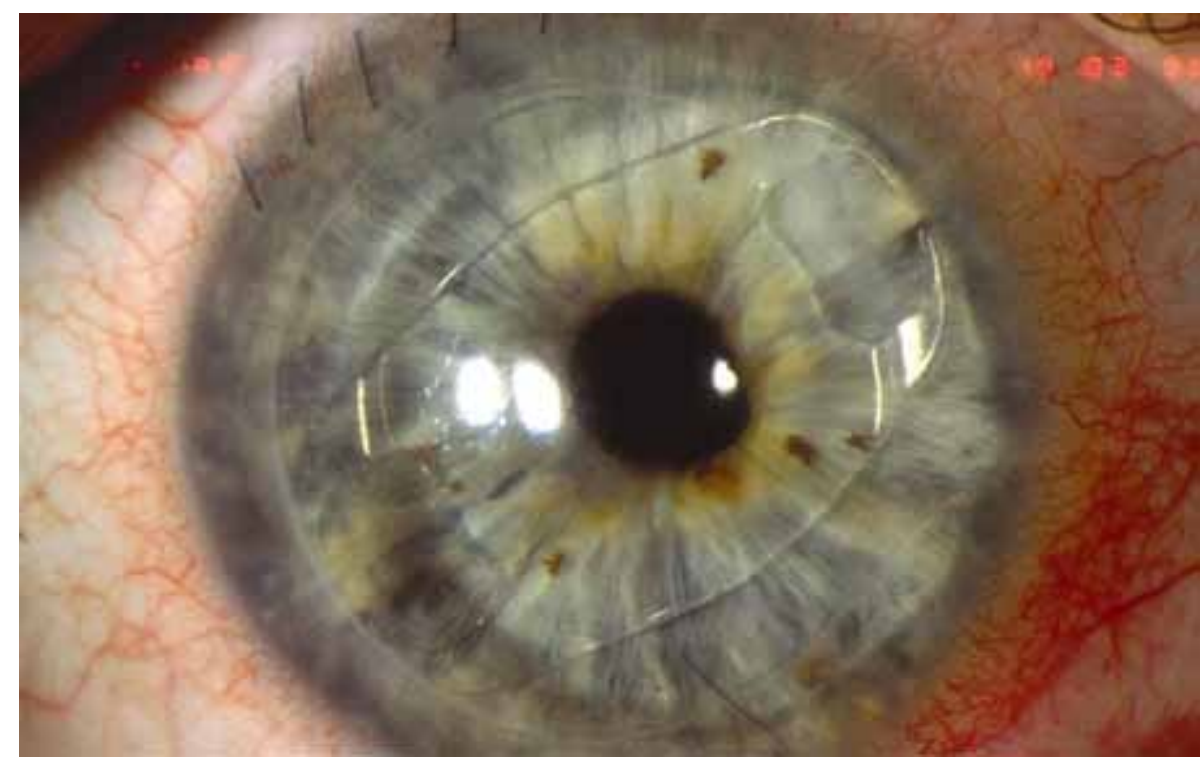

Figure 1. Artisan toric lens implantation for correction of postkeratoplasty astigmatism (patient no. 2). Preoperatively, BCVA was 20/50 with $+4.0-8.0 \times 120^{\circ}$. Six months after implantation of an Artisan toric lens with a power of $+6.0-7.0 \times 90^{\circ}$ and enclavated in the axis $30^{\circ}$, BCVA increased to $20 / 32$ with $-1.0-1.50 \times 125^{\circ}$ and UCVA to $20 / 60$. Four years after implantation UCVA is 20/30 with a clear graft. BCVA = best-corrected visual acuity; UCVA = uncorrected visual acuity.

\section{Outcome measures and statistics}

Main outcome measures were refractive and visual outcome as reflected by UCVA and efficacy (reduction in refractive and topographic astigmatism, reduction in anisometropia of spherical and defocus equivalent and number of eyes losing/gaining lines of UCVA, BCVA and safety (number of eyes losing more than 2 lines of BCVA). A patient satisfaction questionnaire, specular microscopy (endothelial cell loss) and incidence of complications were assessed. Snellen UCVA or BCVA was converted to logMar values to facilitate statistical analysis. Comparison between preoperative data and postoperative data was performed by paired t-test and comparison between groups by Pearson chi-square test (SPSS for Windows (SPSS Inc., Chicago, IL). All averages in the text are mean \pm standard deviation (SD).

\section{Analysis of astigmatism}

Both vector analysis and non-vector analysis of the cylinder was performed. The efficacy of the procedure (i.e., the proportion of astigmatism correction achieved) was quantified using the correction index expressed as a percentage of the surgi- 
cally induced astigmatism (SIA) divided by the target induced astigmatism (TIA) for each individual eye and aggregated. ${ }^{31}$ The Holladay method to convert polar values (cylinder and axis) to a Cartesian ( $\mathrm{X}$ and $\mathrm{Y}$ ) coordinate system was used to determine the mean \pm SD value of the refractive and topographical keratometric astigmatism. ${ }^{32}$ The coordinates were plotted in a doubled-angle plot and the centroid was determined.

\section{RESULTS}

\section{Patient population}

Twenty-seven patients were female and eight were male. The mean age was $63.8 \pm 17.0$ (range, 23-82 years). The mean time interval between penetrating keratoplasty and toric lens implantation was $57.1 \pm 30.2$ months (range, 26 to 142 months) and the interval between suture removal and lens implantation was 30.8 \pm 28.2 months (range, 3 to 144 months). Twenty-five eyes were pseudophakic after previous implantation of a posterior chamber IOL and one eye was aphakic. The initial diagnosis requiring corneal transplantation was Fuchs endothelial dystrophy (33.3\%), (pseudophakic) bullous keratopathy (13.9\%), Herpes Simplex keratitis (16.7\%), keratoconus (13.9\%), corneal scarring (11.1\%) re-grafting $(8.3 \%)$ and high astigmatism (2.8\%).

The baseline parameters were a mean sphere of $0.34 \pm 4.36 \mathrm{D}$ (range, +9.0 to $-10.0 \mathrm{D}$ ), a mean spherical equivalent refraction of $-3.19 \pm 4.31 \mathrm{D}$ (range, +5.5 to $-14.25 \mathrm{D}$ ), a mean baseline refractive cylinder power of $-7.06 \pm 2.01$ (range, -3.0 to $-11.0 \mathrm{D}$ ), a mean defocus equivalent of $6.99 \pm 2.59 \mathrm{D}$ (range, 3.25 to $14.25 \mathrm{D})$ and a mean baseline topographically derived simulated keratometric cylinder of $7.00 \pm 2.27 \mathrm{D}$ (range, +3.51 to $+11.65 \mathrm{D}$ ). There were no significant differences for the baseline parameters between the pseudophakic eye group and the phakic eye group. The mean follow-up was $28.5 \pm 12.5$ months (range, 12 to 51 months).

\section{Visual acuity outcome}

The mean $\log$ Mar UCVA preoperatively was $1.39 \pm 0.44$ and increased to $0.55 \pm$ 0.35 at the last follow-up $(P<0.001$, paired t-test). Postoperatively, $31.6 \%$ of eyes had a UCVA better than 20/40, 63.9\% of eyes better than $20 / 80$ as compared to $0 \%$ preoperatively. In the phakic and pseudophakic eye groups $27.8 \%$ and $35.3 \%$ of eyes had a UCVA better than 20/40, respectively ( $P=0.71$, Pearson chi-square). The mean number of gained lines of UCVA in all eyes was $8.50 \pm 5.51$ (range, -2 to 18 lines). The mean $\log$ Mar BCVA preoperatively was $0.26 \pm 0.17$ and postoperatively was $0.26 \pm 0.24(P=0.802$, paired t-test). Postoperatively, $80.6 \%$ of eyes had a BCVA better than $20 / 40$ as compared to $69.4 \%$ preoperatively and 


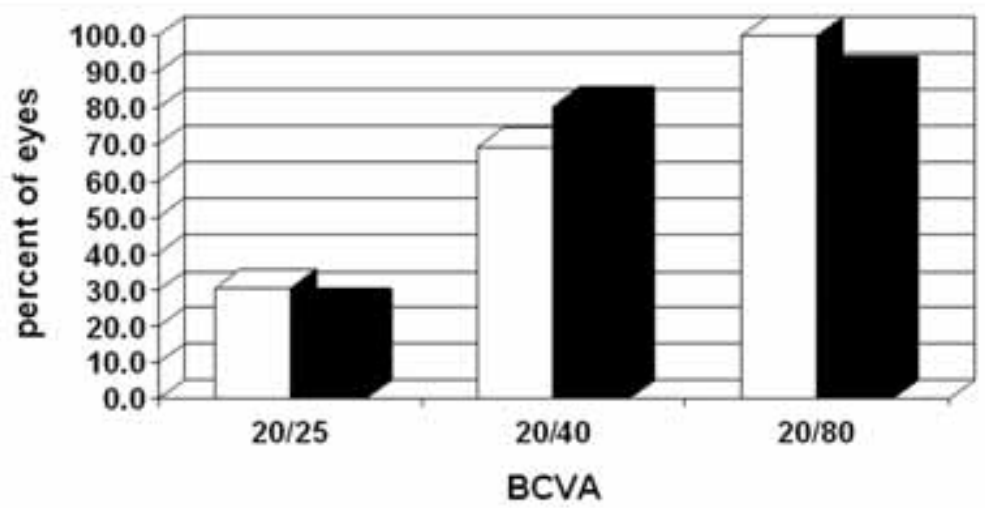

$\square$ Pre BCVA $\square$ Post BCVA

Figure 2. Percentage of eyes within given range of BCVA preoperatively and at last followup after toric lens implantation. The safety-index (mean postoperative BCVA divided by mean preoperative BCVA) was 0.98 . BCVA = best-corrected visual acuity.

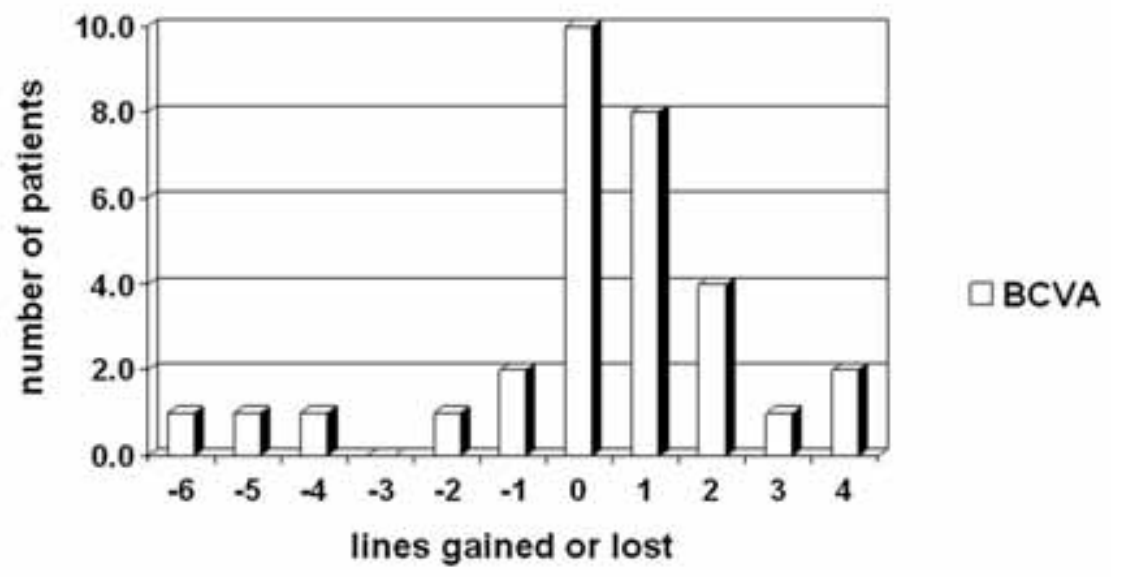

Figure 3. The number of gained or lost lines of BCVA at last follow-up after toric lens implantation. BCVA = best-corrected visual acuity. 

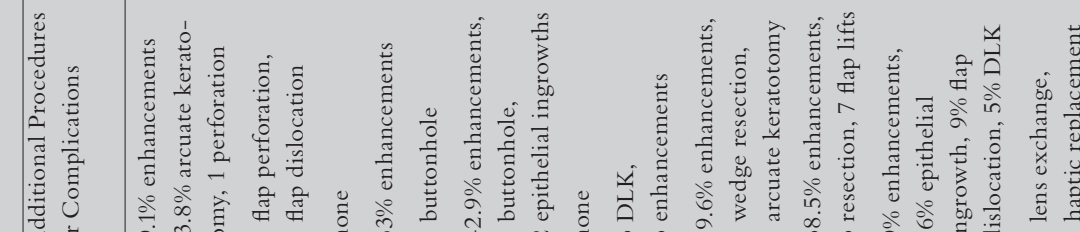

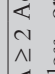

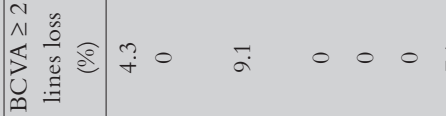

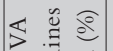

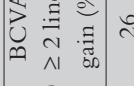

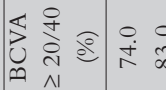

$\stackrel{\infty}{-}$

in $\frac{1}{2} \frac{1}{2}$

mo bे

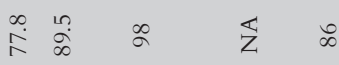

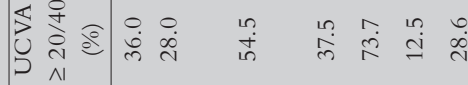

-

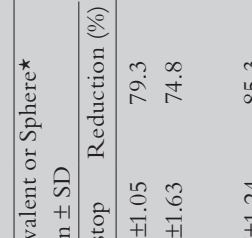

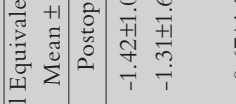

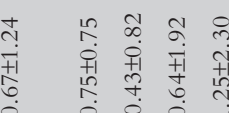

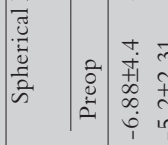

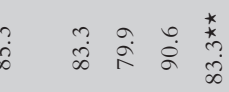

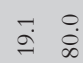

$\underset{\infty}{\stackrel{1}{i}}$

ลू

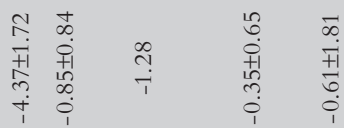

تี

@

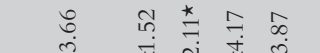

के $\bar{\infty}$

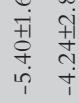

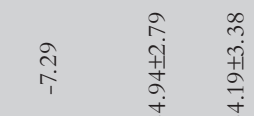

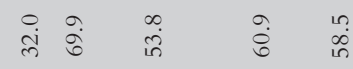

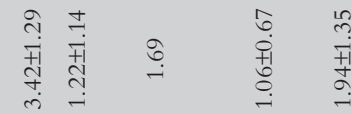

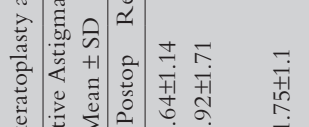

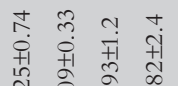

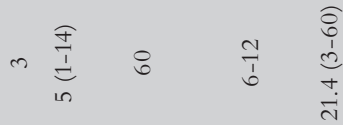


25.0\% had a BCVA better than 20/25 (Figure 2). In the phakic and pseudophakic eye groups $77.8 \%$ and $82.4 \%$ of eyes had a BCVA better than $20 / 40$, respectively $(P=0.83$, Pearson chi-square). The mean number of gained lines of BCVA in all eyes was $-0.06 \pm 2.14$ (range, -6 to 4 lines). There was a loss of BCVA of greater than 2 lines in $8.3 \%$ of eyes and a gain of at least 2 lines in $8.3 \%$ of eyes (Figure 3 ). The predictability of intended versus achieved cylinder correction showed 26 of 36 eyes (72.3\%) within $2 \mathrm{D}$ and 18 of 36 eyes (50.0\%) within $1 \mathrm{D}$ of the intended correction. In the phakic eye group $66.7 \%$ and $50.0 \%$ of eyes were within $2 \mathrm{D}$ and $1 \mathrm{D}$ of the intended correction, and in the pseudophakic eye group $76.5 \%$ and $52.9 \%$ of eyes were within $2 \mathrm{D}$ and $1 \mathrm{D}$ of the intended correction $(P=0.67$ and $P=0.59$, Pearson chi-square). The predictability of intended versus achieved defocus equivalent showed 22 of 36 eyes (61.1\%) within $2 \mathrm{D}$ and 9 of 36 eyes (25.0\%) within $1 \mathrm{D}$ of the intended correction.

\section{Refractive outcome}

The mean sphere at the last follow-up was $-0.03 \pm 1.23 \mathrm{D}$ (range, +2.50 to $-3.75 \mathrm{D}$ ), the mean spherical equivalent refraction was $-1.03 \pm 1.20 \mathrm{D}$ (range, +1.0 to $-5.25 \mathrm{D}$ ), and the mean defocus equivalent was $+1.65 \pm 1.67 \mathrm{D}$ (range, +7.13 to $+0.0 \mathrm{D})$. The refractive cylinder was reduced to $-1.73 \pm 1.25 \mathrm{D},-1.69 \pm$ $1.15 \mathrm{D},-1.94 \pm 1.68 \mathrm{D},-2.02 \pm 1.93 \mathrm{D}$ and $-2.00 \pm 1.53 \mathrm{D}$ at 6 months $(\mathrm{n}=36), 1$ year $(n=36), 2$ years $(n=29), 3$ years $(n=15)$ and the final follow-up examination (28.5 \pm 12.5 months), respectively $(P<0.001$ for all time points, paired t-test). There was no significant difference in refractive cylinder between the phakic eye group and the pseudophakic eye group at any of the postoperative time points. Concerning stability, there was no significant change in refractive cylinder values from 6 months postoperatively to 3 years postoperatively (Figure $4, P=0.065$, paired t-test).

At the last follow-up 10 of 36 eyes (27.8\%) had a refractive cylinder less than 1 D, 21 of 36 eyes (58.3\%) had a refractive cylinder less than 2 D, and 33 of 36 eyes $(91.7 \%)$ had a cylinder less than $4 \mathrm{D}$. The mean topographically derived simulated keratometric cylinder did not change significantly from $6.23 \pm 2.26$ $\mathrm{D}$ at 3 months postoperatively to $6.68 \pm 3.06 \mathrm{D}$ at 12 months $(P=0.968$, paired t-test $)$, and to $6.59 \pm 3.57 \mathrm{D}(P=0.894$, paired t-test $)$ at the last follow-up. The percent reduction in refractive and topographical astigmatism was $88.8 \pm 29.5 \%$ and $7.8 \pm 49.1 \%$, respectively (Table 1 ). In 9 eyes the required dioptric power for correction of the refractive astigmatism exceeded the available maximal cylindric power of $7.5 \mathrm{D}$. There was a reduction of $103.6 \pm 33.0 \%$ and $77.8 \pm 19.3 \%$ in sphere and defocus equivalent (for eyes with preoperative defocus values $>3.0 \mathrm{D}$, $\mathrm{n}=24$ ), respectively. The correction index (SIA/TIA) was $96.0 \pm 24.2 \%$ at the last follow-up. The centroid ( $\pm \mathrm{SD}$ ) in the double angled plot changed from $-2.83 \mathrm{D}$ at $141.3^{\circ}( \pm 6.43 \mathrm{D})$ preoperatively to $-0.51 \mathrm{D}$ at $91.9^{\circ}( \pm 2.15 \mathrm{D})$ postoperatively (Figure 5), $P<0.001$, (paired t-test). The mean surgically induced astigmatism of 


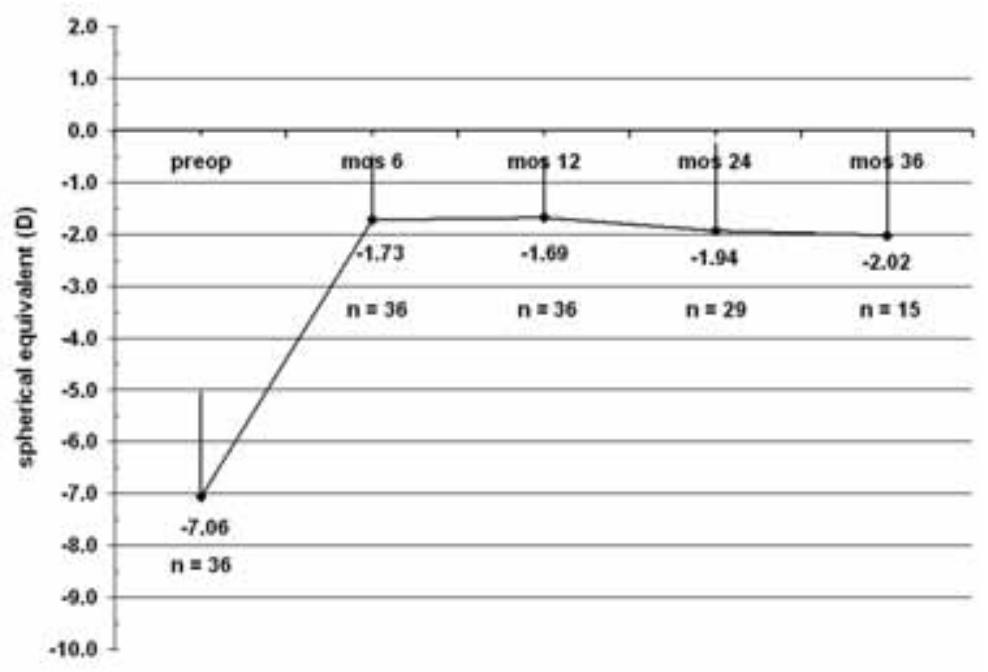

Figure 4. Mean refractive cylinder preoperatively and at postoperative time intervals. Number of patients at each time point are shown. $\mathrm{D}=$ diopters.

the topographical cylinder by the placement of the corneoscleral incision centered at $90^{\circ}$ was $2.53 \pm 1.57 \mathrm{D}$ (range, $0.25 \mathrm{D}$ to $6.25 \mathrm{D}$ ) at 6 months postoperatively. Patient satisfaction increased from 3.6 preoperatively to 8.0 postoperatively $(P<$ 0.001, paired t-test).

The intraocular pressure (IOP) was $14.5 \pm 2.9 \mathrm{mmHg}$ preoperatively, $15.2 \pm$ $4.2 \mathrm{mmHg}$ at 1 month postoperatively, $13.5 \pm 3.2 \mathrm{mmHg}$ at 6 months postoperatively, and $12.9 \pm 2.7 \mathrm{mmHg}$ at the last follow-up $(P=\mathrm{ns}$, paired t-test for all time points). The endothelial cell loss as compared to preoperatively was $13.8 \pm 18.7 \%(n=34), 21.2 \pm 21.8 \%(n=33), 29.6 \pm 27.3 \%(n=26), 30.4 \pm 32.0 \%$ $(\mathrm{n}=18)$, and $34.8 \pm 26.3 \%(\mathrm{n}=6)$ at 6 months $(P=0.001), 1$ year $(P<0.001), 2$ years $(P<0.001), 3$ years $(P=0.001)$, and 4 years postoperatively $(P=0.1)$, respectively. In addition there was a progressive endothelial loss from 6 months to 12 months $(P=0.004)$, to 24 months $(P=0.002)$ and to 36 months $(P=0.017)$, and from 12 months to 24 months $(P=0.016)$.

\section{Complications}

Two patients with irreversible graft rejections and one patient with gradual endothelial decompensation will be described.

A 77-year-old male (patient no. 6) underwent penetrating keratoplasty of the right eye in April 1997 for HSV stromal keratitis. Seven months after implantation of an Artisan toric lens with a power of $+5.0-7.0 \times 0^{\circ}$ BCVA increased to $20 / 25$ with $+0.75-1.50 \times 155^{\circ}$. One month later, metastasized lung cancer was diagnosed and a recurrence of HSV keratitis followed by irreversible graft 


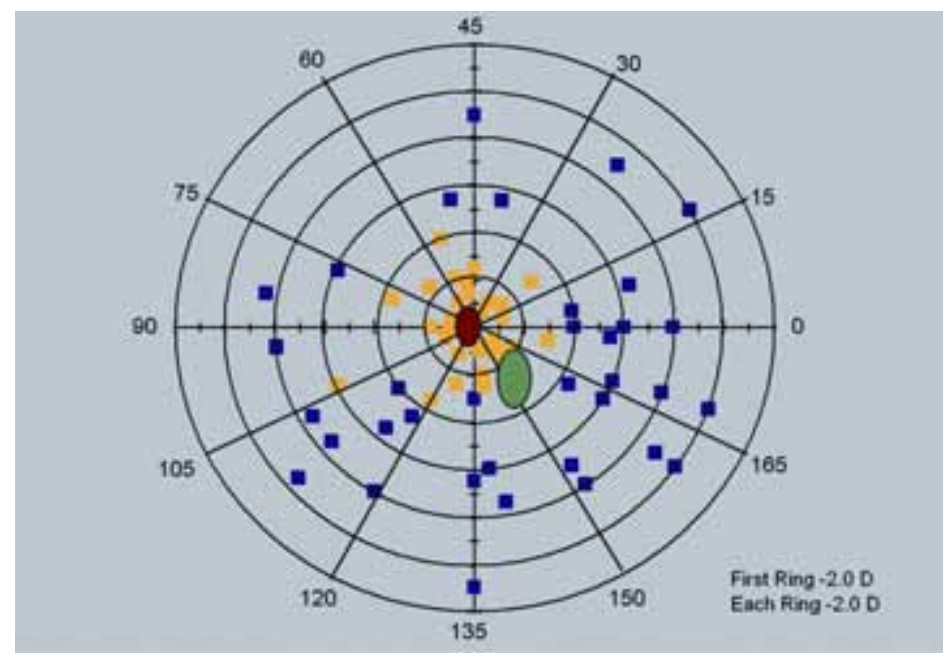

Figure 5. The centroid \pm standard deviation (SD) in the double angled plot changed from $-2.83 \mathrm{D}$ at $141.3^{\circ}( \pm 6.43 \mathrm{D})$ before Artisan toric lens implantation (blue squares, green centroid) to $-0.51 \mathrm{D}$ at $91.9^{\circ}( \pm 2.15 \mathrm{D})$ at the last follow-up after implantation (yellow squares, red centroid). $\mathrm{D}=$ diopters.

rejection developed. Twenty-five months after Artisan implantation, BCVA was $20 / 100$ with $+0.5-1.50 \times 160^{\circ}$. No further surgical treatment followed.

An 81-year-old female (patient no. 12) underwent penetrating keratoplasty of the left eye in September 1999 for pseudophakic bullous keratoplasty. Before Artisan implantation the endothelial cell density was $1384 \mathrm{cells} / \mathrm{mm}^{2}$. Five months after Artisan implantation (lens power of $-1.50-7.0 \times 0^{\circ}$, enclavation axis $162^{\circ}$ ) the BCVA was $20 / 30$ with $-0.75-2.25 \times 63^{\circ}$. At 12 months after Artisan toric lens implantation the endothelial cell density had decreased to 385 cells/ $\mathrm{mm}^{2}$. Twenty months after implantation, gradual endothelial decompensation occurred and BCVA decreased to 20/100 after metastasized colon cancer was diagnosed. Twenty-eight months after Artisan implantation, a re-keratoplasty, with explantation of the Artisan lens was performed. One year after re-keratoplasty the corneal graft was clear and BCVA was 20/30 with $-6.50 \times 0^{\circ}$.

A 62-year-old female (patient no. 18) underwent a re-penetrating keratoplasty of the right eye for graft failure in July 1999 after an intial keratoplasty for keratoconus in 1984. In May 2001, phacoemulsification with IOL implantation was performed followed by a reversible graft rejection in September 2001. In May 2003, seven months after Artisan implantation (lens power of $+8.0-7.5 \times 0^{\circ}$, enclavation axis $138^{\circ}$ ) the BCVA was $20 / 40$ with $-0.50-1.50 \times 50^{\circ}$. One month later an irreversible immunological graft failure occurred. In March 2004 a re-keratoplasty was performed with explantation of the toric Artisan lens. At the last follow-up in May 2005 the UCVA was 20/40 with a clear graft. 
In 6 patients signs of macular degeneration were noted. In patient no. 13 one haptic of the toric Artisan lens was repositioned 6 weeks after initial surgery because of axis misalignment and in patient no. 17 the Artisan lens was replaced because of an axis error in the delivered lens (lens power of $+7.0-7.5 \times 0^{\circ}$ in stead of $+7.0-7.5 \times 90^{\circ}$ ), not noted at the time of surgery. No chronic inflammation of the anterior chamber or retinal detachment was seen in any of the patients.

\section{DISCUSSION}

This prospective study of 36 eyes demonstrates the three year efficacy and stability of the Artisan toric intraocular lens (IOL) for correction of postkeratoplasty astigmatism. Until now, laser in situ keratomileusis (LASIK) appears to be the preferred technique for correction of anisometropia and astigmatism after keratoplasty (Table 1). ${ }^{17-25}$ The use of the Artisan toric IOL with a power range of 7.5 diopters (D) of cylinder and $-20.5 \mathrm{D}$ of myopia to $+12.0 \mathrm{D}$ of hyperopia, provides a wide field for correction of postkeratoplasty astigmatism and ametropia. In our series this is reflected by the magnitude of baseline spherical error (range +9.0 to $-10.0 \mathrm{D}$ ) and cylindrical error (range -3.0 to $-11.0 \mathrm{D}$ ), which is much higher than in most postkeratoplasty LASIK series. To our knowledge, the reduction of the refractive cylinder by $88.8 \pm 29.5$ (without any enhancements) is better than in most reported LASIK series. The reduction of refractive astigmatism after LASIK varies from $48 \%$ to $88 \%$ (Table 1). However, enhancements were reported in $9.1 \%{ }^{33}, 15 \%{ }^{34}, 42.9 \%{ }^{18}, 45 \%{ }^{35}$ and $53 \%{ }^{20}$ of cases and in one study LASIK was combined with arcuate incisions in the stromal bed in $54 \%$ of eyes. ${ }^{2}$

Improving the percentage of eyes with an uncorrected visual acuity (UCVA) of $20 / 40$ or better from $0 \%$ preoperatively to $31.6 \%$ at the last follow-up illustrates the efficacy of the Artisan toric IOL procedure in this patient group with highly ametropic eyes. In most LASIK series with lower preoperative ametropia UCVA better than 20/40 varied from 28\% to 74\%.2, 18, 20,22, 33,34 With respect to safety, there was a loss of best-corrected visual acuity (BCVA) of greater than 2 lines in $8.3 \%$ of eyes and a gain of at least 2 lines in $8.3 \%$ of eyes. This is in accordance with two recent randomized studies in routine refractive surgery for the correction of high myopia that showed a greater gain of BCVA with Artisan phakic intraocular lens implantation as compared to a greater loss of BCVA with LASIK and a better quality of vision with the Artisan lens in moderate to high myopia. ${ }^{36}$, 37 The loss of greater than 2 lines of BCVA in $8.3 \%$ in our series is comparable to series of LASIK for postkeratoplasty astigmatism that show a greater than 2 lines loss of BCVA in $4.3 \%{ }^{38}, 7.1 \%{ }^{18}, 9.1 \% \cdot{ }^{22}$ and $16 \% .{ }^{23}$ However, the pattern of complications induced by the two techniques is very different. LASIK surgery may be complicated by flap complications in steep corneas and has limitations due to corneal graft thickness and amount of ametropia and astigmatism suitable for correction. ${ }^{17-25}$ LASIK related complications like diffuse lamellar keratitis ${ }^{34}$, 
buttonhole flaps ${ }^{18,22}$, wound dehiscence ${ }^{39}$ and epithelial ingrowth ${ }^{18}$ have been reported. Because the majority of eyes in the reported LASIK series were grafted in young patients for keratoconus with a rapid wound healing, wound dehiscence problems were less likely to occur than in a group of older patients grafted for Fuchs endothelial dystrophy or bullous keratopathy. ${ }^{40}$ Since the effect of the flap cut alone may induce a significant reduction of refractive astigmatism in up to $50 \%$ in some patients and because of the high enhancement rate a two-stage LASIK procedure has been proposed. ${ }^{17,41-43}$ However, it is unclear whether a two-stage procedure bears a higher risk for complications like epithelial ingrowth, wound healing problems and flap dislocation. In our present Artisan series, irreversible corneal decompensation occurred in two patients after metastasized cancer was diagnosed. Before the diagnosis of malignant disease BCVA was 20/25 in both patients and no signs of immunological rejection had been noted. We believe that changes in the immune system due to the concomitant development of malignant systemic disease might have initiated the graft failures. In a third patient with a re-keratoplasty for a graft failure after an initial diagnosis of keratoconus an immunological irreversible graft failure occurred. This was the second rejection period after the re-keratoplasty following a previous reversible rejection period 4 months after cataract surgery. We can not exclude that the last rejection, although 8 months after surgery, may have been related to the Artisan toric lens implantation. Two of the three cases with corneal decompensation underwent succesful regrafting with explantation of the toric Artisan intraocular lens. In 6 patients signs of adult retinal macular degeneration that decreased best corrected visual acuity were seen as can be expected in this age group. No other complications like chronic inflammation of the anterior chamber or retinal detachment in any of the patients were noted.

The stability of the postoperative refractive cylinder after Artisan toric lens implantation up to 36 months was excellent. After LASIK however, progressive changes were seen in refraction and topography in $35.7 \%$ of cases after a mean follow-up time of 26.9 months. ${ }^{18}$ A potential limitation of the Artisan toric IOL for the correction of postkeratoplasty astigmatism is surgically induced astigmatism by implantation of the rigid polymethylmethacrylate IOL through a $5.3 \mathrm{~mm}$ incision. In a recent series of implantation of the Artisan toric IOL for correction of myopia or hyperopia with astigmatism the surgically induced astigmatism was 0.53 D. ${ }^{44}$ However, after keratoplasty the biomechanical response of the corneoscleral tissue to the incision may be somewhat unpredictable and a greater variability in surgically induced astigmatism may be seen. Indeed, in our series the mean surgically induced astigmatism was $2.53 \mathrm{D}$ six months postoperatively and varied from $0.25 \mathrm{D}$ to $6.25 \mathrm{D}$. Due to this variability we believe that the surgically induced astigmatism cannot be incorporated into the power calculation of the lens. Since the goal of correcting postkeratoplasty astigmatism is mainly to reduce the refractive astigmatism and ametropia to enable patients to wear 
spectacles we feel that a lesser predictability of astigmatism reduction may be acceptable.

Concerns have been raised especially with respect to the development of complications such as endothelial cell loss, chronic inflammation and cystoid macular edema after Artisan toric lens implantation. A study using fluorometry showed inflammation comparable with cataract surgery at 6 months postoperatively ${ }^{45}$ whereas a study using a flare-cell meter found chronic inflammation 1 to 2 years after implantation of the older Worst-Fechner intraocular lens. ${ }^{46}$ We found no chronic inflammation by slit-lamp examination in the present study and cystoid macular edema with concomitant loss of BCVA was not seen in the immediate postoperative phase.

The mean endothelial cell loss was $13.8 \pm 18.7 \%, 21.2 \pm 21.8 \%, 29.6 \pm 27.3 \%$, and $30.4 \pm 32.0 \%$ at $6,12,24$ and 36 months. There was a significant continuing progressive endothelial cell loss at each time point as compared to preoperative cell density levels and between 6 months as compared to 12, 24, and 36 months. For an experienced surgeon the implantation of the Artisan toric lens in postkeratoplasty eyes does not appear to be more traumatic as compared to Artisan lens implantation in phakic eyes for correction of myopia. However, the cell loss in the present series is much higher than the reported cell loss in studies of Artisan lens implantation for correction of high myopia up to 2 years postoperatively which varies from $1.76 \%^{36}, 0.87 \%{ }^{47}$ and $7.2 \%{ }^{48}$ at 1 year to $0.78 \%{ }^{47}$ and $9.1 \%{ }^{48}$ at 2 years. Probably, the higher cell loss is explained by the increased vulnerability of the corneal graft endothelium that usually has low cell densities and may cause a higher rate of endothelial cell loss. After routine keratoplasty, the annual rate of endothelial cell loss from 3 to 5 years after keratoplasty is $7.8 \%$ per year ${ }^{49}$ and from 5 to 10 years is $4.2 \%$ per year. ${ }^{49-51}$ A recent study showed that the rate of cell loss from 10 to 15 years after penetrating keratoplasty is similar to normal corneas. ${ }^{51}$ At the time of toric Artisan lens implantation 50\% of our patients were between 3 to 5 years, $27.7 \%$ between 5 to 10 years and 5.6\% longer than 10 years after penetrating keratoplasty. For our 24 months cohort, the cell loss rate was $14.8 \%$ per year and for the 36 months cohort $10.1 \%$ per year. If we correct these values for the expected cell loss induced by the penetrating keratoplasty, there appears to be an additional cell loss of $6 \%$ to $7 \%$ per year. Therefore, we can not exclude that the Artisan iris-fixated IOL in the presence of a corneal graft with low cell densities may cause a higher rate of endothelial cell loss due to the compromised endothelium. However, the accuracy of non-contact specular microscopy for determining endothelial cell density which is usually around $5 \%$ is not known in grafts with low cell counts and may introduce bias in the interpretation of our results. ${ }^{52,53}$ Risk factors for endothelial decompensation in corneal grafts with low cell densities have not been clearly defined. Cell counts as low as 370 cells $/ \mathrm{mm}^{2}$ and 515 cells $/ \mathrm{mm}^{2}$ have been measured before decompensation. ${ }^{54-57}$ Although the only patient (patient no. 12) that developed corneal decompensation (without concommittant immunological rejection) in our series had an 
endothelial cell density of 1384 cells $/ \mathrm{mm}^{2}$ before Artisan implantation, we feel that the endothelial cell density of at least 500 cells $/ \mathrm{mm}^{2}$ as exclusion criterium probably should be increased to prevent corneal decompensation. However, one should bear in mind that in many of our cases with postkeratoplasty ametropia no other treatment modalities exist but corneal regrafting, and the Artisan lens is perfectly removable at future regrafting procedures as has been shown in two patients in our series.

Based on the objective medical outcomes, the subjective patient satisfaction that increased from 3.6 preoperatively to 8.0 postoperatively (scale 1-10) and the suitability of all patients for spectacle correction Artisan toric lens implantation appears to be a valuable option for correction of postkeratoplasty astigmatism and anisometropia. However, a cautious use of Artisan toric lens implantation is needed since we found a progressive endothelial cell loss in these corneas with a compromised endothelium. Therefore, more patients with a longer follow-up up to 5 years are needed to identify the risk factors for progressive endothelial cell loss and a randomized study of Artisan toric lens implantation versus LASIK with larger numbers of patients could clarify the advantages and disadvantages of both techniques with respect to efficacy, safety and complications. 


\section{REFERENCES}

1. Brahma A, Ennis F, Harper R, Ridgway A, Tullo A. Visual function after penetrating keratoplasty for keratoconus: a prospective longitudinal evaluation. Br J Ophthalmol 2000;84:60-6.

2. Webber SK, Lawless MA, Sutton GL, Rogers CM. LASIK for post penetrating keratoplasty astigmatism and myopia. Br J Ophthalmol 1999;83:1013-8.

3. Troutman RC, Lawless MA. Penetrating keratoplasty for keratoconus. Cornea 1987;6:298-305.

4. Binder PS. The effect of suture removal on postkeratoplasty astigmatism. Am J Ophthalmol 1988;106:507.

5. Seitz B, Langenbucher A, Kus MM, Kuchle M, Naumann GO. Nonmechanical corneal trephination with the excimer laser improves outcome after penetrating keratoplasty. Ophthalmology 1999;106:1156-64; discussion 1165.

6. Lopatynsky M, Cohen EJ, Leavitt KG, Laibson PR. Corneal topography for rigid gas permeable lens fitting after penetrating keratoplasty. Clao J 1993;19:41-4.

7. Eggink FA, Nuijts RM. A new technique for rigid gas permeable contact lens fitting following penetrating keratoplasty. Acta Ophthalmol Scand 2001;79:245-50.

8. Solomon A, Siganos CS, Frucht-Pery J. Relaxing incision guided by videokeratography for astigmatism after keratoplasty for keratoconus. J Refract Surg 1999;15:343-8.

9. Koay PY, McGhee CN, Crawford GJ. Effect of a standard paired arcuate incision and augmentation sutures on postkeratoplasty astigmatism. J Cataract Refract Surg 2000;26:553-61.

10. Lugo M, Donnenfeld ED, Arentsen JJ. Corneal wedge resection for high astigmatism following penetrating keratoplasty. Ophthalmic Surg 1987;18:650-3.

11. Fenzl RE, Gills JP, 3rd, Gills JP. Piggyback intraocular lens implantation. Curr Opin Ophthalmol 2000;11:73-6.

12. Gayton JL, Sanders V, Van der Karr M, Raanan MG. Piggybacking intraocular implants to correct pseudophakic refractive error. Ophthalmology 1999;106:56-9.

13. Bilgihan K, Ozdek SC, Akata F, Hasanreisoglu B. Photorefractive keratectomy for post-penetrating keratoplasty myopia and astigmatism. J Cataract Refract Surg 2000;26:1590-5.

14. Tuunanen TH, Ruusuvaara PJ, Uusitalo RJ, Tervo TM. Photoastigmatic keratectomy for correction of astigmatism in corneal grafts. Cornea 1997;16:48-53.

15. Amm M, Duncker GI, Schroder E. Excimer laser correction of high astigmatism after keratoplasty. J Cataract Refract Surg 1996;22:313-7.

16. Chang DH, Hardten DR. Refractive surgery after corneal transplantation. Curr Opin Ophthalmol 2005;16:251-5.

17. Busin M, Arffa RC, Zambianchi L, Lamberti G, Sebastiani A. Effect of hinged lamellar keratotomy on postkeratoplasty eyes. Ophthalmology 2001;108:1845-51; discussion $1851-2$.

18. Kwitko S, Marinho DR, Rymer S, Ramos Filho S. Laser in situ keratomileusis after penetrating keratoplasty. J Cataract Refract Surg 2001;27:374-9. 
19. Koay PY, McGhee CN, Weed KH, Craig JP. Laser in situ keratomileusis for ametropia after penetrating keratoplasty. J Refract Surg 2000;16:140-7.

20. Rashad KM. Laser in situ keratomileusis for correction of high astigmatism after penetrating keratoplasty. J Refract Surg 2000;16:701-10.

21. Nassaralla BR, Nassaralla JJ. Laser in situ keratomileusis after penetrating keratoplasty. J Refract Surg 2000;16:431-7.

22. Forseto AS, Francesconi CM, Nose RA, Nose W. Laser in situ keratomileusis to correct refractive errors after keratoplasty. J Cataract Refract Surg 1999;25:479-85.

23. Hardten DR, Chittcharus A, Lindstrom RL. Long term analysis of LASIK for the correction of refractive errors after penetrating keratoplasty. Cornea 2004;23:479-89.

24. Buzard K, Febbraro JL, Fundingsland BR. Laser in situ keratomileusis for the correction of residual ametropia after penetrating keratoplasty. J Cataract Refract Surg 2004;30:1006-13.

25. Barraquer CC, Rodriguez-Barraquer T. Five-year results of laser in-situ keratomileusis (LASIK) after penetrating keratoplasty. Cornea 2004;23:243-8.

26. Nuijts RM, Abhilakh Missier KA, Nabar VA, Japing WJ. Artisan toric lens implantation for correction of postkeratoplasty astigmatism. Ophthalmology 2004;111:1086-94.

27. Waring GO, 3rd. Standard graphs for reporting refractive surgery. J Refract Surg 2000;16:459-66.

28. Koch DD, Kohnen T, Obstbaum SA, Rosen ES. Format for reporting refractive surgical data. J Cataract Refract Surg 1998;24:285-7.

29. Nijkamp MD, Dolders MG, de Brabander J, van den Borne B, Hendrikse F, Nuijts RM. Effectiveness of multifocal intraocular lenses to correct presbyopia after cataract surgery: a randomized controlled trial. Ophthalmology 2004;111:1832-9.

30. van der Heijde GL, Fechner PU, Worst JG. [Optical consequences of implantation of a negative intraocular lens in myopic patients]. Klin Monatsbl Augenheilkd 1988;193:99-102.

31. Alpins N. Astigmatism analysis by the Alpins method. J Cataract Refract Surg 2001;27:31-49.

32. Holladay JT, Cravy TV, Koch DD. Calculating the surgically induced refractive change following ocular surgery. J Cataract Refract Surg 1992;18:429-43.

33. Donnenfeld ED, Solomon R, Biser S. Laser in situ keratomileusis after penetrating keratoplasty. Int Ophthalmol Clin 2002;42:67-87.

34. Malecha MA, Holland EJ. Correction of myopia and astigmatism after penetrating keratoplasty with laser in situ keratomileusis. Cornea 2002;21:564-9.

35. Guell JL, Gris O, de Muller A, Corcostegui B. LASIK for the correction of residual refractive errors from previous surgical procedures. Ophthalmic Surg Lasers 1999;30:341-9.

36. Malecaze FJ, Hulin H, Bierer P, et al. A randomized paired eye comparison of two techniques for treating moderately high myopia: LASIK and artisan phakic lens. Ophthalmology 2002;109:1622-30. 
37. El Danasoury MA, El Maghraby A, Gamali TO. Comparison of iris-fixed Artisan lens implantation with excimer laser in situ keratomileusis in correcting myopia between -9.00 and -19.50 diopters: a randomized study. Ophthalmology 2002;109:955-64.

38. Donnenfeld ED, Kornstein HS, Amin A, et al. Laser in situ keratomileusis for correction of myopia and astigmatism after penetrating keratoplasty. Ophthalmology 1999;106:1966-74; discussion 1974-5.

39. Ranchod TM, McLeod SD. Wound dehiscence in a patient with keratoconus after penetrating keratoplasty and LASIK. Arch Ophthalmol 2004;122:920-1.

40. Abou-Jaoude ES, Brooks M, Katz DG, Van Meter WS. Spontaneous wound dehiscence after removal of single continuous penetrating keratoplasty suture. Ophthalmology 2002;109:1291-6; discussion 1297.

41. Busin M, Zambianchi L, Garzione F, Maucione V, Rossi S. Two-stage laser in situ keratomileusis to correct refractive errors after penetrating keratoplasty. J Refract Surg 2003;19:301-8.

42. Alio JL, Javaloy J, Osman AA, Galvis V, Tello A, Haroun HE. Laser in situ keratomileusis to correct post-keratoplasty astigmatism; 1-step versus 2-step procedure. J Cataract Refract Surg 2004;30:2303-10.

43. Dada T, Vajpayee RB, Gupta V, Sharma N, Dada VK. Microkeratome-induced reduction of astigmatism after penetrating keratoplasty. Am J Ophthalmol 2001;131:507-8.

44. Dick HB, Alio J, Bianchetti M, et al. Toric phakic intraocular lens: European multicenter study. Ophthalmology 2003;110:150-62.

45. Perez-Santonja JJ, Bueno JL, Zato MA. Surgical correction of high myopia in phakic eyes with Worst-Fechner myopia intraocular lenses. J Refract Surg 1997;13:268-81; discussion 281-4.

46. Perez-Santonja JJ, Iradier MT, Benitez del Castillo JM, Serrano JM, Zato MA. Chronic subclinical inflammation in phakic eyes with intraocular lenses to correct myopia. J Cataract Refract Surg 1996;22:183-7.

47. Pop M, Payette Y. Initial results of endothelial cell counts after Artisan lens for phakic eyes: an evaluation of the United States Food and Drug Administration Ophtec Study. Ophthalmology 2004;111:309-17.

48. Landesz M, Worst JG, van Rij G. Long-term results of correction of high myopia with an iris claw phakic intraocular lens. J Refract Surg 2000;16:310-6.

49. Bourne WM, Hodge DO, Nelson LR. Corneal endothelium five years after transplantation. Am J Ophthalmol 1994;118:185-96.

50. Bourne WM, Nelson LR, Hodge DO. Continued endothelial cell loss ten years after lens implantation. Ophthalmology 1994;101:1014-22; discussion 1022-3.

51. Patel SV, Hodge DO, Bourne WM. Corneal endothelium and postoperative outcomes 15 years after penetrating keratoplasty. Am J Ophthalmol 2005;139:311-9.

52. Binder PS, Akers P, Zavala EY. Endothelial cell density determined by specular microscopy and scanning electron microscopy. Ophthalmology 1979;86:1831-47.

53. Laing RA. Specular microscopy of the cornea. Curr Top Eye Res 1980;3:157-218.

54. Hoffer KJ. Corneal decomposition after corneal endothelium cell count. Am J Ophthalmol 1979;87:252-3. 
55. Nuyts RM, Boot N, van Best JA, Edelhauser HF, Breebaart AC. Long term changes in human corneal endothelium following toxic endothelial cell destruction: a specular microscopic and fluorophotometric study. Br J Ophthalmol 1996;80:15-20.

56. Breebaart AC, Nuyts RM, Pels E, Edelhauser HF, Verbraak FD. Toxic endothelial cell destruction of the cornea after routine extracapsular cataract surgery. Arch Ophthalmol 1990;108:1121-5.

57. Armitage WJ, Dick AD, Bourne WM. Predicting endothelial cell loss and long-term corneal graft survival. Invest Ophthalmol Vis Sci 2003;44:3326-31. 
158

Chapter 7 


\section{Artisan iris-fixated toric phakic and aphakic intraocular lens implantation for the correction of astigmatic refractive error after radial keratotomy}

Tahzib NG, Eggink FAGJ, Odenthal MTP, Nuijts RMMA.

J Cataract Refract Surg. 2007 Mar;33(3):531-5. 


\section{ABSTRACT}

We report two patients who had previously undergone radial keratotomy (RK) to correct myopia. The first patient developed a postoperative hyperopic shift and cataract. Nine years after the RK, she underwent an intracapsular cataract extraction and implantation of an Artisan aphakic intraocular lens (IOL). Twenty years post-RK, hyperopia and astigmatism progressed to $+7.0-5.75 \times 100^{\circ}$ with a best-corrected visual acuity (BCVA) of 20/20. Due to contact lens intolerance, the Artisan aphakic IOL was exchanged for an Artisan toric aphakic IOL. Three months later, the BCVA was 20/20 with +1.0 -0.50 $\mathrm{x} 130^{\circ}$. The second patient demonstrated residual myopic astigmatism six years after bilateral RK and had become contact lens intolerant. We treated the patient by the implantation of an Artisan toric phakic IOL in both eyes. Four months later, the BCVA was $20 / 25$ and $20 / 20$ with a refraction of $+0.25-1.0 \times 135^{\circ}$ and $-1.0 \times 40^{\circ}$, respectively. Both patients were satisfied with their visual outcome. 


\section{INTRODUCTION}

Before the introduction of excimer laser technology, radial keratotomy (RK) was the most commonly performed refractive surgical procedure to correct myopia. The development of a hyperopic shift and diurnal fluctuations in visual acuity are common and troublesome side effects after this refractive surgery procedure. ${ }^{1-4}$ The development of high astigmatism after RK is a less common side-effect., ${ }^{1,5}$ The implantation of an Artisan toric phakic or aphakic intraocular lens (IOL) offers a good alternative to correct astigmatic error, allowing spherical and cylindrical correction in one procedure. ${ }^{6-9}$ The lens is composed of polymethyl methacrylate and has a convex-concave optic with a spherical anterior surface and a sphero-cylindrical posterior surface with a 5-mm optical zone (Ophtec B.V., Groningen, the Netherlands). The aphakic lens model is also available with a convex-convex optic configuration. Recent results on Artisan toric IOL implantations in normal virgin eyes show that $63 \%$ to $73 \%$ reach \pm 0.50 diopters (D) of the predicted correction with a best-corrected visual acuity improvement in $65.7 \%$ to $70 \%$ of eyes. ${ }^{6-8}$

We demonstrate two patients, one with progressive hyperopia and astigmatism after a previous RK procedure for the correction of a moderate myopia followed by an intracapsular cataract extraction with the implantation of an Artisan aphakic IOL. The other patient presented with bilateral residual myopia after a previous bilateral RK procedure. The two patients were eventually treated by the implantation of an Artisan toric aphakic and an Artisan toric phakic IOL with a satisfactory refractive outcome.

\section{Case reports}

For both patients, IOL power calculations were performed by Ophtec BV Groningen, the Netherlands. The axis of the cylinder identified by the subjective refraction was used to determine the axis of surgical enclavation. Toric IOLs are available with the cylinder in line with the haptics or at an angle of $90^{\circ}$ with the haptics. ${ }^{8}$ An IOL with the cylinder in line with the haptics is recommended when the preoperative cylinder is between $0^{\circ}$ and $45^{\circ}$ or between $135^{\circ}$ and $180^{\circ}$. The toric phakic Artisan IOL is available in cylindrical powers up to $+7.0 \mathrm{D}$ and the toric aphakic Artisan IOL is available in cylindrical powers up to $+4.0 \mathrm{D}$. These lenses are custom- and patient-designed. The IOL power was calculated in order to obtain emmetropia. The enclavation sites were marked on the limbus with a marker right before the surgical implantation, with the patient sitting upright. 


\section{Case 1}

A 74-year-old female was referred to our university clinic due to progressive visual complaints in her right eye. Twenty years earlier, she had undergone a bilateral uneventful radial keratotomy $(\mathrm{RK})$ procedure for the correction of a moderate myopia of $-5.0 \mathrm{D}$ in both eyes. The procedure included $8 \mathrm{RK}$ incisions in the right eye. The right eye demonstrated a progressive hyperopic shift after the RK procedure. Nine years after the RK procedure, the right eye underwent an uneventful intracapsular cataract extraction with a subsequent implantation of an Artisan aphakic IOL (IOL power 23.0 D). After this procedure, the bestcorrected visual acuity (BCVA) in the right eye was $20 / 25$ with $+3.0-4.0 \mathrm{x}$ $120^{\circ}$.

Twenty years after the RK procedure, the preoperative BCVA in the right eye was $20 / 20$ with a refraction of $+7.0-5.75 \times 100^{\circ}$. Topographic keratometry (EyeMap EH-290, Alcon, Forth Worth, TX) values were $32.1 \times 10^{\circ}$ and $25.8 \times 100^{\circ}$ (Fig. 1). The endothelial cell density (ECD) was 1633 cells $/ \mathrm{mm}^{2}$ (Noncon ROBO Pachy SP-9000, Konan Medical Inc, Tokyo, Japan). The anterior chamber depth (ACD) was $3.45 \mathrm{~mm}$ (OCT Visante, Carl Zeiss AG, Germany) and the axial length was $26.04 \mathrm{~mm}$. The intraocular pressure was $13 \mathrm{mmHg}$.

Lens power calculations were performed (Haigis formula) using the topographically derived keratometric $(\mathrm{K}) 1(32.1 \mathrm{D})$ and $\mathrm{K} 2(25.8 \mathrm{D})$ meridians and the axial length. This resulted in IOL powers of $24.6 \mathrm{D}$ (K1) and $30.5 \mathrm{D}$ (K2) for emmetropia. In addition, the patient's residual refractive error in her eye with the Artisan aphakia lens was taken into account for the selection of the necessary lens power. Because the maximal cylindrical power is $+4.0 \mathrm{D}$, a lens with a power of $+24.0+4.0 \times 0^{\circ}$ was custom-made to be implanted in the 10 -degree axis. Based on this (suboptimal) calculation for emmetropia, the residual refraction was estimated at $+3.0-2.5 \times 100^{\circ}$, suitable for spectacle correction.

The patient underwent an exchange of the Artisan aphakic IOL for an Artisan toric aphakic IOL through a $5.3 \mathrm{~mm}$ corneoscleral incision. After rotation, the lens was fixated in the 10-degree axis with the use of a disposable enclavation needle (Ophtec BV, Groningen, Netherlands). The wound was sutured with four interrupted 10 - 0 nylon sutures (Alcon, Fort Worth, Texas). The postoperative medical regimen has been described before. ${ }^{10}$

Ten months after the IOL exchange, the patient reported that her visual complaints had disappeared. The BCVA was 20/20 with a refraction of $+1.00-1.00 \times 120^{\circ}$. Topographic keratometry values were $34.0 \times 20^{\circ}$ and $26.9 \times 110^{\circ}$. The endothelial cell density was 1383 cells $/ \mathrm{mm}^{2}$; endothelial cell loss as compared to the preoperative ECD was 15.3\%. The intraocular pressure was $12 \mathrm{mmHg}$. Slit-lamp examination showed a clear and centered IOL (Fig. 2). 


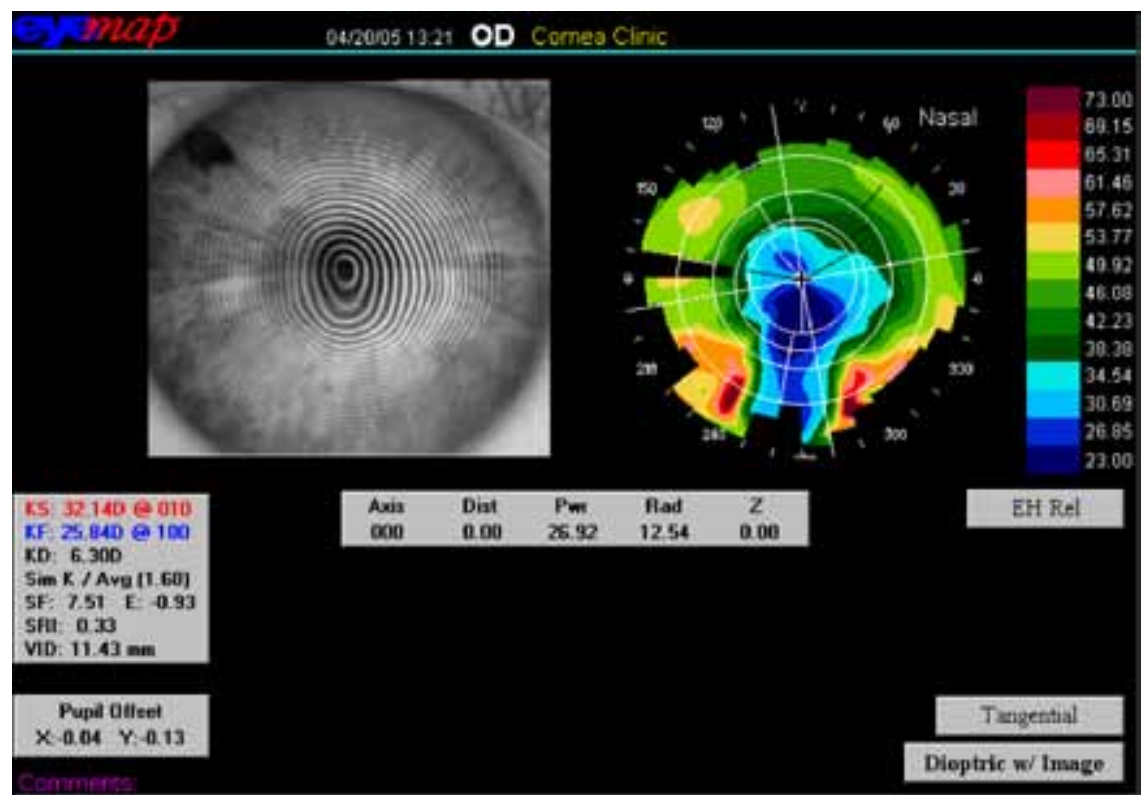

Figure 1. (Case 1) Corneal topography image before the Artisan toric aphakic intraocular lens implantation, demonstrating the large variability (approximately 23 to 38 diopters) in corneal powers in the $3-\mathrm{mm}$ zone.

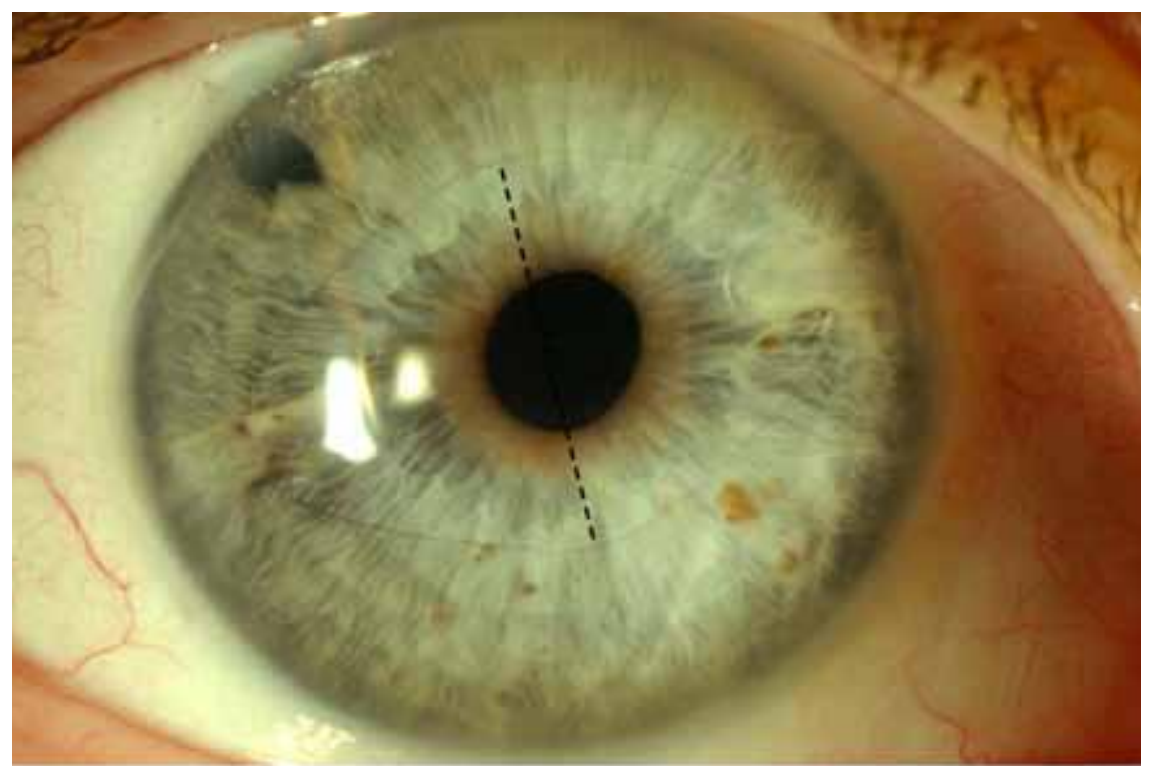

Figure 2. (Case 1) A slit-lamp photograph taken one month after the implantation of an Artisan toric aphakic intraocular lens for the correction of progressive hyperopia and astigmatism after cataract surgery in an eye that was previously treated with radial keratotomy. The lens was enclaved along the 10-degree axis (the perforated line marks the 90-degree meridian axis of the toric lens). 


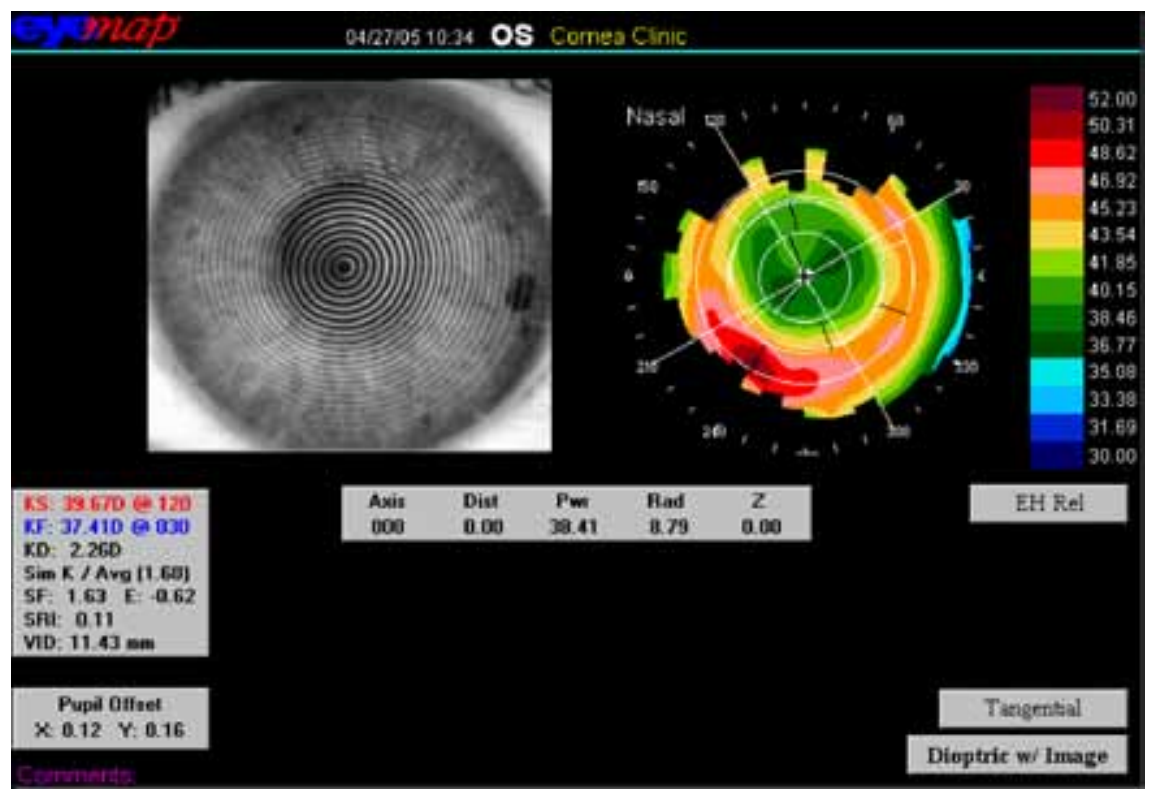

Figure 3. (Case 2, left eye) Corneal topography image before Artisan toric phakic intraocular lens implantation for the correction of residual myopia in an eye that was previously treated with 12 radial keratotomy incisions. The image shows a well-centered optical zone and a regular astigmatism.

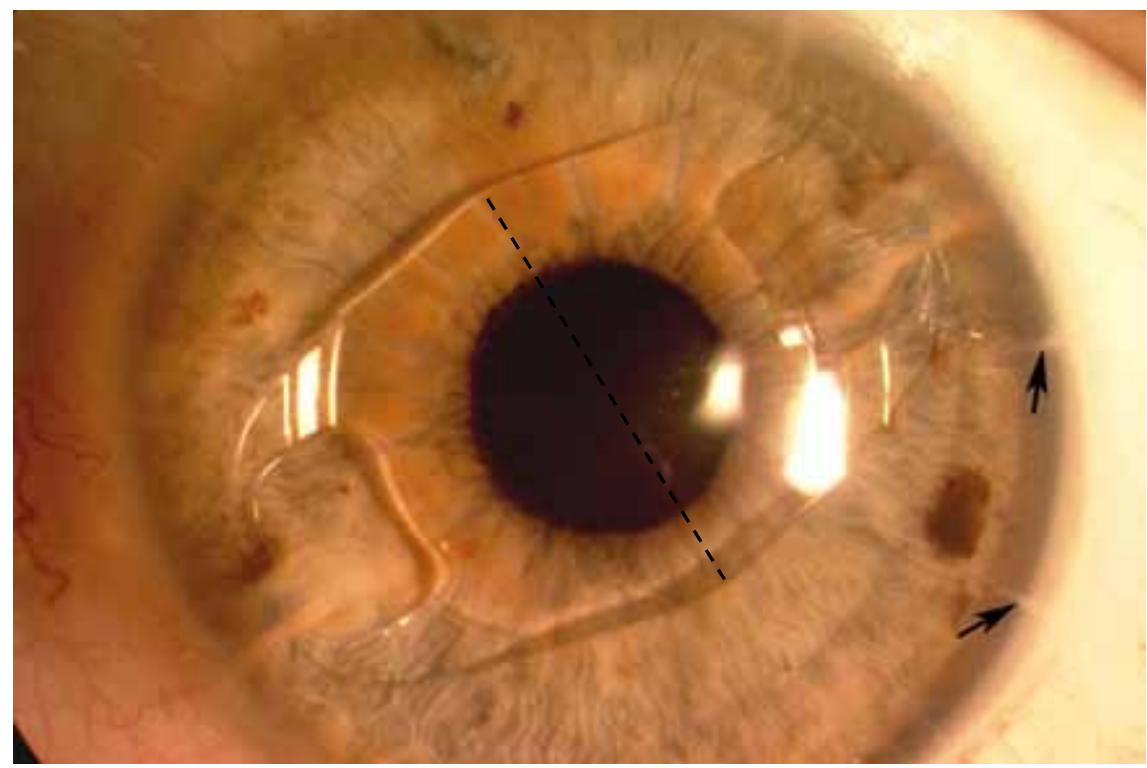

Figure 4. (Case 2, left eye) A slit-lamp photograph taken four months after the implantation of an Artisan toric phakic intraocular lens for the correction of residual myopia in an eye previously treated with radial keratotomy ( $\mathrm{RK}$ ) (the arrows indicate RK incisions). The lens was enclaved along the 40-degree axis (the perforated line marks the 90-degree meridian axis of the toric lens). 
Case 2

A 43-year-old female visited our university clinic in April 2005 for bilateral visual complaints. In 1995 she had undergone a bilateral RK procedure for the correction of a high myopia in both eyes. The pre-RK refraction was $-10.5-2.0$ $\mathrm{x} 142^{\circ}$ on the right and $-11.25-2.0 \times 1^{\circ}$ on the left. The procedure included 12 $\mathrm{RK}$ incisions in both eyes. Ten years after the $\mathrm{RK}$ procedure, the refraction was $-6.0-3.5 \times 135^{\circ}$ on the right and $-6.0-3.0 \times 45^{\circ}$ on the left. Due to contact lens intolerance, we scheduled her for a surgical correction of the residual myopia and astigmatism through the implantation of an Artisan toric phakic IOL implantation in both eyes.

The preoperative BCVA in the right eye was 20/30 with a refraction of -6.0 -3.5 $\mathrm{x} 130^{\circ}$ on the right and $20 / 30$ with a refraction of $-6.5-3.0 \times 40^{\circ}$ on the left. Topographic keratometry values were $40.0 \times 50^{\circ}$ and $37.4 \times 140^{\circ}$ on the right and $39.7 \times 120^{\circ}$ and $37.4 \times 30^{\circ}$ on the left (Fig. 3). The endothelial cell densities were 2117 cells $/ \mathrm{mm}^{2}$ and 1971 cells $/ \mathrm{mm}^{2}$, respectively. The ACDs were $3.28 \mathrm{~mm}$ and $3.25 \mathrm{~mm}$, respectively. The intraocular pressures were $14 \mathrm{mmHg}$.

IOL power calculations for postoperative emmetropia were performed using the corneal curvature, adjusted ACD, and manifest SE of the patient's subjective refractive error (van der Heijde formula) ${ }^{11}$ and resulted in an IOL power of -6.47 $-3.23 \times 130^{\circ}$ for the right eye and $-6.93-2.75 \times 40^{\circ}$ for the left eye. As mentioned above, it is usually preferred to position an Artisan IOL in a horizontal or an oblique angle, which resulted in an IOL with a dioptric power of $-6.5-3.0 \mathrm{x}$ $90^{\circ}$ which was fixated in the 40-degree axis in the right eye and an IOL with a dioptric power of $-7.0-2.5 \times 0^{\circ}$ which was fixated in the 40 -degree axis in the left eye.

We performed an implantation of an Artisan toric phakic IOL in the right eye, and two weeks later in the left eye. The surgical technique and postoperative medications were as described in the first case.

Four months after the IOL implantation, the patient reported that her visual complaints had disappeared and that she was very satisfied. The uncorrected visual acuity was 20/25 and 20/30, respectively. The BCVA was 20/25 with a refraction of $+0.25-1.0 \times 135^{\circ}$ and $20 / 20$ with a refraction of $-1.0 \times 40^{\circ}$, respectively. Topographic keratometry values were $40.6 \times 57^{\circ}$ and $37.4 \times 147^{\circ}$ on the right and $39.4 \times 130^{\circ}$ and $37.1 \times 40^{\circ}$ on the left (Fig. 4). The ECDs were 2120 cells $/ \mathrm{mm}^{2}$ and 1946 cells $/ \mathrm{mm}^{2}$, respectively. Endothelial cell loss as compared to the preoperative ECD was $-0.14 \%$ and $1.27 \%$ for the right and left eye, respectively. The intraocular pressures were $16 \mathrm{mmHg}$. Slit-lamp examination showed clear and centered IOLs (Fig. 4). 


\section{DISCUSSION}

Although RK procedures initially achieve satisfactory refractive outcome results, side effects are known to occur. Clinical studies show that the development of a hyperopic shift after RK is a common side effect that occurs with a frequency of $17 \%$ to $43 \%$ with an additional incidence of $1 \%$ to $2 \%$ each year. ${ }^{1,3,4,12-16}$ This is due to the long-term instability of the refraction which is related to the ongoing effect of the procedure and a possible insufficient corneal stability. ${ }^{12,17}$ The development of irregular astigmatism after RK can be induced by the intersection of the incisions with the visual axis or by the eccentricity of the optical zone. ${ }^{5}$

We have no adequate explanation why the topographical K-values for the calculation of the IOL powers led to such a favorable outcome in our first case. One explanation could be that among the variable corneal powers in the $3-\mathrm{mm}$ zone (Fig. 1), the selected K-value by chance was the most appropriate one. In the second case, it is probable that the $\mathrm{K}$-values regressed toward the corneal curvature parameters prior to the $\mathrm{RK}$, since it is unlikely that the K-values after RK (mean value 38.7 and $38.6 \mathrm{D}$, right and left eye) were comparable with the pre-RK refractions of -11.5 and $-12.50 \mathrm{D}$, right and left eye. Following this hypothesis, the topographically measured error might have been smaller.

Various techniques can be used to treat residual refractive error following RK. The correction of myopic astigmatism after RK by a contact lens may be useful, but may be complicated by intolerance. ${ }^{18}$ The lasso-string suture serves only as an immediate solution for symptomatic overcorrected hyperopic eyes after radial keratotomy, but seems to have a diminishing effect over time. ${ }^{19,20}$ Photorefractive keratectomy and laser in situ keratomileusis did not appear to be reasonable options because of the magnitude of the refractive error in both cases and the possible consequences for development of haze and flap complications. ${ }^{21-25}$ Clear lens extraction could be considered in our second case, but would not sufficiently treat her astigmatism and also has a higher risk for postoperative retinal detachment. ${ }^{26,27}$ The implantation of a (phakic) toric posterior chamber IOL could have been a suitable option in the second case. ${ }^{28,29}$ Since the spectacle BCVA after RK was $\geq 20 / 25$ in all eyes, indicating no significant visual loss from irregular astigmatism, penetrating keratoplasty $(\mathrm{PK})$ was no valuable option. The implantation of toric iris-fixated IOLs in normal virgin and post-PK eyes appears to be a safe and predictable method for the correction of high levels of astigmatism, with $63 \%$ to $73 \%$ of treated eyes within $\pm 0.50 \mathrm{D}$ of the predicted correction and a BCVA improvement in $65.7 \%$ to $70 \%$ of eyes. ${ }^{7-9,30}$ To our knowledge, the implantation of an Artisan toric lens in RK-eyes has not been described before and therefore the long-term visual stability and safety data are unknown. During the procedure we aimed to avoid wound dehiscence of the RK incisions by making a corneoscleral tunnel at a distance of $1.5 \mathrm{~mm}$ from the limbus.

The amount of endothelial cell loss after Artisan lens implantation in normal virgin eyes has been shown to vary and can be as high as $12 \% .{ }^{31-34}$ However, studies 
on endothelial cell loss in eyes that underwent Artisan toric lens implantation after PK showed a loss close to 30\% after 24 months, which suggests that corneal grafts are more susceptible to endothelial cell loss. As far as we know, there are no data in the literature of the long-term effects of the Artisan aphakic lens on the corneal endothelium., ${ }^{95}$ Our first case of implantation of the Artisan toric lens in an aphakic eye demonstrated an endothelial cell loss close to $14 \%$. We believe that this is an acceptable loss in this patient, considering her limited treatment options and her significant visual complaints. The second case of implantations of the Artisan toric lens in phakic eyes showed a low endothelial cell loss of $-0.14 \%$ and $1.27 \%$, respectively, which is in accordance with the literature.

In summary, our first case was successfully treated by the implantation of an Artisan toric aphakic IOL and the second case had a similar satisfactory outcome after the implantation of an Artisan toric PIOL. In RK-eyes, the removability option of the Artisan lens can be an important advantage, especially when dealing with potentially progressive refractive error changes after corneal refractive surgery. 


\section{REFERENCES}

1. Waring GO, 3rd, Lynn MJ, McDonnell PJ. Results of the prospective evaluation of radial keratotomy (PERK) study 10 years after surgery. Arch Ophthalmol 1994;112:1298-1308.

2. Kemp JR, Martinez CE, Klyce SD, et al. Diurnal fluctuations in corneal topography 10 years after radial keratotomy in the Prospective Evaluation of Radial Keratotomy Study. J Cataract Refract Surg 1999;25:904-910.

3. Deitz MR, Sanders DR, Raanan MG, DeLuca M. Long-term (5- to 12-year) followup of metal-blade radial keratotomy procedures. Arch Ophthalmol 1994;112:614-620.

4. Salz JJ, Salz JM, Salz M, Jones D. Ten years experience with a conservative approach to radial keratotomy. Refract Corneal Surg 1991;7:12-22.

5. McDonnell PJ, Caroline PJ, Salz J. Irregular astigmatism after radial and astigmatic keratotomy. Am J Ophthalmol 1989;107:42-46.

6. Alio JL, Mulet ME, Gutierrez R, Galal A. Artisan toric phakic intraocular lens for correction of astigmatism. J Refract Surg 2005;21:324-331.

7. Guell JL, Vazquez M, Malecaze F, et al. Artisan toric phakic intraocular lens for the correction of high astigmatism. Am J Ophthalmol 2003;136:442-447.

8. Dick HB, Alio J, Bianchetti M, et al. Toric phakic intraocular lens: European multicenter study. Ophthalmology 2003;110:150-162.

9. Tahzib NG, Cheng YY, Nuijts RM. Three-year follow-up analysis of Artisan toric lens implantation for correction of postkeratoplasty ametropia in phakic and pseudophakic eyes. Ophthalmology 2006;113:976-984.

10. Tahzib NG, Bootsma SJ, Eggink FA, Nuijts RM. Functional outcome and patient satisfaction after artisan phakic intraocular lens implantation for the correction of myopia. Am J Ophthalmol 2006;142:31-39.

11. van der Heijde GL, Fechner PU, Worst JG. [Optical consequences of implantation of a negative intraocular lens in myopic patients]. Klin Monatsbl Augenheilkd 1988;193:99-102.

12. Gimbel H, Sun R, Kaye GB. Refractive error in cataract surgery after previous refractive surgery. J Cataract Refract Surg 2000;26:142-144.

13. Koch DD, Liu JF, Hyde LL, Rock RL, Emery JM. Refractive complications of cataract surgery after radial keratotomy. Am J Ophthalmol 1989;108:676-682.

14. Lyle WA, Jin GJ. Intraocular lens power prediction in patients who undergo cataract surgery following previous radial keratotomy. Arch Ophthalmol 1997;115:457-461.

15. Packer M, Brown LK, Hoffman RS, Fine IH. Intraocular lens power calculation after incisional and thermal keratorefractive surgery. J Cataract Refract Surg 2004;30:1430-1434.

16. Seitz B, Langenbucher A. Intraocular lens power calculation in eyes after corneal refractive surgery. J Refract Surg 2000;16:349-361.

17. Hjortdal JO, Bohm A, Kohlhaas M, et al. Mechanical stability of the cornea after radial keratotomy and photorefractive keratectomy. J Refract Surg 1996;12:459-466. 
18. Alio JL, Belda JI, Artola A, Garcia-Lledo M, Osman A. Contact lens fitting to correct irregular astigmatism after corneal refractive surgery. J Cataract Refract Surg 2002;28:1750-1757.

19. Miyashiro MJ, Yee RW, Patel G, Karas Y, Grene RB. Lasso procedure to revise overcorrection with radial keratotomy. Am J Ophthalmol 1998;126:825-827.

20. Damiano RE, Forstot SL, Frank CJ, Kasen WB. Purse-string sutures for hyperopia following radial keratotomy. J Refract Surg 1998;14:408-413.

21. Lyle WA, Jin GJ. Laser in situ keratomileusis for consecutive hyperopia after myopic LASIK and radial keratotomy. J Cataract Refract Surg 2003;29:879-888.

22. Lipshitz I, Man O, Shemesh G, Lazar M, Loewenstein A. Laser in situ keratomileusis to correct hyperopic shift after radial keratotomy. J Cataract Refract Surg 2001;27:273-276.

23. Shah SB, Lingua RW, Kim CH, Peters NT. Laser in situ keratomileusis to correct residual myopia and astigmatism after radial keratotomy. J Cataract Refract Surg 2000;26:1152-1157.

24. Azar DT, Tuli S, Benson RA, Hardten DR. Photorefractive keratectomy for residual myopia after radial keratotomy. PRK After RK Study Group. J Cataract Refract Surg 1998;24:303-311.

25. Francesconi CM, Nose RA, Nose W. Hyperopic laser-assisted in situ keratomileusis for radial keratotomy induced hyperopia. Ophthalmology 2002;109:602-605.

26. Muraine M, Siahmed K, Retout A, Brasseur G. [Phacoemulsification following radial keratotomy. Topographic and refractive analysis concerning an 18-month period (apropos of a case)]. J Fr Ophtalmol 2000;23:265-269.

27. Colin J, Robinet A, Cochener B. Retinal detachment after clear lens extraction for high myopia: seven-year follow-up. Ophthalmology 1999;106:2281-2284; discussion 2285.

28. Pineda-Fernandez A, Jaramillo J, Vargas J, Jaramillo M, Jaramillo J, Galindez A. Phakic posterior chamber intraocular lens for high myopia. J Cataract Refract Surg 2004;30:2277-2283.

29. Sanders DR, Brown DC, Martin RG, Shepherd J, Deitz MR, DeLuca M. Implantable contact lens for moderate to high myopia: phase 1 FDA clinical study with 6 month follow-up. J Cataract Refract Surg 1998;24:607-611.

30. Tehrani M, Dick HB. Iris-fixated toric phakic intraocular lens: Three-year follow-up. J Cataract Refract Surg 2006;32:1301-1306.

31. Pop M, Payette Y. Initial results of endothelial cell counts after Artisan lens for phakic eyes: an evaluation of the United States Food and Drug Administration Ophtec Study. Ophthalmology 2004;111:309-317.

32. Budo C, Hessloehl JC, Izak M, et al. Multicenter study of the Artisan phakic intraocular lens. J Cataract Refract Surg 2000;26:1163-1171.

33. Menezo JL, Cisneros AL, Rodriguez-Salvador V. Endothelial study of iris-claw phakic lens: four year follow-up. J Cataract Refract Surg 1998;24:1039-1049. 
34. Budo C, Bartels MC, van Rij G. Implantation of Artisan toric phakic intraocular lenses for the correction of astigmatism and spherical errors in patients with keratoconus. J Refract Surg 2005;21:218-222.

35. Kanellopoulos AJ. Penetrating keratoplasty and Artisan iris-fixated intraocular lens implantation in the management of aphakic bullous keratopathy. Cornea 2004;23:220-224. 


\section{Recurrent intraocular inflammation after Artiflex phakic intraocular lens implantation for the correction of high myopia}

Tahzib NG, Eggink FAGJ, Frederik PM, Nuijts RMMA.

J Cataract Refract Surg. 2006 Aug;32(8):1388-91. 


\section{ABSTRACT}

We describe a 54-year old man who developed a severe cell deposition one week after the implantation of a foldable Artiflex phakic intraocular lens (PIOL) with a silicone optic and polymethyl methacrylate (PMMA) haptics in the left eye for the correction of high myopia. Nine months after the lens implantation, many cell deposits remained visible on the posterior surface of the lens, causing him to suffer from severe glare, especially during daylight conditions. We explanted the Artiflex PIOL and exchanged it for a PMMA Artisan PIOL.

One month after the lens exchange, the uncorrected visual acuity was 20/20 and the patients' glare complaints had disappeared. Slit-lamp examination showed no signs of inflammation in the anterior segment or any cell deposits on the PMMA Artisan PIOL. Scanning electron microscopy demonstrated multiple cell deposits on the explanted Artiflex PIOL. 


\section{INTRODUCTION}

The Artiflex lens is an iris-fixated phakic intraocular lens (PIOL) for the correction of myopia and has not been described before. The Artiflex PIOL has a convex-concave silicone optic with a 6-mm flexible optical zone (for intraocular lens powers from -2.0 up to $-14.50 \mathrm{D})$ with polymethyl methacrylate (PMMA) rigid haptics and is available in $0.50 \mathrm{D}$ steps (Ophtec B.V., Groningen, the Netherlands). The Artiflex design differs from the PMMA Artisan design in that the vault between the haptic-optic junction and the iris plane is $0.13 \mathrm{~mm}$ in the Artiflex PIOL as compared to $0.20 \mathrm{~mm}$ in the PMMA Artisan PIOL. The foldable Artiflex PIOL may offer an advantage compared to the PMMA Artisan PIOL by its insertion through a $3.4 \mathrm{~mm}$ incision as compared to a $6.3 \mathrm{~mm}$ incision for the PMMA Artisan PIOL. The smaller incision may decrease surgically induced astigmatism and postoperative inflammation.

We report a case of severe adhesion of cell deposits to the posterior surface of an Artiflex lens and the lens haptics, which was treated by the exchange of the Artiflex PIOL for an Artisan PIOL, nine months after the initial implantation.

\section{Case report}

A 54-year old male was scheduled for Artiflex PIOL implantation in both eyes for the correction of high myopia. The preoperative best corrected visual acuity (BCVA) in the right and left eye was $25 / 20$ and 20/20 with a refraction of -9.25 $\mathrm{D}$ and $-9.5 \mathrm{D}-0.5 \times 0^{\circ}$, respectively. The intraocular pressures were $16 \mathrm{mmHg}$ in both eyes. The anterior chamber depths (IOL Master, Carl Zeiss Meditec, Germany) were $3.30 \mathrm{~mm}$ and $3.22 \mathrm{~mm}$ in the right and left eye. The endothelial cell counts were 2697 cells $/ \mathrm{mm}^{2}$ and 2842 cells $/ \mathrm{mm}^{2}$, respectively. The scotopic pupil diameter measured with the Colvard pupillometer (Oasis Medical, Glendora, CA) under dim light conditions was $6.0 \mathrm{~mm}$ in both eyes.

The surgical procedure consisted of a two-plane $3.4 \mathrm{~mm}$ limbal incision centered at 12 -o'clock. Two stab incisions were performed at 2- and 10 o'clock and directed towards the enclavation sites. After an intracameral injection of acetylcholine, the lens was introduced beneath an ophthalmic viscoelastic device (Healon GV ${ }^{\circledR}$, Pharmacia, Uppsala, Sweden) and fixated with custom-designed instruments (Ophtec B.V., Groningen, the Netherlands). A slit iridotomy was performed at 12 o'clock to avoid pupillary block glaucoma. The wound was sutured with one 10-0 nylon suture (Alcon, Fort Worth, Texas). At the end of the surgical procedure, a $1.0 \mathrm{cc}$ subconjunctival steroid injection (Celestone ${ }^{\circledR}$, Schering-Plough, Kenilworth, New Jersey) was given. Postoperatively, topical tobramycin 0.3\% combined with dexamethasone $0.1 \%$ (Tobradex ${ }^{\circledR}$, Alcon, Couvreur, Belgium) and ketorolactrometamol $0.5 \%$ (Acular ${ }^{\circledR}$, Westport Co., Mayo, Ireland) were used four times daily for 3 weeks in a tapered regimen and three times daily for 1 week, respectively. 
The procedure in the right eye whereby an Artiflex PIOL with a power of -9.5 $\mathrm{D}$ was implanted, was uneventful and 1 month postoperatively the uncorrected visual acuity (UCVA) and BCVA were 20/20 and 25/20 with a refraction of plano $-0.5 \times 145^{\circ}$. Three months postoperatively, the UCVA was 20/20 with a $1+$ cell reaction in the anterior chamber and cell and pigment deposits on the posterior surface of the PIOL. The intraocular pressure was $20 \mathrm{mmHg}$. A short course of prednisolone acetate (Predforte ${ }^{\circledR}$, Allergan, Co. Mayo, Ireland) q.i.d. and timolol 0.5\% 2 times daily eye drops was initiated and the inflammatory reaction subsequently subsided. Twelve months postoperatively, UCVA and BCVA in the right eye were $20 / 20$ and $25 / 20$ with a refraction of +0.25 D. There were no inflammatory signs in the anterior chamber or any visible cell deposits on the PIOL. The endothelial cell density was 2746 cells $/ \mathrm{mm}^{2}$.

Six weeks after the uncomplicated surgical procedure in the right eye, the left eye underwent an uneventful implantation of an Artiflex PIOL with a power of -10.0 D. There was no difference in the surgical technique or in the degree of iris manipulation between the procedures on the right and left eye. One week after the procedure, the patient complained of starbursts which he experienced in bright daylight conditions. Slit-lamp examination of the left eye demonstrated a severe cell deposition (>15 clusters of cells) and pigment on the posterior surface of the PIOL. The intraocular pressure was $24 \mathrm{mmHg}$. Prednisolone acetate (Predforte ${ }^{\circledR}$, Allergan, Co. Mayo, Ireland) eye drops were given at a dose of 6 times daily and eye-pressure lowering eye drops were applied once a day. Six months postoperatively, after slow tapering of the steroid drops, a recurrence of large cell deposits was seen on the posterior surface of the PIOL and on the lens haptics. Increasing the dosage of topical steroids resulted in a subsequent decrease of the cell deposits on the PIOL. Nine months after surgery however, after renewed tapering of the steroid eye drop regimen, slit-lamp examination again demonstrated many large cell and pigment deposits on the posterior surface of the PIOL (Figure 1). The BCVA decreased to $20 / 25$ with a refraction of +0.5 $-1.0 \times 170^{\circ}$. The patient reported persistent and severe glare complaints during daylight conditions. The endothelial cell count was 2457 cells $/ \mathrm{mm}^{2}$.

An uneventful explantation of the left Artiflex PIOL with a subsequent exchange for a PMMA Artisan PIOL was performed. During surgery, aqueous humor was obtained for inflammatory cell analysis and the explanted Artiflex lens was fixed for scanning electron microscopy.

Three months after the lens exchange, the UCVA of the left eye was 20/20 and the intraocular pressure was $16 \mathrm{mmHg}$. Slit-lamp examination did not show any cell deposits on the PMMA Artisan PIOL and the patient no longer complained of glare.

Scanning electron microscopy demonstrated multiple cell deposits with a pseudopodia-like pattern on the posterior surface of the PIOL and on the haptics (Figure 2). Inflammatory cell analysis with a CD45 and a stem-cell marker did not demonstrate specific staining for lymphocytes or granulocytes. Analysis with 
a CD68 marker did not demonstrate the presence of macrophages, however since only one marker was used for analysis, it is not sure whether macrophages were present or not.

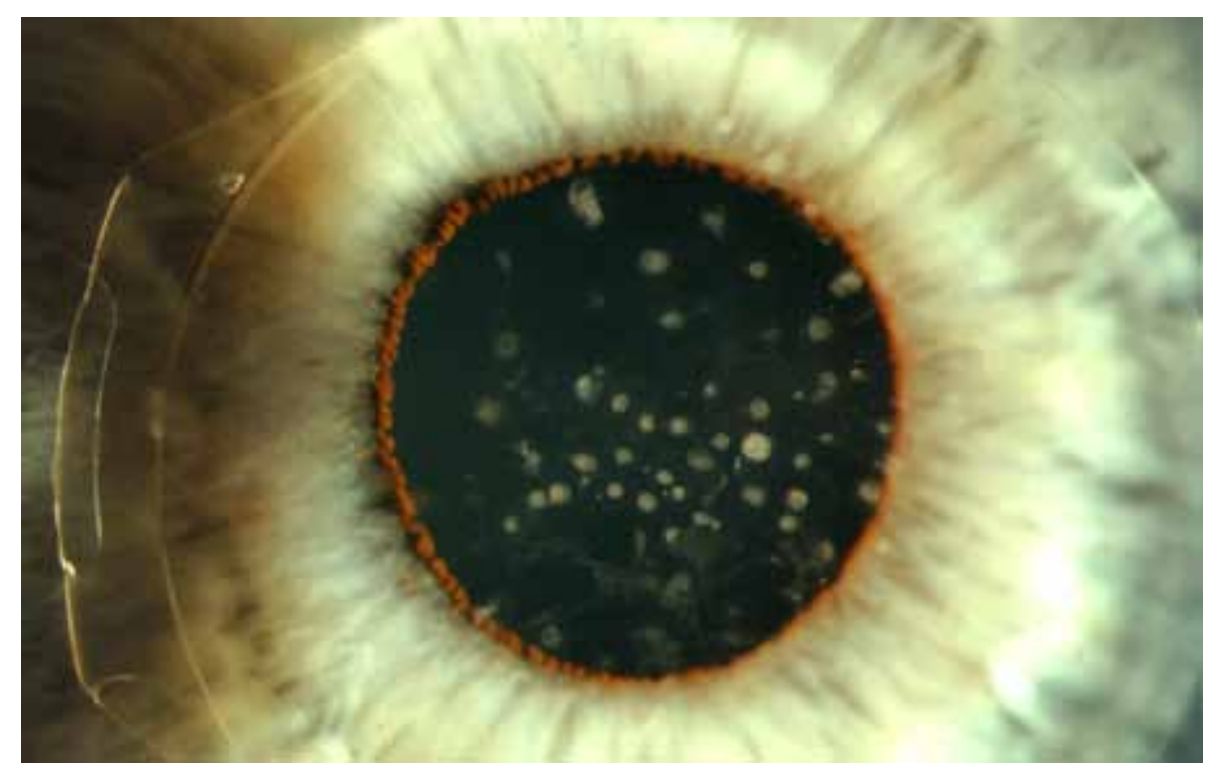

Figure 1. A slit-lamp photograph taken nine months after the implantation of the iris-fixated silicone Artiflex phakic intraocular lens. The photograph demonstrates the many large cell and pigment deposits, which are mainly dispersed in the central zone on the posterior surface of the lens. 

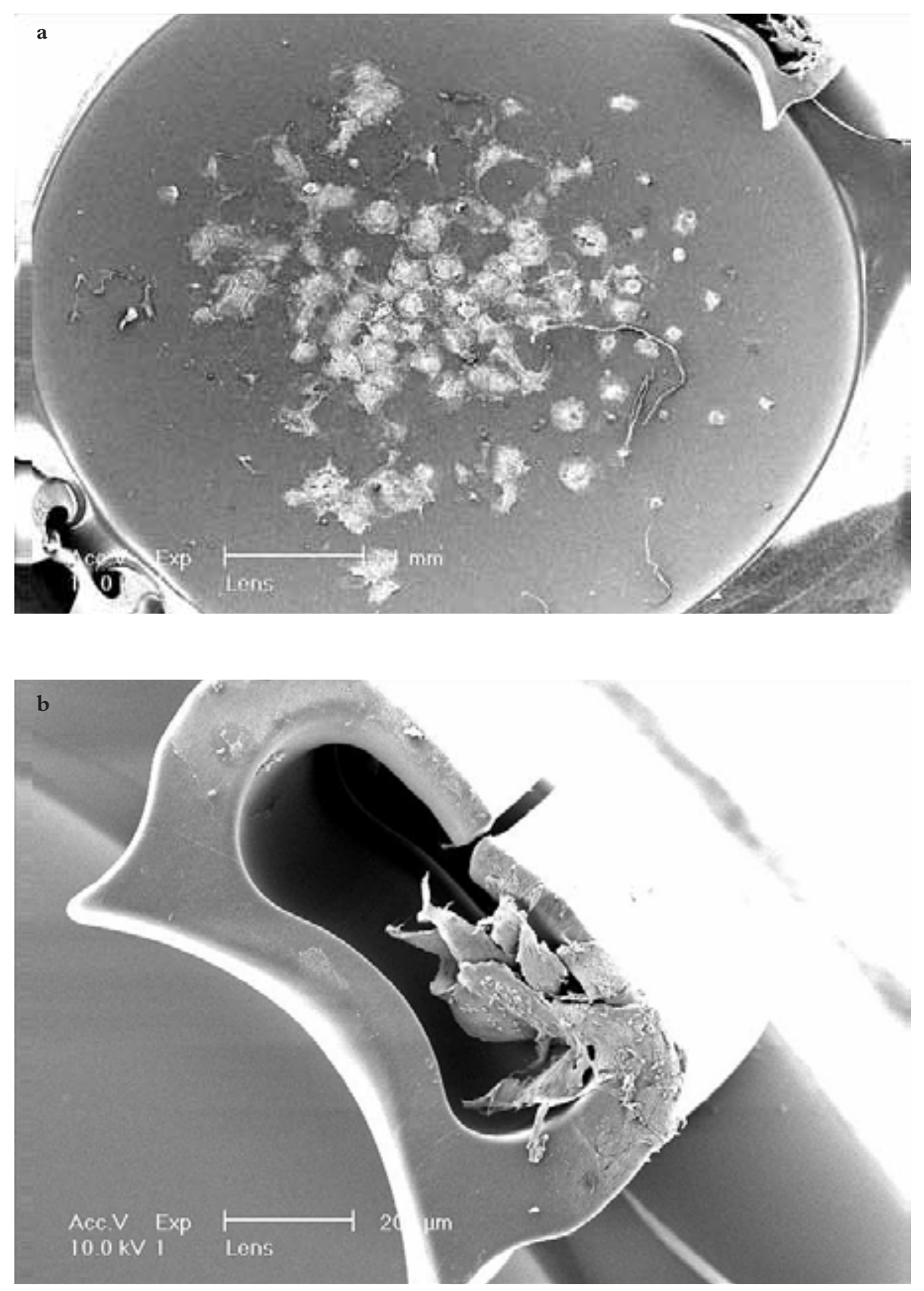

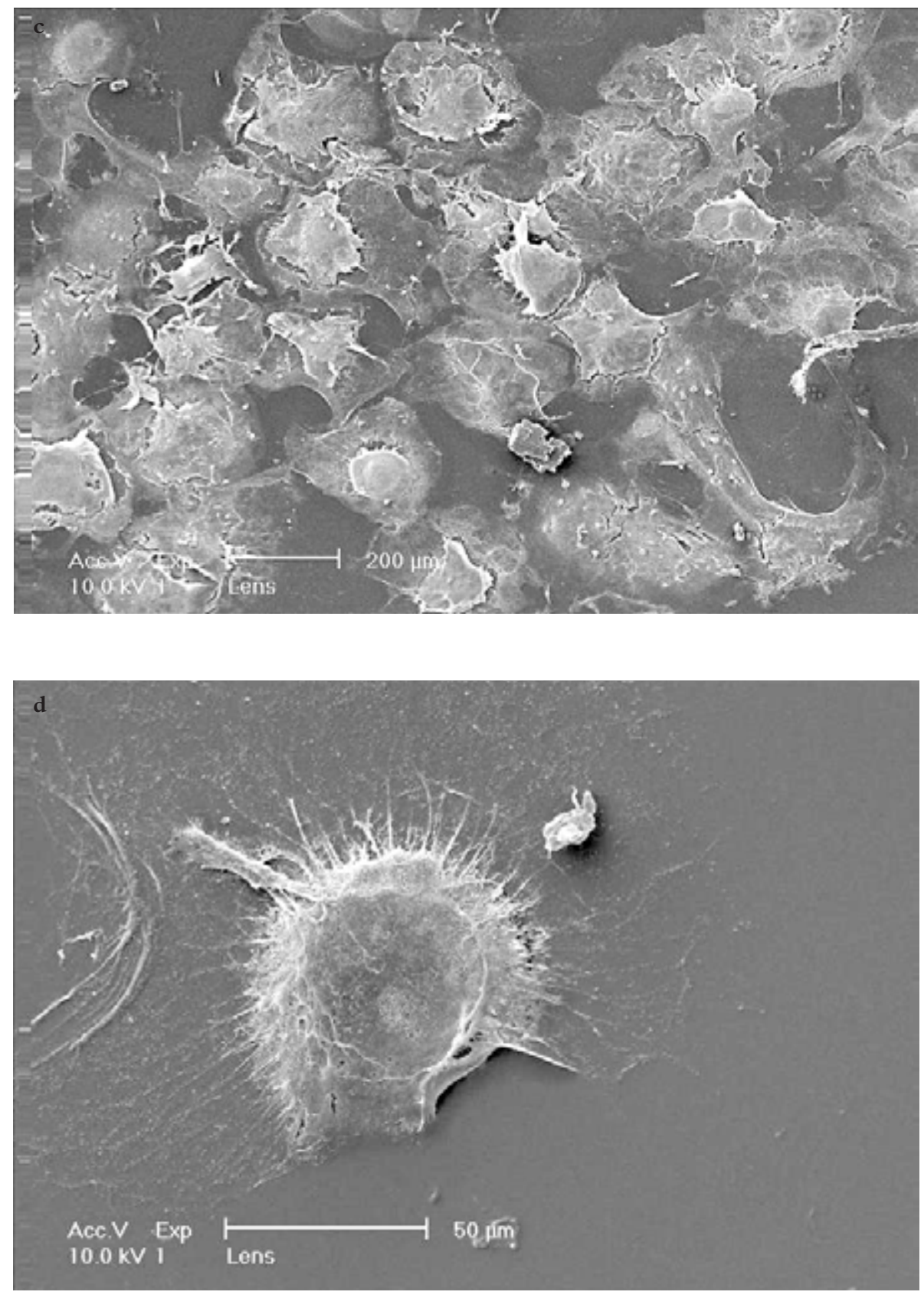

Figure 2. Scanning electron microscopy images illustrating an overview of the multiple large cell deposits on the posterior surface of the lens (a), demonstrating the finding of a very large accumulation of cell deposits at the junction of the silicone optic with the polymethyl methacrylate haptics (b), and demonstrating the pseudopodia-like pattern of the cells (c and d). 

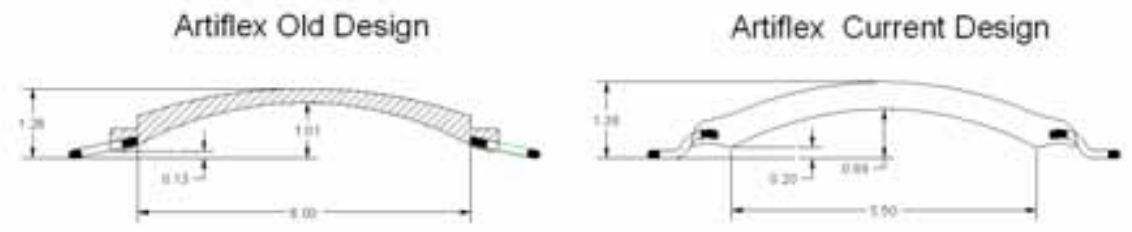

Figure 3. This drawing with cross-sections of the old and the new design of the Artiflex phakic intraocular lens illustrates that the new lens design is made up of an increased vault of $0.20 \mathrm{~mm}$ (compared to $0.13 \mathrm{~mm}$ in the old design) between the optic-haptic junction and the iris plane.

\section{DISCUSSION}

The advantages of a phakic intraocular lens (PIOL) for the correction of moderate to high myopia are the potential reversibility, safety, predictability and stability of the correction. Clinical studies have demonstrated that the implantation of the recently FDA approved polymethyl methacrylate (PMMA) Artisan PIOL for the correction of myopia is a safe, effective and predictable procedure. ${ }^{1-6}$ The foldable Artiflex iris-fixated PIOL is a new development in the area of lenticular refractive surgery techniques for the correction of myopia and is currently being evaluated in a European multicenter study. One of the major advantages of the foldable Artiflex lens over the PMMA Artisan lens is the insertion through a smaller incision of $3.4 \mathrm{~mm}$, which may reduce the surgically induced astigmatism and may shorten the visual recovery period after surgery. No reports on the safety or efficacy of the recently introduced Artiflex foldable PIOL are currently available in the literature, except for a case report on the correction of aphakia after penetrating ocular injury. ${ }^{7}$

Our case report demonstrates recurrent anterior segment inflammation with subsequent cell and pigment deposits on the posterior surface of the Artiflex PIOL. The pathogenesis of this reaction is currently unknown, but we hypothesize that the decreased vault between the haptic-optic junction of the lens and the iris plane may result in mechanical irritation of iris tissue during pupillary constriction and dilation. This may trigger a foreign-body respons and lead to breakdown of the blood-aqueous barrier with subsequent cell adhesions to the lens. Our hypothesis is supported by the finding that the largest accumulation of cell deposits occurred at the junction of the optic with the haptics. It is unclear whether the biocompatibility of the silicone material which has been used for the manufacturing of foldable posterior chamber lenses throughout many years by the same company without any adverse sequelae, plays a role in addition to 
the mechanical hypothesis. Various reports have described a decreased capsular or uveal biocompatibility of silicone lenses after cataract surgery in patients with uveitis or diabetes who are at risk for increased wound healing and inflammatory reactions after surgery. ${ }^{8} 9$ Two recent studies have suggested that pigment dispersion and subsequent inflammatory reaction after the implantion of Artisan PIOLs may be caused by abnormal pressure on the iris, which can become sandwiched between the crystalline lens and the PIOL, especially in hyperopic eyes. ${ }^{10,11}$ After the exchange of the Artiflex PIOL for the Artisan PIOL, which has a larger vault between the optic-haptic junction and the iris plane, the inflammatory reaction disappeared and no further cell adhesion was noted.

In conclusion, we believe that further improvements in the design of the Artiflex PIOL are needed to achieve the similar safety profile of its precursor, the PMMA Artisan PIOL, which has been used for many years with excellent safety and efficacy results. Recently, the company redesigned the Artiflex PIOL and increased the vault between the optic-haptic junction and the iris plane to $0.20 \mathrm{~mm}$ (Figure 3). Further study is needed to evaluate whether this will prevent accumulation of cell and pigment deposits on the Artiflex PIOL. 


\section{REFERENCES}

1. Maloney RK, Nguyen LH, John ME. Artisan phakic intraocular lens for myopia:shortterm results of a prospective, multicenter study. Ophthalmology 2002; 109:1631-41.

2. Malecaze FJ, Hulin H, Bierer P, et al. A randomized paired eye comparison of two techniques for treating moderately high myopia: LASIK and artisan phakic lens. Ophthalmology 2002; 109:1622-30.

3. Pop M, Payette Y. Initial results of endothelial cell counts after Artisan lens for phakic eyes: an evaluation of the United States Food and Drug Administration Ophtec Study. Ophthalmology 2004; 111:309-17.

4. El Danasoury MA, El Maghraby A, Gamali TO. Comparison of iris-fixed Artisan lens implantation with excimer laser in situ keratomileusis in correcting myopia between -9.00 and -19.50 diopters: a randomized study. Ophthalmology 2002; 109:955-64.

5. Budo C, Hessloehl JC, Izak M, et al. Multicenter study of the Artisan phakic intraocular lens. J Cataract Refract Surg 2000; 26:1163-71.

6. Worst JG, van der Veen G, Los LI. Refractive surgery for high myopia. The WorstFechner biconcave iris claw lens. Doc Ophthalmol 1990; 75:335-41.

7. Guell JL, Manero F. Artiflex (foldable iris claw IOL) secondary implantation for correction of aphakia after penetrating ocular injury. J Refract Surg 2004; 20:282-3.

8. Alio JL, Chipont E, BenEzra D, Fakhry MA. Comparative performance of intraocular lenses in eyes with cataract and uveitis. J Cataract Refract Surg 2002; 28:2096-108.

9. Abela-Formanek C, Amon M, Schauersberger J, Kruger A, Nepp J, Schild G. Results of hydrophilic acrylic, hydrophobic acrylic, and silicone intraocular lenses in uveitic eyes with cataract: comparison to a control group. J Cataract Refract Surg 2002; 28:1141-52.

10. Alio JL, Mulet ME, Shalaby AM. Artisan phakic iris claw intraocular lens for high primary and secondary hyperopia. J Refract Surg 2002; 18:697-707.

11. Baikoff G, Bourgeon G, Jodai HJ, Fontaine A, Lellis FV, Trinquet L. Pigment dispersion and Artisan phakic intraocular lenses: crystalline lens rise as a safety criterion. J Cataract Refract Surg 2005; 31:674-80. 


\section{Higher order aberrations in iris-fixated rigid and foldable phakic intraocular lenses}

Tahzib NG; MacRae SM, Yoon G, Berendschot TTJM, Eggink FAGJ, Hendrikse F, Nuijts RMMA.

J Cataract Refract Surg. In Press. 


\section{ABSTRACT}

Purpose: To evaluate higher order aberrations (HOA) after implantation of a foldable Artiflex phakic intraocular lens (PIOL).

Design: Retrospective comparative case-series.

Methods: Twenty-seven eyes of 14 patients who underwent Artiflex PIOL implantation were analyzed and compared to 22 eyes of 13 patients after Artisan PIOL implantation. Refractive data, pupil size, lens decentration and HOA values were recorded. Laboratory analysis was performed on both lenses. Follow-up was 1 year.

Results: In the Artiflex group, the mean spherical equivalent (SE) changed from $-9.95 \pm$ 1.43 diopters (D) (-6.75 to $-12.13 \mathrm{D})$ to $-0.30 \pm 0.53 \mathrm{D}$ (-1.94 to $0.56 \mathrm{D})$. Postoperatively, trefoil-y increased (increase factor 1.73) and spherical aberration decreased (increase factor 0.55 ). The mean decentration value was $0.24 \pm 0.12 \mathrm{~mm}$, with $96.3 \%$ demonstrating a decentration value $<0.5 \mathrm{~mm}$. There was a significant correlation between lens decentration and postoperative spherical aberration and coma-y. In the Artisan group, the mean SE changed from $-9.90 \pm 2.74 \mathrm{D}(-4.0$ to $-14.50 \mathrm{D})$ to $-0.20 \pm 0.42 \mathrm{D}(-0.75$ to $0.50 \mathrm{D})$. Postoperatively, trefoil-y and spherical aberration both increased (increase factors 3.32 and 6.84, respectively). Laboratory analysis confirmed the negative spherical aberration profile of the Artiflex PIOL and the positive spherical aberration profile of the Artisan PIOL.

Conclusion: Artiflex implantation induced a decrease in spherical aberration, while Artisan implantation induced an increase in spherical aberration. Trefoil-y increased in both groups. These changes might be explained by incision size differences in relation to trefoil, and differences in optic design in relation to spherical aberration. 


\section{INTRODUCTION}

Refractive surgery techniques have the goal of correcting the spherical and cylindrical refractive error in patients with visual complaints and who have the desire to be independent of spectacles and contact lenses.

We now know that naturally-occurring and surgically-induced optical abnormalities exist, which are also referred to as optical aberrations. Optical aberrations include lower and higher order aberrations (HOA). HOA (also referred to as irregular astigmatism) may influence postoperative visual outcome and patient satisfaction and need to be included in the preoperative evaluation and selection of refractive surgery candidates. ${ }^{1-3}$ The literature contains several clinical reports that have studied changes in HOA after refractive surgery for the correction of myopia, particularly after myopic laser in situ keratomileusis (LASIK) and photorefractive keratectomy (PRK). ${ }^{4-13}$ One study reported that the amount of achieved correction correlated with changes in ocular HOA. ${ }^{4}$ Another report demonstrated that total HOA increased by factor 1.53 and that spherical aberration increased by factor $1.6 .^{6}$

The excellent levels of efficacy, predictability, and safety of the Artisan phakic intraocular lens (PIOL) for the correction of moderate to high myopia, have been confirmed by several clinical reports. ${ }^{14-24}$ The recently designed Artiflex lens is an iris-fixated PIOL which can be implanted for the correction of myopia ${ }^{25}$; the lens is currently under clinical investigation in Europe. To our knowledge, only a few case reports ${ }^{26,27}$ and two clinical studies have so far evaluated the clinical and refractive results of this new iris-fixated PIOL model for the correction of myopia. ${ }^{28,29}$ The Artiflex lens has a convex-concave silicone optic with a 6-mm flexible optical zone (for intraocular lens powers from -2.0 up to -14.50 D) with polymethyl methacrylate (PMMA) rigid haptics. In its early design, the vault between the haptic-optic junction and the iris plane of the Artiflex PIOL design was $0.13 \mathrm{~mm}$ as compared to $0.20 \mathrm{~mm}$ in the PMMA Artisan PIOL was. Recently, the company redesigned the Artiflex lens and increased the vault between the optic-haptic junction and the iris plane to $0.20 \mathrm{~mm}$. The foldable Artiflex PIOL may offer an advantage compared to the PMMA Artisan PIOL by its insertion through a $3.4 \mathrm{~mm}$ incision as compared to a $6.3 \mathrm{~mm}$ incision for the PMMA Artisan PIOL. The smaller incision has advantages in that it leads to quicker rehabilitation and less trauma and postoperative inflammation.

The purpose of this study was to evaluate changes in HOA after Artiflex PIOL implantation and to compare these to a matched group of patients who had undergone Artisan PIOL implantation for the correction of a similar level of myopia. 


\section{METHODS}

Patient population and study design

The Artiflex patient group consisted of 27 eyes of 14 patients who had undergone Artiflex PIOL implantation for the correction of myopia. The Artisan group consisted of 22 eyes of 13 patients who had undergone Artisan PIOL implantation for the correction of myopia.

Comparisons of pre- and postoperative clinical data were made for all eyes. Investigational review board approval was obtained from the Academic Hospital Maastricht.

\section{Inclusion criteria}

Inclusion criteria were identical for both patient groups and were: a stable refraction during the previous 2 years, a preoperative spectacle corrected visual acuity $\geq 20 / 50$; an anterior chamber depth of $3.0 \mathrm{~mm}$ or more (IOL Master, Carl Zeiss AG, Germany); an endothelial cell density (ECD) count of 2000 cells $/ \mathrm{mm}^{2}$ or more (Noncon ROBO Pachy SP-9000, Konan Medical Inc, Tokyo, Japan), a normal pupil and iris configuration; no history of glaucoma, no pre-existent corneal, lenticular or retinal pathology likely to alter vision and no history of chronic or recurrent uveitis.

\section{Clinical evaluation}

Pre- and postoperatively, subjective and objective refraction was determined by measurement of the Snellen uncorrected (UCVA) and best-corrected (BCVA) visual acuity. Slit-lamp microscopy, corneal topography (Alcon Eyemap EH-290, Alcon, Fort Worth, TX), and intraocular pressure measurement with Goldmann applanation tonometry and dilated fundus examinations were performed.

\section{Pupil size and PIOL decentration}

The mesopic-low (with an illumination level of 0.4 lux) pupil size was measured with a digital infrared pupillometer (P2000 SA pupillometer, Procyon Instruments Ltd., London, UK). This device has been described before. ${ }^{14,} 30$ The amount of PIOL decentration was determined by measuring the deviation of the center of the PIOL from the center of the pupil using the digital photography mode within the pupillometer. 


\section{Wavefront measurements}

Wavefront measurements were performed with a Hartmann-Shack wavefront sensor (Zywave aberrometer, software version 3.21, Bausch \& Lomb-Technolas, Munich, Germany) with an analysis pupil diameter of $6 \mathrm{~mm}$. The aberrations analyzed in this comparative study are classified in terms of HOA, trefoil-x $\left(Z_{3}{ }^{3}\right)$, trefoil-y $\left(Z_{3}{ }^{-3}\right)$, coma-x $\left(Z_{3}{ }^{1}\right)$, vertical coma-y $\left(Z_{3}{ }^{-1}\right)$, and spherical aberration $\left(Z_{4}{ }^{0}\right)$. All values are in OSA order and sign convention. The Zywave aberrometer and technique of Zywave measurements have been described before. ${ }^{14,31-33}$

\section{Laboratory $\mathrm{HOA}$ analysis}

To study the changes in HOA for each lens type, a laboratory investigation was performed at the Center for Visual Science at the University of Rochester. For this purpose, two Artiflex and two Artisan myopic lenses with a lens power of $-9 \mathrm{D}$ and two Artiflex and two Artisan myopic lenses with a lens power of $-12 \mathrm{D}$ were mounted vertically in a wet cell and measured with a high resolution Shack-Hartmann type wavefront sensor developed at the Center for Visual Science at the University of Rochester, to measure the aberration profile of these ophthalmic lenses. Collimated light $(632.8 \mathrm{~nm})$ was directed at the lens and aberrations to the $10^{\text {th }}$ order were collected. The spacing between the lenslets was $133.33 \mu \mathrm{m}$ with a focal length of $3.75 \mathrm{~mm}$. There are 745 wavefront sensing spots in a $6 \mathrm{~mm}$ pupil which are sufficient to reliably calculate up to $10^{\text {th }}$ order Zernike aberrations. HOA were measured over a $6 \mathrm{~mm}$ pupil size, and were renormalized to $5 \mathrm{~mm}$ and $4 \mathrm{~mm}$ diameters (with decentrations up to $200 \mu \mathrm{m}$ ). Spherical aberration corresponds with Zernike mode number $12\left(\mathrm{Z}_{4}{ }^{0}\right)$.

\section{Surgical procedure}

All treatments were performed by a single surgeon (R.N.) at the Academic Center for Refractive Surgery, University Eye Clinic of Maastricht.

The Artiflex lens is an iris-fixated PIOL for the correction of myopia. It is a threepiece lens consisting of a 6 - $\mathrm{mm}$ flexible optic made from ultraviolet absorbing polysiloxane and rigid haptics made from compression molded Perspex CQ UV PMMA (for intraocular lens powers from -2.0 up to $-14.50 \mathrm{D}$ ) and is available in 0.50 D steps (Ophtec B.V., Groningen, the Netherlands). The Artisan iris claw-fixated PIOL has a convex-concave PMMA optic with either a 6-mm (for intraocular lens powers up to $-15.5 \mathrm{D}$ ) or a $5-\mathrm{mm}$ (for intraocular lens powers from $-16.0 \mathrm{D}$ up to $-24.0 \mathrm{D}$ ) and is available in $0.50 \mathrm{D}$ steps (Ophtec B.V., Groningen, the Netherlands) (Fig. 1).

The Artiflex design that was analysed in this study differed from the Artisan design in that the vault between the haptic-optic junction and the iris plane was $0.13 \mathrm{~mm}$ in the Artiflex PIOL as compared to $0.20 \mathrm{~mm}$ in the PMMA Artisan 

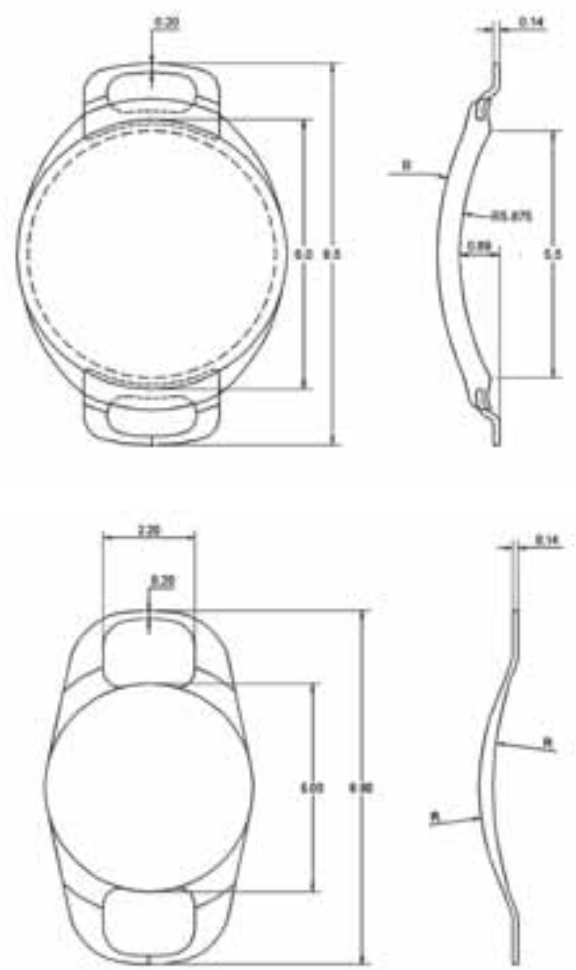

Figure 1. Schematic photograph of the Artiflex (above) and Artisan (below) Phakic Intraocular Lens design

PIOL. The incision used for the foldable Artiflex PIOL is $3.4 \mathrm{~mm}$ as compared to the $6.3 \mathrm{~mm}$ incision required for the PMMA Artisan PIOL. Recently, the company redesigned the Artiflex PIOL and increased the vault between the optic-haptic junction and the iris plane to $0.20 \mathrm{~mm}$, thereby aiming to prevent accumulation of cell and pigment deposits on the Artiflex PIOL. ${ }^{27}$

The dioptric power of the lens was calculated with the use of the refractive error, refractive cylinder power, anterior chamber depth, and topographically derived keratometric dioptric values (EyeMap EH-290, Alcon, Forth Worth, Tx), which were inserted into the Van der Heijde formula. ${ }^{17}$ The power of the lens was chosen to obtain emmetropia. When the emmetropic lens was not available, the power of the lens was estimated for a slight residual myopia.

Surgery was performed under general anaesthesia. Important differences between the Artiflex and Artisan surgical procedures are the incision size, which is 3.4 $\mathrm{mm}$ for the Artiflex lens and $6.3 \mathrm{~mm}$ for the Artisan lens. Also, after the Artiflex implantation, the wound is sutured with one 10-0 nylon suture (Alcon, Fort Worth, Texas) and after the Artisan procedure with 5 interrupted 10-0 nylon 
sutures. At the end of the Artiflex procedure, a $1.0 \mathrm{cc}$ subconjunctival steroid injection (Celestone ${ }^{\circledR}$, Schering-Plough, Kenilworth, New Jersey) is administered. The surgical technique for the enclavation of the lens and postoperative medication is basically the same as that used with standard Artisan PIOLs and has been described before. . $^{140-22}$

Included patients showed a stable postoperative refraction and were examined preoperatively and at day 1 , week 1 , month 1,3 and 6 , and from then at 6-month intervals.

\section{Data analysis}

For statistical analysis and comparisons between preoperative and postoperative data, a parametric paired Student's t-tests was used $(P<0.05$ being significant). We compared absolute values, since a shift to more negative aberration values does not automatically mean a reduction of the wavefront error if preoperative values are negative. To maintain an overall level of less than 0.01 for multiple tests, a Bonferroni correction was performed. (SPSS for Windows, SPSS Inc., Chicago, IL). Increase factors were used to reflect the wavefront change in relation to the preoperative value (absolute values were used).

Snellen visual acuities were transformed to LogMAR values for statistical comparison.

Wavefront analysis was performed for pupil diameters of $6.0 \mathrm{~mm}$. Results from the wavefront examinations were transformed into absolute values for statistical analysis. Zernike coefficients up to the $4^{\text {th }}$ order are currently included in the measurements. Calculations were performed using HOA, trefoil-x, trefoil-y, coma-x, coma-y and spherical aberration.

Correlations between clinical parameters such as visual acuity and refractive outcome were performed for data obtained at the 12 month follow-up examination and assessed with the Pearson $r$ coefficient of correlation. Intergroup comparisons were made using an independent samples Student's t-test. All values in the text are mean \pm standard deviation (SD).

\section{RESULTS}

\section{Patient population}

In the Artiflex group, 8 patients were female and 6 were male (Table 1). The mean preoperative patient age was $41 \pm 8$ years (26 to 51 years). The mean anterior chamber depth was $3.66 \pm 0.33 \mathrm{~mm}$ (range, 3.20 to $4.72 \mathrm{~mm}$ ) and the mean intraocular pressure was $14.77 \pm 2.63 \mathrm{mmHg}$ (range, 10.0 to $19.0 \mathrm{mmHg}$ ). The mean power of the implanted PIOL was $-9.57 \pm 4.23 \mathrm{D}$ (range, -8.0 to $-12.50 \mathrm{D})$. 
Table 1. Summary of population characteristics and preoperative data for the Artiflex and Artisan Phakic Intraocular Lens groups for the correction of myopia.

\begin{tabular}{lccccc}
\hline & \multicolumn{2}{c}{ Artiflex group } & & \multicolumn{2}{c}{ Artisan group } \\
\cline { 2 - 3 } \cline { 5 - 6 } Variable & Mean $\pm \mathrm{SD}$ & Range & & Mean $\pm \mathrm{SD}$ & Range \\
\hline Mean patient age (yrs) & $41.0 \pm 7.8$ & 26 to 51 & & $40.0 \pm 12.0$ & 18 to 52 \\
Number of eyes & 27 & & & 22 & \\
Number of females & 8 & & & 9 & \\
ACD $(\mathrm{mm})$ & $3.66 \pm 0.33$ & 3.20 to 4.72 & & $3.71 \pm 0.29$ & 3.0 to 4.0 \\
IOP $(\mathrm{mmHg})$ & $14.77 \pm 2.63$ & 10.0 to 19.0 & & $14.19 \pm 3.04$ & 10.0 to 20.0 \\
Implanted lens power (D) & $-9.57 \pm 1.11$ & -8.0 to -12.50 & $-10.82 \pm 2.69$ & -5.0 to -15.0 \\
Mesopic-low pupil size (mm) & $4.95 \pm 1.11$ & 3.34 to 6.69 & & $3.84 \pm 0.79$ & 2.64 to 5.32 \\
\hline SD = standard deviation; ACD $=$ anterior & chamber depth; IOP $=$ intraocular pressure; \\
D = diopters.
\end{tabular}

Table 2. Summary of the visual and refractive data for the Artiflex and Artisan Phakic Intraocular Lens groups.

\begin{tabular}{|c|c|c|c|c|}
\hline \multirow[b]{2}{*}{ Variable } & \multicolumn{2}{|c|}{ Artiflex group $(n=27)$} & \multicolumn{2}{|c|}{ Artisan group $(n=22)$} \\
\hline & Pre-op & Post-op & Pre-op & Post-op \\
\hline Sphere $(\mathrm{D})^{\star}$ & $-9.57 \pm 1.43$ & $0.02 \pm 0.46$ & $-9.33 \pm 2.72$ & $0.02 \pm 0.45$ \\
\hline Cylinder $(\mathrm{D})^{\star}$ & $-0.77 \pm 0.53$ & $-0.51 \pm 0.52$ & $-1.14 \pm 0.65$ & $-0.48 \pm 0.53$ \\
\hline $\mathrm{SE}(\mathrm{D})^{\star}$ & $-9.95 \pm 1.43$ & $-0.23 \pm 0.40$ & $-9.90 \pm 2.74$ & $-0.21 \pm 0.45$ \\
\hline LogMAR BCVA^ & $0.0 \pm 0.07$ & $-0.11 \pm 0.07$ & $0.05 \pm 0.10$ & $-0.01 \pm 0.08$ \\
\hline Snellen BCVA of $\geq 20 / 20$ & & $100 \%$ & & $77.0 \%$ \\
\hline Loss of $\geq 1$ Snellen BCVA lines & & $0 \%$ & & $4.8 \%$ \\
\hline
\end{tabular}

$\star$ Values are mean \pm standard deviation. $\mathrm{D}=$ diopters; $\mathrm{SE}=$ spherical equivalent; $\mathrm{BCVA}=$ best-corrected visual acuity; PIOL $=$ phakic intraocular lens.

In the Artisan group, 9 patients were female and 4 were male. The mean preoperative patient age was $40 \pm 12$ years (18 to 52 years). The mean anterior chamber depth was $3.71 \pm 0.29 \mathrm{~mm}$ (range, 3.0 to $4.0 \mathrm{~mm}$ ) and the mean intraocular pressure was $14.19 \pm 3.04 \mathrm{mmHg}$ (range, 10.0 to $20.0 \mathrm{mmHg}$ ). The mean power of the implanted PIOL was $-10.82 \pm 2.69 \mathrm{D}$ (range, -5.0 to $-15.0 \mathrm{D}$ ).

\section{Clinical outcome}

For the Artiflex group, the mean preoperative spherical equivalent (SE) changed from $-9.95 \pm 1.43 \mathrm{D}$ (range, -6.75 to $-12.13 \mathrm{D}$ ) to $-0.23 \pm 0.40 \mathrm{D}$ (range, -1.25 to $0.75 \mathrm{D}$ ), postoperatively (Table 2 ). After 1 year, $85.7 \%$ of eyes were within \pm $0.5 \mathrm{D}$ of the desired refraction. The mean refractive cylinder changed from -0.77 \pm 0.53 preoperatively to $-0.57 \pm 0.54 \mathrm{D}$ at 1 week, $-0.49 \pm 0.49 \mathrm{D}$ at 1 month, $-0.54 \pm 0.47 \mathrm{D}$ at 3 months and $-0.51 \pm 0.52 \mathrm{D}$ at 1 year follow-up. The mean preoperative $\log$ MAR BCVA changed from $0.0 \pm 0.07$ (range, -0.08 to 0.15 ) to 
$-0.09 \pm 0.07$ (range, -0.18 to 0.0$)(P=0.001)$. A Snellen BCVA of $\geq 20 / 20$ was found in $100 \%$ of eyes and no eyes lost any Snellen lines of BCVA.

For the Artisan group, the mean preoperative SE changed from $-9.90 \pm 2.74$ $\mathrm{D}(-4.0$ to $-14.50 \mathrm{D})$ to $-0.21 \pm 0.45 \mathrm{D}(-1.0$ to $0.75 \mathrm{D})$, postoperatively. After 1 year, $76.2 \%$ of eyes were within $\pm 0.5 \mathrm{D}$ of the desired refraction. The mean refractive cylinder changed from $-1.14 \pm 0.65$ preoperatively to $-2.35 \pm 1.39 \mathrm{D}$ at 1 week, $-0,79 \pm 0.76 \mathrm{D}$ at 1 month, $-0.63 \pm 0.58 \mathrm{D}$ at 3 months and $-0.48 \pm$ $0.53 \mathrm{D}$ at 1 year follow-up. A comparison between the 2 lens groups showed that there was a significant difference between the refractive cylinder value at 1 week follow-up $(P=0.001)$, and from month 1 there was no significant difference between the groups.

The mean preoperative logMAR BCVA changed from $0.05 \pm 0.10$ (range, -0.10 to 0.22$)$ to $-0.01 \pm 0.08$ (range, -0.10 to 0.10$)(P=0.003)$, postoperatively. A Snellen BCVA of $\geq 20 / 20$ was found in $77.0 \%(n=17)$ of eyes and $4.8 \%(n=1)$ lost 1 or more Snellen lines of BCVA.

In the Artiflex and Artisan groups, the mean postoperative IOP were $16.76 \pm$ $3.36 \mathrm{mmHg}$ (range, 10 to $24 \mathrm{mmHg}$ ) and $15.5 \pm 2.71 \mathrm{mmHg}$ (range, 10 to 19 $\mathrm{mmHg})$, respectively $(P=0.23)$.

\section{Clinical HOA changes}

For both the Artiflex and Artisan groups, the mean numerical changes and comparisons before and after surgery are displayed in Table 3 and Figs. 2 to 7.

In the Artiflex group, there was a statistically significant difference in trefoil-y (increase factor 1.73) and spherical aberration (increase factor 0.55).

In the Artisan group, there was a statistically significant difference in HOA (increase factor 1.68), trefoil-y (increase factor 3.32) and spherical aberration (increase factor 6.84).

The difference between the increase factors for SA were statistically significant $(P=0.04)$.

\section{Laboratory $H O A$ evaluation}

Laboratory analysis of the 2 PIOLs showed the Artiflex PIOL to have negative primary spherical aberration and the Artisan PIOL to have positive primary spherical aberration. Spherical aberration corresponds with Zernike mode number 12. An analysis overview of the spherical aberration profiles for the Artiflex and Artisan groups is displayed in Fig. 8.

Spherical aberration changed negligibly with 100 and 200 micron decentrations with a 4 and $5 \mathrm{~mm}$ pupil diameter. 


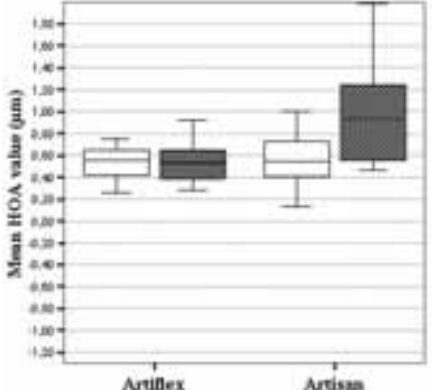

Figure 2. Changes in total higher order aberrations (HOA) before and after Artiflex versus Artisan Phakic Intraocular Lens implantation for the correction of myopia.

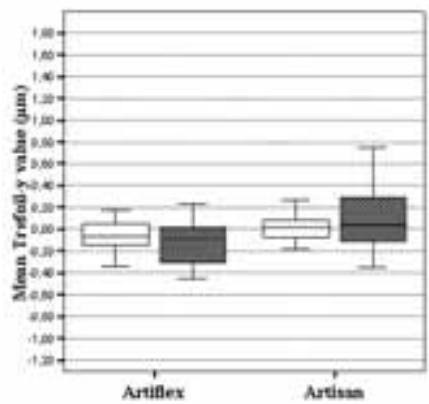

Figure 4. Changes in trefoil-y before and after Artiflex versus Artisan Phakic Intraocular Lens implantation for the correction of myopia.
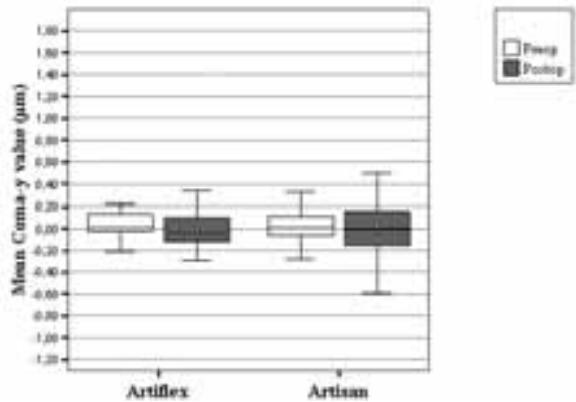

Figure 6. Changes in coma-y before and after Artiflex versus Artisan Phakic Intraocular Lens implantation for the correction of myopia.

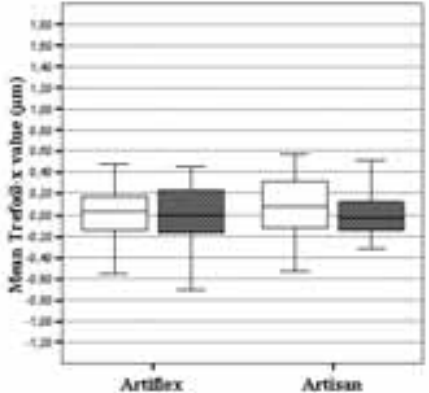

Figure 3. Changes in trefoil-x before and after Artiflex versus Artisan Phakic Intraocular Lens implantation for the correction of myopia.

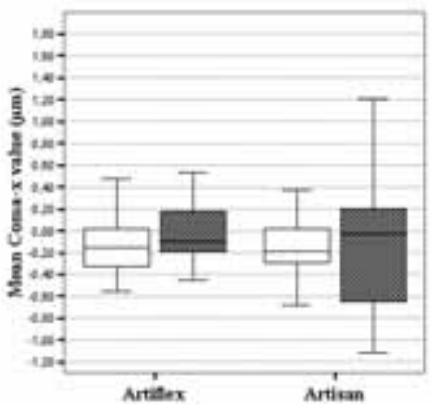

Figure 5. Changes in coma-x before and after Artiflex versus Artisan Phakic Intraocular Lens implantation for the correction of myopia.
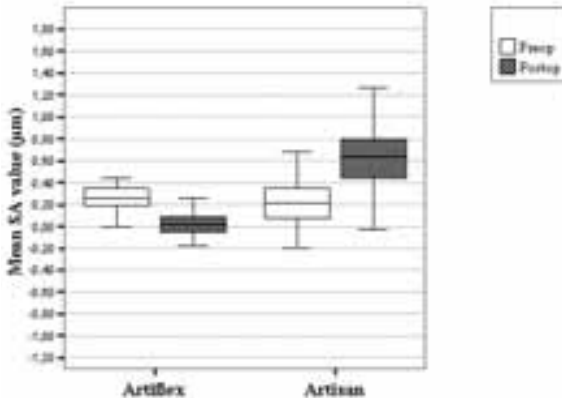

Figure 7. Changes in spherical aberration before and after Artiflex versus Artisan Phakic Intraocular Lens implantation for the correction of myopia. 


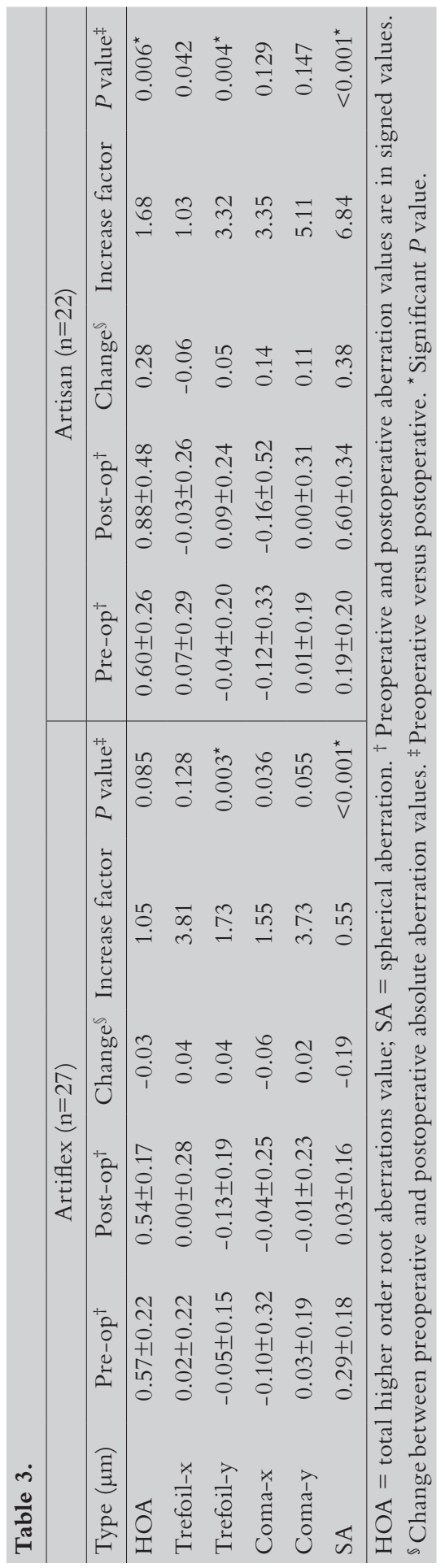




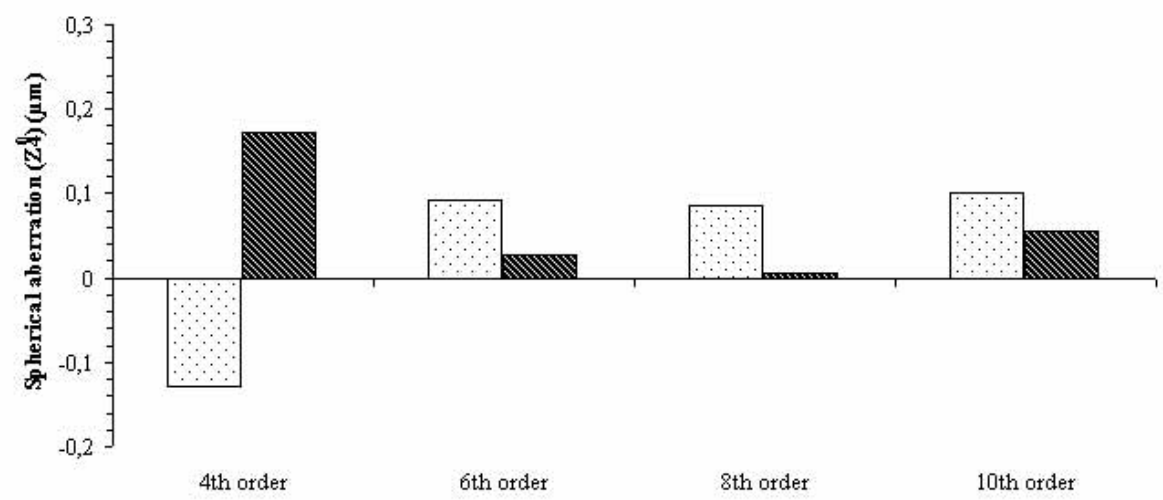

Figure 8. Artiflex and Artisan Phakic Intraocular Lens laboratory higher order aberration measurements over a $6 \mathrm{~mm}$ pupil diameter.

\section{Pupil sizes and PIOL decentration}

For the Artiflex group, the mean mesopic-low pupil size was $4.95 \pm 1.11 \mathrm{~mm}$ (range, 3.34 to $6.69 \mathrm{~mm}$ ). The mean amount of PIOL decentration was $0.24 \pm$ $0.12 \mathrm{~mm}$ (range, 0.06 to $0.54 \mathrm{~mm}$ ). A decentration of more than $0.5 \mathrm{~mm}$ was found in $3.7 \%$ of eyes $(n=1)$. There was a significant correlation between PIOL decentration and post-operative SA $(\mathrm{r}=-0.42, P=0.03)$ and coma-y $(\mathrm{r}=0.44$, $P=0.02)$.

For the Artisan group, the mean mesopic-low pupil size was $3.84 \pm 0.79 \mathrm{~mm}$ (range, 2.64 to $5.32 \mathrm{~mm}$ ). The mean amount of PIOL decentration was $0.25 \pm$ $0.12 \mathrm{~mm}$ (range, 0.10 to $0.46 \mathrm{~mm}$ ). A decentration of more than $0.5 \mathrm{~mm}$ was found in none of the eyes. No significant correlations with postoperative aberrations were found.

\section{DISCUSSION}

The aim of this study was to evaluate changes in total and individual HOA after Artiflex PIOL implantation for the correction of myopia and make a comparison to a matched patient group after Artisan PIOL implantation.

By now it has been well established that the recently FDA approved PMMA Artisan PIOL is a safe, effective and predictable device for the surgical correction of moderate to high myopia..$^{4,22,24,29,34-36}$ The foldable Artiflex iris-fixated PIOL, on the other hand, is a relatively new development in the area of lenticular refrac- 
tive surgery for the correction of myopia ${ }^{25,28,29}$ and is currently being evaluated in a European multicenter study.

The Artiflex lens design is based on the Artisan lens design, with haptics comparable to the Artisan myopia lens. In the Artiflex lens the haptics are also made of PMMA, while the foldable optical zone is made of silicone and has the advantage of an insertion of the PIOL through a smaller $3.4-\mathrm{mm}$ incision. The Artiflex lens theoretically represents an improvement of the iris-supported PIOL concept leading to a lower level of induced surgical astigmatism.

Recently, a randomized, paired-eye study compared the Artiflex and the Artisan lenses and found that one year after surgery, the percent of eyes with UCVA > 20/40 was statistically better for Artiflex with a higher efficacy index and a faster and better visual recovery time for Artiflex-treated eyes during the early postoperative period. ${ }^{29}$ Another report on the Artiflex lens reported that 6-months after surgery, there was no loss of Snellen BCVA, with $91 \%$ of eyes within \pm 0.5 D of the targeted refraction and $82 \%$ of eyes reaching a Snellen UCVA of 20/25 or better. ${ }^{28}$

The evaluation of changes in HOA in the field of refractive surgery is not a new occurrence. Several studies have shown that laser refractive surgery techniques such as PRK and LASIK can lead to a significant increase in postoperative total and individual HOA.4-6, 37-40 There are also several reports that have studied changes in HOA after PIOL implantations, mostly after Artisan PIOL implantation in myopic eyes. ${ }^{3,41}$ Among these, there was a study that demonstrated higher postoperative trefoil, which the authors attributed to the incision size and also higher postoperative spherical aberration, according to them lens-related. A recent study that changes in HOA after Artiflex lens implantation found no significant tendency toward increasing HOA (e.g. coma and spherical aberration) which they attributed to preservation of the corneal asphericity. ${ }^{42}$

Evaluation of the changes in aberration profiles in both lens groups showed that postoperative spherical aberration decreased significantly in the Artiflex group and increased significantly in the Artisan group. This reduction in postoperative spherical aberration in the Artiflex group may be attributed to the negative spherical aberration noted in bench testing which was performed on the Artiflex lens. This finding of negative spherical aberration may help compensate for the positive spherical aberration present in the normal preoperative population. ${ }^{43}$ Thus, the total amount of positive spherical aberration may be reduced after Artiflex PIOL surgery. In contrast, we measured a modest amount of positive spherical aberration in the Artisan group, which may have added to the positive spherical aberration which is present in the normal preoperative eye, which increased the amount of positive spherical aberration postoperatively in the Artisan group. In addition, differences in spherical aberration profiles between both lens groups may be induced by differences in incision size and wound healing. Differences in the spherical aberration profile between the Artiflex and the Artisan lens with a 6-mm analysis pupil diameter may be due to differences in lens rim design 
(see also Fig. 1). Currently, the exact cause and relation to lens design factors is unknown and needs further investigation. Another finding was that in both lens groups, trefoil-y increased significantly. These changes might be the result of the smaller incision size in the Artiflex group. Some previous studies that analyzed HOA changes in cataract surgery have also suggested that trefoil changes may be related to the surgical procedure, e.g. the incision size and position. ${ }^{44}$ Further studies seem warranted to observe our observations, since they cannot be fully explained by the present small study.

The refractive results at 1 year were similar for the Artiflex and Artisan groups. Both lenses lead to a postoperative SE close to zero and about $80 \%$ of eyes within $\pm 0.5 \mathrm{D}$ of the desired refraction. Refractive astigmatism was significantly different only at 1 week follow-up, demonstrating that thereafter the amount of refractive astigmatism was comparable for the 2 lens groups, despite differences in incision size. The finding of comparable astigmatism values in Artiflex and Artisan eyes has been recently demonstrated by Coullet who also did not find a significant difference in postoperative astigmatism beyond 3 months follow-up. ${ }^{29}$ The resulting decrease in corneal astigmatism for the Artisan group was attributed to the suture removal after this time point.

In conclusion, our study demonstrated a decrease in spherical aberration after implantation of a foldable Artiflex PIOL in myopic eyes, which may be related to the lens compensating for the positive spherical aberration preoperatively, and showed an increase in postoperative spherical aberration after rigid Artisan PIOL implantation. The aberration differences may also be related to other factors such as incision size and deserve further investigation. 


\section{REFERENCES}

1. Kohnen T, Bühren J, Cichocki M, et al. [Optical quality after refractive corneal surgery]. Ophthalmologe 2006;103(3):184-191.

2. Sarver EJ, Sanders DR, Vukich JA. Image quality in myopic eyes corrected with laser in situ keratomileusis and phakic intraocular lens. J Refract Surg 2003;19(4):397-404.

3. Brunette I, Bueno JM, Harissi-Dagher M, et al. Optical quality of the eye with the Artisan phakic lens for the correction of high myopia. Optom Vis Sci 2003;80(2):167-174.

4. Oshika T, Miyata K, Tokunaga T, et al. Higher order wavefront aberrations of cornea and magnitude of refractive correction in laser in situ keratomileusis. Ophthalmology 2002;109(6):1154-1158.

5. Yamane N, Miyata K, Samejima T, et al. Ocular higher-order aberrations and contrast sensitivity after conventional laser in situ keratomileusis. Invest Ophthalmol Vis Sci 2004;45(11):3986-3990.

6. Kohnen T, Mahmoud K, Bühren J. Comparison of corneal higher-order aberrations induced by myopic and hyperopic LASIK. Ophthalmology 2005;112(10):1692.

7. Qazi MA, Roberts CJ, Mahmoud AM, Pepose JS. Topographic and biomechanical differences between hyperopic and myopic laser in situ keratomileusis. J Cataract Refract Surg 2005;31(1):48-60.

8. Kohnen T, Bühren J, Kühne C, Mirshahi A. Wavefront-guided LASIK with the Zyoptix 3.1 system for the correction of myopia and compound myopic astigmatism with 1-year follow-up: clinical outcome and change in higher order aberrations. Ophthalmology 2004;111(12):2175-2185.

9. Alió JL, Montés-Micó R. Wavefront-guided versus standard LASIK enhancement for residual refractive errors. Ophthalmology 2006;113(2):191-197.

10. Alió J, Galal A, Montalban R, Pinero D. Corneal wavefront-guided LASIK retreatments for correction of highly aberrated corneas following refractive surgery. J Refract Surg 2007;23(8):760-773.

11. Bühren J, Strenger A, Martin T, Kohnen T. [Wavefront aberrations and subjective quality of vision after wavefront-guided LASIK: first results]. Ophthalmologe 2007;104(8):688-692, 694-686.

12. Gemoules G, Morris KM. Rigid gas-permeable contact lenses and severe higher-order aberrations in postsurgical corneas. Eye Contact Lens 2007;33(6 Pt 1):304-307.

13. Villa C, Gutierrez R, Jimenez JR, Gonzalez-Meijome JM. Night vision disturbances after successful LASIK surgery. Br J Ophthalmol 2007;91(8):1031-1037.

14. Tahzib NG, Bootsma SJ, Eggink FA, Nuijts RM. Functional outcome and patient satisfaction after Artisan phakic intraocular lens implantation for the correction of myopia. Am J Ophthalmol 2006;142(1):31-39.

15. Benedetti S, Casamenti V, Marcaccio L, et al. Correction of myopia of 7 to 24 diopters with the Artisan phakic intraocular lens: two-year follow-up. J Refract Surg 2005;21(2):116-126.

16. Lifshitz T, Levy J, Aizenman I, et al. Artisan phakic intraocular lens for correcting high myopia. Int Ophthalmol 2004;25(4):233-238. 
17. Pop M, Payette Y. Initial results of endothelial cell counts after Artisan lens for phakic eyes: an evaluation of the United States Food and Drug Administration Ophtec Study. Ophthalmology 2004;111(2):309-317.

18. Menezo JL, Peris-Martinez C, Cisneros AL, Martinez-Costa R. Phakic intraocular lenses to correct high myopia: Adatomed, Staar, and Artisan. J Cataract Refract Surg 2004;30(1):33-44.

19. Maloney RK, Nguyen LH, John ME. Artisan phakic intraocular lens for myopia:short-term results of a prospective, multicenter study. Ophthalmology 2002;109(9):1631-1641.

20. Malecaze FJ, Hulin H, Bierer P, et al. A randomized paired eye comparison of two techniques for treating moderately high myopia: LASIK and artisan phakic lens. Ophthalmology 2002;109(9):1622-1630.

21. El Danasoury MA, El Maghraby A, Gamali TO. Comparison of iris-fixed Artisan lens implantation with excimer laser in situ keratomileusis in correcting myopia between -9.00 and -19.50 diopters: a randomized study. Ophthalmology 2002;109(5):955-964.

22. Budo C, Hessloehl JC, Izak M, et al. Multicenter study of the Artisan phakic intraocular lens. J Cataract Refract Surg 2000;26(8):1163-1171.

23. Landesz M, Worst JG, van Rij G. Long-term results of correction of high myopia with an iris claw phakic intraocular lens. J Refract Surg 2000;16(3):310-316.

24. Moshirfar M, Holz HA, Davis DK. Two-year follow-up of the Artisan/Verisyse irissupported phakic intraocular lens for the correction of high myopia. J Cataract Refract Surg 2007;33(8):1392-1397.

25. Kohnen T, Cichocki M, Koss MJ. Position of rigid and foldable iris-fixated myopic phakic intraocular lenses evaluated by Scheimpflug photography. J Cataract Refract Surg 2008;34(1):114-120.

26. Koss MJ, Cichocki M, Kohnen T. Posterior synechias following implantation of a foldable silicone iris-fixated phakic intraocular lens for the correction of myopia. J Cataract Refract Surg 2007;33(5):905-909.

27. Tahzib NG, Eggink FA, Frederik PM, Nuijts RM. Recurrent intraocular inflammation after implantation of the Artiflex phakic intraocular lens for the correction of high myopia. J Cataract Refract Surg 2006;32(8):1388-1391.

28. Tehrani M, Dick HB. Short-term follow-up after implantation of a foldable iris-fixated intraocular lens in phakic eyes. Ophthalmology 2005;112(12):2189-2195.

29. Coullet J, Güell JL, Fournie P, et al. Iris-supported phakic lenses (rigid vs foldable version) for treating moderately high myopia: randomized paired eye comparison. Am J Ophthalmol 2006;142(6):909-916.

30. Kohnen T, Terzi E, Kasper T, et al. Correlation of infrared pupillometers and CCDcamera imaging from aberrometry and videokeratography for determining scotopic pupil size. J Cataract Refract Surg 2004;30(10):2116-2123.

31. Mirshahi A, Bühren J, Gerhardt D, Kohnen T. In vivo and in vitro repeatability of Hartmann-Shack aberrometry. J Cataract Refract Surg 2003;29(12):2295-2301.

32. Porter J, MacRae S, Yoon G, et al. Separate effects of the microkeratome incision and laser ablation on the eye's wave aberration. Am J Ophthalmol 2003;136(2):327-337. 
33. Hament WJ, Nabar VA, Nuijts RM. Repeatability and validity of Zywave aberrometer measurements. J Cataract Refract Surg 2002;28(12):2135-2141.

34. Tahzib NG, Nuijts RM, Wu WY, Budo CJ. Long-term study of Artisan phakic intraocular lens implantation for the correction of moderate to high myopia: ten-year follow-up results. Ophthalmology 2007;114(6):1133-1142.

35. Güell JL, Morral M, Gris O, et al. Five-Year Follow-up of 399 Phakic Artisan-Verisyse Implantation for Myopia, Hyperopia, and/or Astigmatism. Ophthalmology 2007.

36. Stulting RD, John ME, Maloney RK, et al. Three-Year Results of Artisan/Verisyse Phakic Intraocular Lens Implantation Results of the United States Food and Drug Administration Clinical Trial. Ophthalmology 2007.

37. Applegate RA, Hilmantel G, Howland HC. Corneal aberrations increase with the magnitude of radial keratotomy refractive correction. Optom Vis Sci 1996;73(9):585-589.

38. Marcos S, Barbero S, Llorente L, Merayo-Lloves J. Optical response to LASIK surgery for myopia from total and corneal aberration measurements. Invest Ophthalmol Vis Sci 2001;42(13):3349-3356.

39. Mierdel P, Kaemmerer M, Krinke HE, Seiler T. Effects of photorefractive keratectomy and cataract surgery on ocular optical errors of higher order. Graefes Arch Clin Exp Ophthalmol 1999;237(9):725-729.

40. Hjortdal JO, Olsen H, Ehlers N. Prospective randomized study of corneal aberrations 1 year after radial keratotomy or photorefractive keratectomy. J Refract Surg 2002;18(1):23-29.

41. Bühren J, Kasper T, Terzi E, Kohnen T. [Higher order aberrations after implantation of an iris claw pIOL (Ophtec Artisan) in the phakic eye]. Ophthalmologe 2004;101(12):1194-1201.

42. Tehrani M, Dick HB. Changes in higher-order aberrations after implantation of a foldable iris-claw lens in myopic phakic eyes. J Cataract Refract Surg 2006;32(2):250-254.

43. Guirao A, Porter J, Williams DR, Cox IG. Calculated impact of higher-order monochromatic aberrations on retinal image quality in a population of human eyes. J Opt Soc Am A Opt Image Sci Vis 2002;19(1):1-9.

44. Guirao A, Tejedor J, Artal P. Corneal aberrations before and after small-incision cataract surgery. Invest Ophthalmol Vis Sci 2004;45(12):4312-4319. 
198

Chapter 10 
General Discussion 
Visual problems can often arise in persons with moderate to high refractive errors and lead to contact lens and/or spectacle intolerance, creating severe problems in the daily activities. For persons seeking contact lens or spectacle independence, corneal and/or refractive surgery can offer promising alternatives. In this thesis, the subjective and clinical outcome of several refractive surgery techniques are evaluated in virgin eyes and eyes that have previously undergone keratoplasty.

During the evaluation and selection process of potential refractive surgery candidates, it is standard practice to measure the patients' pupil size. The pupil size is an important parameter to take into account since it has been long-time postulated that pupil size could be an important predictor of night vision complaints after refractive surgery procedures such as laser in situ keratomileusis (LASIK) and phakic intraocular lens (pIOL) implantations. However, this issue is still in debate since a few recent studies found no direct correlations between large pupil sizes and night vision disturbances or visual funcation. ${ }^{1-3}$

In our study on patient satisfaction after LASIK for the treatment of myopia we found no significant correlation between the scotopic pupil size or the pupiloptical zone disparity and patient satisfaction (specifically glare and night vision), leading to our belief that eyes with larger pupils can be considered for laser refractive surgery, considering that patients are thoroughly informed on the possibility of short-term postoperative glare and halo's.

As for preoperative pupil size and pIOL implantations, our studies show that the horizontal pupil diameter decreases after Artisan pIOL implantation with an increase in the vertical/horizontal ratio. In addition, we showed that the scotopic, but not the mesopic-low, pupil-optical zone disparity is related to night vision complaints in patients. This is important, since mesopic-low conditions are a better representation of "real-life" situations. Therefore, we believe that eyes with larger pupil sizes can be still considered for treatment with pIOLs.

Pupil size measurements should reflect real-time situations as much as possible and we believe that objective digital binocular infrared pupillometry in mesopiclow conditions is most appropriate for standardized measurements, since it is more reproducible and approximates "real life" conditions more closely than the subjective measurements with a monocular pupillometer. The role of pupil size in the process of selecting suitable refractive surgery candidates will continue to need further scientific investigation. The objective quantification of pupil size will assist in the evaluation of the exact relationship between night vision complaints and pupil size under various light conditions.

The assessment and improvement of patient satisfaction will continue to play an important role in the field of refractive surgery. With the increasing variety of available refractive surgery techniques and the many choices which the refractive surgery candidate faces, it is increasingly important that the patient is thoroughly analyzed and advised before the procedure he or she is seeking. 
The importance of evaluating patient satisfaction in the patient group is re-emphasized by the recent announcement of the American Society of Cataract and Refractive Surgery (ASCRS) that it will participate in a post-LASIK quality of life study with the Joint LASIK Study Task Force, which includes the U.S. Food and Drug Administration, the National Eye Institute, ASCRS and the American Academy of Ophthalmology. In addition, results of a very recent meta-analysis review by Kerry Solomon, MD (which was presented at the annual Symposium and Congress of the ASCRS, April 4-9 in 2008, in Chicago), showed that $95.4 \%$ of LASIK patients worldwide report satisfaction with the outcome of their procedure with a total range of satisfaction rates in individual studies from $87.2 \%$ to $100 \%$. This review examined nearly 3,000 peer-reviewed articles published over the past 10 years in clinical journals from North America, South America, Europe, Asia, Africa and Australia.

We recommend that patients be thoroughly counseled on the potential side effects of the planned procedure and offer alternative surgical techniques. It is also important to determine the patients' motivations and expectations before surgery, since the relationship between patient expectations, the medical outcome, and patient satisfaction is complex and the clinical outcome does not always directly correlate with the subjective outcome. When studying patient satisfaction, we recommend to use standardized methods, such as validated patient questionnaires, and offer them to patients before and after the surgical procedure. We believe that self-administered tests, rather than physician-administered tests, enable a more objective view of patient satisfaction and quality of vision.

As to the outcomes of the various corneal and refractive surgery techniques which we discussed in this thesis, it seems that patient satisfaction after both LASIK and Artisan pIOL implantation is comparable. We propose that this comparable finding is related to the precise selection of suitable candidates before the individual procedure. This means that when refractive surgery candidates are carefully examined, counseled and selected, patient satisfaction is generally high after most refractive surgery techniques.

For the past decade, LASIK has been the preferred refractive surgical procedure for patients seeking contact lens or spectacle independence. Although it is generally known that the medical outcome of LASIK is excellent ${ }^{4-8}$, in order to draw more complete and final conclusions on this refractive surgery procedure, further studies are needed with larger amounts of patients, longer follow-up, and evaluation of the modern generation equipment and instruments. As for wavefront and aspheric laser treatments, it is still not very clear whether the excellent results with these procedures are related to better postoperative asphericity profiles or due to treatment of preexistent higher order aberrations (HOA). Only a few randomized controlled trials have compared wavefront/aspheric to conventional treatments and show that customized aspheric treatments might induce less aber- 
rations, namely spherical aberration and better maintain the physiology of the corneal surface. ${ }^{9,10}$

Although the medical outcome of LASIK for the correction of moderate degrees of ametropia has been shown to be excellent, it is generally agreed that LASIK be not performed in patients with high degrees of ametropia or astigmatism. For these eyes with higher degrees of myopia, laser ablative procedures such as LASIK are a less desirable procedure, which is related to the higher risk of reduced postoperative quality of vision and a trend toward myopic regression. ${ }^{8,11}$, ${ }^{12}$ Another rare, but dramatic complication that can occur after LASIK is corneal ectasia, that develops due to biomechanical corneal changes after the procedure. Post-LASIK ectasia has been shown to occur with an incidence between $0.12 \%$ and $0.66 \%$. The risk of post-LASIK ectasia seems to be higher in eyes with preoperative irregular topography, thin corneas, thin remaining corneal beds, forme fruste keratoconus, thick corneal flaps, large optical zones, and high myopia. ${ }^{13-19}$ The implantation of an iris-fixated pIOL in virgin and highly aberrated eyes (e.g. after keratoplasty) represents a promising development for vision correction in patients with high degrees of ametropia or astigmatism and has been studied for several years now. ${ }^{20-24}$ The meticulous selection of suitable pIOL patients will become increasingly important, and we expect the inclusion criteria to be expanded, with the advent of newer imaging systems that can accurately determine the sizing issues involved with the placement of pIOLs in the anterior chamber. Further research should be aimed at consistently evaluating larger number of patients who have undergone pIOL implantation. For the evaluation of the outcome of pIOL implantation, we suggest that surgeons continue to pay special attention to the clinical follow-up of these patients. Particularly, regular and adequate endothelial cell density measurements on a yearly basis should be performed and the implementation of the newer anterior imaging devices is necessary to detect a change in the morphometric relationship between pIOL and endothelium in the anterior chamber. The recall in 2007 ordered by the French government of 3 models of angle-supported, anterior chamber pIOLs due to excessive endothelial cell loss in the immediate postoperative years, once again point out the importance of remaining cautious and meticulous in our clinical judgement and postoperative evaluation of eyes treated with pIOL implantations.

Next to the correction of the degree of ametropia by the implantation of pIOLs, leading to the independence of spectacles or contact lens, the prevention and/ or correction of HOAs in this patient group will continue to play an important role. This is especially important in patients with higher degrees of refractive error, since refractive surgical techniques in these patients can lead to excessive HOAs and reduce quality of vision. ${ }^{25-27} \mathrm{~A}$ few studies have analyzed aberration changes after pIOL implantations. Among others, they suggested that higher 
postoperative trefoil was related to the incision size and higher postoperative spherical aberration to the lens itself. ${ }^{27,}{ }^{28}$ Questions that remain are: what is the exact cause and mechanism for aberration changes in pIOL implantations, and how do they relate to patient satisfaction? And finally, what is the exact role of the implanted lens type, e.g. rigid Artisan pIOL and foldable Artiflex pIOL? A recent study that compared both lens types showed that the Artiflex lens provided faster visual recovery and a better UCVA than the Artisan lens, but this study did not evaluate wavefront changes. ${ }^{22}$ It is currently unclear how HOAs and a change in their profile after pIOL implantation relate to better medical outcome and/ or improved patient satisfaction. The next years will undoubtedly demonstrate clinical studies that discuss ways to more effectively prevent and correct excessive HOAs. 


\section{REFERENCES}

1. Klyce SD. Night vision after LASIK: the pupil proclaims innocence. Ophthalmology 2004;111:1-2.

2. Pop M, Payette Y. Risk factors for night vision complaints after LASIK for myopia. Ophthalmology 2004;111:3-10.

3. Schmidt GW, Yoon M, McGwin G, Lee PP, McLeod SD. Evaluation of the relationship between ablation diameter, pupil size, and visual function with visionspecific quality-of-life measures after laser in situ keratomileusis. Arch Ophthalmol 2007;125:1037-42.

4. Bailey MD, Zadnik K. Outcomes of LASIK for myopia with FDA-approved lasers. Cornea 2007;26:246-54.

5. Shortt AJ, Bunce C, Allan BD. Evidence for superior efficacy and safety of LASIK over photorefractive keratectomy for correction of myopia. Ophthalmology 2006;113:1897-908.

6. Nuijts RM, Nabar VA, Hament WJ, Eggink FA. Wavefront-guided versus standard laser in situ keratomileusis to correct low to moderate myopia. J Cataract Refract Surg 2002;28:1907-13.

7. Sugar A, Rapuano CJ, Culbertson WW, et al. Laser in situ keratomileusis for myopia and astigmatism: safety and efficacy: a report by the American Academy of Ophthalmology. Ophthalmology 2002;109:175-87.

8. Sekundo W, Bonicke K, Mattausch P, Wiegand W. Six-year follow-up of laser in situ keratomileusis for moderate and extreme myopia using a first-generation excimer laser and microkeratome. J Cataract Refract Surg 2003;29:1152-8.

9. Mastropasqua L, Toto L, Zuppardi E, et al. Photorefractive keratectomy with aspheric profile of ablation versus conventional photorefractive keratectomy for myopia correction: six-month controlled clinical trial. J Cataract Refract Surg 2006;32:109-16.

10. Zhou C, Chai X, Yuan L, He Y, Jin M, Ren Q. Corneal higher-order aberrations after customized aspheric ablation and conventional ablation for myopic correction. Curr Eye Res 2007;32:431-8.

11. Kymionis GD, Tsiklis NS, Astyrakakis N, Pallikaris AI, Panagopoulou SI, Pallikaris IG. Eleven-year follow-up of laser in situ keratomileusis. J Cataract Refract Surg 2007;33:191-6.

12. O’Doherty M, O'Keeffe M, Kelleher C. Five year follow up of laser in situ keratomileusis for all levels of myopia. Br J Ophthalmol 2006;90:20-3.

13. Dupps WJ, Jr., Wilson SE. Biomechanics and wound healing in the cornea. Exp Eye Res 2006;83:709-20.

14. Rabinowitz YS. Ectasia after laser in situ keratomileusis. Curr Opin Ophthalmol 2006;17:421-6.

15. Pallikaris IG, Kymionis GD, Astyrakakis NI. Corneal ectasia induced by laser in situ keratomileusis. J Cataract Refract Surg 2001;27:1796-802. 
16. Klein SR, Epstein RJ, Randleman JB, Stulting RD. Corneal ectasia after laser in situ keratomileusis in patients without apparent preoperative risk factors. Cornea 2006;25:388-403.

17. Binder PS. Ectasia after laser in situ keratomileusis. J Cataract Refract Surg 2003;29:2419-29.

18. Randleman JB. Post-laser in-situ keratomileusis ectasia: current understanding and future directions. Curr Opin Ophthalmol 2006;17:406-12.

19. Seiler T, Koufala K, Richter G. Iatrogenic keratectasia after laser in situ keratomileusis. J Refract Surg 1998;14:312-7.

20. Budo C, Hessloehl JC, Izak M, et al. Multicenter study of the Artisan phakic intraocular lens. J Cataract Refract Surg 2000;26:1163-71.

21. El Danasoury MA, El Maghraby A, Gamali TO. Comparison of iris-fixed Artisan lens implantation with excimer laser in situ keratomileusis in correcting myopia between -9.00 and -19.50 diopters: a randomized study. Ophthalmology 2002;109:955-64.

22. Coullet J, Guell JL, Fournie P, et al. Iris-supported phakic lenses (rigid vs foldable version) for treating moderately high myopia: randomized paired eye comparison. Am J Ophthalmol 2006;142:909-16.

23. Gierek-Ciaciura S, Gierek-Lapinska A, Ochalik K, Mrukwa-Kominek E. Correction of high myopia with different phakic anterior chamber intraocular lenses: ICARE angle-supported lens and Verisyse iris-claw lens. Graefes Arch Clin Exp Ophthalmol 2007;245:1-7.

24. Lifshitz T, Levy J, Aizenman I, Klemperer I, Levinger S. Artisan phakic intraocular lens for correcting high myopia. Int Ophthalmol 2004;25:233-8.

25. Kohnen T, Buhren J, Cichocki M, Kasper T, Terzi E, Ohrloff C. [Optical quality after refractive corneal surgery]. Ophthalmologe 2006;103:184-91.

26. Sarver EJ, Sanders DR, Vukich JA. Image quality in myopic eyes corrected with laser in situ keratomileusis and phakic intraocular lens. J Refract Surg 2003;19:397-404.

27. Brunette I, Bueno JM, Harissi-Dagher M, Parent M, Podtetenev M, Hamam H. Optical quality of the eye with the Artisan phakic lens for the correction of high myopia. Optom Vis Sci 2003;80:167-74.

28. Buhren J, Kasper T, Terzi E, Kohnen T. [Higher order aberrations after implantation of an iris claw pIOL (Ophtec Artisan) in the phakic eye]. Ophthalmologe 2004;101:1194-201. 
$206 \mid$ Chapter 11 


\section{Summary}




\section{SUMMARY}

In this thesis we set out to describe the indications for and the outcome of several corneal and refractive surgery techniques for the correction of refractive error in virgin and post-keratoplasty eyes.

Chapter 1 is a general introduction and describes the aim and outline of the thesis. Chapters 2 and 3 relate to the importance of standardized pupil size measurements under defined light conditions with good repeatability in relation to screening eligible refractive surgery candidates. This is particularly important for patients with large pupils, who do not necessarily need to be excluded from refractive surgery procedures. Also, no real long-term relationship between preoperative pupil size and postoperative glare or halos have been found. In chapter 2 we show that Procyon measurements under mesopic-low conditions compared most favourably to Colvard measurements in a group of refractive surgery screening candidates, as well as the Artisan phakic intraocular lens (pIOL) implantation group. We also stated that digital binocular infrared pupillometry might be a better technique for standardized pupil size measurements, since it approximates "real life" conditions more closely than the monocular Colvard measurements. In chapter 3 pupil size measurements using 2 different pupillometers (the more subjective handheld Colvard device and the digital Procyon device) under defined illumination levels were compared in a population of 121 eyes selected randomly out of refractive surgery screening candidates and a population of 83 eyes who underwent Artisan pIOL implantation. The mean differences in pupil diameters for both devices were comparable. The chapter also studied pupil shape after Artisan pIOL implantation. We found that after the procedure, the mean horizontal pupil diameter decreased by $13.8 \%$. An increase in the vertical/ horizontal ratio was found under all light conditions, probably attributed to a mechanical restriction of the iris in the horizontal meridian, implicating an ovalization of pupil shape in the vertical direction. The postoperative constriction in the horizontal axis and subsequent smaller pupil diameter under mesopic-low light conditions may implicate that eyes with larger pupil sizes can be treated by Artisan pIOL implantation.

In chapter 4 we report on patient satisfaction and self-perceived quality of vision after laser in situ keratomileusis surgery in 142 patients with a mean preoperative spherical equivalent (SE) of $-4.96 \pm 2.15$ diopters (D) (range, -9.13 to $-0.50 \mathrm{D}$ ). The quality of vision was assessed using a validated questionnaire.The predictability was excellent, with $86.8 \%$ of eyes within $\pm 0.5 \mathrm{D}$ and $97.0 \%$ within \pm $1.0 \mathrm{D}$ from emmetropia. Patient satisfaction was very good, the mean score was $4.10 \pm 0.71$ on a scale of 0 to 5 (a score of 5 meaning that the patient was totally satisfied). In this patient group glare complaints occurred after surgery in $47.2 \%$, however, $92.3 \%$ of the treated patients reported that they would choose the same type of surgery again if they had to make their choice again. 
In chapters 5 and 6 the application of the Artisan pIOL for the correction of myopia is discussed. In chapter 5 the Artisan pIOL is discussed by looking at patient satisfaction and visual outcome 1 year after treatment in 120 virgin eyes with a mean preoperative SE of $-12.09 \pm 4.09 \mathrm{D}$. After surgery, the mean SE was $-0.60 \pm 0.78 \mathrm{D}$. The predictability was good, with $62.4 \%$ within $\pm 0.5 \mathrm{D}$, and $81.5 \%$ within $\pm 1.0 \mathrm{D}$ from emmetropia. Lens centration was excellent, with $86.4 \%$ of pIOLs placed within $0.5 \mathrm{~mm}$ of the center of the pupil, and $100 \%$ within $0.75 \mathrm{~mm}$ from the center. There was a loss of 1 Snellen line of bestcorrected visual acuity (BCVA) in 5.0\% of eyes and a loss of 2 Snellen lines of BCVA in $0.8 \%$ of eyes. Mean scotopic pupil size was $6.2 \pm 0.79 \mathrm{~mm}$. Patient satisfaction (assessed using the same questionnaire as mentioned above) was high with the mean score being $4.22 \pm 0.56$. Night vision complaints occurred, but did not affect overall patient satisfaction. Quality of night vision was related to the scotopic pupil size, individual higher order aberrations (such as spherical aberration (SA) and coma) and the residual refractive error. Chapter 6 discusses the results of a long-term study, demonstrating the 10-year results of myopic Artisan pIOL implantation in a group of 89 eyes with a preoperative SE of -10.36 $\pm 4.69 \mathrm{D}$ (range, -3.75 to $-25.25 \mathrm{D}$ ). It showed that the mean SE remained stable after 10 years being $-0.70 \pm 1.00 \mathrm{D}$ (range, -4.00 to $2.00 \mathrm{D}) .43 .8 \%(\mathrm{n}=39)$ of eyes were within $\pm 0.5 \mathrm{D}$ of the desired refraction and $68.8 \%(\mathrm{n}=61)$ of eyes were within $\pm 1.0 \mathrm{D}$ of the desired refraction. The efficacy index was 0.80 after 10 years, a decrease probably relating to the development of age- and high myopia related changes. The majority (93.3\%) of patients maintained a BCVA of 20/40 or better. We looked at the changes in endothelial cell density (ECD) and found no significant endothelial cell loss 10 years after surgery. We know that the physiologic rate of endothelial cell loss is $0.6 \%$ per year after age 18 . Glare complaints were few after 10 years time.

Chapters 7 and 8 discuss the application of the Artisan toric IOL in patients with aberrations in the corneal shape after corneal transplantation surgery and corneal refractive surgery. Chapter 7 discusses the 3-year results of Artisan toric IOL implantation for correction of post-keratoplasty ametropia and astigmatism in 36 eyes. These eyes could not be corrected by spectacle wear because of anisometropia. The technique was shown to be effective for reduction of refractive astigmatism and ametropia. Patient satisfaction increased greatly and all patients were suitable for spectacle correction after implantation. There was a continuing endothelial cell loss from 6 months to 3 years postoperatively. In 3 cases corneal graft failure developed. Chapter 8 describes two case reports of Artisan toric aphakic IOL implantation for the correction of severe astigmatism after myopic radial keratotomy (RK). The first patient developed a postoperative hyperopic shift and cataract, for which she underwent intracapsular cataract extraction and implantation of an Artisan aphakic IOL. Later, hyperopia and astigmatism progressed, and the Artisan aphakic IOL was exchanged for an Artisan toric aphakic IOL. The other patient had residual myopic astigmatism 
and contact lens intolerance after bilateral RK. We treated her by implanting an Artisan toric pIOL in both eyes. Both cases resulted in a satisfactory outcome. In chapter 9 a complication and the consequences for the individual patient of implantation of a foldable pIOL are described. The patients' eye suffered from recurrent intraocular inflammation after myopic Artiflex pIOL implantation. The patient developed a severe cell deposition one week after the procedure. Nine months later, many cell deposits remained visible on the posterior lens surface, leading to severe glare complaints. Despite initial medical treatment, the Artiflex lens had to eventually be exchanged for a polymethyl methacrylate (PMMA) Artisan pIOL. The lens exchange resulted in a postoperative UCVA of $20 / 20$ and a disappearance of the glare complaints. Of particular concern with pIOLs is the long-term tolerance of the lens. The long-term results of the foldable Artiflex lens have yet to be demonstrated.

Finally, chapter 10 discusses differences between 2 iris-fixated pIOL models: a non-foldable PMMA Artisan pIOL and a recently developed foldable Artiflex pIOL. The chapter analyses changes in optical aberrations for the correction of myopia, which is important in order to obtain a more complete understanding of the eye's refractive error, especially in regards to eyes with higher levels of myopia and/or astigmatism. In the Artiflex group of 27 eyes, trefoil-x increased significantly and trefoil-y and SA decreased significantly. In the Artisan group of 22 eyes, trefoil-x, trefoil-y and SA increased significantly. Laboratory analysis of both lens groups showed that the Artisan lens has positive SA and the Artiflex lens has negative SA, which supports the clinical finding that the Artiflex lens induces less SA postoperatively. This difference in SA profile might be explained by differences in optic material and/or lens design. 


\section{Samenvatting}




\section{SAMENVATTING}

Dit proefschrift had als doel het beschrijven van de indicaties voor en de uitkomsten van diverse corneale en refractiechirurgie technieken voor de correctie van refractieafwijkingen in normale en post-keratoplastiek ogen.

Hoofdstuk 1 is een algemene introductie en beschrijft het doel en de opzet van dit proefschrift. Hoofdstukken 2 en 3 beschrijven het belang van gestandaardiseerde pupilgrootte metingen onder gedefinieerde lichtomstandigheden met goede reproduceerbaarheid, in relatie tot het screenen van refractiechirurgie kandidaten. Dit is vooral van belang voor patiënten met grote pupillen, die niet zonder meer uitgesloten hoeven te worden van refractiechirurgie technieken. Ook is er nog geen echte lange termijn relatie gevonden tussen de preoperatieve pupilgrootte en postoperatieve glare of halo's. In hoofdstuk 2 tonen we dat Procyon metingen onder laag-mesopische lichtomstandigheden het beste vergelijkbaar waren met de Colvard metingen in een groep van zowel refractiechirurgie kandidaten als een Artisan phake intraoculaire lens (pIOL) implantatie groep. We stelden tevens dat digitale binoculaire infrarood pupillometrie waarschijnlijk een betere techniek is voor gestandaardiseerde pupilgrootte metingen, aangezien het de "real life" condities beter imiteert dan de monoculaire Colvard metingen. In hoofdstuk 3 worden pupilgrootte metingen vergeleken die werden verricht met behulp van 2 verschillende pupillometers (het meer subjectieve handheld Colvard apparaat en het digitale Procyon apparaat) onder gedefinieerde lichtomstandigheden in een populatie van 121 ogen, die willekeurig geselecteerd waren uit refractiechirurgie kandidaten en een populatie van 83 ogen die Artisan pIOL implantatie ondergingen. Het gemiddelde verschil in pupildiameters voor beide apparaten was vergelijkbaar. Het hoofdstuk bestudeerde ook de pupilvorm na Artisan pIOL implantatie. Er werd aangetoond dat na de ingreep, de gemiddelde horizontale pupildiameter verminderde met $13.8 \%$. Een toename in de verticale/horizontale ratio werd gevonden onder alle lichtomstandigheden, wat mogelijk te maken heeft met een mechanische restrictie van de iris in de horizontale meridiaan, welke een pupil ovalizatie in de verticale richting impliceert. De postoperatieve constrictie in de horizontale as en de daardoor kleinere pupildiameter onder laagmesopische lichtomstandigheden kan betekenen dat ogen met grotere pupillen toch een Artisan pIOL implantatie kunnen ondergaan.

In hoofdstuk 4 rapporteren we over patiënttevredenheid en subjectieve kwaliteit van zien na laser in situ keratomileusis in 142 patiënten met een gemiddeld preoperatief spherisch equivalent (SE) van -4.96 \pm 2.15 dioptrie (D) (range, -9.13 tot $-0.50 \mathrm{D})$. Het kwaliteit van zien werd geëvalueerd met behulp van een gevalideerde vragenlijst. De voorspelbaarheid was zeer goed, met $86.8 \%$ van de ogen binnen $\pm 0.5 \mathrm{D}$ en $97.0 \%$ binnen $\pm 1.0 \mathrm{D}$ van emmetropie. Patiënttevredenheid was erg goed met een gemiddelde score van $4.10 \pm 0.71$ op een schaal van 0 tot 5 (een score van 5 betekent dat de patiënt geheel tevreden was). In deze patiëntengroep traden postoperatieve glare klachten op in $47.2 \%$, echter $92.3 \%$ 
van de behandelde patiënten rapporteerden dat ze dezelfde behandelingstechniek zouden kiezen als ze hun keuze nogmaals moesten maken.

In hoofdstuk 5 en 6 wordt de toepassing van de Artisan pIOL voor de correctie van myopie besproken. In hoofdstuk 5 werd de Artisan pIOL besproken door het evalueren van patiënttevredenheid en visuele resultaten 1 jaar na de behandeling in 120 ogen met een gemiddeld preoperatief SE van $-12.09 \pm 4.09 \mathrm{D}$. Na behandeling was het gemiddelde SE $-0.60 \pm 0.78$ D. De voorspelbaarheid was goed, met $62.4 \%$ binnen $\pm 0.5 \mathrm{D}$, en $81.5 \%$ binnen $\pm 1.0 \mathrm{D}$ van emmetropie. Lens centratie was zeer goed, met $86.4 \%$ van de pIOLs geplaatst binnen $0.5 \mathrm{~mm}$ van het centrum van de pupil, en $100 \%$ binnen $0.75 \mathrm{~mm}$ van het centrum. Er trad een verlies van 1 Snellen best-corrected visual acuity (BCVA) lijn op in $5.0 \%$ van de ogen en een verlies van 2 Snellen BCVA lijnen in $0.8 \%$ van de ogen. De gemiddelde scotopische pupilgrootte was $6.2 \pm 0.79 \mathrm{~mm}$. Patiënttevredenheid (geëvalueerd met dezelfde vragenlijst als hierboven genoemd) was hoog met een gemiddelde score van $4.22 \pm 0.56$. Problemen met het zien 's nachts traden op, maar beïnvloedden de algehele patiënttevredenheid niet. Kwaliteit van zien 's nachts was gerelateerd aan de scotopische pupilgrootte, individuele hogere orde aberraties (zoals spherische aberratie (SA) en coma) en de resterende refractieafwijking. Hoofdstuk 6 bespreekt de resultaten van een lange termijn studie, die de 10 -jaar resultaten toont van myope Artisan pIOL implantatie in een groep van 89 ogen met een preoperatief SE van $-10.36 \pm 4.69 \mathrm{D}$ (range, -3.75 tot $-25.25 \mathrm{D}$ ). De studie laat zien dat het gemiddelde SE stabiel bleef met een waarde van -0.70 $\pm 1.00 \mathrm{D}$ (range, -4.00 tot $2.00 \mathrm{D})$ na 10 jaar. $43.8 \%(\mathrm{n}=39)$ van de ogen bereikte een refractie binnen $\pm 0.5 \mathrm{D}$ van de gewenste refractie en $68.8 \%(\mathrm{n}=61)$ van de ogen binnen $\pm 1.0 \mathrm{D}$ van de gewenste refractie. De efficacy index was $0.80 \mathrm{na}$ 10 jaar, een vermindering welke mogelijk te wijten is aan de ontwikkeling van leeftijdsgebonden en hoge myopie gerelateerde veranderingen. De meerderheid (93.3\%) van patiënten behield een BCVA van 0.5 of meer. We bestudeerden veranderingen in endotheelceldensiteit (ECD) en vonden geen significant endotheelcelverlies 10 jaar na de ingreep. We weten dat het fysiologisch ECD verlies $0.6 \%$ per jaar is na de leeftijd van 18 jaar. Glare klachten waren zeldzaam na 10 jaar tijd.

Hoofdstuk 7 en 8 bespreken de toepassing van de Artisan torische IOL in patienten met corneale aberraties na keratoplastiek en na corneale refractiechirurgie. Hoofdstuk 7 bespreekt de 3-jaar resultaten van Artisan torische IOL implantatie voor de correctie van post-keratoplastiek ametropie en astigmatisme in 36 ogen. Deze ogen konden niet worden gecorrigeerd met behulp van brillenglazen door de grootte van de anisometropie. De Artisan torische IOL implantatie techniek toonde effectief te zijn in de vermindering van het refractie astigmatisme en ametropie. Patiënttevredenheid nam aanzienlijk toe en alle patiënten waren geschikt voor brilaanpassing na de ingreep. Er was een continu endotheelcelverlies tussen 6 maanden tot 3 jaar na de ingreep. In 3 gevallen trad een afstoting op. Hoofdstuk 8 beschrijft 2 gevallen waarbij Artisan torische aphake IOL 
implantatie werd uitgevoerd voor de correctie van fors astigmatisme na myope radiaire keratotomie ( $\mathrm{RK}$ ). De eerste patiënt ontwikkelde een postoperatieve hypermetrope shift en cataract, waarvoor zij een intracapsulaire cataractextractie en implantatie van een Artisan afake IOL onderging. De hypermetropie en astigmatisme toonde later progressie, en werd de Artisan afake IOL uitgewisseld voor een Artisan torische afake IOL. De andere patiënt leed aan een resterend myoop astigmatisme en contactlensintolerantie na bilaterale RK. Wij behandelden haar door het implanteren van een Artisan torische pIOL in beide ogen. Beide gevallen resulteerden in een goede uitkomst.

In hoofdstuk 9 wordt een complicatie na en de gevolgen van een implantatie van een opvouwbare pIOL beschreven in een individuele patiënt. Het oog van deze patiënt leed aan recidiverende intraoculaire ontstekingen na myope Artiflex pIOL implantatie. De patiënt ontwikkelde ernstige celdeposities 1 week na de ingreep. Negen maanden later waren er nog vele celdeposities zichtbaar op de achterzijde van de lens, die leidden tot invaliderende glare klachten. Ondanks medische behandeling, moest de Artiflex lens uiteindelijk worden uitgewisseld voor een polymethyl methacrylaat (PMMA) Artisan pIOL. De lenswissel resulteerde in een postoperatieve ongecorrigeerde visus van 1.0 en het verdwijnen van de glare klachten. Het belang bij pIOLs ligt voornamelijk bij de lange termijn tolerantie van de lens. Deze moet voor de opvouwbare Artiflex lens nog worden aangetoond.

Tenslotte, beschrijft hoofdstuk 10 de verschillen tussen 2 iris-gefixeerde pIOL modellen: een niet-opvouwbare PMMA Artisan pIOL en een recentelijk ontworpen opvouwbare Artiflex pIOL. Het hoofdstuk analyseerde de veranderingen in optische aberraties voor de correctie van myopie, wat van belang is bij het volledige begrip van refractieafwijkingen, vooral in relatie tot ogen met hogere myopie en/of astigmatisme waarden. In de Artiflex groep van 27 ogen, daalden trefoil-y en SA significant. In de Artisan groep van 22 ogen, namen trefoil-y en SA significant toe. Laboratorisch onderzoek van de beide lenzen toonde dat de Artisan lens positieve SA heeft en de Artiflex lens negatieve SA, hetgeen de klinische bevindingen ondersteunt dat de Artiflex lens minder SA induceerde na de ingreep. Dit verschil in SA profiel kan mogelijk worden verklaard door verschillen in lens materiaal en/of lens ontwerp. 
Dankwoord \& Curriculum vitae 


\section{DANKWOORD}

De voltooiing van dit proefschrift is tot stand gekomen dankzij de hulp van anderen. Hier wil ik graag bij stil staan.

Allereerst wil ik mijn promotor Prof. Hendrikse bedanken, die dit alles mogelijk heeft gemaakt. U heeft vanaf het eerste moment vertrouwen in mij gehad, iets wat begon met mijn tijd in San Antonio. De opleidingstijd onder uw begeleiding was zeer leerzaam en al snel merkte $u$ mijn interesse in cornea en refractiechirurgie op. Ik ben u en Astrid Hacking zeer dankbaar voor alles wat u voor mij mogelijk heeft gemaakt, de afgelopen jaren.

Mijn co-promotor, Rudy Nuijts: het begon allemaal toen jij tijdens een druk arts-assistenten spreekuur in 2003 "even tussendoor" vroeg of ik interesse had om te promoveren. Ik wil je bedanken voor de bijzondere begeleiding die ik van je heb mogen ontvangen, ondanks je zeer drukke schema, en de mogelijkheden die je voor me hebt gecreëerd. Ik ben nog vaak verbaasd over wat je me hebt helpen bereiken. Ook wil ik je bedanken voor je vertrouwen door me te willen opleiden als cornea specialist.

De leden van de leescommissie, Prof. van de Borne, Dr. Budo, Prof. Luyten, Prof. van Rij en Dr. Webers wil ik bedanken voor het lezen en beoordelen van mijn proefschrift.

Heel veel dank en waardering wil ik uiten aan alle stafleden, arts-assistenten, paramedici, polikliniek medewerkers, secretaresses, operatiekamer medewerkers en onderzoekers van de afdeling oogheelkunde in het academisch ziekenhuis Maastricht, Medisch Centrum Maastricht Annadal, Atrium Medisch Centrum Heerlen en Brunssum. Met name veel dank aan Sara Schneider, Fleur Goezinne en Niels de Vries. Fred Eggink en Sander Bootsma wil ik bedanken voor hun mede-auteurschap. Albert Liem, bedankt voor je mental coaching. Ellen Vrancken en Marian Jansen wil ik bedanken voor hun administratieve ondersteuning. Tos Berendschot en Jan Schouten ben ik dankbaar voor hun statistische hulp.

Veel dank aan mijn studievriendinnen Marianne, Monique, Suzanne, Zita en met name Marijke, die dit proces jarenlang hebben gevolgd. Samantha en Anneke, mijn trouwe vriendinnen sinds onze eerste middelbare schooldag: bedankt! Anke, thank you for our great friendship since our Texas time. 007, bedankt voor de gesprekken die me door de laatste fase van mijn promotie hebben geholpen.

Mijn paranimfen Anneke en Yanny wil ik bedanken voor hun goede hulp en ideeën bij de eindfase. 
En dan het belangrijkste, mijn familie. Mijn zussen en broer Bahia, Muni, Sharon, Abbas en hun partners en kinderen wil ik bedanken voor hun jarenlange steun. Ook dank aan mijn tante en oom.

This book is for my mother and father, whom I love dearly. The completion of this book would have been impossible without your constant encouragement, guidance and love. Dad, I miss you...

This book is dedicated to my nephew Max, who has been a great source of inspiration and a true example of perseverance. 


\section{CURRICULUM VITAE}

De auteur van dit proefschrift werd geboren op 31 oktober 1974 te Utrecht als Nayyirih Grace Tahzib. Na het behalen van het examen Atheneum-B aan de Rijksscholengemeenschap Schoonoord te Zeist in 1993, ging zij geneeskunde studeren aan de Universiteit Utrecht. In 2000 behaalde zij haar artsendiploma, waarna zij naar San Antonio, Texas in de Verenigde Staten verhuisde om, in samenwerking met de afdeling oogheelkunde van het academisch ziekenhuis Maastricht, wetenschappelijk onderzoek te verrichtten gedurende 2 jaar. Hierna startte zij aan met haar opleiding tot oogarts (onder leiding van Prof. Hendrikse), welke zij in 2007 afrondde. Begin 2004 begon zij met haar promotie-onderzoek. Sinds het afronden van haar oogartsen opleiding werkt zij als oogarts en cornea fellow in Maastricht, Heerlen en Brunssum, onder leiding van Prof. Hendrikse en Dr. Nuijts. 